\title{
A Experiência de Fauzi \\ Dramaturgia em Processo
}

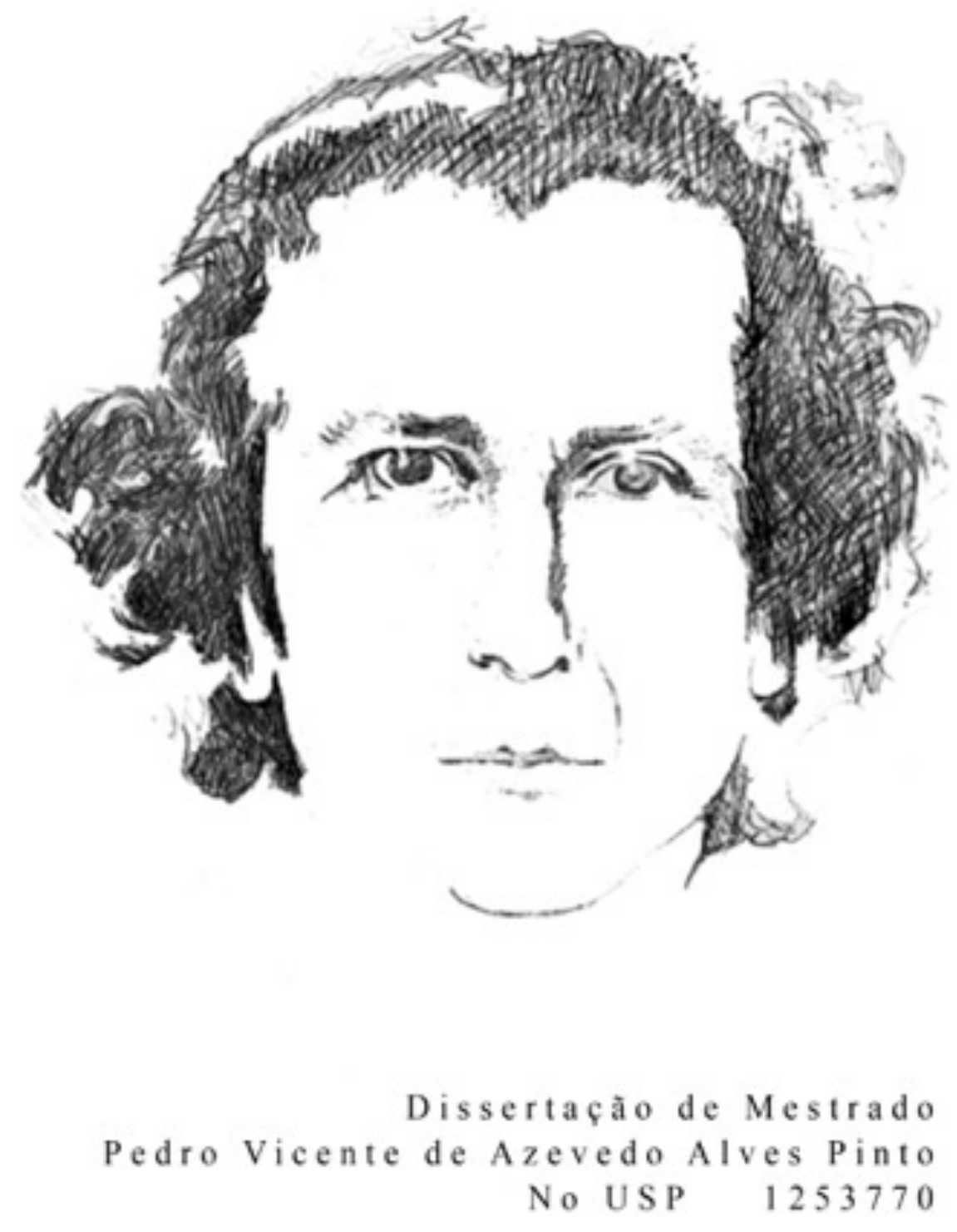

UNIVERSIDADE DE SÃO PAULO 


\section{ESCOLA DE COMUNICAÇÕES E ARTES}

PEDRO VICENTE DE AZEVEDO ALVES PINTO

A EXPERIÊNCIA DE FAUZI

Dramaturgia em processo

Dissertação apresentada à Escola de Comunicações e Artes da Universidade de São Paulo para a obtenção do título de Mestre em Artes Cênicas.

Área: Teoria e Prática do Teatro

Orientadora: Profa. Dra. Silvia Fernandes da Silva Telesi

SÃO PAULO 
Autorizo a reprodução e divulgação total ou parcial deste trabalho, por qualquer meio convencional ou eletrônico, para fins de estudo e pesquisa, desde que citada a fonte.

Catalogação na Publicação

Serviço de Biblioteca e Documentação

Escola de Comunicações e Artes da Universidade de São Paulo

Dados inseridos pelo autor

PINTO, PEDRO VICENTE DE AZEVEDO ALVES

A EXPERIÊNCIA DE FAUZI: Dramaturgia em processo /

PEDRO VICENTE DE AZEVEDO ALVES PINTO ;

orientadora, Silvia Fernandes da Silva Telesi.

-- São Paulo, 2018.

161 p.: il.

Dissertação (Mestrado) - Programa de Pós-Graduação em Artes Cênicas - Escola de Comunicações e Artes /

Universidade de São Paulo.

Bibliografia

Versão original

1. Alquimia do teatro 2. Teatro Brasileiro 3.

Contracultura 4. Fauzi Arap 5. Psicoterapia I. Telesi, Silvia Fernandes da Silva II. Título.

CDD 21.ed. - 792

Elaborado por Sarah Lorenzon Ferreira - CRB-8/6888 


\section{DEDICATÓRIA}

Dedico esta dissertação a: meus filhos Davi Puga Alves Pinto e Theo Vicente Prudente de Moraes Alves Pinto, que me acompanham na paixão pelo teatro; minha amada Yasna Yañez pela companhia preciosa durante o estudo; os artistas Ciça e Zélio Alves Pinto, que me deram a vida e muito mais; meus ancestrais indígenas, brancos, negros e alienígenas; meus irmãos de existência nessa realidade incerta; e o desejo vivo de um tempo de paz no coração do mundo. 
AGRADECIMENTOS

Agradeço a:

Aimar Labaki

Ana Céres

Ana Ciça

Andrea Cassola

Antônio Pinto

Antônio Fagundes

Antônio Malavoglia

Antônio Peticov

Bha Prince

Camila Mota

Carlos Cabrera

Carol Badra

Carol Bezerra

Carolina Ceres

Cecilia Alves Pinto

Cibele Forjaz

Clarice Abujamra

Claudia Schapira

Clélia Almeida

Daniel Lang

Daniela Thomas

Davi Alves Pinto

Débora Duboc

Eliana Camargo

Elisabeth Silva Lopes

Élcio Nogueira

Ester Laccava

Eugênio Lima

Exu Carangola

Fábio Atui

Fauzi Arap

Fernanda Couto

Fernando Alves Pinto

Fernando Cavalher

Gerald Thomas

Glauco Vilas Boas

Graziela Moretto

Guga Stroeter

Guilherme Leme

Hector Othon

Humberto Gentil

Igor Maroti Dumont

Inês Cardoso

Jaqueline Obrigon 
Jeyne Stackflett

Johana Albuquerque

José Roberto Aguilar

Keren Ora

Kiko Vianello

Laís Bodansky

Lavínia Pannunzio

Leona Cavalli

Líbero Malavoglia

Luaa Gabanini

Luah Guimarães

Luciana Caruso

Luciana Domschk

Luis Fernando Ramos

Luiz Casado

Luiz Damasceno

Luiz Feres

Luiz Miranda

Marcelo Drummond

Marcelo Palotta

Márcia Abujamra

Marcos Bulhões

Maria Goretti Pedroso

Messias Macambira

Nilton Bicudo

Paschoal da Conceição

Paulo Faria

Regina França

Renata Duca

Renato Borghi

Ricardo Van Steen

Roberta Estrela D'Alva

Rubens Rewald

Sérgio de Carvalho

Sérgio Mamberti

Sérgio Roizemblit

Silvana Garcia

Silvia Fernades Telesi

Stuar Perryn

Tamara Elizabeth Cury Sciré

Tatiana Vesch

Theo Moraes

Valéria Carvalho

Vânia Terra

Yasna Yañez

Zé Celso Martinez Corrêa

Zélio Alves Pinto 


\section{RESUMO}

Investigação sobre a noção de "alquimia do teatro" a partir da leitura do livro autobiográfico Mare Nostrum - sonhos, viagens e outros caminhos, de Fauzi Arap, realizada como estudo para a criação de uma dramaturgia baseada no depoimento. À partir da narrativa, que contempla o envolvimento do artista numa psicoterapia experimental baseada no uso psiquiátrico do LSD, identifica-se um paralelo entre a trajetória do autor e a dinâmica do mito associado à arte teatral - o mito grego Dioniso - e se reflete sobre as circunstâncias em que se deu a criação de sua obra, com foco no período da contracultura histórica brasileira. Buscando delinear a noção sugerida no capítulo 20 do livro "o teatro da alquimia e a alquimia do teatro", discute-se a questão do "teatro ritual" e se resgata a qualidade alquímica do mito de Dioniso, esboçando-se a noção de uma "alquimia dionisíaca".

Palavras-chave:

Alquimia do teatro; teatro brasileiro; Contracultura; Fauzi Arap; psicoterapia; LSD. 


\begin{abstract}
Research on the notion of "theater alchemy" from reading the autobiographical book Mare Nostrum - dreams, travels and other ways, by Fauzi Arap, carried out as a study for the creation of a dramaturgy based on the testimony. From the narrative, which contemplates the artist's involvement in experimental psychotherapy based on the psychiatric use of LSD, a parallel is identified between the trajectory of the author and the dynamics of the myth associated with theatrical art - the Greek myth Dioniso - and is reflected on the circumstances in which the creation of his theatrical work took place, focusing on the period of Brazilian historical counterculture. Seeking to outline the notion suggested in Chapter 20 of the book "The Theater of Alchemy and the Alchemy of Theater," the question of "ritual theater" is discussed and the alchemical quality of the Dionysian myth is rescued, outlining the notion of a "Dionysian alchemy".
\end{abstract}

\title{
Keywords:
}

Alchemy of Theater; Brasilian Theater; Contraculture; Fauzi Arap; Psichotherapy; LSD. 


\section{SUMÁRIO}

Introdução.......................................................... 10

Capítulo 1 - O Barquinho .......................................20

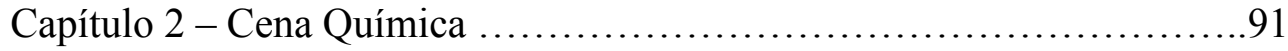

Capítulo 3 - Ofícina Alquímica ......................................102

Capítulo 4 - Teatro Nuvem.....................................131

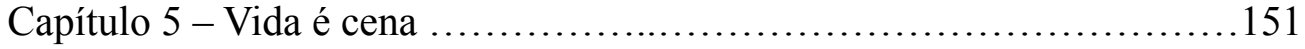

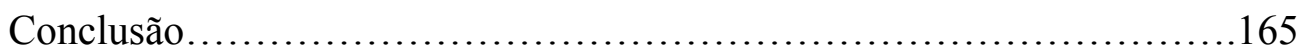

Referências...................................................... 171 


\section{INTRODUÇÃO}

Fauzi Arap foi um grande ator, diretor e dramaturgo brasileiro, nascido em São Paulo, onde viveu boa parte de seus 75 anos, entre 1938 e 2013. Formou-se em Engenharia Civil pela Faculdade Getúlio Vargas mas nunca exerceu a profissão. Estreou no ofício da cena aos 21, na primeira montagem profissional do grupo Teatro Oficina ${ }^{1}$, A Vida Impressa em Dollar, de Cliff Oddets², em 1959. A partir da década de 1960 foi figura marcante na cena teatral por mais de 5 décadas. Ator assíduo nos primeiros 7 anos do Oficina, ao mesmo tempo também atua junto ao grupo Teatro de Arena ${ }^{3}$ em montagens importantes, marcando um trânsito livre entre os dois mais significativos acontecimentos teatrais de uma geração germinal no cenário brasileiro. Com alguns êxitos e premiações como ator nos dois coletivos e outros trabalhos, em 1965 Fauzi estreia como diretor, numa adaptação pioneira da literatura da escritora Clarice Lispector, na peça "Perto do Coração Selvagem”, com Glauce Rocha, Dirce Migliaccio, José Wilker e o próprio diretor. Depois disso, em pouco tempo abandona o ofício de ator, com poucas exceções nos dois anos seguintes. Duas no cinema, em 1966, nos filmes "Todas as Mulheres do Mundo" de Domingos Oliveira e "O Padre e a Moça", de Joaquim Pedro de Andrade; e uma no teatro, em 1967, em sua segunda direção profissional, a peça Dois Perdidos numa Noite Suja, do então quase desconhecido autor Plínio Marcos. Fauzi dirige e interpreta a peça ao lado do ator Nelson Xavier.

\footnotetext{
${ }^{1}$ O Teatro Oficina Uzyna Uzona, ou Teatro Oficina, é uma companhia com sede em São Paulo. Fundada por alunos da Faculdade de Direito da USP em 1958, Amir Haddad, Renato Borghi, Fernando Peixoto, Ítala Nandi, Etty Fraser, e outros, com José Celso Martinez Correa como diretor, ou produtor, dramaturgo, agente cultural. Desde a reabertura da sede em 1993, a coordenação da companhia tem parceria do ator Marcelo Drummond. Nas 6 décadas de atividade, o Oficina tem várias fases. O início é de excelência estética e política em montagens realistas; 1967 é o encontro da identidade antropofágica com a montagem $O$ Rei da Vela, de Oswald de Andrade; nos anos seguintes, o teatro agressivo e o protagonismo do coletivo representado pelo Coro, marcado por Roda Viva, de Chico Buarque, remontada em 2018; nos anos de chumbo, o silêncio estrela a experiência cênica do Te-ato; à partir de 1980, o grupo desenvolve o gênero Tragicomediaorgia Antropofágica, que estreia em Hamlet, 1994, se define em As Bacantes, 1996; e frutifica em produções posteriores como a monumental Os Sertões, de Euclides da Cunha, 2003/2010,

${ }^{2}$ Cliff Odets (1906 / 1963) dramaturgo, diretor de teatro (e cinema em dois filmes), roteirista e ator norte-americano.

${ }^{3}$ Teatro de Arena (1953 /1972) foi um dos mais importantes grupos teatrais brasileiros das décadas de 1950 / 60 . Fundado em 1953 por José Renato e egressos da Escola de Arte Dramática da Universidade de São Paulo, estreia com a peça "Esta Noite é Nossa" de Stafford Dickens, com encenação inovadora no centro de uma arena improvisada numa sala do MAM/SP - Museu de arte Moderna de São Paulo. Em 1956 o grupo se funde ao o Teatro Paulista dos Estudantes, de Gianfrancesco Guarnieri, Oduvaldo Viana Filho, Milton Gonçalves e outros, e incorpora o diretor Augusto Boal como professor do método Stanislavski. Em 1958, a peça Eles não Usam Black Tie, de Guarnieri, direção de José Renato, marca as artes cênicas brasileiras. O golpe militar de 1964 leva à proibição da maioria de suas peças de viés realista, e em 1965 estreia "Arena conta Zumbi", de Boal e Guarnieri, novo marco da arte cênica; em 1971 Boal dirige Teatro Jornal - $1^{a}$ Edição, de Boal, trabalho que abre caminhos para a criação posterior do seu método Teatro do Oprimido. No mesmo ano, Boal é preso e exilado. Em 1972 o grupo termina.
} 
No mesmo ano de 1967, Fauzidirige a peça Santidade, texto transgressor do autor quase estreante, José Vicente ${ }^{4}$, e acaba criando um momento símbolo da contracultura, uma performance midiática espontânea, quando a peça é censurada antes da estreia e o presidente Costa e Silva condena a obra em rede nacional de televisão.

No ano seguinte, Fauzi volta a Plinio Marcos em parceria com Tônia Carrero $^{5}$ em montagem histórica do texto "Navalha na Carne":

No Rio, naquele mesmo ano, acabei por fazer minha estréia definitiva como diretor profíssional na versão carioca de Navalha na came, na produção de Tonia Carrero, e dirigi também meu primeiro show com Maria Bethânia, com quem desenvolvo uma parceria afinada até hoje. (ARAP, 1998, p.98)

Em 1971, dirige o show "Rosa dos Ventos"6 que projeta nacionalmente o nome da cantora Maria Bethânia. Em 1975 dirige a própria estréia como dramaturgo com a peça "Pano de Boca", visão poética da cena brasileira nos anos 1960 e 1970, primeiro de 16 textos de sua autoria, encenados sob sua direção.

Ator, diretor ou autor, Fauzi recebe alguns prêmios Molière, Shell e APCA, e desenvolve uma obra potente e original. Efêmera, como todo teatro, com excessão dos 16 textos encenados, eternizados na publicação de sua dramaturgia completa em 2015 (SESI SP Editora). Mas seminal, e fundamentalmente registrada no livro de memórias Mare Nostrum, sonhos, viagens e outros caminhos" (SENAC, 1998), que constitui fonte e inspiração principal desta investigação.

Em 1997, 30 anos depois da montagem original, Fauzi finalmente estréia Santidade, com produção de Sérgio Mamberti, no extinto Teatro Crown Plaza, teatro pequeno num subsolo na Rua Frei Caneca, em São Paulo. No prefacio do Mare Nostrum, o dramaturgo

\footnotetext{
${ }^{4}$ José Vicente: (1945 / 2007) Dramaturgo brasileiro com a obra ligado aos anos 1960 e 1970, escreve sobre a rebeldia e poesia intrínsecas à geração da contracultura histórica. Formado em Filosofia pela USP, publica o livro, "os Reis da Terra" (Nova Fronteira), com grande repercussão. Entre 1967 e 2004 tem quinze peças encenadas.

5 Tonia Carreiro (1922 / 2018) Maria Antonieta de Farias Portocarrero nascida e crescida na zona sul carioca, atua em filmes da Companhia Cinematográfica Vera Cruz e estreia no teatro no Teatro Brasileiro de Comédia (TBC), em São Paulo, na peça Um Deus Dormiu Lá em Casa, atuando junto ao ator Paulo Autran. Ainda nos aos 1950 forma com o então marido, Adolfo Celi, e Paulo Autran, a Companhia Tônia-Celi-Autran (CTCA), que nos anos 1950 e 1960 revoluciona com um repertório que combina clássicos e vanguarda.

${ }^{6}$ Rosa dos Ventos (1971) O show encantado - foi chamado o espetáculo premiadíssimo que fez história como acontecimento definidor na década de 70. Mais célebre entre vários shows de Maria Bethânia com direção de Fauzi Arap, o cenógrafo e figurinista Flávio Império e os músicos do Terra Trio. Com roteiro e arte inspirada no universo da alquimia, cantava a volta dos exilados, incluindo Caetano Veloso e Gilberto Gil, e mesclava às canções textos de Fernando Pessoa e Clarice Lispector.
} 
Aimar Labaki ${ }^{7}$ registra "sucesso absoluto" de crítica, com vários prêmios para texto e direção, que reacenderia a "experiência radical de um teatro mínimo em que apenas um texto poético e três atores dão conta de dialogar com [a] iluminação pessoal, e sua inevitável relação com o coletivo". Ao mesmo tempo, literalmente, o artista ocupava, vitoriosamente, o exato oposto "do espectro teatral" com outra peça em cartaz, Caixa 2, de Juca de Oliveira, "maior bilheteria do ano, espetáculo comercial, com produção e estéticas alinhadas com os parâmetros da indústria de entretenimento." (LABAKI, 1998 apud ARAP, 1998, p.12) A proeza de ocupar simultaneamente extremos opostos e marcantes da cena teatral - sucesso de crítica numa obra radical e sem concessões, e sucesso de público numa peça de com fins lucrativos - não impediu que Fauzi fosse definido naquele final de milênio como "o mais desconhecido dos grandes artistas brasileiros" (IDEM). Talvez porque no final dos anos 1990 o teatro já não fizesse mais a fama de "grandes artistas" tanto quanto a televisão, na qual Fauzi nunca trabalhou, ou a música popular daqueles dias. Ou talvez porque parte do público o via apenas como um diretor ligado a um velho "teatrão" sem novidades, no qual se encaixa o sucesso de Caixa 2, ignorando a trajetória e outras dimensões do artista reveladas em seu livro de memórias. Este estudo situa Fauzi como um criador à altura da grandeza e da gravidade de seu tempo, especialmente ao tempo de seu florescimento como artista, quando os porões da ditadura assombravam uma revolução de costumes movida a sexo, drogas e rocknroll. Vanguarda numa geração áurea da cultura brasileira, fez história nos palcos, e nos bastidores mirou decifrar o inconsciente como pesquisador autodidata da psicologia analítica. Estudou Carl Gustav Jung ${ }^{8}$, trabalhou com Nise da Silveira ${ }^{9}$, flertou com a loucura, testou seus estudos no palco, driblou limites entre arte e psicologia, com sensibilidade, e transformou tudo em

\footnotetext{
${ }^{7}$ Aimar Labaki, dramaturgo, diretor, roteirista, ensaísta, crítico e tradutor paulistano.

${ }^{8}$ Carl Gustav Jung (1875 / 1961) médico psiquiatra, psicoterapeuta, pesquisador e autor suíço, fundador da Psicologia Analítica, ramo da psicologia que tem como conceito central o processo da individuação, ligado à integração dos opostos psicológicos. Criador de conceitos psicológicos como os de: "arquétipo", "inconsciente coletivo", "complexo", "sincronicidade", e personalidade "extrovertida e introvertida". Estudioso maior de análise de sonhos, explorou áreas tangenciais à ciência, como filosofia, alquimia, astrologia e sociologia, literatura e arte. Sua obra segue fortemente influente na psiquiatria, psicologia, ciência da religião, literatura etc.

${ }^{9}$ Nise da Silveira (Maceió, 1905 / Rio de Janeiro 1999) Médica psiquiatra brasileira, foi aluna de Carl Gustav Jung e responsável pela introdução inicial e divulgação da psicologia junguiana no Brasil. Autora de vários livros sobre psicologia e psiquiatria, na prática clínica combate as técnicas de tratamentos da época: confinamento em hospitais psiquiátricos, eletrochoque, insulinoterapia e lobotomia. É presa como comunista no mesmo presídio que Graciliano Ramos, e seu encontro é registrado no livro Memórias do Cárcere. Funda o Museu de Imagens do Inconsciente, centro de estudo e pesquisa da arte ligada à manifestação do inconsciente, dedicado à preservação das obras visuais produzidas nos estúdios que coordenou em sua instituição.
} 
teatro. Causou impacto com sua perspectiva e deixou sua verve guardada viva nas linhas e entrelinhas de seu texto.

Mare Nostrum conta uma história pessoal, no contexto da contracultura histórica brasileira; ao mesmo tempo, uma história universal, sobre um artista tocado pela dimensão sagrada do ofício da arte. Refletindo sobre sua trajetória no teatro e na vida em geral como artista, Fauzi resgata encontros com personagens significativos da cena cultural brasileira dos anos 1960 e 1970, e ilumina questões importantes do universo teatral e do momento histórico, incluindo, de forma germinal, a própria experiência pioneira, no começo do ano de 1963, como paciente de uma psicoterapia experimental à base de Delysid LSD25, medicamento produzido e distribuído pela multinacional Sandoz, original do genérico "acido lisérgico" que se popularizou no final da década de 1960; uma história com potencial para virar teatro, dramaturgia, uma peça, talvez um filme, uma ficção biográfica. Mas antes, o depoimento instiga uma investigação sobre os aspectos profundos que o possibilitam e o contextualizam: a contracultura histórica brasileira, no qual Fauzi foi um dos protagonistas; as influências que acompanharam suas escolhas: Jung, Antonin Artaud, Clarice Lispector e outros; os parceiros e colegas e suas trajetórias. Uma investigação sobre a arte do teatro, inspirada em ideias lançadas no depoimento de um ator, diretor e autor, com sua expressão peculiar como criador original no contexto Brasileiro. Nessa expedição por um mar das possibilidades infinitas, as cartas náuticas são as páginas deste livro considerado pela crítica como um documento que resgata o estado da arte na raiz da efervescência artística dos anos 1960 e 1970 no Brasil, aqui adotado como fruto e fonte da mesma verve criativa que marcou a trajetória do autor.

Na orelha da edição, assinada por Maria Bethânia, a diva da MPB chama o livro do exparceiro e diretor de vários shows de "objeto sagrado". O entusiasmo é compartilhado pelo antropólogo, pesquisador e roteirista Hermano Vianna, numa coluna no jornal $O$ Globo em 20/12/2013, dias após a morte de Fauzi: “é um dos relatos mais comoventes, de entrega total, sobre a combinação de busca espiritual e desenvolvimento artístico. É também documento precioso sobre a aventura tempestuosa da cultura brasileira, dos anos 1960 até hoje." O antropólogo lembra o depoimento do artista sobre o show "Rosa dos Ventos", de Bethânia, 
dirigido por ele, com cenários de Flávio Império ${ }^{10}$ : "alguns acabaram presenteados com o livre acesso diário ao show, depois de terem voltado quarenta vezes" (ARAP, 1998, p. 153) O impacto do espetáculo fez dele um acontecimento quase histórico, de grande influência no ambiente cultural. Um tipo de impacto talvez impossível no caos do presente, mas em 1971, no Teatro da Praia, Copacabana, Rio de Janeiro, a direção de Fauzi somou com Bethânia e Império para expressar o espírito do tempo. O cheiro de sangue dos porões da ditadura estava no vento das revoluções comportamentais, e na lama dos anos de chumbo, a flor de lótus era uma geração de gênios da cultura nacional. No programa do show, Fauzi anuncia: “...Todos os mitos da história conheceram o òvo de vidro. Agora, o que há é que foi como que deflagrada uma epidemia de ressurreições..." (ARAP, 1971).

Essas palavras do diretor impressas no programa do show Rosa dos Ventos fluem num estilo que resume uma visão de mundo ligada ao espírito daquele tempo: "paz e amor" de um lado, "apesar de você" do outro, "tudo é perigoso, divino e maravilhoso" na veia. Um estilo transgressor inclusive pela sinceridade de um sentimento puro de paz e amor, e pela nostalgia de um presente tocado pelo assombro, do terror político à revolução dos costumes, com todo florescimento envolvido. Isso e ainda outras coisas, como disse Jean Cocteau em seu Le Secret Profissionnel, o estilo é uma maneira simples de dizer coisas complicadas. Às vezes, necessárias. Como talvez seja o caso na abordagem deste Mare Nostrum. Confiando nesta hipótese, este estudo se declara desde o início digitado na lógica do prazer, começando por tomar como referência de estilo o discurso do diretor no programa do show de sua diva.

Naqueles dias, a polícia política matava e torturava, reagindo à guerrilha e reprimindo brutalmente a oposição. E a liberdade dava um jeito pelas frestas, iluminando a revolução de costumes pelo "poder das flores". E aqui se fala das flores de Perséfone11, servidas nos ritos

\footnotetext{
${ }^{10}$ Flávio Império (1935 / 1985) Cenógrafo, arquiteto, professor de urbanismo e artista plástico, considerado um dos melhores cenógrafos do teatro brasileiro. Participou do Teatro de Arena junto com Gianfrancesco Guarnieri e Augusto Boal. Ganhou destaque no meio teatral paulistano em 1959 quando concebeu os cenários e figurinos da peça Morte e vida severina para o Teatro Experimental Cacilda Becker. Trabalhou também no Teatro Oficina com José Celso Martinez Correa. Criou cenografias importantes no Teatro de Arena, além de criar cenários para grandes shows musicais exibidos em São Paulo na década de 1970 como "Pássaro da Manhã" ou"Rosa dos ventos" com Maria Bethânia, e "Doces Bárbaros" com Caetano Veloso, Gal Costa, Gilberto Gil e Maria Bethânia.

${ }^{11}$ Perséfone - Deusa do submundo na mitologia grega, Deusa da Primavera, Deusa Invernal, Rainha do Submundo Deusa da Agricultura, das estações, das flores, dos frutos, das ervas e da fertilidade. Sua flor preferida é o Narciso de Cem Cabeças, a flor alucinógena que dá nome aos narcóticos. Na mitologia romana, é chamada Proserpina.
} 
de Eleusis ${ }^{12}$, falamos sobre isso num capítulo adiante. Por isso era natural a sintonia entre o espírito do tempo e a inspiração profunda quase ingênua no texto do programa. O impacto do show Rosa dos Ventos mostra o quanto Fauzi foi um dos alquimistas de uma cena especial no quadro da cultura brasileira, e seu Mare Nostrum revela pistas sobre esta alquimia, que interessam a esta investigação.

Dentro do depoimento, o que inspira e concentra o interesse dessa conversa é principalmente o capítulo 20, nomeado $O$ teatro da alquimia e a alquimia do teatro. Basicamente, narra um incidente ocorrido durante a montagem da peça Um Ponto de Luz (o segundo texto de Fauzi, dirigido por ele mesmo em 1977) quando o conteúdo da cena se refletiu de forma surpreendente na vida pessoal da equipe, elenco e direção, em acontecimentos que puseram à prova a tese conceitual da dramaturgia encenada. Diante de uma dinâmica de forças evidente, mesmo sem causalidade concreta, Fauzi identifica um episódio de impacto intangível porém efetivo da arte da encenação sobre os envolvidos com a cena. A partir daí, reflete sobre o que nomeia alquimia do teatro: "Maldição ou bendição, quem adivinha a alquimia inerente a arte da representação não pode nunca mais repousar a superfície" (ARAP, 1998, p. 234)

Fauzi não entra em analogias específicas com a alquimia tradicional ou procedimentos alquímicos, mas escreve: "Meu livro de cabeceira, na época, era Psicologia e Alquimia de Jung" (ARAP, 1998, pg. 144), assim indica o pano de fundo teórico para os questionamentos e escolhas que figuram o depoimento. O suíço Carl Gustav Jung foi um pesquisador que buscou aprimorar seus recursos clínicos a partir da constatação da analogia entre os processos descritos na literatura alquímica e os processos subjacentes a toda atividade psíquica, que ele entendia animada por uma pulsão evolutiva pela integração dos opostos. Nos registros da busca do ouro alquímico, decifrou reflexos do inconsciente coletivo no curso do aperfeiçoamento da matéria viva consciente, e este material decifrado compõe um vasto vocabulário de símbolos e imagens coletivas e particulares, que se reinventam como camaleões em cada consciência. A proeza de Jung foi ser drasticamente científico, empírico e sistemático nesse campo essencialmente volátil. A proeza de Fauzi foi ser drasticamente

\footnotetext{
${ }^{12}$ Eleusis era uma pequena cidade próxima a Atenas, numa região rica em cevada e trigo, onde se localizava o templo de Deméter, Deusa da Agricultura, onde se realizavam rituais de adoração aos Deuses, principalmente "as duas deusas de Eleusis", Deméter e sua filha Perséfone, também chamados Mistérios de Eleusis, pois era proibido por morte falar sobre a experiência depois de vivida. Eram rituais de morte e renascimento, que simbolizavam a descida necessária da consciência ao mundo da morte para que a vida voltasse a florescer na Primavera.
} 
pessoal, e tão literal quanto literário ao discorrer sobre temas de alcance transcendental. Sem arriscar conclusões que não caberiam numa crônica de memórias, mas com perspectiva apaixonante, o testemunho, no todo, sugere um conceito, abre janelas para o desconhecido e aponta um campo de investigação sobre uma certa relação entre Teatro e Alquimia.

Toda escolha dos caminhos para essa investigação segue os fios de Ariadne deixados pelo artista, recolhidos principalmente entre as linhas e entrelinhas do seu Mare Nostrum. A começar pelo discurso inconclusivo e questionador que permeia o texto, numa primeira pessoa sem pretensão que revela a universalidade que se reconhece como ponto de vista, uma forma particular de organizar as ideias. Um depoimento, no máximo, uma narrativa reflexiva com viés literário, sem aspiração científica. É nessa liberdade que Fauzi avança pelo campo das ideias que não cabem em palavras, construindo as trilhas que conduzem esta investigação.

A alquimia a ser estudada é a alquimia do teatro a partir de Fauzi Arap. Aquela sugerida em seus relatos e reflexões sobre os fenômenos de sua lida teatral à luz de seus estudos no campo da psique humana, que ele relaciona à alquimia, mas deixa ao leitor a tarefa de imaginar, mais especificamente, o que uma coisa tem a ver com a outra. Fauzi fala sobre a Alquimia estudada por Jung, entendida como metáfora para o processo de cura psíquica proposto pela psicologia analítica, cujo estudo dá acesso a conteúdos inconscientes, possibilitando a operação do processo da cura psíquica. Algo análogo a uma criptografia reversa aplicada na decodificação da linguagem do inconsciente e que Fauzi percebe aplicável na dinâmica teatral, talvez buscando operar ativamente a "alquimia inerente a arte da representação" que ele adivinhou e por isso nunca mais quis "repousar a superfície".

Esta aplicação que Jung encontrou para a metáfora alquímica se dá a partir da descoberta de que os registros do fenômeno psico-histórico podem funcionar como esquema de observação das dinâmicas da psique, e nesse sentido inspira este estudo. É uma aplicação científica incomum, já que a metáfora, alquímica ou não, é uma figura de linguagem, um recurso estilístico ligado à poesia. Ao gênero literário, tanto quanto um estado de coisas, uma sensação, inspiração, a elevação das ideias, o que desperta o sentimento do belo, além de não ser uma descrição exata, mas uma associação de ideias, um recurso que normalmente esculpe qualquer mensagem na nuvem da subjetividade. Talvez por isso capaz de ser mais precisa na comunicação do incomunicável, mesmo guardando relação especial com o método científico. 
Segundo o filósofo e linguista búlgaro Tzvetan Todorov ${ }^{13}$, no livro "As Estruturas Narrativas":

não existe ciência (...) livre de toda subjetividade. (...) O economista, o antropólogo, o lingüista (...) são conscientes disso e tentam circunscrever essa subjetividade e levá-la em conta no interior da teoria. Não tentaremos pois repudiar a subjetividade das ciências. (TODOROV, 2006, p.81)

E se a economia, a antropologia e a linguística devem integrar a subjetividade, o teatro tem nela uma ferramenta principal, porque existe essencialmente a partir da presença física de seres humanos feitos de carne, osso e subjetividades. Também na plateia, mas principalmente no palco, essa presença é o coração da arte. Se o sangue que esse coração bombeia atinge a dimensão textual do teatro, pode ser um convite à teoria e à dramaturgia para a aplicação, fora do corpo, da subjetividade, de formas objetivas, como da objetividade, de formas subjetivas. Como seria uma "Alquimia do Teatro" aplicada, talvez não só no fazer teatral, mas no pensamento.

Em si, a alquimia é um campo de conhecimento essencialmente hermético, e talvez por isso Fauzi só chama o nome, "cita a fonte", e não entra no assunto, mas lança a isca criativa que esse texto morde, querendo subir no ombro do gigante e encontrando outros que já subiram, e trouxeram as grandes perspectivas sistematizadas, prontas para a ampliação em novas perspectivas.

Fauzi parece sugerir que a mesma dinâmica de simbiose entre símbolo e realidade verificada por Jung nos devires da psique ocorre nos processos teatrais, na criação das cenas e personagens. Seria a mesma lógica da aplicação dos mitos, pelos psicólogos, para identificar os arquétipos em jogo e organizar os conteúdos esquivos da psique, mas no sentido inverso, não diagnóstico, mas propositivo.

Assim, o uso psicológico do imaginário alquímico como chave reversa para compreensão e operação de processos psicológicos, análogo ao uso do mito para o mesmo propósito, é o modelo de abordagem para este estudo. O rastro do depoimento de Fauzi deixa território livre para a metáfora como ferramenta para apreensão de conteúdos esquivos ao

\footnotetext{
13 Tzvetan Todorov (1939 / 2017) Filósofo, linguista e teórico literário. Nascido em Sófia, Bulgária, radicou-se em Paris a partir dos anos 60. Foi aluno de Roland Barthes. Fundou a revista "Poetique" com Gérard Genette. Produziu uma obra vasta na área de pesquisa linguística e teoria literária, com a publicaçãode um número considerável de obras, hoje traduzidas em vinte e cinco idiomas, inclusive Português.
} 
olhar direto. Como aqueles disponíveis a um exame da trajetória que se revela no depoimento de Fauzi e suas sugestões sobre a Alquimia do Teatro.

A tradição oral, originalmente ligada à linguagem do mito, se confirma como caminho certeiro no curso desta investigação pela dinâmica espontânea do próprio estudo e sofre uma injeção de vitalidade a partir das conversas com ex-parceiros e outros artistas relacionados. Conversas grávidas de caminhos criativos que lançaram fios condutores para a reflexão, remetendo ao pensamento de Fauzi e outros autores, ligando a teoria à prática e criando uma reflexão aberta e improvisada sobre o que seria a "alquimia do teatro". O formato do diálogo se revelou justo, inspirou caminhos e questões, finalmente sugerindo a dramaturgia em processo como forma ideal para o encadeamento desta pesquisa e reflexão . A experiência de Fauzi é o objeto de estudo desta investigação, é também o modelo de procedimento, e finalmente é o nome de uma dramaturgia em processo sobre A Experiência de Fauzi.

O primeiro capítulo $O$ Barquinho examina uma questão-chave no Mare Nostrum relativa à comunicação do incomunicável: algo universal, matéria prima de toda arte, ao mesmo tempo específico, uma questão do Fauzi com o impacto da terapia do LSD sobre sua sensibilidade artística. Define-se a escolha do mythos para a abordagem adequada e observase os primeiros anos da carreira do ator e o percurso do artista da estreia como diretor até a estreia como dramaturgo. Inclui trechos de entrevistas com o diretor do Teatro Oficina, Zé Celso Martinez Corrêa e com o ator e produtor Sérgio Mamberti. O segundo capítulo, Desafio, analisa as implicações do relato contido no Capítulo 20, O teatro da alquimia e a alquimia do teatro, no qual Fauzi narra o incidente na montagem da peça Um Ponto de Luz, à luz das próprias suspeitas sobre a ação intangível e dos conteúdos encenados na vida dos envolvidos. Além do caso de paralelismo entre cena e vida apontado no Capítulo 20, há um paralelo entre o enredo da mesma peça e a própria trajetória do Fauzi, que não é mencionado no capítulo, mas é contundente, e traz perspectivas reveladoras sobre sua trajetória. O terceiro capítulo, Oficina Alquímica, reúne um conjunto de entrevistas que dialoga com as ideias de Fauzi e autores relacionados, numa experiência textual que parte da edição e organização criativa de entrevistas com artistas do grupo Teatro Oficina, Camila Motta, Luciana Domshcke, Paschoal da Conceição e Marcelo Drummond, sobre como a experiência de Fauzi ressoa em sua relação com a arte, somando ao estudo os depoimentos que dimensionam a influência do autor na cena teatral. O quarto capítulo, Teatro Nuvem, examina a relação entre a 
experiência de Fauzi e a ancestralidade do Teatro. O último capítulo, A Vida é Cena, é o argumento da dramaturgia em processo baseada no livro Mare Nostrum.

Examinamos o quanto da experiência de Fauzi reverberou nos parceiros diretos e outros artistas em contato com o trabalho dele até hoje e como sua visão ressoa ou se relaciona com a de outros pensadores do teatro e da psique. É possível decifrar um conceito de "alquimia do teatro"? Existe a influência transformadora dos signos encenados sobre a realidade dos encenadores? Existe alguma perspectiva de responder essas questões objetivamente? Algumas, sim, outras, subjetivamente, mas precisamente, ou poeticamente, considerando uma transmutação da experiência de Fauzi nessa dramaturgia em processo. 


\section{Capítulo 1}

\section{O BARQUINHO}

\section{Mare Nostrum}

Antes de tudo, observamos o título escolhido por Fauzi Arap para seu livro depoimento: Mare Nostrum, sonhos, viagens e outros caminhos. Na página 145, ele define a expressão latina como sinônimo de "Inconsciente Coletivo" nos termos da psicologia analítica de Carl Gustav Jung. Seria a camada mais profunda da psique, o reino dos arquétipos - as bases funcionais comuns a todo ser humano que resultariam num acervo do imaginário desde o início dos tempos, guardado no cérebro arcaico da espécie, a ancestralidade impressa no DNA humano, a eternidade no tempo de cada um. Para os românticos, o vínculo do homem com a natureza, fonte da genialidade, "berço último de nossas ideias, aquela região subterrânea que nos habita (...) Essa zona obscura é que deve ser explorada, pois ela é a zona original, raiz coincidente com o divino, verdade última e ponto de partida do homem" (BORNHEIM apud GINSBURG, 2005, p.82). Em suma, uma dimensão selvagem, e o título do depoimento faz justiça ao conteúdo. Por isso é importante observar que lidamos, ao longo do estudo, não somente com as palavras, ou com a ideia, mascom o próprio Mare Nostrum. O Inconsciente Coletivo, que incluiria o Inconsciente de cada um de nós, a parte da psique pessoal que contém a Totalidade. Uma instância psíquica que será sempre coletiva, envolvendo a todos como neblina que se intensifica, inquieta, quando se buscam suas portas.

A expressão surge dentro da narrativa no Capítulo 12, página 144, pela voz de um paciente psiquiátrico da Casa das Palmeiras, aluno de Fauzi nas aulas de teatro que este ministrou, entre 1970 e 1973, na clínica dirigida pela célebre doutora Nise da Silveira:

Havia nele uma certa arrogância, eu diria. Ele quase nunca falava, apenas sorria, superior a tudo. E quase sempre passeava solto pela casa, sem respeitar nem reuniões, nem horários (...) disseram que era muito inteligente. Algumas poucas vezes aparecia em minhas aulas, mas quase nunca participava diretamente, e muito menos falava ou se colocava. Mas naquele dia em que me referi às "águas interiores", fui surpreendido por sua resposta:

- É o Mare Nostrum... - disse. Duvidei do que tinha ouvido. Não era possível que ele tivesse se expressado em latim. (ARAP, 1998, p.144) 
$\mathrm{Na}$ época, segundo o depoimento, Fauzi não pôde senão imaginar por onde andava a psique de seu aluno para chegar àqueles termos. Precisou de mais alguns meses para começar a fazer sentido, e de mais trinta e poucos anos para saber o que fazer com aquelas palavras. $\mathrm{O}$ caminho proposto pelo artista, percorrido nas reflexões a seguir, evolui necessariamente por uma região instável, que pede atenção especial. Coletivo ou não, o Inconsciente é, por definição, feito daquilo que está fora da consciência. Quando a atenção se volta para o Inconsciente, a consciência fica, naturalmente, fora de si e começa a tatear no escuro. Mais do que isso, a neblina do Mare Nostrum envolve a todos que se aproximam, mesmo de longe, num ambiente potencialmente perturbador. O Inconsciente é domínio da psicologia analítica, ciência complexa que requer treinamento específico, entre outras coisas, para se lidar com as reações do Inconsciente às investidas da consciência, que provocam flutuações que desestabilizam o logos - a capacidade da consciência que inclui razão, linguagem e normatividade - tornando o discurso cartesiano inadequado para a apreensão da experiência. Pensamentos organizados em palavras escritas se transformam nas próprias mãos tateando no escuro. Outro tipo de abordagem se faz necessário.

O encontro da consciência com a inconsciência será sempre um paradoxo delicado, porque o que reside no inconsciente tem motivos sérios para estar excluído desta consciência. Motivos ligados à estrutura psíquica de cada um. Essa exclusão, em si, define a consciência. Para abordar o Inconsciente, a consciência trabalha na própria inexistência, como brincando de se diluir no ácido, ou se fragmenta, como num prisma, ou como um corpo celeste entrando na atmosfera. E quando se reestabelecem as conexões, surgem sintomas como bloqueios, emoções aleatórias ou perda da capacidade de cognição imediata. Como num choque de luz, os sensores precisam ajustar a sensibilidade para poder distinguir o ambiente. Às vezes, esse ajuste pode ser o trabalho de uma vida.

De fato, Fauzi levou três décadas e meia para chegar a escrever objetivamente sobre as experiências que descreve no Mare Nostrum, especialmente as aventuras psicológicas a partir de um processo terapêutico bombástico - com o uso pioneiro do LSD - no início da década de 1960, sob os cuidados médicos do psiquiatra Dr. Murilo Pereira Gomes ${ }^{14}$. Segundo o autor, o

\footnotetext{
${ }^{14}$ Murilo Pereira Gomes (19- / 1965) Médico psiquiatra atuante no eixo Rio São Paulo, pesquisou os efeitos e potenciais terapêuticos do LSD, publicou o artigo sobre o estudo em 1963 sob o título "Configuração de uma Psicoterapia com o Uso do LSD-25".
} 
nível impecável de coerência e sintaxe que se imprime em seu texto só foi possível graças a esta longa decantação.

Eu não sabia que aquelas experiências espantosas e intensas que eu vivera num curto espaço de tempo acabariam me consumindo quase 20 anos de reflexão e estudos para serem corretamente digeridas. Mas a relativa clareza com que hoje é possível falar sobre elas não se parece com a forma quase anárquica com que tudo acontecia. (ARAP, 1998, p.158)

A terapia foi o início de um mergulho radical nos estudos da Psique. Fauzi devorou bibliografias, se envolveu, cuidou de pessoas. Outras vezes só tentou cuidar. Pôs a mão na massa justamente trabalhando com Doutora Nise, integrando sua equipe como professor de teatro / terapeuta informal em sua clínica. Mesmo assim, só nos anos 1990 tomou seu tempo para publicar alguma coisa especificamente sobre o assunto. Talvez porque só a reflexão revisitada ao longo dos anos traria a multiplicidade de perspectivas que permite a compreensão objetiva de uma imagem grande demais. Certamente o tempo colaborou para que o livro seja um depoimento, tipo de discurso que se define, basicamente, como um testemunho pessoal e objetivo sobre experiências efetivamente vivenciadas. Não é ficção, não é um romance ou um poema, é um testemunho sincero, reservado, ao mesmo tempo visionário e autoquestionador, mas algo literário, uma crônica de memórias, um testemunho romanceado. Um discurso que resolve, na liberdade criativa e testemunhal, o impasse da inefabilidade dos temas que aborda. Inefabilidade que se revela, ao longo dos encontros e conexões de ideias alinhados nesta pesquisa, uma questão central na trajetória do artista.

\section{MYTHOS E LOGOS}

$\mathrm{O}$ antropólogo e historiador francês Jean-Pierre Vernant ${ }^{15}$ escreve em "Mito e Sociedade na Grécia antiga" sobre o logos em oposição ao mythos, a partir do uso da palavra escrita no século VIII a.C., que institui um novo paradigma de processamento e racionalização da realidade a partir da análise e ordenamento mais estrito da matéria conceitual. Chegando diretamente ao discernimento, sem distração, a palavra escrita demonstra a materialidade da mensagem e estabelece a ordem do verdadeiro e inteligível. Assim, o Logos ultrapassa a

\footnotetext{
15 Jean-Pierre Vernant_ - 1914 / 2007 - Historiador e antropólogo francês, especialista em Grécia Antiga e mitologia grega. Autor de inúmeras publicações sobre os temas, foi professor honorário do Collège de France. A partir de 1971 leciona por alguns anos no departamento de Filosofia da Universidade de São Paulo, que corria risco de extinção dado o número de professores exilados em função da Ditadura Militar. Afim de ajudar os colegas brasileiros e atrair maior atenção internacional à situação de exceção no Brasil, Vernant se tornou professor do departamento.
} 
palavra para ganhar valor de racionalidade; já o mythos vem da palavra falada e se perpetua na qualidade dessa origem, feita do encantamento vivo do prazer de quem ouve e a graça de quem fala, criando o entendimento na ordem do fascinante e do maravilhoso. A história é uma ciência do logos, aceita como verdadeira porque narra um tempo supostamente palpável, com registros de personagens e testemunhas. Já o mito fala de um passado tão distante que não sabemos mais como foi, era um mundo fantástico onde tudo pode ter acontecido. Nessa liberdade, o Inconsciente Coletivo escreve as fábulas e imagens que alcançam as dimensões da psique onde brincam as questões mais profundas.

A mesma liberdade que fertiliza o Inconsciente primordial na criação do mito, com sua função de ordenar na mente e no coração os fatos profundos da alma e da existência, também dá frutos profanos, como a literatura e a dramaturgia e suas variações ainda mais profanas, incluindo esta investigação, que também se filia à sintaxe da fala, na busca de um equilíbrio em que o Mythos opera no reino do Logos. Assim, neste começo de conversa, recomendamos que estas palavras sejam lidas como se fossem escutadas, honrando o passe livre conceitual da metáfora no contexto em que trabalhamos, já que o nome do livro Mare Nostrum é uma metáfora que nos coloca fora do mar do nosso próprio Inconsciente, mas oferece um equipamento de mergulho. Exprime, talvez com maior precisão do que o próprio nome científico, o conceito de "Inconsciente Coletivo", porque a melhor forma de acessar o Inconsciente, segundo a ciência do livro cabeceira de Fauzi - Psicologia e Alquimia, de Jung é através de figuras de linguagem, símbolos ou imagens. Não por acaso, ferramentas da arte.

Há um desafio e um caminho das pedras a ser rastreado no texto de Fauzi, ambos ligados a um nível de percepção que até hoje, milênios depois que algum homo sapiens comeu o primeiro cogumelo alucinógeno, ainda buscamos palavras para expressar. Nessa busca, um conceito relevante para esta investigação está na base das reflexões de Fauzi sobre o episódio ocorrido durante a montagem da peça Um Ponto de Luz, o segundo texto de Fauzi, dirigido por ele mesmo em 1976, e que compõe o corpo do capítulo 20 do livro, "o teatro da alquimia e a alquimia do teatro". Seria o conceito da "Sincronicidade", ou das chamadas "coincidências significativas", definido por Jung, basicamente, como a ocorrência de fatos com relação simbólica, porém não causal, com efeitos concretos na realidade, no mínimo através de sua influência na psique do observador. No correr do estudo se verifica que esse conceito está nos fundamentos do raciocínio de Fauzi em sua analogia dos eventos narrados com a chamada 
"alquimia do teatro" e vice-versa. E na busca da expressão dessa qualidade de fenômeno com sua sugestão de uma dinâmica oculta da realidade operando fora do condicionamento mental da causalidade e da linearidade - encontra-se a metáfora, a linguagem que "sugere o ato que se esconde por trás do aspecto visível. A metáfora é a máscara de Deus, através da qual a eternidade pode ser vivenciada" (CAMPBELL, 1991, p. 68). O mitólogo Joseph Campbel1 ${ }^{16}$ se refere à metáfora do mito como "um canal de comunicação com o mistério que você é" (1991, p. 68). Mas a metáfora leva consigo a influência dessa amizade com o mito. O Inconsciente descrito por Jung inclui o acervo do imaginário humano guardado no cérebro arcaico, a memória ancestral, fonte da poesia de todas as lendas, anedotas, literatura, dramaturgia. Todo tipo de narrativa nasceria nos campos simbólicos do Inconsciente Coletivo. A maior parte reflete a sociedade, existe para diversão e propaganda. Outra parte reflete a eternidade, são os mitos, que existem para "instrução espiritual" e revelam a trilha para o si mesmo. "A mitologia é a penúltima verdade, porque a última não pode ser transposta em palavras. Está além das palavras, além das imagens (...) A mitologia lança a mente para além dessa borda, para aquilo que pode ser conhecido mas não contado" (CAMPBELL, 1998, pg. 180).

Mircea Eliade ${ }^{17}$ em seu Mito e Realidade escreve que o mito, nas sociedades arcaicas, presentificava verdades sagradas que funcionavam como modelos sociais; fundamentados no segredo da origem das coisas, determinariam o Inconsciente Coletivo. De forma análoga, porém caótica, no mundo atual, mesmo soterrado pela sociedade da informação, o mito subsistiria oculto, difuso na cultura popular ou na percepção de cada um. Às vezes adulterado, mas ainda trabalhando incansável, camaleônico, comunicando o incomunicável e garantindo a linguagem viva no subtexto da realidade.

O mito entra nesta investigação quando Fauzi nomeia seu depoimento com uma expressão sinônima de Inconsciente Coletivo. A escolha sugere o libreto de suas entrelinhas e

\footnotetext{
${ }^{16}$ Joseph Campbell (1904 / 1987) - Mitologista, escritor, conferencista e professor universitário norteamericano, famoso por seus estudos de mitologia e religião comparada e autor da obra O Herói de Mil Faces, publicado originalmente em 1949. Com uma bolsa para estudar na Europa, estudou Francês arcaico e Sanscrito na Universidade de Paris e de Munique. Interessado na filosofia e mitologia hindu, conheceu e se tornou amigo de Krishnamurti. Quando voltou aos Estados Unidos publicou sua obra magna, "A Máscara de Deus" que explora os mitos e as culturas do mundo todo através dos milênios. Sua última obra publicada foi "Todos os nomes da Deusa".

${ }^{17}$ Mircea Eliade (1907 / 1986) Professor, historiador, mitólogo, filósofo e escritor ficcionista romeno. Formado em Filosofia pela Universidade de Bucareste, lecionou religião comparada na Sorbonne, recebeu título de Doctor Honoris Causa de numerosas universidades do mundo, foi premiado em 1977 pela Academia Francesa, e recebeu a Legião de Honra da França.
} 
inscreve o conteúdo do texto naquela categoria do que "pode ser conhecido mas não contado". Como sons harmônicos determinantes sobrepostos ao tom casual do texto, há uma dimensão de mistério impenetrável, que chama e acolhe o mythos no contexto do estudo. Tecnicamente, o mito seria uma linguagem indicada para o trato com o Mare Nostrum, no sentido do Inconsciente Coletivo. Funcionaria como uma chave inversa, um filtro pelo qual se pode ampliar ou revelar a eternidade de qualquer história. Especialmente a história e o depoimento de um ator-diretor-autor sobre sua experiência como criador de Teatro, já que esta arte, no contexto da cultura ocidental, é uma linguagem que evoluiu como prática profana a partir dos cultos ao deus grego Dioniso, um mito sobre um deus do êxtase e do entusiasmo, do vinho e das orgias, cultuado por sátiros e bacantes desde o século XIII a.C.

\section{A DIMENSÃO ALQUÍMICA DE DIONISO}

Significativamente, Dioniso é um mito essencialmente ligado ao enigma proposto por Fauzi no título do Capítulo 20, “o teatro da alquimia e a alquimia do Teatro". Segundo o mitólogo Junito Brandão ${ }^{18}$, é "o deus da metamórphosis, o deus da transformação (...) O elemento básico da religião dionisíaca é a transformação. O homem arrebatado pelo deus, transportado para seu reino por meio do êxtase, é diferente do que era no mundo quotidiano". (LESKY, apud BRANDÃO, 1987, vol.II, p.130) Por definição, a Alquimia é a grande arte da transformação: do chumbo em ouro, da prima matéria em pedra filosofal; de um ego incompleto em uma existência plena; ou de um ator numa personagem.

Se Dioniso é o deus da transformação, a ideia do "teatro da alquimia e a alquimia do teatro" ganha uma dimensão interessante, o Teatro traria sua própria tradição alquímica, desde sempre, na figura de Dioniso. Seria uma vertente própria de Alquimia, uma outra Grande Arte da Transformação, mais sugestiva do que clara, a ideia inspira a dúvida: transformação do que em quê? Do nada em teatro, da ideia em cena, do palco em infinito, são muitas as possibilidades. Do ator em personagem, ou do próprio Fauzi num novo Fauzi, como sugere a descrição de suas primeiras experiências lisérgicas nos termos de uma "revolução total de

\footnotetext{
18 Junito Brandão_ - 1924 / 1995 - Professor e grande classicista brasileiro, especialista em mitologia grega e latina, Traduziu direto do Grego para o português obras de Sófocles, Eurípedes e Aristófanes. Autor com dezenas de títulos, incluindo dicionários e obras didáticas, publicou livros sobre Mitologia, Teatro, Poesia Pastoril, o mito de Helena, $\mathrm{O}$ eterno Feminino, e outros.
} 
minha consciência vivida em apenas quinze dias, com apenas duas sessões, foi definitiva e marcou toda a minha vida" (ARAP, 1998, p.42).

Tudo no depoimento de Fauzi se coloca na perspectiva do Teatro, fala de como ele transformou suas experiências em teatro, como transformou vivência em cena. Essa "revolução total" que ele descreve fala da consciência de uma pessoa que estava em cartaz naquele momento, ensaiando e estreando outros projetos, totalmente envolvido no cotidiano teatral, inclusive ganhando o Prêmio Círculo Independente de Críticos Teatrais - ator revelação - pelo papel na montagem de A Mandrágora, de Maquiavel, pelo Teatro Oficina (1962), a peça que o levou para o Rio de Janeiro, quando conheceu o Dr. Murilo Pereira Gomes. Se é possível supor que existe algo como um arquétipo de Dioníso ativo no Inconsciente de alguns artistas, assumimos ser este o caso de Fauzi. Donde sua revolução interna se revelaria uma "transformação" causada pelo "êxtase dionisíaco". Não induzido pelo vinho, mas pelo LSD25. É fato a sincronicidade de sua transformação profissional com o processo terapêutico, que começa em 1963, durante a temporada de Mandrágora, no Rio, e termina em 1965, quando, aos 27 anos, sendo um entre os melhores, premiado, admirado, de repente Fauzi rompe contraditoriamente com a carreira de ator. Ao mesmo tempo, praticamente, estreia como diretor, já operando num alto nível. Morte-renascimento instantânea: coisa de alquimista.

\section{O INCIDENTE INCITANTE}

1963, Fauzi tem 25 anos e está em cartaz com a peça Mandrágora pelo grupo Arena no Rio de Janeiro, quando o interesse por psicanálise o leva a se engajar numa psicoterapia inovadora com base em sessões de análise com aplicação de LSD puro na veia de duas em duas semanas. Na época, a substância era um medicamento, o Delysid LSD25, produzido e distribuído pela multinacional Sandoz. Era uma novidade, mas um tratamento legal, considerado normal. O depoimento de Fauzi abre com o relato dessa experiência e a partir daí o narrador reflete sobre a vida e o teatro, e dá o testemunho de sua passagem no mundo. $\mathrm{O}$ encontro com o LSD é o incidente incitante da narrativa. Tudo que vem em seguida tem a ver com isso, as reflexões e os pensamentos sobre o teatro também. Mas vão além, porque o depoimento revela o feito que foi segurar a onda dessa experiência psíquica, naquela 
circunstância, naquele nível de sensibilidade, e ancorar um know how, sintetizar um savoir faire, materializar uma tecnologia garimpada nas esferas inefáveis pelas lentes lisérgicas. Fauzi escreve sobre a experiência:

\begin{abstract}
A Psicanálise tradicional, de alguma forma, fica parecendo um tratamento homeopático, vagaroso, comparada ao tratamento de choque que o LSD parece possibilitar. (...) As regressões quase instantâneas, e as memórias editadas como num compacto de vídeo, (...) parecem sugerir que o homem dispõe, com certeza, de neurônios que por estupidez não utiliza e que o LSD é capaz de ativar. Como se consultássemos o arquivo de um misterioso computador dentro de nós, e em nossas células, e descobríssemos mecanismos infinitamente sensíveis que a natureza e Deus colocaram à nossa disposição, mas que em nossa ignorância preferimos desprezar. E a inteligência da edição de todas as respostas é evidente, era evidente, viesse de onde viesse (...) As regressões pareciam ter vida inteligente, ou pelo menos um editor muito talentoso e oportuno. Tudo se encadeava lindamente, oferecendo-se como material de estudo e autoconhecimento." (ARAP, 1998, p. 40)
\end{abstract}

A descrição sugere uma experiência potencialmente útil ao extremo para o autoconhecimento e a criatividade. Além de perigosamente irresistível, a combinação do autoconhecimento com o prazer. Combinação, hoje, altamente questionada por toda carga de associações controversas ligadas às drogas alteradoras da consciência. Hoje, o LSD se confunde com outras substâncias, é uma droga de época, ou algo engolido sem cerimônia por cabeças de vento, encarado como um barato qualquer. Mas a história da influência desta substância na cultura mundial talvez demonstre uma importância ainda subdimensionada. Fauzi seria um ponta de lança local de um fenômeno histórico mundial que ajudou a deflagrar a revolução cultural nos anos 1960 e 1970, a contracultura dos hippies e tropicalistas, a poesia marginal, a grandeza da subversão necessária renovada pelo vento de um alterador da consciência que ganhou o mundo. No Brasil, Fauzi era ainda ponta de lança porque chegou mais cedo na festa. Mas nessa mesma época, os efeitos do LSD na cultura já se manifestavam de formas radicais nos EUA, rompendo completamente com os acordos implícitos e explícitos 


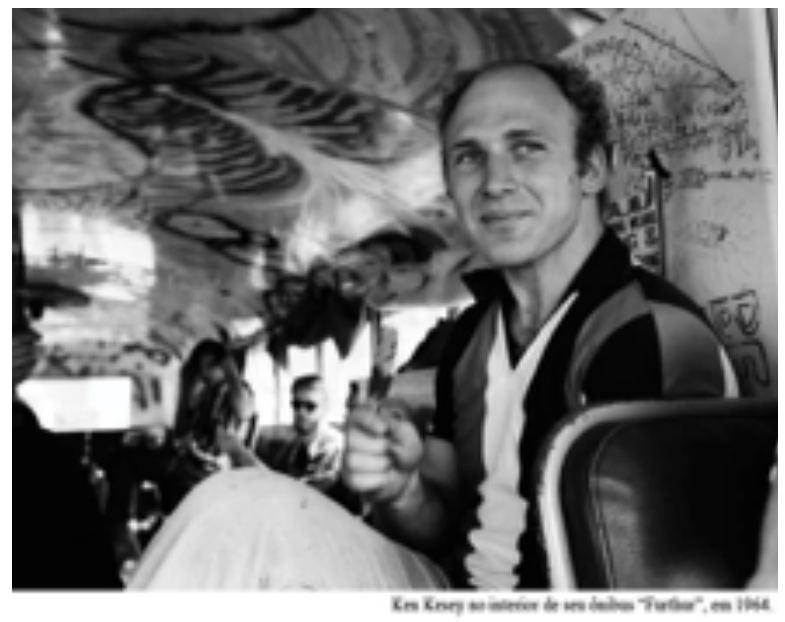

da normalidade. Como na experiência seminal do coletivo artístico Merry Pranksters ${ }^{19}$, registrada no livro "O Teste do Ácido do Refresco Elétrico", de Tom Wolfe ${ }^{20}$ (Rocco, 1993).O coletivo era liderado pelo escritor Ken Kesey²1, já então autor do best seller "Um Estranho no Ninho", que no ano de 1960 formou a primeira "comunidade alternativa" da história, promovendo saraus lisérgicos famosos, onde se delinearam conceitos-chave da contracultura histórica e da cultura pop desde então, além de fenômenos comportamentais que se tornaram referência mundial. Em 1964, no mesmo ano em que Fauzi viveu o auge de sua terapia lisérgica, Ken Kesey e seu bando partiam da Califórnia em direção à Nova Iorque num ônibus pintado com flores coloridas (o original, cuja imagem se tornou icônica), fazendo Happenings pelas praças do caminho, servindo Refresco Elétrico aos participantes. Inevitável analogia com a imagem de um

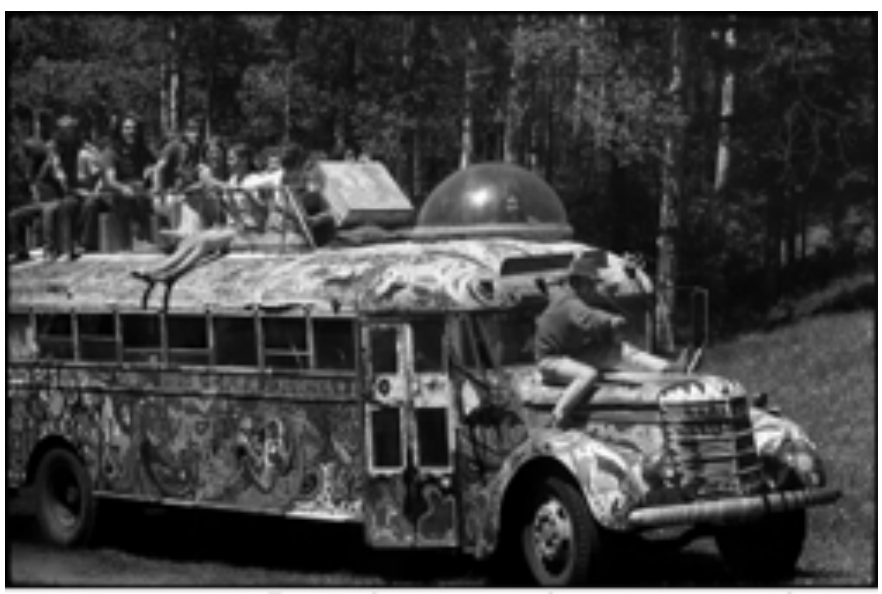

Ken Kesey em seu beibus, Furthur, Aspen Meadows, NM, 1969 por Lisa Law

\footnotetext{
${ }^{19}$ Merry Pranksters foi uma trupe artística de São Francisco, California, encabeçada pelo escritor Ken Kesey, que no início de 1960 realizou viagens performáticas a bordo de um ônibus escolar de nome Furthur (Mais Além, em tradução livre). Pintado com flores coloridas, o ônibus foi o original de uma imagem que se tornou famosa. Nas cidades pelos caminhos, faziam apresentações - festas com saraus performáticos que incluíam a distribuição de LSD. A substância ainda não era proibida e os saraus eram uma prática que vinham desenvolvendo desde 1960 num sítio em La Honda, próximo a São Francisco, onde alguns moravam em comunidade e muitos outros se juntavam para as festas. Os saraus de La Honda foram germinais no engendramento de conceitos psicológicos e comportamentais que vieram fecundar o movimento hippie, como a valorização de escolhas originais e uma visão crítica da sociedade normal, definida em La Honda como "o sistema". Na mais conhecida viagem do Further, partindo de São Francisco em direção a Nova Iorque, estavam a bordo 5 mulheres, 10 homens e uma curiosidade literária, o também escritor Neal Cassady, protagonista da Geração Beat por ser a pessoa por trás da personagem principal do romance On the Road, de Jack Kerouac. O destino da viagem seria apresentar o "know how" da trupe no trato do LSD numa feira mundial de tecnologia em Nova Iorque, mas antes disso, depois de muitas paradas lisérgicas, suas movimentações passaram a ser monitoradas pela polícia, e Ken Kesey acabou preso por porte de maconha.
}

${ }^{20}$ Tom Wolfe - 1930 / 2018 - Escritor e jornalista americano, autor de mais de uma duzia de livros, entre eles, "A Fogueira das Vaidades" best seller adaptado para o cinema por Brian de Palma com sucesso mundial de bilheteria.

${ }^{21}$ Ken Kesey (1935 / 2001) no final dos anos 50, como aluno da Universidade de Stanford, entra como ajudante e "sujeito experimental" numa pesquisa que incluía o uso de substâncias psicodélicas, experiência que inspira seu primeiro livro, de 1962 "Um Estranho no Ninho", um best seller adaptado para um filme ganhador de Oscar. Escreve várias outras obras de ficção e não ficção que detalham sua transformação de romancista em guru da geração hippie. 
cortejo dionisíaco e seu vinho sagrado.

A "viagem" de Kesey se desviou pelo caminho, mas fez história e somou forças com outros fatores culturais para precipitar uma revolução comportamental massiva, o movimento da contracultura dos anos 1960 e 1970, que envolveu milhões de pessoas e plantou ideias libertárias, pacifistas e humanistas. Entretanto, não podia dar certo por muito tempo, seja pela fragilidade da falta de método, com os riscos decorrentes, mas principalmente pela potência realmente libertária, foi corrompido, cooptado, abatido pelo sistema. Certamente o movimento foi fortalecido, senão impulsionado, pelo advento do LSD. A substância foi sintetizada em 1938 pelo suíço Albert Hoffman, distribuída como medicamento psiquiátrico pelo laboratório Sandoz a partir de 1947, exaltada como a possível salvação da humanidade por intelectuais importantes como Aldous Huxley e Timothy Leary ${ }^{22}$, e definitivamente proibida nos EUA em 1970 depois de uma campanha do presidente Richard Nixon, que chamou Leary - entusiasta e divulgador da substância como cientista renomado e professor de Harvard - de "o homem mais perigoso da América".

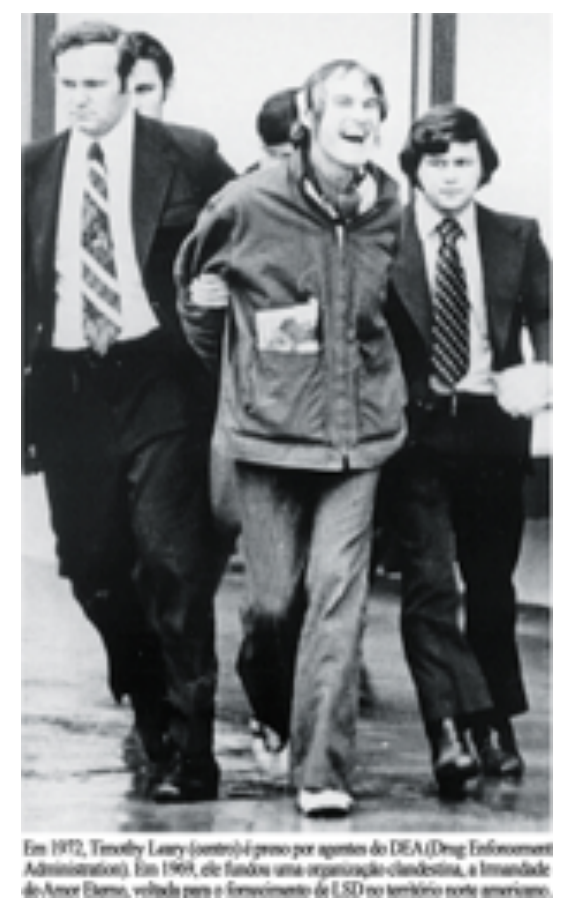

Chamam a atenção as palavras ditas por quem, na época, comandava uma guerra que dizimava milhões. O grande perigo seriam garotos e garotas usando roupas engraçadas, dançando, amando e dando risada, e não homens idiotizados matando com bombas e tanques de guerra.

Depois disso, a demonização do conteúdo libertário e a normalização compulsória do terror se aprofundou. Inclusive, o chamado sistema - termo que ganha, a partir de 1960, o sentido de uma espécie de rizoma psico-logístico operado pela classe dominante - parece ter se aproveitado da história, com o prestígio do LSD entre intelectuais e artistas deixando aberta uma porta que parece ter sido

\footnotetext{
22 Timothy Leary (1920 / 1996) professor da Universidade de Harvard, psicólogo, neurocientista, escritor, futurista, ícone dos anos 1960, pesquisador e escritor americano dedicado a pesquisa sobre o potencial terapêutico de substâncias psicodélicas, é expulso da Universidade de Harvard por suspeita de uso indevido do LSD, tornando-se um superstar da contracultura daquela década como militante pela difusão da substância como ferramenta para um salto de consciência da humanidade. Em 1970 o LSD é totalmente proibido nos EUA e, nos anos seguintes Leary protagoniza cenas de herói da contracultura, incluindo fuga espetacular da prisão e do FBI e parcerias com a guerrilha internacional. Mas se mantém livre e, de volta aos EUA nos anos 80 , se dedica ao pensamento ligado à informática e à inteligência artificial, e declara que os computadores são os psicodélicos do futuro. Em 1996, morre aos 75 anos, e tem as cinzas de seu corpo levadas pela nave espacial Pegasus e lançadas no espaço, juntamente com as de Gene Roddenberry, criador de Jornada nas Estrelas, e alguns outros cientistas.
} 
explorada pelos estrategistas do controle. Novas drogas foram lançadas para barrar a onda, não libertárias, mas escravizantes. E a sombra do legado do LSD é justamente a confusão entre substâncias que, usadas adequadamente, podem levar ao contato profundo com o inconsciente, e as substâncias puramente entorpecentes, que causam dependência química e degradação física e psicológica.

Pode-se dizer que essa onda toda, que anos depois quebrou no mundo como uma contracultura histórica de visão libertária e projeto pacifista e visionário, consciente e sustentável - tudo que hoje o mercado usa como slogan para tentar aliviar o vexame da falência absoluta dos escrúpulos - naquele momento, no Brasil, quebrou em cheio na cabeça de Fauzi praticamente sozinho. Ele olhava ao redor e tudo continuava igual: todo mundo de terninho, cantando bossa nova... Mas ele já não era o mesmo. Ou era muito mais ele mesmo, já que se sentia melhor e indisfarçavelmente entusiasmado com as grandes e fascinantes descobertas que se desenrolavam em seu cotidiano, a cada esquina, a cada encontro, sob as novas perspectivas abertas no processo terapêutico. Talvez um pouco entusiasmado demais.

Uma amiga, que Fauzi prefere não nomear questionou: "começou uma campanha, junto a mim, para que eu interrompesse o tratamento. Ela me dizia que eu é quem era muito especial, e que o LSD não tinha nada a ver, e muito menos o Dr. Murilo" (ARAP, 1998, p.55). Apesar do cuidado de Fauzi para não expor a amiga, acreditamos ser correto mencionar que ex parceiros em geral concordam que seria a atriz Johana Fomm sua principal interlocutora nos primeiros contatos com a substância, noção confirmada pelo ator e produtor Sérgio Mamberti, outro amigo de Fauzi, em depoimento para este estudo. Realmente, para quem acompanhava de perto a drástica mudança pela qual passava o ator, e testemunhava seu entusiasmo incontrolável para falar do assunto, devia parecer um terreno delicado. Sem entrar na questão da fragilidade de um paciente nesta situação, e a respectiva responsabilidade do terapeuta, o fato é que a ideia de uma tal experiência terapêutica em si parece terrivelmente atraente. Soa fascinante a ideia de uma aplicação racional, metódica, uma abordagem psicanalítica para uma viagem de ácido. Seria como sonhar e interpretar o sonho na mesma hora, e poder agir no sonho, integrando os complexos in loco. Um sonho ao alcance da mão.

No caso de Fauzi, isso acontecia duas vezes por mês. Uma coisa intensa. A terapia começou durante a temporada de Mandrágora, no Rio de Janeiro, com o Teatro de Arena, em 1963, e Fauzi não tem certeza, mas fala de uma possível última sessão em 1965. Se a parte 
clínica da terapia funcionou, se o terapeuta Dr. Murilo Pereira Gomes sabia o que estava fazendo do ponto de vista clínico psicológico, é possível supor que uma terapia quinzenal de qualidade, nessa intensidade, feita por quase dois anos, pode ir além de integrar complexos e expandir a consciência, pode ter resultados fantásticos. Porém, não seria tão simples.

Hoje existe mais conhecimento sobre experiências similares àquela vivida por Fauzi. O LSD em si está na raiz de todo um universo cultural com estética e mentalidade próprios, a

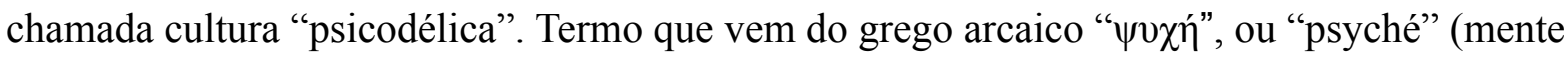
ou alma), e " $\delta \tilde{\eta} \lambda o \varsigma$ ", ou "dêlos" (visível, claro, manifesto), e segundo o pesquisador israelense Ido Hartogsohn, em artigo publicado no site psypressuk.com, foi cunhado pelo psiquiatra britânico Humphry Osmond ${ }^{23}$ em 1957, em correspondência com o escritor e conterrâneo Aldous Huxley ${ }^{24}$, buscando designar um grupo psicofarmacológico de substâncias com efeitos similares, incluindo a mescalina dos cactos mexicanos, a psilobina dos cogumelos mágicos, a dimetil triptamina da Ayahuasca amazônica e o próprio LSD, entre outros. O neologismo vinha substituir os termos 'psicotomiméticos' (drogas que imitam a psicose) e 'alucinógenos' o primeiro por enquadrar a experiência do efeito como patologia, e o segundo, por enquadrá-la como fenômeno imaginário sem relação com a realidade. O neologismo expressa reconhecimento de valor e respeito pela experiência da "manifestação da mente". Dificilmente Osmond e Huxley previam que uma década depois o termo se tornaria sinônimo de uma estética que avançaria pelo milênio seguinte mais ligada às indústrias da moda e entretenimento do que aos estudos da psique. Talvez por isso mesmo, vinte anos depois, em 1979, surgiu um novo neologismo para designar o mesmo grupo de substâncias, cunhado por um grupo de pesquisadores que inclui o classicista Carl Ruck e o micologista R. Gordon Wasson (autores estudados adiante no capítulo Teatro Nuvem) justamente para distinção do termo "psicodélicos", então identificado com a excessiva cultura das drogas dos anos 1960. O

\footnotetext{
${ }^{23}$ Humphry Fortescue Osmond (1917 / 2004) psiquiatra inglês que viveu no Canadá e EUA, conhecido por pesquisas sobre aplicações para substâncias psicodélicas. Em correspondência com o escritor Aldous Huxley, o romancista defendia a criação de outro nome para designar as substâncias psicodélicas, sugeria phanerothyme,

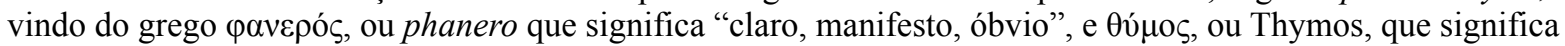
espírito ou espirituosidade. Mas Osmond inventou o termo "psicodélicos" e sua defesa para o neologismo mostra consciência de quem sabe a palavra certa. Sobre o termo, afirmou ser: "claro, melodioso e não contaminado por outras associações". Também pesquisou a fundo a psicologia dos ambientes sociais.

${ }^{24}$ Aldous Leonard Huxley (1894 / 1963) foi um escritor inglês que viveu parte da vida nos EUA nos Estados Unidos, escritor de literatura, roteirista e pensador, autor livros importantes como o romance Admirável Mundo Novo, de 1931, e o ensaio As Portas da Percepção, de 1954, sobre experiências com a substância Mescalina, livro cuja influência sobre a cultura hippie inspira do nome à icônica banda The Doors, apesar da hipótese de ser de um verso de William Blake: "Se as portas da percepção fossem limpas, tudo pareceria ao homem como é, Infinito."
} 
novo termo, "enteogênicos", também vem do Grego arcaico: ěv $\theta \varepsilon o \varsigma$ (éntheos), raiz da palavra entusiasmo, significando literalmente "deus dentro", e $\gamma \varepsilon v \varepsilon ́ \sigma \theta \alpha l$ (genésthai), que significa “tornar-se". A ideia era preservar um discurso imparcial sobre o uso tradicional ou religioso destas substâncias em contexto xamânico ou espiritualista. Vale notar que aí não se inclui o contexto psicoterapêutico, como foi o caso de Fauzi, indicando, entre outras coisas, o abandono dessa prática e desse tipo de pesquisa no início dos anos 1970, com a proibição total do uso do LSD nos EUA, depois de abusos de tipos variados - de experimentos de controle mental por parte da CIA a pesquisadores independentes e usuários descontrolados. Atualmente há um movimento de setores da classe médica para resgate e evolução dessa linha de trabalho, demonstrando eficácia no tratamento de disturbios da psique como depressão, trauma e dependência química (ver MAPS - sigla em inglês para Associação Multidisciplinar de Estudos Psicodélicos - nos EUA, e no Brasil, o trabalho do psiquiatra e neurocientista Eduardo Schenberg). O fato é que o uso desse tipo de substância para "estudos da alma" ou curas de todo tipo é uma prática ancestral no contexto do Xamanismo, algo universal se entendido como expressão religiosa dos povos arcaicos, das tribos da Sibéria às tribos das florestas tropicais ou de todo tipo ao redor do mundo. Um conjunto de práticas, medicinais, animistas, filosóficas, ou metafísicas, técnicas de contato com o sagrado, ou o êxtase, envolvendo o transe e utilizando uma linguagem que está na origem da poesia e das artes cênicas. E com ramificações nas tradições indígenas brasileiras, onde o "xamã" se chama "pajé", com influência para além do contexto tribal, incluindo o Catimbó Jurema de Pernambuco, entre outras, principalmente a chamada "Cultura Ayahuasqueira", de origem amazônica, baseada no uso ritualístico da bebida tradicional dos povos da floresta (Ayahuasca) e atualmente praticado por centenas de milhares de pessoas no mundo, integrando um movimento global de renovação do xamanismo no contexto urbano. Na perspectiva "enteogênica”, o uso dessa classe de substâncias seria adequado a prática xamânica, religiosa ou pré-religiosa porque toca em questões delicadas e imensas na própria estrutura da psique, instâncias definidoras da camada etérea determinante da realidade, por trás de cada escolha, de cada gesto. E normalmente tocaria essa instância com uma delicadeza potencialmente esmagadora, de algum jeito terrivelmente maravilhoso. Por isso seria algo a ser feito com todo um cuidado específico, num ambiente seguro para o aprendizado e prática da aplicação da ação da substância no desenvolvimento do auto-conhecimento e da expansão 
da consciência. Já a perspectiva "psicodélica" propõe a experiência em estilo livre, com propósito livre, no contato com a realidade cotidiana pelo prisma de uma consciência tocada em suas capacidades de percepção e ação no mundo. Algo talvez mais arriscado, mas eventualmente válido. São métodos fundamentalmente diferentes mas talvez complementares para o aprimoramento da experiência do mundo sensível e do mundo intangível dentro e fora de si mesmo.

Para alguém como Fauzi, artista sério, de sensibilidade aguda, intelectual, materialista dialético como toda sua geração, isolado, sem ter com quem compartilhar, a experiência parece ter sido um desafio psíquico difícil de dimensionar. Ele poderia realmente ter ficado louco. Na verdade, muitos acharam que tinha ficado. Ele foi julgado. E talvez tenha estado louco em algum momento, mas deu um jeito de transformar a experiência em poder criativo. E o jeito dado tem a ver com a origem terapêutica que distingue sua experiência com LSD25 da maioria que veio depois com a difusão do uso recreativo no final dos anos 1960. A experiência de Fauzi desafia as duas nomenclaturas, psicodélica e enteógena: ele teve sua prática sempre voltada para o auto-conhecimento e algum tipo de cura, mas não em caráter explicitamente xamânico ou religioso, e sempre vivenciada de forma mais ou menos livre e em contato com a realidade cotidiana, de sessões de análise no consultório à sessões de solidão criativa ou convívio humano. Para Fauzi, a experiência lisérgica sempre foi um estudo sério, uma ferramenta de autoconhecimento, apaixonante, mas essencialmente libertária. Uma epifania com raios divinos, inclusive, fulminantes, que ele encarou vivendo o inferno pessoal da incompreensão de seus pares diante de sua transformação. Na desconfiança e no desprezo do mundo diante de seu olhar maravilhado para a eternidade dançando nos detalhes da vida, ele duvidou de si mesmo. E nessa dúvida, morreu alguma coisa. Inesperadamente, ele deixou de ser ator. Mas não deixou de ser artista, ao contrário, quebrou o monopólio das narrativas oficiais numa instância mental em disputa, criou sua realidade poética em pleno massacre autoritário, deixou lembranças e um testemunho que revelam uma sabedoria teatral peculiar, e talvez uma tecnologia que instiga ser desenvolvida. A experiência pede que se extraia dela uma informação necessária. Especialmente num tempo em que alguém comprou os direitos de uso da frase paz e amor, em que Liberdade virou o nome da lei do mais forte sem noção; a 
efeméride dos 50 anos de Maio de $68^{25}$ foi pouco celebrada, Bob Dylan ganhou o Nobel de literatura, mas alguém ainda leva a sério o "poder das flores", ou "paz e amor"? Ou o próprio “amor", livre ou não. Hoje, os valores abstratos são confundidos com rótulos vazios. Na disputa de narrativas do mundo, a contracultura histórica dos anos 1960 e 1970 parece apagada de propósito por opositores. Os novos funcionários da mídia já não sabem mais como usar essa imagem, já não conseguem encaixar, no curso da embromação geral, o legado de um levante libertário, pacifista e humanista, que não combina com as narrativas oficiais impostas na zumbilândia. Hoje, 2018, a liberdade se disputa com um dragão de mil cabeças num tiroteio de narrativas que abusam da origem dionisíaca para quebrar a alma do cidadão reduzido a cliente escravo com desejos e emoções inoculados. Os símbolos se confundem com qualquer imagem, mais uma história inventada, como tantas. E os padrões funcionais são marcados em brasa na psique geral pelos capitães-do-mato transformados em cultura de massa.

Numa situação como essa, grita a experiência de Fauzi rompendo a narrativa oficial e plantando sementes libertárias que advogam a liberdade da alma. Filho irredutível da contracultura histórica, encantou as massas, mas não negociou com a cultura de massas adulterada pela banalidade. $\mathrm{Na}$ vida pessoal como na arte, exerceu a liberdade e seu depoimento se aplica como uma espécie de mapa criptografado para uma mina de águas profundas, necessárias em tempos em que o massacre autoritário se renova. Fazendo sucesso com peças profundas e herméticas, transformando o próprio hermetismo em cultura pop, entre outras façanhas, Fauzi aconteceu no tempo como um herói num filme de transe, vagando em paisagens oníricas, decifrando percepções raras, colhendo estrelas pra fazer poesia. Num estudo mais fino, bem menos distraído do que essa imagem pode sugerir.

\footnotetext{
${ }^{25}$ Maio de 68 - No dia 2 de maio de 1968, estudantes franceses da Universidade de Nanterre fizeram um protesto contra a divisão dos dormitórios entre homens e mulheres, e o acontecimento foi o estopim de uma revolta de proporções nacionais, e simbolicamente transnacionais, de uma geração que pedia o fim de posturas conservadoras. O movimento de Maio de 1968, na França, tornou-se ícone de uma época onde a renovação dos valores veio acompanhada pela proeminente força de uma cultura jovem. A liberação sexual, a Guerra no Vietnã, os movimentos pela ampliação dos direitos civis compunham toda a pólvora de um barril construído pela fala dos jovens estudantes da época. O movimento cresceu tanto que evoluiu para uma greve geral de trabalhadores que balançou o governo do então presidente da França, Charles De Gaulle. Convocadas novas eleições, estudantes e trabalhadores foram desmobilizados e o movimento acabou.
} 


\section{AVE PARADOXO}

1965, primeiro ano do Golpe Militar, clima tenso nas ruas do Rio de Janeiro, mas a vida continua. E Fauzi está em cartaz na cidade interpretando o revoltado personagem Tiêteriev na montagem de Pequenos Burgueses com o Teatro Oficina. Numa entrevista para a revista Cláudia, a diva Fernanda Montenegro declara que "entre suas três maiores emoções como espectadora" estava Fauzi Arap, em Pequenos burgueses, ao lado de "Gérard Philipe fazendo O idiota e Galina Ulanova dançando Romeu e]ulieta" (ARAP, 1998, p. 66). Sobre o mesmo papel, o então crítico de teatro Paulo Francis publica na Revista da Civilização Brasileira que Fauzi: "conseguia criar o que Coleridge chamava de "suspensão da descrença". (ARAP, 1998, p. 66) Além disso, o autor relata que o papel, "lembrado até hoje por quem viu", lhe rendia "bilhetes e declarações de amor de pessoas desconhecidas" (ARAP, 1998, p. 66). Tudo indica que o ator vivia um momento de excelência artística. Porém, segundo o depoimento, ao mesmo tempo ele vivia uma intensa perturbação psíquica, com sensação interna de inconformidade e inadequação na vida pessoal e profissional.

(...) eu vivia naquele momento uma verdadeira esquizofrenia cênica. O sucesso era como se não fosse meu. Eu sobrevivia, continuando a representar, e, enquanto durava o espetáculo, eu mergulhava plenamente no papel, de forma quase suicida (...) [vivia] uma angústia permanente, minha ou do personagem, e não me conformava por ter me perdido tanto de mim. (...) Eu tentava cegamente me socorrer das palavras, já que ia descobrindo que toda experiência lisérgica parecia não caber na minha vida, tal como era antes. (ARAP, 1998, p.66)

O estado de espírito é associado pelo autor ao processo terapêutico com Dr. Murilo, que, àquela altura, já contava dois anos e chegava perto de seu final. Mas seria precipitado supor, pela situação, que a terapia lhe fazia mal. Observamos como o ator se sentia um ano antes:

Meu cotidiano havia se transformado em algo absolutamente mágico (...) Também meu trabalho de ator alcançou uma qualidade e um autodomínio incríveis. Além do que me revelei, até para mim mesmo, um ótimo orador! Minha timidez desaparecera, e me surpreendi em debates e palestras exibindo uma fluência e uma facilidade de expressão muito especiais, para quem nunca ousara falar em público sem um texto decorado. Meu novo poder de concentração não conhecia limites e eu tinha uma enorme firmeza e certeza do que queria, e sempre confiava no desenrolar dos fatos e na sustentação da inspiração, que nunca me faltava. (ARAP, 1998, p. 54) 
Nesses termos, a terapia parece ter sido um fator determinante para que ele alcançasse o alto nível de qualidade artística impresso em suas atuações no período. Então, porque seria, quase ao mesmo tempo, fonte de tamanha angústia? O motivo é altamente significativo e encontra raízes nas dinâmicas mais ancestrais da arte teatral, que estudamos no capítulo Teatro Nuvem. Antes disso, a explicação figura no depoimento:

\begin{abstract}
[eu] não contava com esse tipo de surpresa, capaz de desestruturar de vez minhas recém-conquistadas conviç̧ões materialistas. (...) ao mesmo tempo um enorme alívio, uma euforia serena, como se eu adivinhasse que aquilo significaria uma libertação definitiva. (...) [e talvez] uma espécie de culpa por estar merecendo uma libertação individual, particular, só minha (...) não suportava ter tido acesso a um segredo tão descomunal e incomunicável. (...) Não parecia fácil integrar tamanho salto de consciência com os princípios materialistas muito enraizados (...) [que] pareciam confundir-se com a própria ideia de bom senso. Não seria egoísta uma salvação tão particular? (...) Murilo tentou traduzir meu sentimento (...) afirmando que quanto mais um homem se volta para dentro, mais consegue sair de si para encontrar e ajudar o próximo. (...) de certa forma, nesse dia, Murilo cortou o cordão umbilical que me prendia à minha adolescência política. (ARAP, 1998, p.52)
\end{abstract}

Fauzi não era o único artista, naqueles primeiros anos da década de 1960, no Brasil, que experimentava o LSD25 em terapia (ou não), mas não consta que tenha encontrado outros "experimentados" nesses dois ou três primeiros anos. A sensação que ele reporta é de isolamento total. E talvez esta sensação tenha se agravado pelos termos que encontrou, num primeiro momento, para manifestar sua ânsia de compartilhar o incompartilhável: "me transformei num tagarela que só falava sobre seu assunto favorito, o ácido lisérgico, e não percebia o enorme escândalo que ia provocando, escândalo ainda maior quando falava em Deus ou Jesus" (ARAP, 1998, p. 45).

Certamente, no contexto da vanguarda do teatro paulista e carioca do começo dos anos 1960 - ambiente influenciado pelo pensamento materialista, a psicanálise e outras tendências intelectuais - a escolha dos termos "deus" e "Jesus" para tentar comunicar uma experiência lisérgica talvez só se explique como um caso emblemático da ação dos símbolos veiculados em cena no inconsciente de um ator.

Em 1963, Fauzi ensaiou por um mês com Antunes Filho para sua montagem de Vereda da Salvação, de Jorge Andrade, que considerava uma obra prima, e na qual ele faria o papel de Joaquim, um personagem que enlouquece se imaginando um novo Cristo. Mesmo não estreando, Fauzi viveu intensamente os ensaios, a ponto de guardar as falas na memória por décadas:

(...) minha própria vida, guardadas as diferentes circunstâncias, aos poucos começou a se confundir com a daquele personagem. Eu insistia em usar a figura de Cristo em 
minhas andanças e conversas noturnas em bares, nas calçadas, nos lugares mais inoportunos. E muitos acabaram achando que eu enlouquecera e que imaginava ser um novo Cristo. (ARAP, 1998, p. 45)

Jung fala sobre um estado psíquico da inflação, quando há uma identificação do ego com um arquétipo, trazendo sentimento de grandeza. As maravilhas que Fauzi tentava generosamente compartilhar, escandalizando a classe teatral, por um lado, refletiam essa dinâmica psíquica. No caso, de identificação com o arquétipo do Sol, “"avatoגń tou

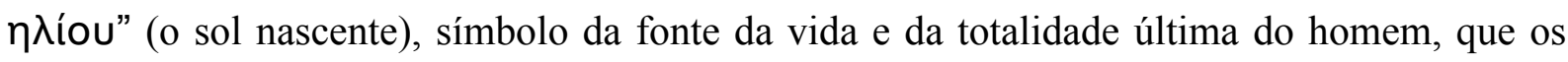
cristãos dos primeiros séculos tinham uma certa dificuldade em distinguir do Cristo." (JUNG, 1972, p. 94). É curioso o quanto Fauzi surpreende os interlocutores dando passagem a este arquétipo pela figura de Cristo - fora do contexto religioso, um símbolo carregado pelo tradicionalismo, desgastado pelo tempo. Segundo Jung, alguém como Fauzi normalmente manifestaria este estado psíquico através de outros símbolos, não este, culturalmente comprometido:

(...) um paralelo entre Christus-lápis (Cristo-Pedra Filosofal) dá ensejo a uma comparação entre as representações da meta do "opus alchymicum" (...) importante para a prática da psicoterapia, pois, não raro os pacientes cultos e inteligentes, cujo retorno à igreja é impossível, entram em contato com material arquetípico (JUNG, 1972, p. 43).

O sociólogo e criminologista norte-americano Lewis Yablonsky²6, no livro "The Hippie Trip", classifica como um "high priest" a figura do usuário entusiasmado que buscava convencer todos a compartilhar da experiência lisérgica (a palavra "high" significa ao mesmo tempo "grande" ou "principal" e "chapado", ou sob o efeito da substância, qualificando a palavra "priest", que significa "sacerdote"). Sem dúvida, Fauzi se encaixaria nesta classificação: "Talvez eu sentisse também uma espécie de dever de iniciar outras pessoas, não sei bem por que. Deus, para mim, ficara associado a experiência do ácido e, como um profeta ou pregador, eu queria reparti-lo com o maior úmero de gente possível, sempre que pudesse. (ARAP, 1998, p.81)

Dois casos extremos de "high priest" foram os citados Ken Kesey e Timothy Leary. E na comparação se torna evidente o processo alquímico de Fauzi - que pôde transformar a experiência lisérgica em Teatro, em vez de fazer desta o grande mote de sua vida, como conta a fama destes dois autores. Talvez, inclusive, Fauzi tenha escapado deste caminho também

${ }^{26}$ Lewis Yablonsky (1924 / 2014)_Professor Emérito de Sociologia e Criminologia na Universidade do Estado da California, em Northridge, sociólogo, criminologista e psicoterapeuta. É autor de mais de 17 livros, 15 dos quais se tornaram bestsellers, traduzidos em 12 linguas. 
graças a esta coincidência, de estar, na mesma época, ensaiando o louco Joaquim, de Veredas da Salvação. Joaquim se acha um novo cristo, e Fauzi decorou suas falas. Quando ele entrou em identificação com o arquétipo, a manifestação encontrou, firmadas naquele momento em seu inconsciente, palavras fortemente análogas à sua natureza solar, mas pela chave da loucura. E ainda comprometida com toda uma iconografia totalmente desgastada, "um novo cristo", especialmente naqueles dias, no meio intelectual que cercava os grupos Arena e Oficina.

Talvez, se ele tivesse ensaiado uma peça que não falasse de Cristo, mas de Buda, ou Krishna, ou mesmo de Helena Blavatsky ${ }^{27}$, que depois foi uma forte influência, certamente estaria bem mais "na moda" e talvez o efeito fosse o oposto. Aquele entusiasmo que parecia bizarro na boca de um jovem intelectual de esquerda falando em Jesus Cristo, se ele falasse em Krishna, por exemplo, seria diferente. Não estaria invocando um cristianismo caquético e comprometido aos ouvidos de seus interlocutores, mas uma iconografia exótica e atraente que tinha tudo para virar moda. Como realmente virou, pouco depois, na influência da percepção lisérgica no mundo. Fauzi era muito carismático, sabia o que estava falando, tinha o que dizer, e devia ser de muito valor para quem se abria para ouvir. O depoimento mostra o valor de sua visão na época infinitamente acima do calcanhar de Aquiles social que pode ter sido parecer uma espécie de pregador lisérgico falando em Jesus Cristo, ou qualquer outra coisa que ele possa ter dito em sua "euforia serena" pelas boemias cariocas dos tempos da Bossa Nova. Com uma resposta diferente de seus interlocutores, talvez aquele cotidiano "absolutamente mágico" prevalecesse, tanto quanto ele alcançou, como ator, "uma qualidade e um autodomínio incríveis". Afinal, tinha acabado de se descobrir “ótimo orador!”, bom de "debates e palestras" com "fluência" e expressividade, "concentração" sem limites, firmeza, certeza e confiança numa “inspiração” infalível. O que poderia segurá-lo?

Eu não tinha a menor noção de que assustava e torturava as pessoas, relatando exaustivamente as experiências mais sutis, que eu deveria deixar guardadas com delicadeza em meu coração. Eu confundia a reação emocional ao que eu dizia com eficiência ou eficácia na comunicação, como se eu fosse um ator que buscasse de qualquer forma a empatia da plateia. E acabava me embriagando com meu próprio discurso, talvez porque não quisesse de forma alguma voltar a meu antigo mundo, no qual eu não passava de um ator tímido, sem coragem para colocar as suas opiniões. E eu continuava a ignorar o abismo que começava a me separar de meus

\footnotetext{
${ }^{27}$ Helena Blavatsky (1831 / 1891) Helena Petrovna Blavatsky foi uma escritora russa, responsável pela sistematização da moderna Teosofia e cofundadora da Sociedade Teosófica, voltada para a promoção dos ensinamentos antigos de teosofia, a sabedoria relacionada ao divino, que era a base de outros movimentos do passado, como o neoplatonismo, o gnosticismo, e as Escolas de Mistérios do mundo clássico.
} 
companheiros pelo apego a esse novo vício, falar sem parar sobre coisas impossíveis. (ARAP, 1998, p.55)

Podemos imaginar o que aconteceria se Fauzi não escolhesse esses termos culturalmente comprometidos ou simplesmente estranhos para se expressar. Talvez não desse brecha para o descrédito, talvez não fosse estigmatizado ou subjugado e, se ficasse confortável com a resposta das pessoas, seus raciocínios visionários teriam florescido de outra forma. Ele já era famoso, jovem e genial, quem sabe atrairia muitos colaboradores, quem sabe, faria sucesso como guru psicodélico e a história seria totalmente diferente, mas Dioniso tinha outros planos:

O que eu tentava desastradamente comunicar era (...) Cristo enquanto arquétipo, encontrável no próprio coração de cada um. Esses mesmos livros alertam para a inutilidade de tentar repartir discursivamente com o próximo esse tipo de verdade, e para o fato de que o incauto, que incorre nesse tipo de erro, acaba, quase sempre, vítima de sua ignorância e merecendo apenas descrédito. E eu, esquecido da totalidade do processo, continuava a tentar criar apenas com palavras uma fórmula mágica capaz de transferir minhas descobertas a meus amigos, absurdamente no ambiente de uma noitada de bar. (ARAP, 1998, p.48)

Fato: naquela temporada, de 1963 para 1964, Fauzi não hesitou em sair usando entusiasmadamente a figura de Jesus Cristo em suas andanças e conversas noturnas, deixando registrada a suspeita de estar sob a influência do papel que nunca estreou na peça dirigida por Antunes Filho. O comportamento agravava todo entusiasmo ostensivo com o qual ele abordava o assunto do LSD, que acabou se tornando uma espécie de escândalo, já que era um artista conhecido e seu comportamento exótico chamava muita atenção. Um escândalo que caiu sobre o ator como uma bomba: "Quando viajamos para o Rio em 1965, eu já não tocava mais no assunto do LSD com ninguém. Mas, secretamente, o desafio de compreender tudo aquilo que eu vinha vivendo naqueles dois anos, até pela dor que eu sentia, era inadiável.” (ARAP, 1998, p.95)

\section{O INCOMUNICÁVEL OU A ANGÚSTIA DA REPRESENTAÇÃO}

Ao narrar esse impacto direto da terapia lisérgica sobre sua vida cotidiana, Fauzi descreve a maravilha e o desespero de perceber uma dimensão imensa da realidade pulsando tremenda no próprio sangue, sem poder compartilhar a experiência com quase ninguém, de jeito nenhum. Com isso, lança o foco para a dimensão do incomunicável: é numa relação intensa e desafiadora com o que não se traduz que Fauzi encontra os caminhos para 
compartilhar efetivamente sua percepção renascida em picos de inspiração extrema. Nessa dinâmica se materializa a obra. Cronologicamente, ele está no auge desse movimento psíquico, que inclui um tipo de angústia da representação, quando passa pelo processo criativo do Tiêteriev. Quem sabe, um olhar sobre esse processo criativo guarde o acesso a técnicas e iluminações que o ator alcançou para criar sua interpretação poderosa, sem que ninguém precise para isso tomar LSD25 com terapeuta nem abrir falência social. Ele deixa pistas sutis:

\begin{abstract}
(...) me reeduquei para tentar caber no convívio dos outros, sem escândalo. Fui participando como pude das peças - Pequenos burgueses, e depois Andorra, lutando para me superar e fazer bem meus papéis. Tive enorme dificuldade em ambas (...) consegui algum progresso. Eu não tinha por parte do grupo, nem do diretor José Celso, nenhum retorno positivo do meu trabalho, e essa falta de confirmação interna me deixava desorientado. Aquilo me obrigou a uma busca contínua de aperfeiçoamento. Eu não desistia e lutava para sobreviver com dignidade, e dia a dia fui me aprimorando e aprendendo. Esse exercício continuado foi fazendo com que, sem que eu soubesse, começasse a nascer em mim o diretor. (ARAP, 1998, p. )
\end{abstract}

A princípio, qualquer tipo de angústia ou perturbação é indesejável. Por outro lado, é quase certo que a situação psíquica do ator no período contribui substancialmente com sua construção genial da personagem. Nas poucas palavras sobre os ensaios, fala sobre aprimoramento, superação, perseverança mesmo sem estímulo, e uma frase chama atenção: "lutar para sobreviver com dignidade." De alguma forma, a afirmação sugere o quanto, naquele momento, Fauzi se sentia indigno, humilhado por estar agora solitário, desorientado e mal compreendido, depois de voar tão alto e conhecer uma liberdade definitiva. Além do estigma de doidão, como ator formado no teatro universitário da época, um ambiente intelectual de esquerda, com certeza uma parte dele vê naquela situação uma falência social absoluta. Um tragédia para seu ego e para sua reputação. Tragédia que ele reconhecia e por isso lutava "para sobreviver com dignidade", humildemente, se equilibrando na dignidade possível de sua situação, e assim descobrindo, inclusive, o caminho para a alma do Tiêteriev. Na prática, ele estava ocupado em criar uma interpretação cuja fama atravessa décadas, o que leva a uma conclusão desconcertante: se o instrumento de trabalho do ator é o próprio corpo físico, mental e emocional, pode-se concluir que este instrumento, no caso, apesar da angústia, da confusão e da dor psíquica, estava num estado próximo à perfeição e aplicação plena de seu potencial e qualidade.

Há uma questão de valores em jogo. O que vale mais: sentir-se confortável dentro da própria pele ou realizar-se plenamente no exercício de sua arte? Não seria esse, em última 
instância, o propósito de todo artista? E seria aquele, em última instância, o propósito de toda vida?

Mas nem tudo é angústia na vida do artista. No meio daquela crise, uma cena boa com a atriz Maria Alice Vergueiro ${ }^{28}$, sobre quem ele escreve: “As pessoas, como Maria Alice, que acreditavam em minha palavra, conseguiam fazer emergir o melhor de mim. Diante delas minha intuição se manifestava plena" (ARAP, 1998, p.79). Segundo semestre de 1965, Maria Alice liga pra Fauzi e diz, burocrática, que tomou o ácido, mas não está sentindo nada:

(...) havia tomado junto com seu médico, e que estavam os dois numa Choperia em Pinheiros, bebendo. (...) eu não poderia imaginar como um profissional minimamente responsável pudesse praticar um ato de tamanha imprudência (...) fui imediatamente a seu encontro, e lá descubro que, enquanto ela não sente nada, o médico sim está louquíssimo.” (ARAP, 1998, p.78)

Tratava-se de um médico que Fauzi havia consultado depois de romper com Murilo, e não tinha confiado nele. Alice explica que ele é primo de uma amiga e está em crise, enfrentando uma separação, e ela está "careta". Então Fauzi cuida dos dois, encaminha o médico com a prima e consegue a proeza de conduzir Alice a uma boa experiência. Ele reflete sobre a:

(...) importância do exercício de nossa vontade, que temos a liberdade de exercer ou não (...) atraímos sincronicamente o que nos é similar, e não sei até que ponto o episódio envolvendo Maria Alice não espelhava minha própria confusão e quem sabe um desejo inconsciente de minha parte de pretender, de alguma forma, usurpar o papel do médico no processo. (ARAP, 1978, p.)

Por outro lado, isto também pode ser visto como uma primeira manifestação de dom terapêutico que mais tarde se desenvolve.

Semanas depois, Maria Alice aparece com dois comprimidos roubados do médico, e Fauzi a convence a dar para algum amigo, para que mais pessoas tenham a experiência. “Talvez, no fundo, eu desejasse que um número maior de pessoas experimentassem o ácido, para me sentir acompanhado." (ARAP, 1998, p.80).

\footnotetext{
ALÉM DO TEMPO

${ }^{28}$ Maria Alice Vergueiro, 1935, atriz, pedagoga e professora universitária paulistana, com extensa carreira no teatro, cinema e televisão. Estreou em teatro em 1962, na peça A Mandrágora, dirigida por Augusto Boal. Atuou também no Teatro Oficina, inclusive na histórica montagem de $O$ Rei da Vela, de Oswald de Andrade, direção de José Celso Martinez Corrêa. Colaborou com o grupo de teatro norte americano Living Theater em sua passagem pelo Brasil. Fundou, juntamente com Cacá Rosset e Luiz Roberto Galizia, o Teatro do Ornitorrinco, onde atuou como atriz e também como assistente de direção. Em 2017 estreia a peça Why the Horse, espetáculo que encena o próprio velório, ainda em cartaz ao tempo da redação desta nota.
} 
A concentração de eventos significativos para o artista no ano de 1965 chama atenção para a questão da atemporalidade. A certo ponto, sete anos depois, sobre um episódio testemunhado na Casa das Palmeiras, ele conclui “Aquilo que poderia ser considerado apenas uma confusão era, para mim, um sinal de que todo símbolo resulta atemporal em sua expressão e por isso passível de ser justaposto a outro distante, no tempo e no espaço" (ARAP, 1998 , p.). E no contexto dessa "alquimia do teatro", filha do pensamento de Jung, autor do conceito de "coincidências significativas", talvez a grandeza da performance do ator em Pequenos Burgueses, como o significado poético da peça, especialmente do papel de Tiêteriev, guarde relação simbólica, efetiva porém não causal, com a dinâmica subjetiva vivida pelo ator na época. Mais que isso, guardaria uma relação simbólica com toda sua trajetória. Se, para Fauzi, "todo símbolo resulta atemporal em sua expressão e por isso passível de ser justaposto a outro distante, no tempo e no espaço", quando ele fazia o papel de um bêbado cético que confrontava os circunstantes com discursos filosóficos questionadores, vivia de alguma forma um paralelo com sua própria vida, num momento em que lidava com o choque de uma terapia com LSD25 que o lançara numa perspectiva da vida totalmente destoante daquela então aceita pela totalidade de seus parceiros: "A lucidez impotente do personagem se parecia com a minha, naquele momento, e talvez eu não estivesse representando exatamente um bêbado, mas um ex-lisergisado, perdido de si mesmo." (ARAP, 1998, p. 38).

Quando o ator pronuncia as palavras da personagem nos momentos finais da peça, em referência à iminência da revolução Russa: “a vida avança, velho! E quem não avança ao lado dela fica só", talvez se imprima em sua sua voz, naquele ano de 1965, não só a aflição de toda a sociedade diante do movimento de ruptura democrática que atingia o país e outras revoluções ainda por vir, uma metáfora clara na peça - mas igualmente sua própria problemática frente aos impasses psicológicos que atravessava, e que ele já sabia ser uma revolução inexorável. Fauzi reflete sobre a relação entre seu desempenho e o momento histórico com tantos mortos e torturados por se revoltarem contra a situação política:

Em nome da estética ou da própria política, eu participara de um teatro extremamente poderoso, no momento histórico em que tudo aquilo tivera origem, como ator-porta-voz e veículo de ideias radicais. Quantos discursos do bêbado de Pequenos Burgueses não induziam à violência, e embora eu, pessoalmente, não tivesse nunca professado, na prática e na ação, as mesmas ideias, não seria eu co- 
responsável pela opção de tantos jovens que se atiraram nos braços da morte? Não sei se parece radical assumir a responsabilidade que nunca me seria cobrada, num plano mais superficial ou materialista. (...) Mas não tenho dúvidas de que absolutamente tudo que nos acontece vai sendo definido no subsolo energético do teatro de operações e não no plano mais superficial dos acontecimentos." (ARAP, 1998, p. 168)

A possível influência de uma personagem de ficção, ou uma obra de arte qualquer, sobre as decisões pessoais ou políticas das pessoas do público é algo mais ou menos normal. Mas Fauzi inclui esse efeito no que chama de "subsolo energético do teatro de operações", em oposição ao "plano mais superficial dos acontecimentos", sugerindo o braço intangível do fluxo das influências. E considera possível, ou provável, que seu sucesso no papel de Tiêteriev tenha levado algumas pessoas a se juntar à luta armada. Seria uma influência negativa do teatro na sociedade, com implicações históricas que, no caso, o autor preferia não ter exercido. Mas em si, a influência efetiva do teatro na sociedade, ou de qualquer arte, é um desejo comum entre os artistas. Normalmente num sentido minimamente pacífico, o desejado "ouro alquímico" tende a ser algo que tem a ver com um interesse coletivo. Entre os artistas entrevistados no capítulo 3 deste estudo, Oficina Alquímica, é citado como a possível expressão de um "teatro da alquimia e alquimia do teatro" que se pode verificar num estágio mais consciente e desenvolvido. A maior Alquimia seria realmente a transformação coletiva, a contribuição do Teatro para a sociedade. Que sejam 500 pessoas, ao todo, assistindo ao conjunto de apresentações de uma peça, o símbolo bem aplicado na psique tende a funcionar e cumprir sua função transformadora numa progressão geométrica. Segundo o diretor daquela montagem de Pequenos Burgueses, José Celso Martinez Corrêa, a peça traz, intrínseca, a ideia de se "atribuir à vida cotidiana um sentido, uma direção, um ritmo dentro de sua aparente incoerência." E ainda, nela "os acontecimentos mais vulgares trazem em si, quer se queira ver ou não, o sangue das grandes conflagrações históricas." (CORRÊA, STAAL, 1998, p.54). Essa suspeita de um "sentido" subjacente à realidade, e de um significado macrocósmico implícito nos detalhes do cotidiano se revela no depoimento, as vezes nas entrelinhas, uma inquietação central na poética de Fauzi.

Se o teatro cumpre a função ideal da arte de promover a evolução do espírito humano, do operário da cena ao público, não é como qualquer arte, mas como a única, cuja materialidade só existe no contato humano direto e presencial. Contato entre forças anímicas que interagem significativamente, emocionalmente, sensorialmente, com emissores e 
receptores presentes fisicamente no mesmo tempo e espaço, potencializando a influência e assim ganhando força política:

(...) política e o teatro são, por natureza, duas formas muito poderosas de mobilização da paixão, e é claro que, somadas, conseguem multiplicar seu poder. Essa minha iniciação teatral particular acabou por fazer com que eu associasse a magia do palco e a luta política de forma quase irremediável.” (ARAP, 1998, p.33)

Desde o início, Fauzi faz seu teatro num contexto de forte acento político: "como a maioria dos universitários e artistas daquele tempo, eu também havia adotado uma filosofia materialista de vida, e me acostumara a tentar reduzir tudo a uma leitura política da realidade e dos fatos." (ARAP, 1998, p. 15). Mas sua expressão política parece focada no aperfeiçoamento do ser humano, com a consciência do coletivo mais humanista do que ligado a uma ideologia clara. Sua aventura subjetiva é simultânea e talvez tão intensa quanto a dos agentes diretamente políticos, mas de forma diferente, discordante e subversiva, mas hermética, por isso livre apesar do golpe de 64, da luta armada, do AI5, etc. Essa potência subversiva vingou com o tempo, mas o processo foi perturbador:

A bruta realidade da perseguição política parecia negar os meandros e sutilezas de
minha busca, demonstrando sua irrealidade. A violência da situação que envolvia
meus companheiros de teatro, muitos caçados pela polícia política, parecia dar-lhes
inteira razão na visão que tinham de mim. Eu, que de forma quase inocente
participara (de) trabalho norteado pelo Partido Comunista, ao qual eu não era filiado,
fui surpreendido por telefonemas anônimos e terroristas no dia seguinte a meu
rompimento com Antunes, nos quais uma voz enumerava nomes e se dizia um
daqueles operários que eu havia dirigido. A somatória de evidências palpáveis de que
a realidade material da Vida era principalmente política conseguiu paralisar qualquer
intenção que eu pudesse ter de prosseguir em minha investigação. (ARAP, 1998, p.
61)

Certamente a temporada de angústia foi fundamental no caminho do artista, mas também poderia não ter resultado em nada que prestasse. Os riscos assumidos por quem opta por esse tipo de entrega no teatro, tanto quanto na vida, foram conhecidos por Antonin Artaud, que escreveu sobre os velhos textos alquímicos:

(é) como se seus autores tivessem sentido desde logo tudo o que existe de representativo, ou seja, de teatral, na série completa dos símbolos através dos quais se realiza espiritualmente a Grande Obra, enquanto ela se realiza real e materialmente, e também nos desvios e digressões do espírito mal informado, em torno dessas operações e na enumeração "dialética", por assim dizer, de todas as aberrações, fantasias, miragens e alucinações pelas quais não podem deixar de passar os que tentam essas operações com meios puramente humanos. " (ARTAUD, 2006, p. 50)

A transformação de um ser humano submerso num estado nervoso e psicológico absolutamente caótico num ator capaz de uma performance absolutamente primorosa - 
poderia ser um reflexo, não linear e não causal, de todo o conhecimento e sabedoria específica de homem de teatro que ele veio a alcançar posteriormente, ao longo de suas várias décadas de atividade. E nessa transformação, desprovida de qualquer lógica, linearidade ou causalidade, entre outras coisas, estaria uma das faces do que Fauzi veio a chamar de Alquimia do Teatro.

Inverificável, essa dinâmica atemporal não esgotaria uma definição da "alquimia do teatro" vislumbrada por Fauzi. As reflexões abrem caminhos tão abundantes quanto raros. O que fica indelével é a ideia da transformação. Naquele momento de sua vida de ator, por fora ele conhece a glória, mas por dentro a alma grita por transformação. Ele cai, de um estado de êxtase perene, para o inferno solitário da ausência de uma epifania impossível, no centro das atenções, no papel de um ator famoso desajustado atingido pelo ácido. Uma situação bem difícil, considerando os tempos, começo dos anos 1960, uma época em que o conceito de "caretice" ainda não tinha sido formulado por falta de quorum entre os que dele se distinguiam.

\section{CATÁBASE 1}

No vácuo do sucesso com Pequenos Burgueses, Fauzi foi convidado pelo diretor Flávio Rangel ${ }^{29}$ para atuar na produção da peça $A$ Sinistra Comédia, de Harold Pinter ${ }^{30}$, com grandes nomes do teatro tradicional, Ítalo Rossi, Rosita Tomás Lopes, Celia Biar e Napoleão Muniz Freire, quando percebeu que não se encaixaria no esquema padrão do teatro profissional da época:

Decidi aceitar, já que meu dinheiro ia acabando e eu pretendia permanecer no Rio, e sem um trabalho seria impossível continuar morando lá. (...) pareceu uma oportunidade excelente para que eu consolidasse meu rumo como ator profissional e indivíduo, já divorciado dos grupos Oficina e Arena. Já nas primeiras leituras, o

\footnotetext{
${ }^{29}$ Flavio Rangel (1934 / 1988) Diretor teatral, cenógrafo, jornalista e tradutor brasileiro, premiado em 1958 pela Associação Paulista de Críticos de Teatrais por sua direção da peça "Juventude Sem Sono", de Michael Vicente Gazzo. No ano seguinte dirige "Gimba, o Presidente dos Valentes", de Gianfrancesco Guarnieri, com Maria Della Costa, que estreia no Teatro Popular de Arte, e depois é encenada em Portugal, Roma e Paris. Em 1960, torna-se o primeiro diretor brasileiro a frente do Teatro Brasileiro de Comédia, companhia fundamental do teatro brasileiro na década de 50. Foi casado com a atriz Ariclê Perez. Em 54 anos de vida, teve significativa produção jornalística e dirigiu mais de 80 espetáculos, entre peças de teatro, shows musicais, desfiles de carnaval e até desfiles de moda.

30 Harold Pinter (1930 / 2008) Dramaturgo, roteirista, poeta, diretor e ator inglês. Prêmio Nobel de Literatura 2005. Entre outros prêmios, ganhou o Wilfred Owen Prize por sua obra poética contrária ao conflito do Iraque. Escreveu 29 peças encenadas, 21 roteiros para filmes de sucesso e dirigiu 27 produções teatrais.
} 
desconforto que senti foi desproporcional. As belas vozes, muito bem colocadas, dos outros atores conseguiam mobilizar em mim uma insegurança tamanha, que me levou a duvidar de minha capacidade como ator. Eu chegava a suar frio, sem entender o que estava acontecendo (...) chegava a me parecer que eu não era ator, que nunca tinha sido, e que tudo não passava de um equívoco. (...) talvez todo malestar pudesse ser resumido no fato de eu não desejar trabalhar daquela forma, ou pelo menos não saber. A questão é que eu estava descobrindo que nunca poderia ser um ator apenas profissional. (ARAP, 1998, p.87)

Fauzi era um ator apaixonado, difícil imaginar que abandonasse o ofício sem algum motivo da mesma intensidade. A mesma paixão fez dele diretor, mas a escolha da morte revela uma dinâmica específica.

Da mesma forma que no mito, Dioniso ainda é chamado Zagreu quando morre pela primeira vez, desmembrado e devorado por Titãs (figuras mitologicas que simbolizam, na psicologia analítica, os aspectos regressivos da psique), também o ator Fauzi Arap morreu, a seu modo, desmembrado e devorado pelos Titãs como símbolo do mal confinado nos abismos da alma:

Tive de enfrentar uma enorme solidão por destoar das palavras de ordem do grupo, e muito me custou até aprender a discernir entre a expressão verbal de certas ideias, com o decorrente debate intelectual que elas suscitam, e outras que se revelam apenas no silêncio e nas entrelinhas do que se fala ou se escreve. Não percebi, num primeiro momento, quanto minhas descobertas contradiziam toda a filosofia de vida de meus companheiros (...) Eu estava buscando uma forma de integrar os dois mundos (...) que não me obrigasse a uma ruptura. (ARAP, 1998, p.43)

Os Titãs surgem projetados na reação da sociedade a seu vislumbre de uma realidade estranha, libertária, talvez pressentida, mas inconscientemente temida. Reação manifesta, talvez, na própria atitude do psiquiatra, sem julgamento, considerando a sinuca de bico que deve ter surpreendido o médico depois de alguns anos ministrando esse tipo de tratamento experimental, quando the aparece um paciente como Fauzi:

(...) depois de todo um inicio arrasador, minhas últimas sessões com Murilo aconteceram num clima de desconfiança recíproca, viciosas desde o inicio. Uma subterrânea desconfiança e a ansiedade que ele deveria sentir em conduzir-me a um porto seguro devem ter colaborado. Imagino que ele deve ter sido pressionado a explicar meu comportamento estranho, e, quem sabe, também o de outros pacientes, que desconheço em detalhes. (ARAP, 1998, p.56)

A mesma reação se manifesta na ação daqueles que destruíam a integridade do artista duvidando de sua saúde mental quando ele perdeu o controle da terapia, entre 1964 e 65 . Fauzi viveu o paradoxo: o mesmo entusiasmo libertador que fertilizava seu gênio inspirava o desprezo de quem não entendia nada que ele dizia: "Eu não percebia o quanto aquele estado de sintonia com o invisível, que eu tanto desejava manter, era o antípoda do debate intelectual 
em que acabava me envolvendo, ao tentar repartir o que apreendera" (ARAP, 1998, p.57) Ninguém entendia nem perdia a chance de fixar um tijolo no muro do estigma que o apertava na temporada 1964 / 1965.

Diz a mitologia que os Titãs "comportam-se como Mestres de iniciação, no sentido de que matam o neófito, a fim de fazê-lo "renascer" numa forma superior de existência" (ELIADE, apud BRANDÃO, 1987, vol.II p.119) Se o processo de morte do ator e renascimento do diretor foi para Fauzi uma ascenção a uma "forma superior de existência", nunca saberemos como seria se ele seguisse a carreira de ator, aceitando papéis diversos, fazendo novelas etc. Mas observamos a qualidade do artista que ele se tornou, conforme sua própria escolha. Uma escolha difícil, um pouso forçado; uma improvisação num roteiro previsível para um jovem ator de sucesso. Podia ter sido um colapso.

A “solidão" de Fauzi por não repetir "as palavras de ordem”, por contradizer a filosofia geral e por querer integrar os mundos, na verdade, talvez nunca tenha passado. Tudo que Fauzi tentou dizer naquela época mas ninguém entendia, ou pelo menos uma parte, está formulada no depoimento publicado nos anos 1990, mas já com outras perspectivas, certamente diferentes das dos anos 1960. E ainda escritas de forma reservada, tocando sem tocar em questões herméticas, diferente do texto em prosa poética no programa do show Rosa dos Ventos, mas ainda essencialmente subversivo. A outra parte do que ele não pôde comunicar, saberemos menos ainda, porque seria realmente o inefável. Mas podemos investigar, seguindo os passos de Fauzi, observando os fatos como se fossem símbolos.

Uma percepção simbólica das coisas pode acontecer de forma arrebatadora, numa reação em cadeia, inspirando opções radicais pela poesia como valor absoluto, como aquela feita por escritores e profetas que se retiram do mundo para dar conta de uma obra que inviabiliza a normalidade. Ou como Fauzi quando fechou a conta como ator. Não se retirou do mundo mas saiu fisicamente de cena, talvez para dar conta de uma obra que precisava dessa morte para renascer em sua potência específica.

A sincronicidade de toda sua transformação pessoal com a terapia faz sentido. E acusa a potência transformadora de uma ampliação da percepção a um grau tão imenso e urgente quanto incomunicável, um choque de percepção, intenso e radicalmente diferente, inusitado, um acontecimento fora da curva para alguém como Fauzi, que acabou definindo toda sua trajetória. 
Talvez Fauzi intuísse um colapso mais grave, uma implosão que viria da aplicação radical do grau de sensibilidade e liberdade mental, e talvez emocional que ele tinha alcançado, na função do ator, que tem no corpo a principal ferramenta. Talvez ele sentisse que podia ficar realmente louco, ou talvez tenha simplesmente preferido sair de cena e trabalhar nos bastidores para poder sobreviver ao estigma que o atacava, depois de ter sua sanidade mental questionada e sua figura pública transformada em tema de falatórios no meio artístico.

Pouco depois da participação em Pequenos Burgueses, Fauzi atua em outra peça, cujo título - diante da sensação descrita por ele, de total inadequação social - parece uma “coincidência significativa” levemente sádica: O Inoportuno. Montagem do Grupo Desisão ${ }^{31}$ Com texto também de Harold Pinter, direção de Antônio Abujamra ${ }^{32}$, e os atores Emilio di Biasi $^{33}$, Sérgio Mamberti ${ }^{34}$ a Fauzi no elenco. Num contexto em que se fala de um tempo não linear, chama atenção que os acontecimentos narrados por Mamberti, na conversa sobre o exparceiro, tenham se dado antes dele aceitar o convite para integrar o elenco de Flávio Rangel em A Sinistra Comédia.

As cenas descritas revelam, além do pensamento excepcional por trás da forma de Fauzi atuar e pensar o teatro, como o que parece ser o momento em que o ator rompe o laço emocional com a profissão e decide não mais ser ator - em mais um caso de "coincidência signficativa", já que o nome do grupo em que atua na ocasião é “Grupo Decisão". Depois,

\footnotetext{
${ }^{31}$ Grupo Desisão (1963 / 1966) coletivo teatral atuante em São Paulo e Rio de Janeiro, comandado pelo diretor Antônio Abujamra. Nasce da associação do diretor com Antônio Ghigonetto e Emílio Di Biasi, em busca do teatro socialmente engajado. Formado ainda por Berta Zemel, Wolney de Assis e Lauro César Muniz, o grupo desenvolve importante atuação na cena teatral, honrando a formação do diretor, recém chegado de estágios na França, no Théâtre National Populaire, e na Alemanha, no o Berliner Ensemble de Brecht, e buscando popularizar um teatro artístico e culturalmente relevante.
}

32 Antonio Abujamra (1932 / 2015) Diretor e ator premiado e comunicador paulistano, foi pioneiro na aplicação dos princípios e métodos teatrais de Bertolt Brecht no teatro brasileiro, como também de Rogelnikr Planchon e outros mestres da contemporaneidade. Nos anos 1980 e 1990 trabalhou como ator de novela na Rede Globo de Televisão. A partir do ano 200 assume a frente de um programa de entrevistas fundamental na história da TV brasileira, "Provocações", produzido e exibido semanalmente pela TV Cultura de São Paulo até 2015.

${ }^{33}$ Costabile Emílio Di Biasi (São Paulo,1939) ator e diretor, estréia em José, do Parto à Sepultura, texto de Augusto Boal, dirigido por Antônio Abujamra para o Teatro Oficina, em 1961. Um dos fundadores do Grupo Decisão, com importante atuação na cena teatral dos anos 1960. Nos anos 80 atua no cinema em filmes de Carlos Reichembach e a partir dos anos 90 torna-se diretor e co-diretor de novelas e mini-séries na Rede Globo de Televisão.

${ }^{34}$ Sérgio Mamberti (Santos SP 1939). Ator e produtor formado pela Escola de Arte Dramática da USP, presença marcante no teatro brasileiro desde os anos 1960, e também no cinema e TV. Em 1963 Integra o Grupo Decisão; em 1969 é premiado pelo papel de Juiz na montagem de O Balcão, de Jean Genet, dirigido por Victor Garcia. Ator constante em produções de prestígio, dirige o extinto teatro Crowne Plaza, em SP, promovendo talentos e experiências cênicas originais. Como gestor cultural foi Secretário de Música e Artes Cênicas; Secretário da Identidade e da Diversidade Cultural; Presidente da Fundação Nacional de Artes e Secretário de Políticas Culturais. 
com a cabeça fria, quando aceitou o convite de Flávio Rangel, ele deve ter ponderado que não

precisava ser tão radical. Mais tarde, viu que precisava, sim. Sem dúvida, o ex-parceiro captou

um momento em que a ideia de matar o ator firmou um ponto na alma do artista, na fúria de

uma espécie de indignação intensa, mas de nexo complexo:

SM - Eu fiz a última peça dele como ator, O Inoportuno. É quando ele resolve não fazer mais [como ator].1964... Era uma peça do Pinter, tudo em cima de subtextos, um ambiente de incomunicabilidade... O Pinter era um dos autores dessa ausência, dessa impossibilidade de comunicação no mundo moderno, cada um no seu casulo e essa impossibilidade de se comunicar profundamente. A peça é um menino que já teve problemas psiquiátricos, talvez esquizofrenia, não fica claro, e ele encontra um velho, um bum, na rua, um clochard que não tem onde morar. E convida pra ir na casa dele. (...) E vai se apossando da casa, entendeu? No final do primeiro ato ele já está dono da casa. O rapaz sai e ele fica sozinho, aí chega o meu personagem, torce o braço dele e fala: 'O que você tá fazendo aqui? Eu sou irmão do cara.' Aí o velho: 'Pô, me fodi.' Entendeu? Era um personagem extremamente agressivo, e foi o primeiro grande papel da minha carreira, eu ganhei todos os prêmios esse ano. E aconteceu uma coisa muito especial nesse momento, uma coisa que marcou minha vida. O Fauzi era esse velho. Terrível, porque, ao mesmo tempo em que ele é todo desprotegido e tudo, de repente ele invade mesmo. Mas eu não conseguia chegar a uma síntese do meu personagem. Eu estava trabalhando, vamos dizer, com as ferramentas que eu tinha, mas era um personagem, em primeiro lugar, extremamente agressivo, que não é o meu temperamento; e fisicamente forte, e eu era frágil, fisicamente. Então eu comecei a ver o personagem de fora. Fui pra estrada, peguei carona de caminhão pra entender como que é. Eu morava em Santos e ia de caminhão pra entender o que é um caminhoneiro, como o caminhoneiro se relaciona com o mundo, com as coisas, o tipo de sensibilidade. E nós estávamos na semana de estreia, o Fauzi já estava bem encaminhado no personagem, porque ele tinha um solo para percorrer. Tinha nuances e tudo, mas tinha um chão. E o Emilio também. E o meu personagem estava tudo certo, mas não existia. Estava vazio. Eu numa angústia, horrível. (...) Aí o Fauzi falou assim: 'Eu sei porque [o personagem não existe]. [E eu perguntei:] 'Porque, Fauzi?' [E ele:] 'você não percebeu que o Mic é você. (...) você não precisa fazer nenhum esforço para ser o Mic porque, por definição, você é o Mic. Entendeu? (...) Aí, foi.

Sérgio Mamberti fala sobre processo alquímico de Fauzi:

SM - Fundamentalmente, pra ele, era um sofrimento muito grande. O processo de criação e a presença no palco, era uma coisa, um sofrimento que deixava ele num estado alfa meio complicado. Aí entra esse processo alquímico que ele fala. Era muito presente. E isso tinha uma reverberação emocional também, em tudo. Tem que entender que o Fauzi era uma pessoa com um grau de sensibilidade fora do padrão, um grande criador mesmo. No dia da estreia, foi um sofrimento porque era uma coisa que ele não queria fazer, uma coisa artificial, vamos dizer, que era o bigode. $\mathrm{E}$ de repente o Abujamra falou: 'Não quero saber, tem que ter bigode.' E ele não tinha deixado crescer o bigode, então botou um bigode que o maquiador do TBC, o velho Leontij Timoszczenko ${ }^{35}$ fez pra ele. E no final do espetáculo, na estreia - foi no Oficina que nós fizemos - caiu o bigode dele. Ele não queria usar esse bigode postiço, mas o Abujamra obrigou. E o bigode caiu, porque suava. 3 horas de espetáculo, caiu. Bicho, isso, pro Fauzi, foi... basta dizer que eu fui abraçar ele e, pá, teve uma coisa assim, de raiva: 'Sai! Sai!'... Bem o jeito do Fauzi. Eu falei: 'Fauzi, mas você foi maravilhoso.' Ele: 'Não! Não! Não! Nunca mais vou ser ator. Não quero mais ser ator.' E ele saiu do Inoportuno. (...) Era como um nervo exposto. A

\footnotetext{
${ }^{35}$ Leontij Timoszczenko (Ucrânia, 1913 / Brasil, 19-) ator, maquiador, pintor e professor, trabalhou como ator e maquiador no Teatro Brasileiro de Comédia e também em produções de Cacilda Becker, Antônio Abujamra e outros
} 
intensidade foi tão grande, eu vi o sofrimento dele. Mas, na verdade, isso já vinha dentro dele. Era um processo. Todos nós, de uma certa maneira, tivemos questionamentos nesse nível. O Oficina e tal, cada um de um jeito. Só que o Fauzi foi um precursor. E ele colocava isso muito na primeira pessoa. Então não dá pra fazer teatro de faz de conta. Tem que ser: 'Sérgio Mamberti é Mic.' É isso. É esse toque que ele me deu: não tem como você fugir de você mesmo. (...) Ele não era um ator comum, ele era um grande ator. Não era um cara mais ou menos que deixou de ser pra fazer outra coisa. Não. Era um ator protagonista, um grande ator. (...) É um nível de sensibilidade que está além da sensibilidade do intérprete, entende, é um grau a mais. Por isso que cria essa sensação de ser uma coisa alquímica e transcendental. Porque, de repente, você chega num nível que não é mais só o trabalho artístico, você passa a se comunicar num outro plano. Um plano muito transcendental. Mas insuportável. A sensação é que era um estado de sensibilidade tão agudo que era insuportável, então ele preferiu filtrar isso virando diretor e autor, onde ele não estaria pessoalmente se expondo tanto, e sofrendo tanto.

\section{ANÁBASE}

Em seu estudo sobre Dioniso, o mitólogo Junito Brandão afirma que "a "morte" de Dioniso nada mais é que uma catábase seguida, de imediato, de uma anábase.” (BRANDÃO, 1987, p.118). O deus é assim associado a um outro tipo de figura mitológica, o herói, um mortal, que tem na catábase e na anábase etapas típicas da constituição básica de suas narrativas míticas. Catábase significa uma descida ao mundo dos mortos, empreendida pelo herói para realizar alguma tarefa cósmica; mas para que seja uma catábase, ele precisa realizar a outra grande tarefa de não morrer no mundo dos mortos, e voltar vivo para o mundo dos vivos. Numa analogia com a trajetória de Fauzi, ele teria voltado super vivo.

Em 10 de dezembro do mesmo 1965, a meses dentro daquela angústia toda, Fauzi dá seu nó em pingo dágua e estreia como diretor com a montagem de Perto do Coração Selvagem, adaptação sua para textos de Clarice Lispector ${ }^{36}$.

Considerando a trajetória, foi uma jogada de mestre que ele não previu, na verdade. Era pra ser uma produção amadora. Fauzi nem a considera mesmo sua primeira direção profissional, que situa em Dois Perdidos numa Noite Suja, de Plínio Marcos, em 1967. Mas hoje a adaptação de Clarice, que teve José Wilker, Glauce Rocha, Dirce Migliaccio e o próprio Fauzi no elenco, virou um acontecimento histórico: primeira adaptação de Clarice, uma das primeiras adaptações de literatura no teatro brasileiro, com soluções formais originais. $\mathrm{Na}$ época, foi sucesso de crítica em matérias de capa. Bem mais importante que isso foi o

\footnotetext{
${ }^{36}$ Clarice Lispector (1920 / 1977) Uma das maiores escritoras e poetas da terceira fase do modernismo brasileiro, chamada de "Geração de 45", recebeu diversos prêmios dentre eles o Prêmio da Fundação Cultural do Distrito Federal e o Prêmio Graça Aranha. Nasceu na Ucrania, na cidade de Tchetchelnik. Fugindo da perseguição aos judeus durante a Guerra Civil Russa (1918-1920), seus pais chegaram ao Brasil em1921 trazendo a pequena Chaya Pinkhasovna Lispector, que teria seu nome mudado para Clarice Lispector.
} 
processo interno que levou Fauzi a querer adaptar os textos da escritora para o teatro. A leitura do livro "A Paixão Segundo GH" (base da adaptação para o teatro, com trechos de outros livros) foi um encontro determinante no processo de resgate do próprio prumo que Fauzi precisou empreender. A literatura de Clarice teria sido a fagulha libertadora que possibilitou seu renascimento. "Desde as primeiras linhas, A Paixão se anunciava como um encontro salvador" (ARAP, 1998, p.67) De fato, pelo depoimento, as palavras de Clarice poderiam ter sido escritas por ele naquela mesma época: "estou procurando, estou procurando. Estou tentando entender. Tentando dar a alguém o que vivi e não sei a quem, mas não quero ficar com o que vivi. Não sei o que fazer do que vivi, tenho medo dessa desorganização profunda." (LISPECTOR apud ARAP, 1998, p.67)

A Paixão Segundo G.H. foi publicado em 1964, ano do Golpe Militar, ano em que Fauzi vive o auge e a queda do tratamento com LSD e no ano seguinte faz seu grande papel em "Pequenos Burgueses", de Máximo Górki, em temporada do Oficina no Rio de Janeiro. Ou seja, vivendo praticamente no mesmo tempo-espaço, a escritora narra a angústia da personagem no desejo de compartilhar uma experiência desestruturante, incompreensível e incomunicável, parecida com a descrita por Fauzi em seu depoimento: "não me conformava por ter me perdido tanto de mim. (...) no camarim eu costumava, como desabafo, escrever. Eu tentava cegamente me socorrer das palavras, já que ia descobrindo que toda experiência lisérgica parecia não caber na minha vida”. (ARAP, 1998, p.67)

Nessa investigação e dramaturgia em processo amigo da metáfora, o encontro de Fauzi com Dr. Murilo e sua terapia se parece com o que o mitólogo Campbell considera um “chamado à aventura”, padrão na trajetória estudada no tratado O Herói de Mil Faces. E o encontro com Clarice seria a etapa seguinte do ciclo, o "encontro com o Mentor":

\footnotetext{
Não consigo ver $A$ Paixão Segundo G.H. apenas como literatura (...) o livro não passa do relato da viagem essencial dela mesma (...) Ao capturar o registro essencial de uma mudez de alma como a que vive sua personagem, Clarice acabou ultrapassando os parâmetros da cultura e da estética, para estabelecer uma verdadeira revelação. Apesar de disfarçada de "arte", para mim, A Paixão não passa de um relato iniciático." (ARAP, 1998, p.73)
}

Fauzi declara a influência da escritora e a contemplação de sua arte e postura como o movimento que dissolveu seu silêncio e ensinou um salto de compreensão e de capacidade de ação no mundo, multiplicado pelo desejo de montar os textos dela no teatro: 
O alívio que a leitura do livro me trouxe, eu não soube explicar (...) surpreendente como aquele livro retratava minha própria viagem lisérgica, de forma elegante e completa. Para mim, desde o início, não se tratava de literatura, mas quase de um milagre (...) como se a literatura de Clarice tivesse me devolvido a identidade que eu perdera, ou tivesse o dom de reintegrar em mim aquilo que, mesmo sem querer, eu não conseguia apagar de minha memória - as experiências fantásticas que vivera. Ela chegava para acabar com minha decisão de calar" (ARAP, 1998, p.67)

Para além da contemplação da arte de Clarice, para Fauzi a experiência de transformar seus textos em teatro, se compara a uma operação alquímica, no sentido psicológico: Coagulatio, ou "o processo que transforma as coisas em terra" (EDINGER, 1995, p.101). Quando o abstrato vira concreto, ganha forma e posição fixa, em termos psicológicos, algo "ligado a um ego". Quando Fauzi desejou transformar Clarice em teatro, foi pai e filho do que se tornou como artista:

(...) tendo contemplado com secreto desejo a tentação do corpo e de sua 'vida', dita na terra, a alma, pelo próprio peso disso faz seu pensamento voltado para a terra afundar gradualmente na direção do mundo inferior... Em cada esfera (por que passa) é revestida por um invólucro etéreo, pelos quais se reconcilia, por etapas, com a companhia de suas vestes terrenas. E assim é que ela passa por tantas mortes quantas são as esferas que percorre quando se dirige para aquilo que, na terra, é chamado 'vida'. (MACROBIUS, apud EDINGER, 1995, p.106)

As percepções inefáveis de Fauzi e suas evoluções seriam como a alma de sua arte a caminho da encarnação. E os invólucros etéreos através dos quais suas percepções se reconciliam com as vestes terrenas seriam: a libertação interna, o entusiasmo com estas percepções, a angústia pela impossibilidade de comunicação direta da experiência, e o processo criativo detonado por esse entusiasmo e essa impossibilidade. Uma impossibilidade que age como o arquétipo do incesto na gênese psíquica, a relação impossível que define todas as outras relações.

O Anatomia da Psique lembra Fausto aprendendo com Mefistófoles, aquele que "No princípio era a proeza”. (GOETHE, Fausto, pt. 1, verso 1237 apud EDINGER, 1995, p. 103) significando que a "atividade e o movimento psíquico promovem o desenvolvimento do ego. A exposição à tempestade e à tensão da ação, a batedura da realidade, solidifica a personalidade." Assim, o processo teatral que levou as palavras de Clarice à cena teria feito o papel da "batedura" necessária para que essa influência fecundasse definitivamente a alma do diretor que nascia naquele espetáculo, e do dramaturgo que nasceria 10 anos depois com Pano de Boca.

Mais do que uma influência de estilo ou de um sistema de pensamento, a arte de Clarice para Fauzi pode ter sido um modelo de libertação. A imagem do salto que ele não 
tinha cogitado. O ovo de Colombo: criar como Clarice criava, falando daquela realidade extraordinária que ele também conhecia mas na sua boca virava uma nebulosa confusa. No texto e na atitude da escritora ele compreendeu a dinâmica da liberdade e da lucidez extrema que a matéria etérea pedia para ser codificada, e só a linguagem esteticamente trabalhada poderia dar conta de comunicar. Talvez, naquele momento, um salto longo demais para uma conclusão funcional a partir de uma perspectiva puramente mental. Como Fauzi tinha pressa, acessando uma sabedoria alquímica inconsciente, teria agido para internalizar o salto de consciência na "batedura" do processo de montagem da peça. Dizia o pré-socrático Anaximandro que "o mundo foi coagulado vindo a ser, mediante um movimento de agitação ou de batedura: "Há um eterno movimento, no qual se produziu a origem de todos os mundos." (BARNET, apud EDINGER, 1998, p.102). Concebia-se esse "eterno movimento" como um vórtice que se manifestava no "ilimitado" (apeiron), a prima matéria" (EDINGER, 1998, p.102). O teatro seria um reflexo humano desse eterno movimento, o vórtice manifesto

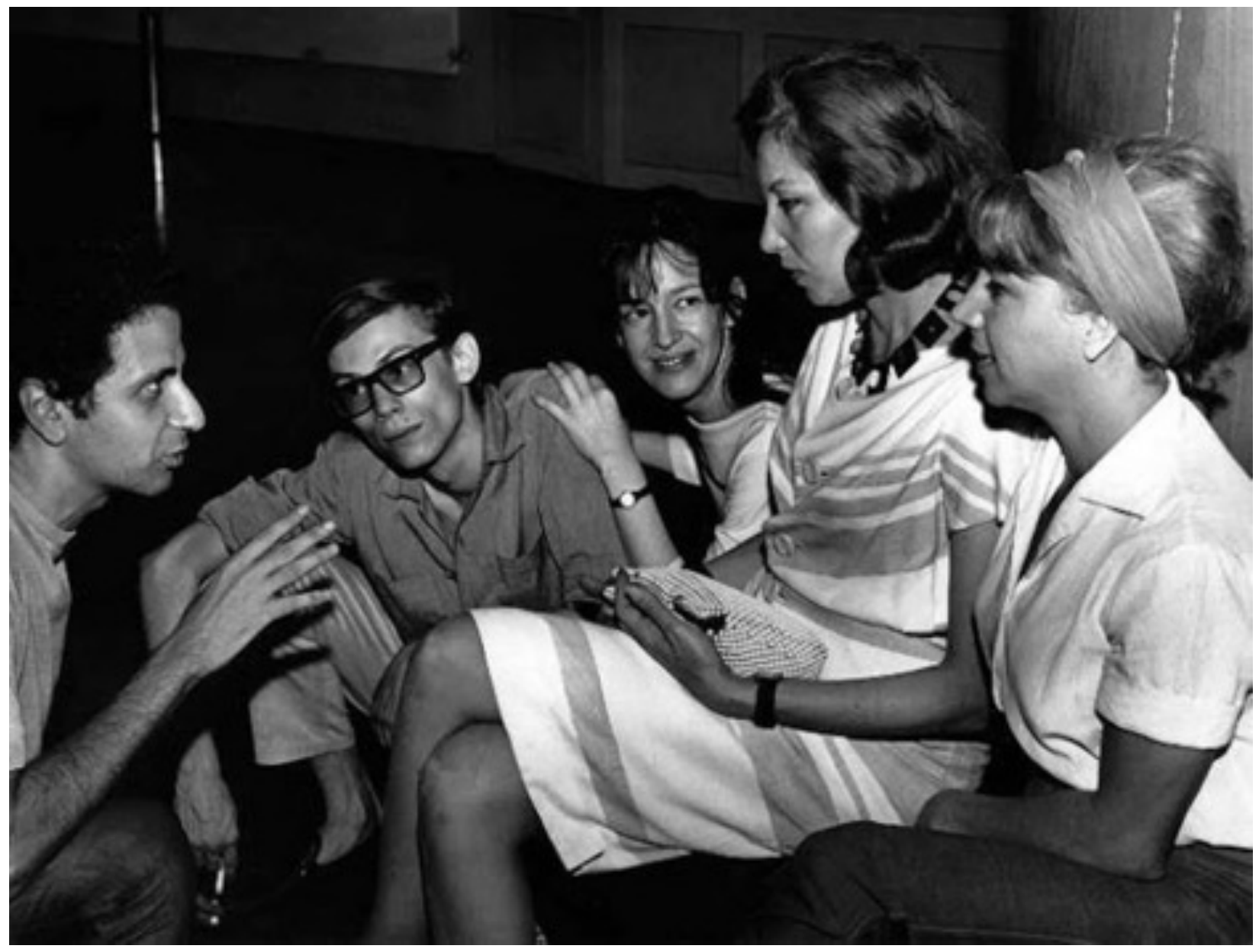

Clarice Lispector conversa com elenco da peça "Perto do Coração Selvagem”, 1965. 
no trabalho do ator, que estabelece o jogo ilimitado das relações humanas como a Prima Matéria, que possibilita o trabalho alquímico. Para Fauzi, esse entendimento começou pelo cuidado com a fala, no trato das relações humanas: "acabei aprendendo com ela (Clarice) todo um cuidado com a linguagem, e principalmente com o ouvinte, para não ser traído pelas palavras, e conseguir assim ultrapassar a difícil barreira das subjetividades." (ARAP, 1998, p. 67) Do trato nas relações até a experimentação cênica da literatura, o foco se define na linguagem, ou no caminho do conteúdo inefável até sua expressão no mundo, que compõe a expressão total de qualquer abstração na matéria: "Eu flagrara no livro um núcleo dramático a dificuldade de expressar o inexprimível, e o conflito entre dizer ou não, que estava estruturalmente presente em todo o corpo do livro. Sem dúvida, aquele era meu próprio drama particular naquele momento" (ARAP, 1998, p.67)

Uma bela transmutação, na verdade: num momento, Fauzi interrompe subitamente uma notável trajetória de ator, perdido em crise com o ofício, perturbado por falatórios sobre sua saúde mental; no momento seguinte, se efetiva rapidamente num novo nível de criação, não mais intérprete, mas criador original, dramaturgo e diretor de uma peça histórica, parceiro de uma escritora já consagrada, ainda não como hoje, uma das grandes artistas de seu tempo. Montagem que era para ser algo discreto, amador, sem pretensão:

(...) uma temporada de dez dias, já que aquele não era mesmo um espetáculo profissional (...) como presente de estreia, ao meu ouvido, Clarice me segredou a coincidência - aquele era também o dia de seu aniversário. Acabamos merecendo as duas primeiras páginas inteiras dos segundos cadernos dos jornais mais importantes do Rio, o que não era normalmente concedido nem mesmo às grandes estrelas do teatro. (ARAP, 1998, p.)

Além das matérias de estreia, a resposta à montagem, segundo Fauzi, parece ter sido excelente. Antônio Abujamra estava lá e disse, sobre Glauce Rocha, que o diretor "conseguira torna-la uma deusa" e Fauzi relata a entrega da atriz:

O espetáculo era mobilizador de uma força estranha. Não era raro Glauce terminar a representação com febre (...) sua entrega era tamanha que não duvido de que a febre tivesse um outro tipo de origem que não física. O teatro não é brincadeira, quando é feito com verdade e aborda temas mobilizadores do inconsciente coletivo." (ARAP, $1998, \mathrm{p} . .$. )

Outras figuras presentes se manifestam: Oto Lara Resende se diz enlevado pela atmosfera sagrada; Millôr Fernandes é repreendido por "rir, acertadamente, em certos momentos"; Tonia Carrero só reclama por ser "pega sem sapatos" pela inovação da luz que se 


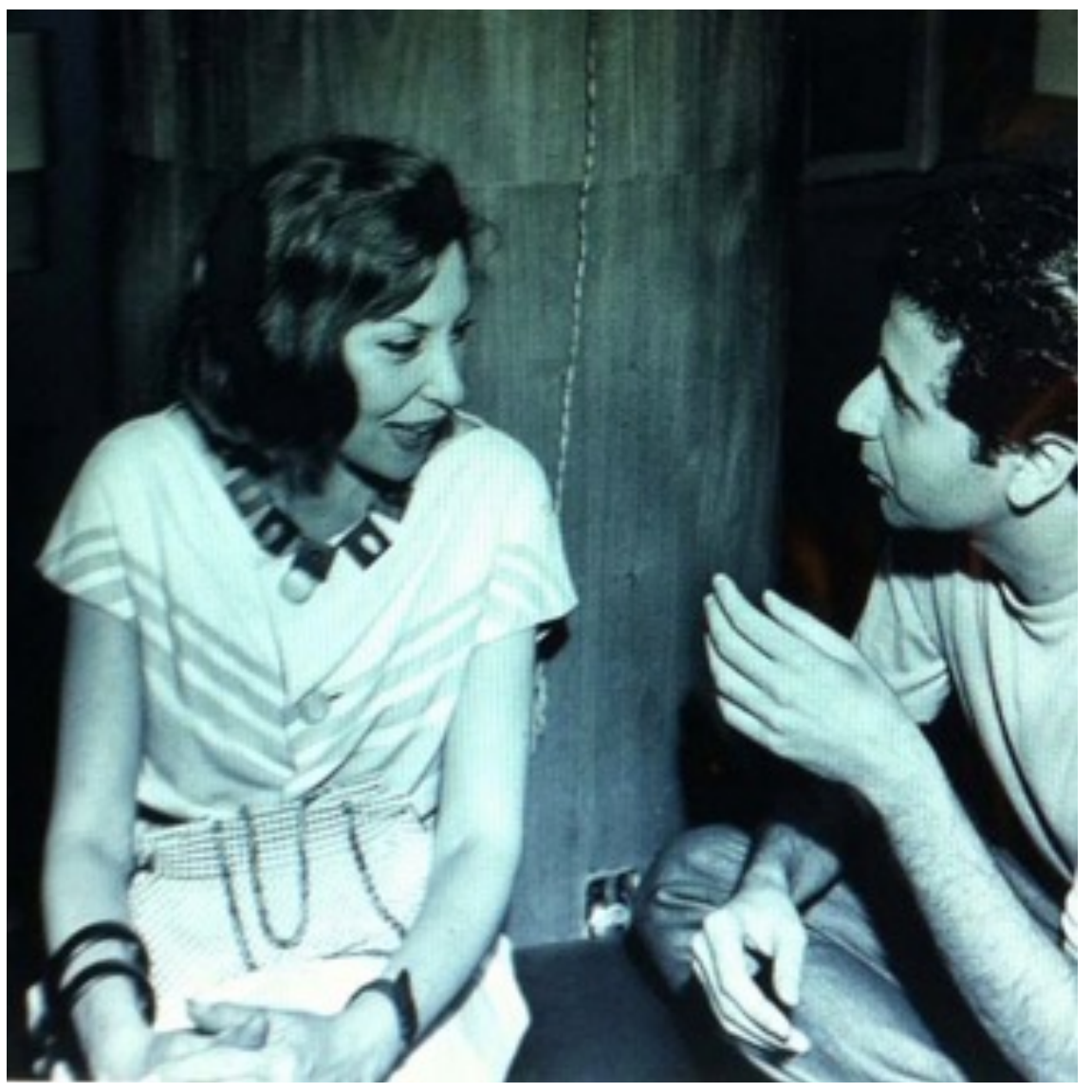

acende na plateia numa certa cena... (ARAP, 1998, p.69). O público é de gente exigente, esperando pelo melhor, principalmente a própria escritora, Clarice Lispector, que se expõe aos cuidados de um estreante. E Fauzi passa no teste, e se legitima como diretor. Uma vitória definitiva de um herói com muito trabalho pela frente.

\section{GUERRILHA SUBJETIVA}

Depois dessa estreia, ele só confirma seu gênio. Desenvolve-se um artista inovador, questionador, visionário. Mais uma vez, honrando o arquétipo do deus que fundou sua arte, segundo o mitólogo: a "transformação", operada no homo dionysiacus pelo êxtase e pelo entusiasmo (...) levava inexoravelmente a romper com todos os interditos de ordem política, social e "religiosa", ela, ipso facto, ia de encontro aos postulados da pólis" (BRANDÃO, 1987, vol.II, p.130). E Fauzi tanto quis romper com os interditos "de ordem política, social e "religiosa" que teve, em 1968, uma peça censurada com estardalhaço, Santidade, direção de Fauzi para o texto de estreia do dramaturgo José Vicente. O crítico Yan Michalski comenta em seu livro O palco amordaçado: 15 anos de censura teatral no Brasil que o presidente Costa e Silva comenta na televisão a imoralidade de Santidade e distribui pessoalmente cópias da peça aos donos dos principais jornais do país, pedindo que se manifestassem a respeito. O general chama a peça de exemplo do espetáculo que jamais seria encenado no Brasil. Nem por isso, Fauzi ou José Vicente vão parar nos porões do DOPS, como muitos artistas seus 
contemporâneos, talvez porque o teor político da peça, apesar do escândalo, fosse inacessível para censores ainda incapazes de definir a força política na história de um ex-seminarista michê que encontra o irmão padre para impugnar sua vocação religiosa. Pelos valores da Contracultura, ter uma peça censurada dessa forma espetacular equivaleria a uma medalha, quase a anti-consagração de um anti-herói. Fauzi milita poeticamente, sem siglas ou bandeiras. Não se envolve na disputa especificamente política mas, na prática e nas ideias, empreende certa guerrilha subjetiva, corrosiva da moral e dos bons costumes, libertária pelo caminho da poesia de viés psicológico.

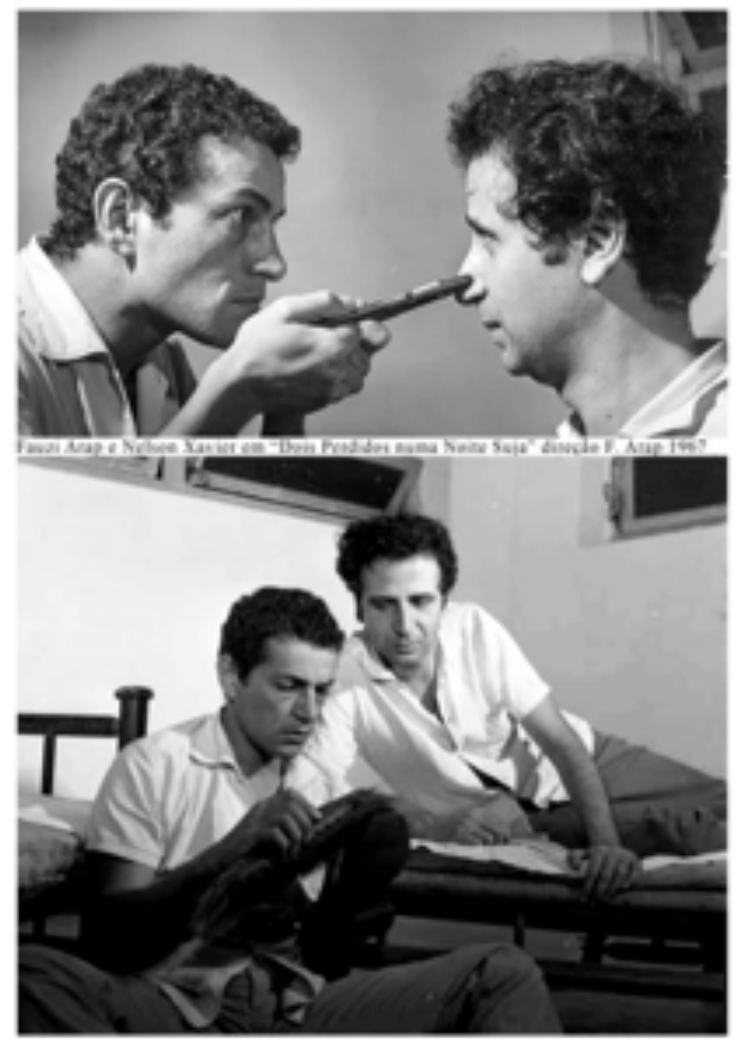

Foi o diretor que primeiro soube revelar a grandeza na dramaturgia de Plínio Marcos, tendo dirigido a si mesmo, junto ao ator Nelson Xavier, em Dois Perdidos Numa Noite Suja, em 1967 sua derradeira atuação no teatro. Mais tarde, no mesmo ano, dirige Navalha na Carne, também de Plínio Marcos, na segunda montagem da peça, no Rio de Janeiro, produção encabeçada por Tônia Carrero, rapidamente censurada, mas ainda considerada pela crítica um ponto alto na experiência teatral brasileira. $\mathrm{Na}$ época, o crítico Yan Michalski ${ }^{37}$ escreve: "A impiedosa autenticidade psicológica dos personagens (...) a extrema densidade do clima (...) uma peça à qual se assiste com a respiração presa, e a cujo fascínio não escapa nem o público mais conservador, a priori menos disposto a enfrentar cara a cara a crueldade e a violência". (MICHALSKI, 2005. p. 97) Tônia Carrero faz história com seu papel, considerado um dos grandes de sua carreira, interpretado com força realista desconcertante, e talvez confusamente bela no retrato da decrepitude. Michalski escreve: "a lembrança mais forte que guardarei do seu desempenho é a das suas cenas de segundo plano, quando, com gestos apenas esboçados

\footnotetext{
37 Jan Majzner Michalski (1932 / 1990) conhecido como Yan Michalski foi um teatrólogo, crítico teatral e ensaísta polonês-brasileiro. O nome "Yan Michalski" foi forjado pela família para dar-lhe fuga em um navio, depois que os pais foram seqüestrados pelo regime nazista. Chegou ao Rio de Janeiro aos doze anos. Em uma de suas primeiras atividades participa do curso de teatro de $\mathrm{O}$ Tablado, iniciando suas primeiras experiências como ator e diretor teatral. É da primeira turma da Fundação Brasileira de Teatro (FBT), formando-se em direção teatral em 1958. Aluno de Adolfo Celi, Gianni Ratto e Ziembińskit.
} 
ou com discretas reações fisionômicas, ela traduz a poética e atormentada alma de Neusa Sueli” (MICHALSKI, 2005.p. 97).

Seguindo na verve desbravadora, Fauzi revela outros novos dramaturgos, dirige peças de Antônio Bivar (Abre a Janela e Deixa Entrar o Ar Puro e o Sol da Manhã, 1968), Zé Vicente de Paula (O Assalto, 1969), e Elóy Araujo (Seu Tipo Inesquecível, 1970). Numa entrevista para a extinta revista O Bondinho, publicada em 1972, o autor Zé Vicente deixa um testemunho sobre o que os dois parceiros pensavam juntos no tempo em que conviveram:

O teatro só tem sentido pra mim se é um ritual (...) Quando eu digo ritual é no sentido que Fauzi Arap, meu mestre inicial, me comunicou. O teatro que sonhávamos juntos nas ruas de São Paulo, de noite, era a semente de um ato mágico. Poderosíssimo. Mais poderoso que a droga. Seríamos oficiantes de uma liturgia sacra. Seríamos mágicos, não atores. Comunicaríamos a um público o invisível. Numa linguagem que se preocupa com o Secreto. Traríamos, como médiuns, as divindades e os espíritos à plateia. Éramos tão ambiciosos que preferimos nos superar por uns tempos. (José Vicente, 2008, p.290)

\section{A ALQUIMIA DO TEATRO}

O dramaturgo fala, na entrevista de 1972, sobre o teatro que os parceiros "sonhavam" no tempo das montagens de Santidade e O Assalto, entre 1968 e 1969. Duas peças potentes, mas ainda não exatamente nesse ideal de teatro como "ato mágico poderoso" operando no "invisível" e no "secreto", com "divindades" em ação. A "ambição" artística da dupla tinha fundamento, ao que parece, numa verve que cada um pôde honrar, de certa forma, em trabalhos diferentes, ambos no ano de 1971. Zé Vicente quebrou a banca do teatro carioca com a peça Hoje é dia de Rock, no Teatro Ipanema, Rio de Janeiro, direção de Rubens Corrêa, montagem comentada no prefácio de Aimar Labaki ao Mare Nostrum: "não era um espetáculo de teatro. Era uma celebração à vida, um ritual de exorcismo, um espasmo de criatividade, vivido por artistas e cidadãos e que esperneavam por um pouco de oxigênio para o palco e a plateia.” (LABAKI apud ARAP, 1998, p.13). Praticamente ao mesmo tempo, Fauzi dava vida ao show Rosa dos Ventos, de Maria Bethânia, uma criação em que ele pôde, ao que parece, de forma contundente e com resultados excepcionais, transformar em arte toda experiência "alquímica" que vinha decantando desde 1963.

No contexto de uma "alquimia do teatro" de ação social (a ser discutida no capítulo "Oficina Alquímica"), considerando relatos sobre o impacto do show no público, talvez Rosa dos Ventos tenha cumprido o papel de somar um equilíbrio mínimo entre as correntes 
psíquicas da multidão, naqueles dias de opressão violenta na Ditadura Militar. Os símbolos alquímicos veiculados no show germinariam na poesia, florescendo como a harmonia possível no Inconsciente Coletivo, lançando a informação na rede das relações. Um dos registros do acontecimento está nas palavras da diva, colhidas no calor do momento, numa entrevista que toca do processo criativo à reação do público, na mesma revista Bondinho, de 1972:

Rosa dos Ventos é o seguinte: “a ideia de Fauzi é fazer eu solta com os quatro
elementos: fogo, terra, ar e água. Então, daí, junto comigo, ele escolheu os textos e
músicas (...) Começa com terra, eu vou falando das minhas coisas, falando da minha
chegada aqui no Rio (...) ligação com religião, a família e tudo, com amigos. (...)
Depois entra o mar, a água, que a gente usou Caetano e Caymmi, só falam em mar,
aqueles negócios. O fogo que é meu lado, sabe, porra louca, minha paixão, aqueles
negócios que eu tenho muito de me apaixonar e morrer, aquelas coisas; e o ar que é,
vamos dizer, a Bethânia do Carcará hoje, entende? (...) Agora, como surgiu esse
negócio dos quatro elementos também eu não sei. (...) Foi uma coisa incrível, a
gente ficou tanto tempo só conversando (...) Negócio de amigo mesmo, de um
encontro de amor, de amizade, de trabalho, resultou num trabalho maravilhoso.
(BONDINHO, 2008, p.294).

Sobre "como surgiu o negócio dos quatro elementos" Fauzi comenta:

A ideia de estruturar o show em quatro partes me veio da leitura de Jung (...) "Psicologia e Alquimia" (...) a informação de que o número QUATRO organiza. A exemplo dos pontos cardeais (...) no processo de recuperação, seus pacientes costumavam sonhar com símbolos que iam se estruturando numa forma mandálica, que quase sempre incluía o número quatro. Também observara que eram quatro as funções principais da existência humana - pensamento, sentimento, sensação e intuição, e que se opunham duas a duas: o sentimento equilibrando o pensamento, e a intuição fazendo par complementar com a sensação. (...) não consegui impedir que uma quinta parte se intrometesse (...) depois vim a descobrir que o número cinco sempre arremata a existência dos outros quatro, e, por significar o centro da mandala formada pelos outros, realiza a inteireza da proposta. (ARAP, 1998, p.153)

Anúncio do show Rosa dos Ventos em página de jornal de Salvador, meados de 1972.

Juntando as descrições dos dois artistas, parece que a ideia, resumindo, era usar um esquema alquímico absolutamente básico, e flexível, para montar o roteiro do show e, a partir daí, no jogo da conversa entre amigos e da troca de estímulos poéticos, no fluxo do "encontro de amor, de amizade, de trabalho" fazer "um trabalho maravilhoso." Por simples que pareça, é um plano perfeito que deu certo. Nesse prisma, a Alquimia proposta por Fauzi teria algo de uma parceria entre a fluidez do Mare Nostrum, na sabedoria das águas que sempre encontram seu caminho, e o engenho que direciona seu fluxo, no caso, a partir de um encontro sensível, da percepção sensível, ou da afetividade entendida como energia pulsional e libidinal, como emoção ligada ao corpo. Claro que fica mais fácil com parcerias como Maria Bethânia e Flávio Império, o diretor de arte, parceiro constante de Fauzi e um dos artistas mais brilhantes de sua geração. As palavras de Bethânia ainda indicam o que parece ser um aprofundamento 


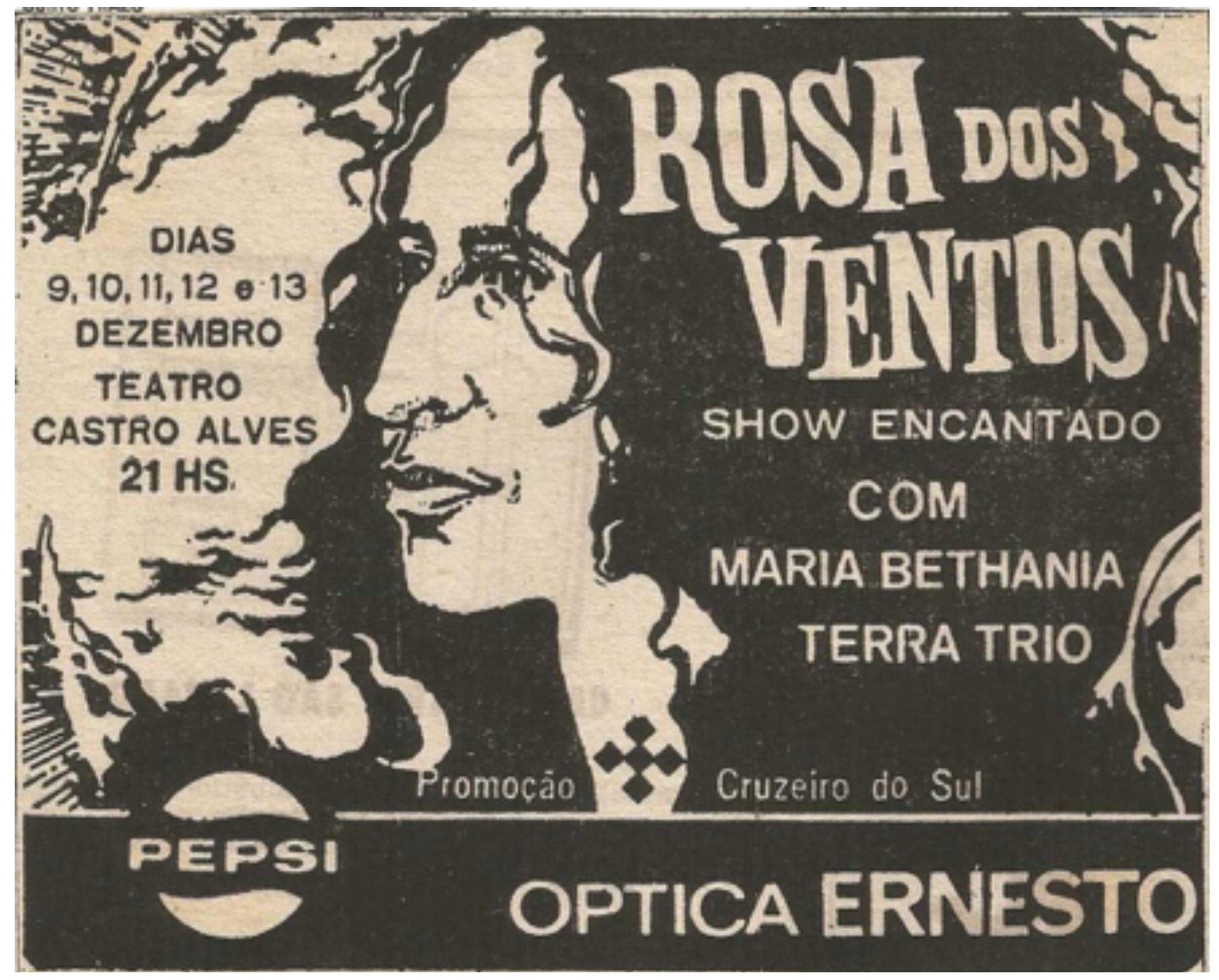

da noção de Fauzi por trás do toque que ele teria dado em Sérgio Mamberti no ensaio de $O$ Inoportuno, sobre "não precisar fazer nenhum esforço para ser o personagem":

(...) eu me amarro em trabalhar com o Fauzi porque ele me dá toda liberdade. Por exemplo, não tem uma marca nesse show, eu não tenho marca nenhuma, não mandou eu decorar texto nenhum, entende? (...) A preocupação dele era exatamente pintar eu como eu sou, mostrar pras pessoas como é que eu tô, o que que eu quero fazer. (...) Sei lá, depende de como é que eu tou mesmo. Se eu tou de mau humor eu faço o espetáculo de mau humor, uso meu mau humor pra trabalhar. Se você não mentir, sabe como é, nada fica errado. Cê pode dizer eu te amo, sentindo eu te odeio: passa "eu te odeio". E o bacana no Rosa do Ventos é que eu tenho a liberdade de parar e responder pra plateia, entendeu? Não tem esse negócio de por que eu tô no palco, a pessoa na plateia, estou no pedestal: nada disso, sabe? (ARAP, 2008, p.295)

A direção do show parece trabalhar na espontaneidade da diva. Usando um jogo de símbolos - no caso, estruturado pela Rosa dos Ventos junto ao quinto elemento invasor - para organizar todo material psíquico presente; primeiro, o dela, no processo de ensaio, depois o do público, potencializando e fertilizando a mesma espontaneidade.

Parece ter havido uma "sincronicidade" entre o conteúdo "alquímico" do show e os anseios de um público sufocado pela situação política e ao mesmo tempo atingido pelos raios 
transformadores e libertários da revolução de costumes em curso. E havia, certamente, o dom artístico de Fauzi, que talvez buscasse, fundamentalmente, catalizar toda essa energia criando condições poéticas para que cada gesto e palavra de Bethânia, não só em direção ao público, mas na direção do coração dela mesma, encontrasse terreno fértil para a poesia, ou para o que fosse aquilo que acontecia naquele show:

\begin{abstract}
Aconteceram coisas muito estranhas, maravilhosas. Ele queria fazer (...) todo o teatro dar esse clima, entende? Esse negócio de catedral, de igreja... (...) ninguém aguentou fazer, eu não aguentei fazer, as pessoas não aguentaram ver, ficou um clima misterioso. Ficou muito forte, as pessoas desbundavam, eu também desbundei, não consegui fazer. Teve um dia... Eu tenho um amigo que é halterofilista (...) pedi pra ele ver o ensaio, daí ele foi. Aí eu comecei a cantar, eu não tava com nada ainda, não tinha nem cenário. Eu tava sentada assim, cantando. Ele teve um ataque, quebrou tudo. Quebrou tudo, sabia? Não tinha nada, era um homem que fala assim: "Ah, você está muito bonita hoje". (...) quebrou tudo, ficou louco, me deu pontapé, foi uma loucura! Aí eu falei: "Fauzi, você tem que mudar, vão me massacrar nesse palco". (...) Se esse cara quebrou tudo, as pessoas iam morrer sentadas, entende? Então (...) ele me deu outras indicações, eu abri mais, suavizou. Mas muito pouco, né? Sei lá, as pessoas ficaram... possuídas, vibravam muito. O show mexe muito com todo mundo (...) as pessoas vêm desprevenidas e de repente tomam uma porrada na cara sem saber por causa de quê. E é uma porrada legal, porque... Esse show tem crises, as pessoas brigavam - na porta, as pessoas pegavam o carro e jogavam no poste, outras desbundavam de felicidade. Tem tudo, todos os lados, né? É uma maravilha, um sonho. (MARIA BETHÂNIA, 2008, p.294)
\end{abstract}

Estes depoimentos se tornam mais relevantes pela dimensão do sucesso de Rosa dos

Ventos. Por outro lado, um sucesso bombástico do qual restam poucos registros, como acontece com boa parte das artes cênicas duplamente efêmera quando desaparecem as marcas de sua existência, perdidas em publicações arquivadas ou submersas no fluxo gigante das informações. Mas o depoimento da diva não deixa por menos:

Teve gente que veio da Bahia aqui no Rio e viu 36 vezes (...) filas reservadas durante uma temporada inteira de mil pessoas (...) No último dia, então, que eu botei todo mundo no palco (...) que maravilha! Superlotou, as pessoas ficaram penduradas, eu com medo das pessoas caírem, e o povo querendo entrar, quebraram a frente do teatro todo. Eu disse: abre, faz de porta aberta. Aí ficou assim de gente. (...) todos os dias e tinha briga na porta porque lotava o teatro. Aí ficavam duas filas, uma normal pra qualquer lugar, e a outra, que era maior do que essa, pra sentar no chão, pagava mais caro no chão do que nas cadeiras! Briga por causa do chão! Eles adoravam, queriam ficar ali, puxavam a minha roupa. (...) Os homens, as mulheres ficam todos... uma maravilha... as bichas, todo mundo. (...) Me agarram. Nessa temporada me deram uma dentada. Eu sentada, depois do show, morta (...) não tava vendo nada, mole. De repente senti aquela dor no peito, Mas o susto que eu levei! Foi uma dentada no meu peito. Ficou marcado, foi uma dor arretada. Tarados, loucos! (...) Teve um dia maravi-lhoso: Clarice Lispector foi ver, segunda vez que ela tinha ido ver. E tinha uma sala enorme lá no Teatro da Praia, (...) ficou que você não andava de gente, né e a Clarice ali em cima, na escada, toda maravilhosa. Aí aquela zoeira de gente, sabe, falando comigo, transando. Ela parou, deu um grito na escada, falou assim: "Esse show não termina nunca". Sabe, um discurso, mas tão maravilhoso, e aí, ficou aquele silêncio, todo mundo parou pra assistir ela, né? Ela séria, assim no alto da escada, todo mundo lá embaixo, e eu morta de nervoso, né? Aí ela falou que coisa lindíssima, ela disse assim: "já vim uma vez (e falando alto), 
hoje é a segunda, e eu sei que vou voltar muitas vezes. Maria Bethânia, esse show não termina nunca, é um show eterno". Tem um texto dela que termina assim, num livro dela: mais ou menos isso, termina dizendo: "Esse livro não termina nunca". (...) Quando ela ia nos ensaios, eu morria de medo dela. O primeiro dia que ela veio o Fauzi perguntou: "Você não gostou do show?" Ela falou: "Faíscas no palco!" Maravilhosa, né? (ARAP, 2008, p.294)

O relato mostra a energia do encontro do teatro com a música e a literatura, a inspiração do momento, e a energia que cerca o show com sua estrutura das quatro direções mais o quinto elemento. Talvez seja interessante lembrar que uma das simbologias do número cinco é justamente a Iniciação, do ser humano que abandona a inocência ao se perceber vivo para além da matéria, então se compromete com o caminho da evolução psíquica. No sentido pessoal, de Fauzi e talvez Bethânia e Flávio Império e outros parceiros, faria sentido como metáfora para um momento de libertação vivido no contexto Contracultura histórica e a revolução de costumes. E no sentido coletivo, ou social, talvez cumprisse a função simbólica de um chamado necessário à transcendência perdida num materialismo violento, um chamado ao Coração, ao espírito da Natureza, ou à poesia da vida, num momento em que o terror de Estado e a propaganda da Guerra Fria oprimem e causam estragos no Inconsciente Coletivo.

\begin{abstract}
Nunca em toda a minha vida trabalhei num clima tão inspirado e encantado (...) os ensaios fluíram de forma estupenda, tudo se harmonizando e encaixando lindamente. (...) A força de mobilização do espetáculo era tamanha, e sacudia tanto o espectador, de forma única, que provocava uma estranha idolatria por Bethânia e por todos nós. (...) impossível não deixar de concluir que todo aquele meu estudo sobre alquimia é que acabara gerando essa forte corrente de inspiração (...) os ensaios, uma energia fantástica costumava nos cercar, algo difícil de comunicar (...) Havia em nossa disposição coletiva um propósito de transformação e alquimia para cada um de nós. Flávio, Bethânia e eu, como muitos dos que nos cercavam, tínhamos naquele momento a disposição de realizar uma transformação radical em nosso estilo de vida, cada um à sua maneira. (ARAP, 1998, p.154).
\end{abstract}

Como o Dioniso arcaico, o chamado Iacco, parceiro de Deméter e Perséfone nos Mistérios de Eleusis - Fauzi também foi consorte das deusas: estreou Clarice Lispector no teatro, revelou a sombra luminosa de Tônia Carrero e lançou Maria Bethânia para o firmamento num sucesso estético superlativo que revela o alcance do trabalho do diretor com sua obra vibrando forte no coração do público. Fauzi está em fase de provocar faíscas e operar maravilhas no palco. De alguma forma, mesmo não sendo estritamente teatro, Rosa dos Ventos cumpre o que Zé Vicente chama de teatro ritual, com sua "semente de atos mágicos poderosíssimos", em que os artistas seriam "oficiantes de uma liturgia sacra”, "mágicos, não atores", comunicando "o invisível" e o "Secreto", trazendo "divindades" para a plateia. Esta última ação, das "divindades" na plateia, pode ser compreendida como uma metáfora, significando a capacidade de ativar forças inconscientes, ou no Inconsciente Coletivo, de vibração elevada e ação efetiva nos corações e mentes do público. Seja como for, certamente 


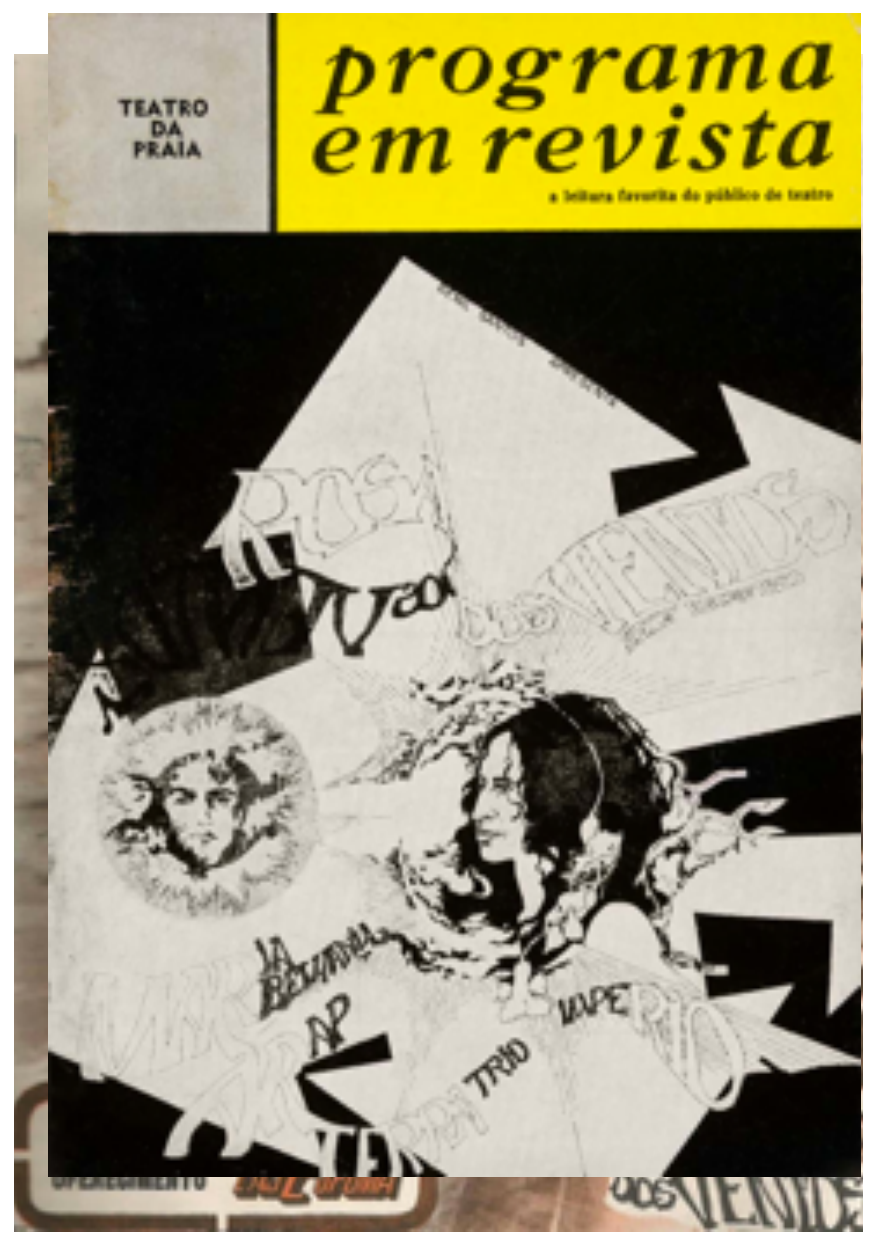

alguma coisa ia bem, Fauzi entrava nos anos 1970 com uma carreira de diretor consolidada, e a batalha parecia ganha. Porém, ainda havia outra morte no caminho do artista. $\mathrm{O}$ depoimento não especifica uma data, mas indica que mais ou menos três ou anos quatro depois de encerrar a terapia com Dr. Murilo, por volta de 1968 ou 69, Fauzi retoma seus "estudos lisérgicos", agora de forma independente. Era outro momento e o uso recreativo do ácido já se popularizava, levou algum tempo antes que Fauzi encontrasse seu próprio modus operandi para que os novos contatos com o LSD fossem efetivamente algum tipo de "estudo":

\begin{abstract}
Embora eu mantivesse um certo distanciamento do que acontecia, tentando ser para os outros uma referência e um equilíbrio, era impossível não ceder à tentação de participar como apenas mais um daquela geração que ia descobrindo e se envolvendo com a questão lisérgica. Com ácidos "pintando" a toda hora, não era difícil receber de presente, até mesmo de um estranho, aquele passaporte para o desconhecido.(ARAP, 1998, p.113)
\end{abstract}

Num outro trecho, comentando seu rápido envolvimento com a passagem do grupo norte americano "Living Theatre ${ }^{38 "}$ pelo Brasil, Fauzi complementa:

Por vezes também tentei entrar no espírito da época e tomei o ácido em grupo, só para descobrir que eu não sabia viajar de forma irresponsável e superficial. (...) Eu enxergava os perigos a que se expunham aqueles que faziam profissão de fé naquelas viagens inconseqüentes, e imaginava as enormes dificuldades que poderiam ocorrer, quando a maré mudasse, e eles tentassem integrar suas descobertas com a vida do comum dos mortais. Talvez uma forma de permanecer fiel, mesmo sem participar dos acontecimentos imediatos, fosse antecipar-me e definir-me pelo estudo

\footnotetext{
38 The Living Theatre - Fundada em 1947 em Nova York, é uma companhia de teatro norte americana, dedicada a um teatro experimental de viés político e performático. Fundado pela atriz e diretora Judith Malina e seu marido poeta, artista plástico, cenógrafo e diretor, Julian Beck, veio ao Brasil no ano de 1971 para colaboração com a companhia Teatro Oficina, depois de um encontro entre as companhias num festival de teatro em Paris, mas a parceria com o Oficina não se efetivou e o Living Theater acabou realizando outros trabalhos, especialmente em Ouro Preto, Minas Gerais, onde o grupo foi preso de forma arbitrária pela polícia política, iniciando um movimento de comoção internacional pela sua libertação, que ocorreu poucos meses depois com sua extradição.
} 
aprofundado de Jung, que talvez me capacitasse a poder ajuda-los, quando fosse necessário. (ARAP, 1998, p.113/122)

O paradoxo libertado no processo terapêutico ainda se impunha. No "subsolo energético do teatro de operações" nem todas as cenas eram luminosas. Como não poderia deixar de ser, considerando o mito, já que Dioniso morre duas vezes.

Se o deus do Teatro pode ser considerado um arquétipo que rege essa arte, é uma força que transita entre os mundos, conhece os caminhos da morte, festeja a vida ao extremo. No mito, Dioniso é salvo da fome dos Titãs quando tem o coração de criança acolhido por Zeus. Que então fecunda Sêmele, mãe do segundo Dioniso, também fulminada por raios divinos quando exige que Zeus mostre toda sua divindade. É mais ou menos esse o momento porque passa Fauzi.

Texto de Fauzi no programa do show Rosa dos Ventos, 1971

\section{AVISD AOS NAGEANIES}

0 teatre morrou?

De repente ninguém mais seve vontade de ver leatro. Mas foi mesmo assim, de repente? E estranhamente, o numere de pessoas coe coeriar lazer teatro cada veg au-entava mais. Os "Protissionais" apavorados. fazer concorrincia umentando de uma forma abeolutamente incrivel. Todos assumiram a morte de teatro fos jornalistas e as pessoas Todos astumiram a mort "bsom Deus e como se a tivessem decretado

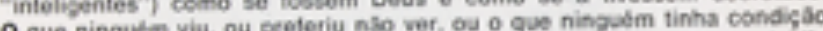

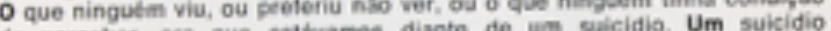
de perceber, era que estlivames diante de um suclolo, Um suic maravihoso. Um suicidio por consumaçilo. Um exemplo de coragem. morrer para renascer. Noeman O. Brown diz: 0 espectader 6 um voyeur". E ainda: "to show is to show the Genita" iO eapectador nas e so um Voyeur do teatro, mas do Cinema. the Teinialo e de uma forma mais geral somos uodos espectadores da da Televiaso e de una foidio vida"t Este fo grande main, o cout" de espirito; Eu me agrido om vocb. eu o munde o um imento acting-out" do escirno, Eu me agndo om voct, eu quevo que moera essa nossa forma morna do nos comunicarmos, assil como na vida prb́priamente dita a violencia ế uma "representaçao inconsciente é claro, como $16 \mathrm{da}$ criacho auténtica. uma "representaçato" da viollncia costra si mesmo. O movimento femininista, o movimenio negre, todos movimentos de rebeldia, retratam fisicantente uma colsa que esta acomtecendo com a cuca do mundo, com a cuca do cada um. 0 que entaciente arança. o pecado b o medo. 0 mbdo de seu lado escuto, do seu lado temining. Os homens escravisaram suas "bnimas", no mundo, suas mulheres. Teatralmente, estupidamente, barbara e primitivamente continuamos a existir para fora. alovera colsa que so curtida dentro pode nos trazer paz. Todos os monstros marinhos. todos os monstros antigos e novos, slo disfarces do medo do colasu porceptiveis a che ny. O munds 4 um imenso "acting-out" do espirito. Poe etoguanto -

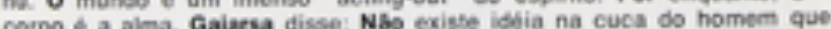
nlo correspenda a um estimulo sensorial. E o ar realiza fisicamente a nlo corresponda a um estimulo sensorial. E o ar realiza fisicamente a idéla de Dous. Ele esta dentro de cada um de nós em toda a parte. E
eu posso passar pouquissimo tempo sem respirar. E eu digo: som 6 vibraçjo. A mesma vibraçlo de que falam todos "Pais de Santo" da vida. A mesma vibraçlo, que na rua, faz com que eu enlouqueca e me ligue na oaral, pressa, a alma dos nossos negocios. como disso Santo Paulinho da viola. Navegar e precivo, viver ndo e preciso? Nilo, viver é

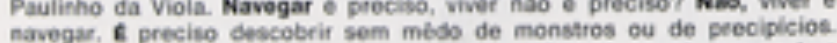
navegar, E preciso descobrir sem mbdo de monstros ou de precipicios
Existem muntos mares e terras por descebeir. NSo adianta chegar na Lus fisicamente. Temos que ser Astronautas de nos mesmos. exishiem muitas Lwas por conhecer:

Tomara morra loge o teatro. Mas morra no lugar certo: fora do palco.

Nada de assassinar "Teatralmense" o teatro. Que cada um acabe com sou drama particular que nasce da dualidade, da divisalo. Guando eu nlio existo integre, inteire, eu me divido e preciso falsamente do outro, preciso do cutro por minha causa, nabo preciso do oulro por amor. Ou mentira; poeque precisar do cutro e sempre por amoe. Mesmo precisar violentamente. 8 o "lego". A vida. "The show must not go on" isso wu li no live do Norman Brown, o me reconheci instanclineamente. Como stoe eu parei em cena vàrias vézes na vida teatro parado sempre e muito. E ha um ano atras, em julho, principio de julho mais exatamente eu parei um espetáculo mea que acontocila no palce do Tealro Maison de France, wiass com grande escandala. Segundo Araripe, fui promovido de uma cabegoria assim, de Ava Geviner, e no mew pacel, acho que tive talvez meu maior momento de gibria. Eu coadjuvei a repeosontacilo do que é a vida carioca. Naquela noile particloamos lodos de um mesmo espeticulo. O palavrlio que ou disse incluia vocés lodos 6 claro, como me incluia a mim tambetm. O palaverto se referia ao espeticulo e um espetaculo nbo exishe sem espectadores no seu papel Mas a futilidade a fofoca o mundanismo tem outros espacos para existir. Eles nbo peecisim do teatro. On se peecisam e que procuram ndile a salvachlo. o teatro é um iemplo. Ev costumava ouvir isso de grandes atores do T. B. C. - achar ridiculo. Mas o foatro tom muito que ver com religibs como gualquer forma de arte. Eu preferi o silencio ha um ano atra porque nilo me foi dada opcho, era uma guerra com tantas paixbes e odios mesguinhos om luta, que eu profori o suicidio a ausèncis. Eu preferi o silencio his um ano atras e eu preberi o silencio ha dois anos, hil trós. his sete anos. quando fui utilizado como bode espiatório da loveura de todos. Essa loucura que lodos agora assumem o transtormam em mods. sem saber bem o que estas fazendo. A imagem de perdido, de confuso, de louco, era a da loucura, confusito de vocès todos. E agora, no ano de milnovecentos e setenta e um eu devolvo a gotm de direito, a vocbs, meus colegas de profisslio que eu amo.

Agradeço a Eneida, que a proposito de Macbess escreveu (Ningutm leu, com certezal: Isso que eurlo twrendo o uma coisa suja. E eu faco, com um ano de atastamento, sem paixlo, a radiogratia da coisa suja: Em andise chama-se projechio, mas no nosso mundo "artistico" podemos chamar mais apropriadamente de teatro. $\mathbf{E}$ assim que o teatro acontece. A radiografia é o teatro acombecendo mais vivo do que nunca a cada segundo do nossas vidas em tódas brigas e conflitos que entrentamos no cotidiano. O teatro, sera com certeza, a ultima ante a morter, eu. profotizo.

Per horror a nós mesmos, nós fabricamos a leucura, as guerras, e tudo - que existe de "mal" no mundo. 0 que eu nlo suporto conhecer em mim, eu "projeto", coloco om vocb o passo o resto da vida brigando comipo mesmo. E teatro. Sb 6 teatro. Porque nso jogar fora as miscaras, e deixarmos de ser canastrōes, os personagens antigos, o drama paleologico, que o toatro sabiamento o profeticamente jis discurtiu. A vida esta atrasada com relaçalo ao teatro. Com relaça ao Qibi. O drama psicologico nibo esta mais no Gibl Vamos abandonar nossas identidados secretas e revelar os super-herbis. Todo mundo 6 super. Alguns se identificaram tanto e por tanto tempo com seus falsos personagons que esqueceram o que existe de super dentro diles. $O$ pior de todos nós e 
a identificaşa com as rospoctivas funçbes; Atônes, diretores. Avares de teatro sotrem muito disse mal, mas nio so éles, os da welovisao e os do cloema, alouns jornglistas, tambim. Os criticos. saso os ove mala facimente (ah, o poder) cedem a temtacilo de formalmente se tacimente fah, on pous (pessoali). E sabo dewses absolutamente

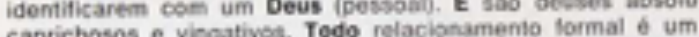
caprichosos e vingativos. Todo relacionamemo tormal do um foema mais relacionamento morto. Precisambs comezar a viver, de uma foema mais fortalece a morte e nos vacina contra a ressurreiçod

Nós somos os "bufores" de lodes hospicios e prisces e guerras do mundo. Se sada um asoumit a sua tlowcura", se cada um conhecer em si sul Se cada um assumiruas a mundo serd luminado por um numetio mula voloncia e suas trovas o mundo sera nos prolestem de nós mesmos. maiser de esweras. Nossas supertecoet nos prosegum de nos mesmos. espltho partido o a imagem de nossa atma partida., nos te-tos modo dis verdade bruta. Takez posskmos nos perdoar do ato agora ter sido ass $m$. talvez tasa parte do procosso. Da criaclio. No processo "alquimico

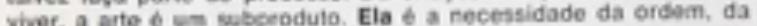

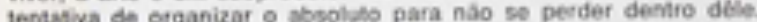
Jose Wiker consaiou "O Aqquileto e o Imperador da Assiria", durante mulass anos. Eu sei. Ele larooy de fazer teatno, fez vestibular, ankilise escrevey pecas, ganhoy um concurso. e voltou. Ele estava criando criando quands aparememonte nao estava. E se encontrou com Rubens e Ivan. E juntos realizaram a incrivel peça do Arrabal. Arrabal fas o ieatro certo no etpace certo na cuca

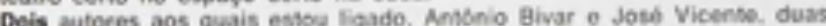

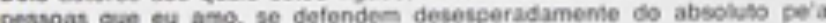
identificas lo formal com a autoria de suas peças, como forma de sobrevivêncla. Sobreviver $b$ a salvaçlo pois parece que viver nilo existe. viver leva a morte, como disse Santa Clarice Lispector. Plinio Marces joga seas fantasmas em cena e as pessoas chamam de "realismo", Nao, ndo o. Os fortasmas slo vivos. Nossos fantasmas estáo todos "leatralmente" vivos: salo os quo Plinio coloca es cena, entre outros. Mas ele "revela" os mais significativos. Os nossos fantasmas so escendem atrás dos palarbes. E a famliaridade com os palaveoes distanciadot do sua origom, nlo nos deixs perceber, 0 homossenual (a bicha louca) ef o fantasma-argubtipo-vivo que mais nos apwora

Descurtimos todos (os que conseguem) e cotsmos pelo papel confortavel de machses - estou falando de Navalha na Came, é clare. E a

Prostituta-Mbe de Familia o o re, fato-radiografia perfeito do que o homem faz com a mulher.

- Pasquim e um adiamento; a bicha do Pasquim, evando deixar ce existir andnima, para "incorpecar" nos seus criadores fara do Pasquim - jornal do futuno. O Pasquim. es incrivel e atual ponque é um retraso, o adtamento 4 geral. $O$ humge tambetm e uma forma de sobrevivincia. 0 Pasquim repousa sobre as ond:s. Hay que remar, que las hay, las brujas. E Paulo Francis se trancou numa torre de palavras e pensa que esta a salvo (SiC) numa bere de palarras com uma caixa de uisque. Alías o uisque é a maior bandeira nacionai do mido que a bicha incorpora.

Mas o que Pavio faz e esperar sesesperado que verha um cavalheiro andante que liberie sua "Inima" de longos cabelos dourados (nalo

precisa se pereceupar, Paulo porque Jung diz que ánima. a alma of homem of fcminins entso voce continua protegido pelas palavras da rarlog). Satyrican \& um dos filmes mais geniais que it vi. Quando Nie reduz tudo aquilo a um problema de Fellini virar a milo ou nilo, the est passande e malot atestado de burricen, de cegueira que if vi Mas Ne massace um clogio $E$ preciso mu'to malabarismo para fabricar com a intelighncia essa burrice. Sorey perideria, mas intolerancia nilo se forma com palavras diticeis. Ela bi simples.

Os super herbis escravos de was androginia sto vitimas de piadinhas sobere cus virlidade. Caetano quando cantou t Proibido Proibir for oracionado com a palascinha tabu. Agora viros um Deus. E E. A androginia de Caciano o Bethinia e uma forma de revelaçlo. Trats-se da coniuncla de conteluios, trats-se de encontrar Buds dentro de si

trata-se de ser Deus Vemos acabar com o testro. Acabar com o teatro E acabar com es preconceitos. Alo, alo, ebtas de quatro? Quem que acabar com o teakio? 5alve velho guerteire que assumiu sua loucura. Savio Abelardo, mey maior respello por sev trabsiho, profeta A minha androgina eu ocithei muato tempo atras de minha loucura. Por medo. Um amigo me disse que com o cabelo comprido assim eu parecia ve manstro de mim mesmo

Galarsa disso: palavia sem a mbika certa e letha que mata o que eu deside sempre procuro no teatro 6 a mosica. Como alor semgere fui "intuitivo", o que quer direr, ligade a música subserranes da palave Me lembre de Vincius duendo tom acredita na musica ds palwe assim cemo ey axresta fa palma da minica

fivie Rangel nos seus melhores momentos sempre foi um grande maestro. Eu me tornei o muestre da sutileza, o btims diretor de ator. $t$ preciso muso peito pars entrentar essa parads porque enfrents o evero significs se entrentar, Sempre que se talava nisso, se superis gue ey nlo era exalamente um diretor. fos um ator que passava a dirigir, e que tinha muina habilidade em dirigir outros atbres porove era excelente. etr Depeis que eu comecei a dirigir, eu me transformei num ator geniak cy me trandormaram, ate es que me pichavam quando eu era simplesmerts ator. Mas eu sou ator e sei: Nao existe outra forma de dirigir. Pedemos construir espethculos 6cos, ou com auxilio das circunsthncias um bom espetsculo mas o alor o fundarnental Ey sou um diretor. Dite isso. se espots o assunto. Tedos temos como tarefa de vida tornar-nos um. Chaplin: diretor atoe de nós mesmos. Eu ealou com varias etapas cumpridas. O teatro o o meu laboratorio. Falei? Que mania de atrasarem a vida da gentel

Música nilo se faz sem publico. Música ô teatral. Existem notas nilo captadas pelo ouvido huming. labo 6 "cientitico", e slo as "vibracles" o som. Eu nso entendo de "Harmonia" mas eu adivinho que poder-sela aprender muito sobre a vida estudande-se música? 0 mundo é uma escola onde a gente precisa sprender a cilncia de viver pra nilo sotrer. Eu amo, entilo ou aprendo. $\mathbf{E}$ dificil eata linguagem. mas a assim, eu isso com todo o meu amor. Eu amo o espirito de Tile. Eu me amo nele. Lí em cima do pisno tem um copo de veneno, quem bebeu. morre. Eu amo Rogdrio Duart:

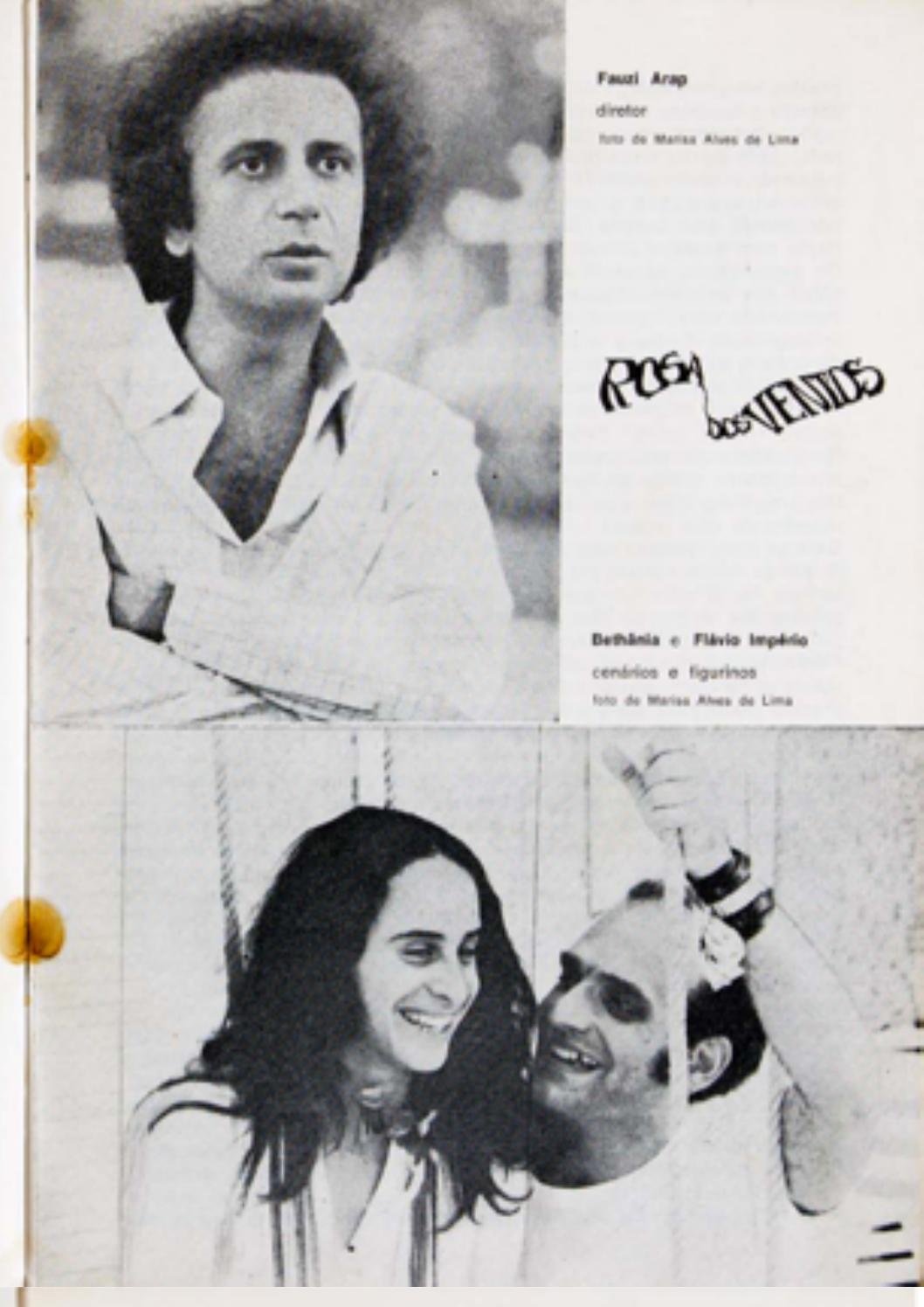

cuem eriticamente nunca falei, e lem no espetaculo valias músicas com letra sua, ev amo Tite, minhs paixio mais recente, eu amo The ceima de todas mesquinharias e bicharias de voces todos e eu digo. Elis fascinada pela forma corre o risco da slienacilo no espirito cabstrato o sem abstrato. Mas ela esta se quelmando da sua maneira. à parfoicho Sca, que cla a qualquer momento preencherá com sua alma conorme Quando dis: Eu quaro cantar como um instrumento: $\mathbf{E}$ facil perceber o absurdo, com um certo atastamento: eu guero sar um instrumento abstrato acima de tbda critica, tu quero set a perfeiclo! Mas isso nlo é mais gente, isso e ser uma peça de miquina, nio existe nada mais bonito que um ensaio, nalo existe nada maís benito que o êreo. nós estamos por fora da criaclio; Deus e muito generoso nos seus irros. elle nos inclui a todos ele nso marginaliza ningulm e nilo tem nerhuma eaptcie de preconcaito. the 6 o anth-1catho. Nosso drams nerhuma eriado por nos nasce da separaça Adlio e Eva expulsos do pumaino

BETHAFIA 4 o drama vivo. Faz parte dela generosamente sus vida que cla reparte com e publico e vive numa especie de clausura nossa sacerdotiza ndo sei bem de que. $\mathbf{\epsilon}$ a mais amadora-amante das cantoras. Tla ama Bullie Holliday, ela ama a pestoa que nlo se trai, que nio se wiana na funcle doe ererce. colsa que nds todos faremos.

Ainda flis: eu tenho uma divids com ela que ela ignosa na época do ino da bossa, eu estawa muito perdiso, o sem nenhum "gas", cu niso conseguia representar direno. Ou meihor eu nio conseguia represemar fu estresi sotalmente afonice. uma peca na epoca. Era a recusa

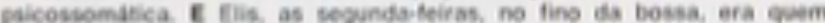

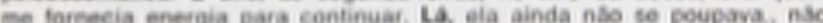
Gha ainda se profissionalizado. Como uma orande médium enchia o leatro de som, de energia radiante. Nio havia

senhuma economia. Eu, conscientemense niso via semtido nenhum en ucresentar, (eu nlo via semido nenhum em viveo). Mas quando eu ví. Elis cantando. sensorialmente, eu percebia alguma coisa. MSo fazia santido by me sentir melhor por causa de uma cantora. eu tirha bilhóes de problumas pra resolver mas era assim onde esta sua alma. Flis? Balanca de novo os braces rege, faz tudo, voce 6 um maestro, voct niso t uma cantora, voct e muito mals que uma voz

Fermanda Monteneoro. Marilia Péra, Marlene, Tónia Carrero, muita gente cem seus momentos de santidade.

Boal fol meu grande mestre de teatro, no finzinho da fase burea do Arena X Xrvier, Vianinha. Flavio Migliaccio, estaram todos ainda li. Boal be ensinou a surleza. He e um grande maestro dela. Ele recuou com medo de se conhecer. Ah. "machonismo" do teatro de Arena... Eu is anto Augusto.

Uma noite eu encontrei um anjo que me tevelou uma coisa; que o erpeticulo que fiz. Pento do Coraça So selvagem, eta religioso. 0 anjo chamase oto Lara Pezende. Eu nilo o conhecla. Ele me disse - be a primeira ves que ey entrei num teatro e me semeil numa igreja.

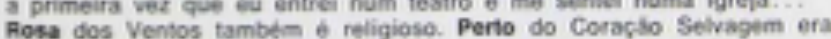
Rosa dos Ventos tamberm Ce religioso. Perto do Coracso Selvagum divina Rocha, Dirce chaplin Migliaccio e Jose arquitelo Wiker. E Carlos 

técnicas arcaicas do êxtase, através das quais um xamã, em estado extático, é tocado pela morte e com isso adquire o poder da cura. No livro "O Teatro e seu Duplo", o artista e pensador do teatro Antonin Artaud resgata para a modernidade a ideia de teatro como uma atividade mágica real, relacionando o teatro ao ritual como prática de cura, ou purificação, no sentido de abolir a cisão entre corpo e alma. Certamente, Artaud e Grotowski foram lidos e seu pensamento assimilado por vários artistas da geração de Fauzi, em sua necessidade de realizar uma forma de arte que praticamente pedia para acontecer. No Brasil da Contracultura Histórica, essa tendência renasce com as cores locais, como revelam os depoimentos de dois ex-parceiros de Fauzi que foram fundo na tendência, Sérgio Mamberti e Zé Celso Martinez Corrêa. Ssendo que este último se firmou e se aprofundou na tendência ao longo das décadas, criando talvez um novo gênero de teatro, chamado por ele de Tragicomediaorgia. A relação do que veio a se tornar o teatro de Zé Celso e do Grupo Oficina com o pensamento de Fauzi é analisado no capítulo Oficina Alquímica. Naqueles dias de contracultura a tendência ainda se manifestava de forma totalmente experimental, e ainda totalmente ligada à experiência lisérgica, ligação que encontra eco na trajetória de Artaud e seu pensamento fortemente influenciado pelas experiências vividas numa viagem ao México, em 1936, com o objetivo de pesquisar o ritual do peiote entre os índios Tarahumaras. Sentindo na própria pele de "homem do teatro" a experiência xamânica e escrevendo sobre isso dentro do léxico ocidental, o pesquisador resgata para o pensamento do teatro moderno o elo essencial desta arte com esta sua origem ancestral. Na verdade, para além de sua ligação com as substâncias usadas para acesso a estados extra-ordinários de consciência, que não seria necessariamente brigatória, como prova a arte de Grotowski, que não tem registro de relação com qualquer substância. Mas naquele momento, foi o processo, talvez com alguma influência de Fauzi, por seu pioneirismo na prática e por seu protagonismo como artista, admirado e respeitado, e ainda por sua parceria e amizade com os artistas citados.

Na época, para além da peça "Hoje é dia de Rock", de Zé Vicente, e do show Rosa dos Ventos, essa urgência - ou essa tendência estética que favorecia o surgimento de um "teatro ritual" encontrou ainda outras manifestações. Duas delas foram produções que envolveram amigos próximos de Fauzi, a mais notória é a montagem Gracias Señor, do Teatro Oficina, comentada na sequência em depoimento do próprio diretor. Outra menos conhecida foi a existência relâmpago de um grupo de teatro que parece ter tido presença marcante durante ao 
menos uma temporada bastante especial, mas por pouco não desaparece da história, tão raros o registros encontrados, apesar das grandes presenças envolvidas: entre outros e outras, Sérgio Mamberti, Claudio Mamberti, Julio Callado, Clóvis Bueno, Zé Vicente e Ricardo Petraglia (na guitarra). Ao que parece, era um grupo de teatro com atitude e nome de banda de rock, os "Tigres da Noite".

Sérgio Mamberti - Eu vou te contar o que aconteceu comigo. Eu estava no Rio de Janeiro, nós fizemos uma peça chamada "A Última Peça", que é a peça posterior ao "Hoje é dia de Rock", do Zé Vicente, que ele escreveu pra nós. Então, um grupo de pessoas que tinham estado muito junto em Londres e tal, Clóvis Bueno, eu, Claudio, a Gi, minha mulher, Semme Lutfi... (...) naquela época a gente falava: "O teatro está morto!" E o o Zé então fala assim: "o teatro está morto, então: "A última peça."

Sérgio Mamberti, Zé Vicente e Fauzi Arap eram amigos, deviam compartilhar percepções similares e algumas das mesmas angústias. Com certeza, esta em particular, sobre a morte do Teatro, também atingiu Fauzi, a julgar pelo texto no programa do show Rosa dos Ventos, onde ele também questiona o "decreto de óbito" do teatro, apontado por Zé Vicente. Fauzi atribui o engano desse decreto aos "jornalistas e as pessoas "inteligentes”, ou à crítica e aos sempre ilesos “formadores de opinião". Já então atento ao Mare Nostrum geral, no título do texto, o diretor anuncia: Aviso aos Navegantes. E o subtítulo pergunta:

\begin{abstract}
"O teatro morreu?
De repente ninguém mais teve vontade de ver teatro. Mas foi mesmo assim, de repente? E estranhamente, o número de pessoas que queriam fazer teatro cada vez aumentava mais. Os "Profissionais" apavorados, e a concorrência aumentando de uma forma absolutamente incrível. Todos assumiram a morte do teatro (os jornalistas e as pessoas "inteligentes") como se fossem Deus e como se a tivessem decretado. O que ninguém viu, ou preferiu não ver, ou o que ninguém tinha condição de perceber, era que estávamos diante de um suicídio. Um suicídio maravihoso. Um suicídio por amor. Talvez "Roda Viva" tenha sido a consumação. Um exemplo de coragem, morrer para renascer. (...) $\mathrm{O}$ espectador não é só um voyeur do teatro, mas do cinema, da televisão e de uma forma mais geral somos todos espectadores da vida": este é o grande mal). O teatro de agressão era uma forma de suicídio. O mundo é um imenso acting-out do espírito. Eu me agrido em você. Eu quero que morra essa nossa forma morna de nos comunicarmos, assim como na vida"
\end{abstract}

Mais adiante, nas últimas linhas do texto, Fauzi comenta o poder mobilizador da música popular naqueles dias, do Rock à MPB, e sua influência sobre outras formas de arte, com artistas de outras áreas incorporando procedimentos e atitudes, assim como sua aproximação com o teatro, especialmente ativa nessa vertente "ritual" que se delineava: 
Nós fizemos um show encantado. O ser Maria Bethânia compreendido através dos quatro elementos: terra, água, fogo e ar. O espetáculo tem cinco segmentos. Os quatro primeiros (...) e um quinto que é o Edifício. Ou: o eu-dificio. Ou: o eu-difícil. A presença dos elementos estão mais nas entrelinhas do espetáculo (...) Este é um show de teatro. É teatro. Millor Fernandes disse uma vez que abriu a cortina e aconteceu no palco, para ele, é teatro. Eu repito. Maciel chamou de teatro um show da Gal, me parece, o penúltimo. A importância da vibração do som, a atenção a esta ponte fundamental da comunicação está muito evidentemente escolhida e oficializada para essa década. Talvez porque seja a mais espiritual das artes, blá blá blá blá (ARAP, 1971)

O artista define a Música como a mais espiritual das artes, mas deixa para o teatro, coerentemente com sua origem xamânica, a tarefa da "morte e renascimento" tão necessária quanto simbólica. E mais, na sua visão, essa morte e renascimento poderia ser marcada pela montagem de Roda Viva, de Chico Buarque, com direção do ex parceiro Zé Celso, que, três anos antes rasgava drasticamente a normalidade teatral brasileira, e 50 anos depois seria remontada no fatídico verão de 2018 para 2019 - talvez cosmopoliticamente, diria o diretor. Uma peça kamikazi que explodia as bases dos "edifícios" a serem re-construídos à partir de novas percepções da realidade.

Chama atenção no texto a frase que denuncia "o grande mal" no fato de sermos "todos espectadores da vida", que parece sugerir uma espécie de ideal oposto, o de sermos todos agentes dessa mesma vida / cena, autores, diretores ou atores, no mínimo, protagonistas de nossa própria vida. 40 anos depois, em seu depoimento, Fauzi confirma:

\begin{abstract}
"Vivemos uma espécie de psicodrama cósmico, no qual todas as partes se encaixam magicamente, num magnífico jogo tão rico quanto a arte. (...) Podemos não perceber o quanto vamos criando aquilo que nos acontece, (...) As respostas que fui colhendo ao longo do ano de 71 foram resultado de uma revolução interior longamente desejada. Se eu não sabia o nome do que buscava, sabia muito bem $\mathrm{O}$ QUE buscava. Eu desejava uma transformação interior, radical, e que integrasse em meu cotidiano as percepções mais esplendorosas que eu já tivera em minha vida. (ARAP, 1998, p.170)
\end{abstract}

Fauzi parece sugerir que a morte e o renascimento, no caso, não seria só do teatro. Expressa a consciência do poder dessa arte como revelação de movimentos profundos do inconsciente coletivo, e entende que sua atividade consuma, no "terreiro de Dioniso", mais do que a morte do teatro, a morte de uma realidade objetiva e subjetiva na qual nem ele nem seus pares acreditam mais:

Sérgio Mamberti - (...) E essa peça, a produção tinha uma verba pra ácido e pra fumo. Quem era produtor? Eu, meu irmão, o Julio Callado... Nosso grupo tinha um espaço e passou a se chamar "Os Tigres da Noite". Nós estreamos no Teatro Vereda. O Clóvis Bueno (...) dirige essa peça. E foi o seguinte, no último espetáculo que a 
gente fez em São Paulo, a Rita Lee foi com os Mutantes e falou: 'Pô, que loucura!' Porque a gente fez viajando de ácido. E o espetáculo era uma coisa enlouquecida, linda, muito bonita, muito lisérgica mesmo. (...) Aí, nós fomos pro Rio de Janeiro... primeiro fomos pra Paraty. (...) Essa peça do Zé Vicente era um grupo de atores que estava vindo de uma cidade do litoral, que era Paraty, e na estrada eles encontram um extra-terrestre, que dá Ayahuasca pra eles. Entendeu? Isso é a peça. Mas era um roteiro poético, eu entrava cantando um rock: 'Pra mim ele veio do Peru, de uma tribo no deserto de Atacama!' O Ricardo Petraglia era o guitarrista, era uma loucura. E a gente ia fazer no Rio, no Teatro Opinião. De repente, todo elenco foi pra Paraty. Estava todo mundo lá. Aí, no dia 31, a gente chega lá (...) no bar do Abel, um lugar ponto de encontro, era uma rua que tinha todo mundo, todos os hippies do Brasil estavam em Paraty. Todo mundo queimando fumo e esse negócio todo. (...) nisso, o Clóvis começa a tocar violão e começamos a entrar no texto d' $A$ Última Peça. Nós fizemos $A$ Última Peça inteira nas ruas de Paraty, e fomos andando, e as pessoas foram andando, e nós fomos para a Prainha... (...) A gente fez a última parte da peça ali, e de repente, deu meia noite, aí os fogos e aquelas coisas e tudo, todo mundo tirou a roupa e entrou no mar. E, na volta, pintou uma suruba coletiva. Uma loucura, uma coisa impressionante. Eu me lembro que depois da gente subir assim, tem um cemitério, né? As pessoas trepando no cemitério. Uma coisa louca. No dia seguinte, de manhã, caminhões na porta da cidade, e tudo que era cabeludo, a polícia botando pra fora da cidade. Entendeu? Aí nós fomos pro Rio. Chegamos no Rio: as Dunas da Gal. Pow! (...) Eu lembro que nas Dunas da Gal eu encontrei o Ivan Albuquerque e o Rubens Corrêa, eles foram muito próximos do Fauzi... E aí ele falou: 'Você pirou, né? Você sabe que você pirou, né, Serginho? Não, porque é importante a gente saber que pirou. Porque nós piramos também.' (...) E a gente estava no apartamento de uma menina na Lagoa que era um ambiente de tapetes e almofadas e era uma trepação geral. Muito ácido, muito fumo e não sei mais o quê. Aí, nas Dunas da Gal, essa menina, e mais uma outra menina, que era uma outra tigresinha que tinha uns 15 ou 16 anos - essa menina suicidou-se depois - elas tiram a parte de cima do biquini e vão tomar banho de mar. Aí, eu lembro que o Caetano estava junto com a gente, ele falou: "Nossa, que maravilha!" O Caetano estava acabando de chegar de volta no Brasil [de volta do exílio em Londres]. (...) Aí, de repente, estávamos lá de tarde e o pessoal do teatro falou assim: 'Escuta, vocês não vão vir ensaiar? A casa está lotada.' E a gente não tinha aparelhagem de som. Eu falei: "Então temos que comprar ácido pra fazer o espetáculo!' A Zezé foi batalhar o ácido, e trouxe ácidos micro, que a gente não sabia que o era mais forte, botamos tudo num chá e bebemos. (...) E aí foi assim: Operação Descolar Aparelhagem de Som... Ah, o Tim Maia esta fazendo espetáculo antes da gente. Nós vamos fazer à meia noite, às 9 horas é o Tim Maia. O pessoal foi lá, levaram um ácido, enfiaram na boca do Tim Maia, e o Tim Maia simplesmente abre as portas e a gente resolve fazer. Eu me lembro eu indo pra o teatro, aí bateu a viagem. Aquela: "BVUVVVVV..." Eu falei: 'Caralho! Como é que eu vou fazer espetáculo?' Chegamos lá, a plateia era assim: Glauber Rocha, Jabor, Nelson Mota, o Rio de Janeiro inteiro, porque o Zé Vicente tinha feito um puta sucesso com "Hoje é dia de Rock", e era o auge das Dunas da Gal. Aí nós descolamos a aparelhagem de som, e aí começou. Odete Lara, me lembro que estava na primeira fila. (....) o povo invadiu a arena, porque venderam ingressos a mais, $\mathrm{e}$ não tinha mais espaço cênico pra gente. Ficou uma coisa... (...) E fiz a primeira música, cantei o rock, esse do Peru. De repente eu comecei a olhar as pessoas... Pá! ... Não vou falar mais. Eu fiquei mudo. De repente, eu ouvia assim: 'Eu não tenho nada que falar. Tudo que eu falar aqui é mentira.' E aí foi. Eu levei às últimas consequências aquela coisa de que não dá pra fingir, você tem que ser aquilo que você é. Não dá mais pra ficar fazendo de conta que se é outra pessoa. Então eu não tenho nada a dizer. Parei. A gente estava sem o baterista. $\mathrm{O}$ nosso contrarregra era um menino que tinha sido trazido pelo Zé Celso quando ele fez Plata Palomar, chamava-se Porrinha, era desse tamaninho, ele simplesmente falou assim: 'Eu faço a bateria, eu sei, eu sou bom, pode deixar.' (...) de repente eu olho pro Porrinha, ele larga as baquetas e sai no meio do espetáculo. A Odete Lara olhou pra mim e falou assim: 'Nosssa! Mas que loucura que está isso, Sérgio.' Porque tinha muita gente viajando no espetáculo, e fora também, na plateia. (...) Durou 5 horas esse espetáculo. 5 horas de loucuras. Eu me lembro que num determinado momento eu vejo o Ian Michalski, que era o maior crítico de teatro, tipo Sábato Magaldi e Décio de Almeida Prado, passando por cima das pessoas, assim. Eu falei: 'Caralho! Acabou minha carreira profissional!' E eu olhando. Eu tinha combinado com um americano 
que a gente conheceu nas Dunas (...) ele fazia uns espetáculos com bonecos. Aí ele falou assim: Eu quero fazer uma performance na peça de vocês. Pode?' Eu falei: 'Claro, em tal momento.' Dei um momento pra ele. Chegou aquele momento da peça (...) De repente, ele fala assim: 'Gente, eu tenho aqui no meu bolsa uma cobra se nós fizermos vibrações, todos, eu vou tirar a cobra e ela vai ficar, vai ser tranquilo.' Aí todo mundo começou: 'Oohmm'! O Ricardo Petraglia puxou no microfone: 'Ohmmm' De repente ele tira de dentro da bolsa e não era cobra nenhuma, é um pedaço de pano. Ele estava de costas para mim eu não via o que era. E aí, ele começa a mostrar e foi ficando um silêncio no público, um silêncio, um silêncio... Aí, quando ele vira pra mim, bordado com pedacinhos de pano em retalhos estava escrito: "Teatro". Pow, cara! (...) Aí, no meio dessa loucura toda aparece a polícia: 'O que é isso? Tem que parar essa loucura! O senhor é o produtor?' Eu ia falar, de repente um cara falou assim: 'Não, ele não é produtor. Ele veio comigo.' E me puxou. Era o Gerald Thomas, que era um garotinho nessa época. E aí nós fomos pra casa do José Vicente e vimos o nascer do Sol, lá de cima do Morro do Vidigal. (...) depois eu vejo o filme do Ingmar Bergman, Persona, é uma atriz que de repente ela para. Ela não consegue mais falar. Entendeu? Eu falei: 'A gente precedeu Bergman nisso!'

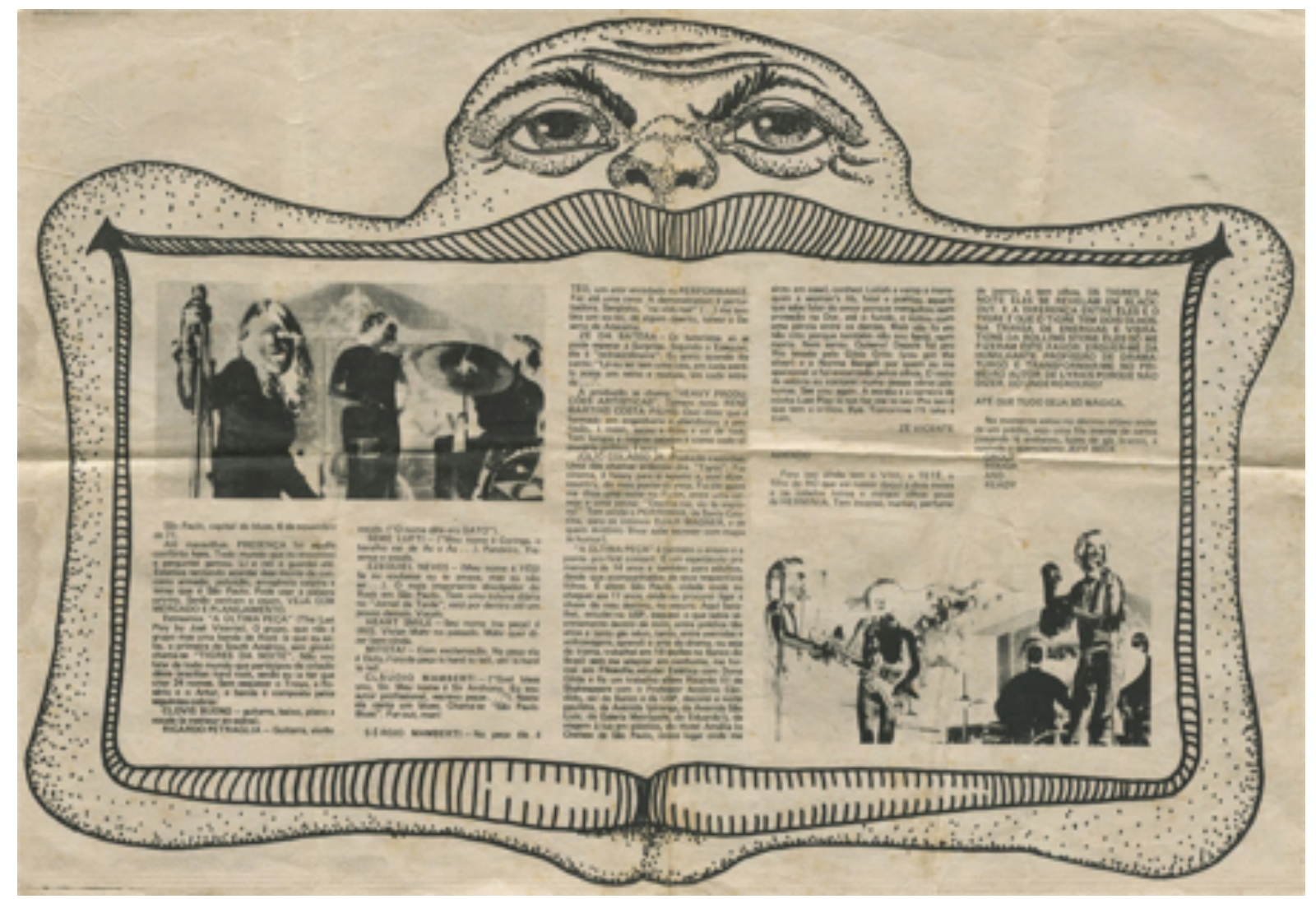

Foldes do espetáculo "A última Peça”, 1971

Fauzi não era o único que lidava com a questão da impossibilidade da fala. A incomunicabilidade, a questão que está no cerne de sua verve criativa é experimentada de formas diversas por parceiros de ofício, e ganha foça em seu universo poético. Uma de suas personagens mais marcantes nesse contexto é justamente um ator que para de falar, uma personagem declaradamente inspirada no caso do ator Samuel Costa Junior, o Samuca, grande corifeu na montagem das peças Roda Viva e de Galileu Galilei do Teatro Oficina, ambas 
apresentadas em 1968, quando, pelo que se conta, o ator encarnava o espírito do ano que nunca acabou. Em várias frentes, o "silêncio" se impunha. Por um lado, na situação política, as vozes dissonantes eram silenciadas pela violência do Estado; por outro, havia a emergência de um pensamento sobre teatro que reclamava o poder da cena sobre o poder da palavra:

Um debate comum, no final da década de 60, início dos 70, era sobre a importância da palavra no palco. Alguns atribuíam a proposta de valorização do corpo à rígida censura política exercida contra os meios de expressão, mas tratava-se na verdade de um fenômeno mundial, paralelo à eclosão do movimento hippie: o corpo reclamava seu espaço, e o sucesso da peça Hair parecia confirmar a universalidade da questão. E foi dentro desse contexto que ouvi falar da estranha piração de Samuca. (ARAP, 1998, p.203)

A invasão do Mythos nesse estudo avança pelo reino de Logos ainda pelas palavras

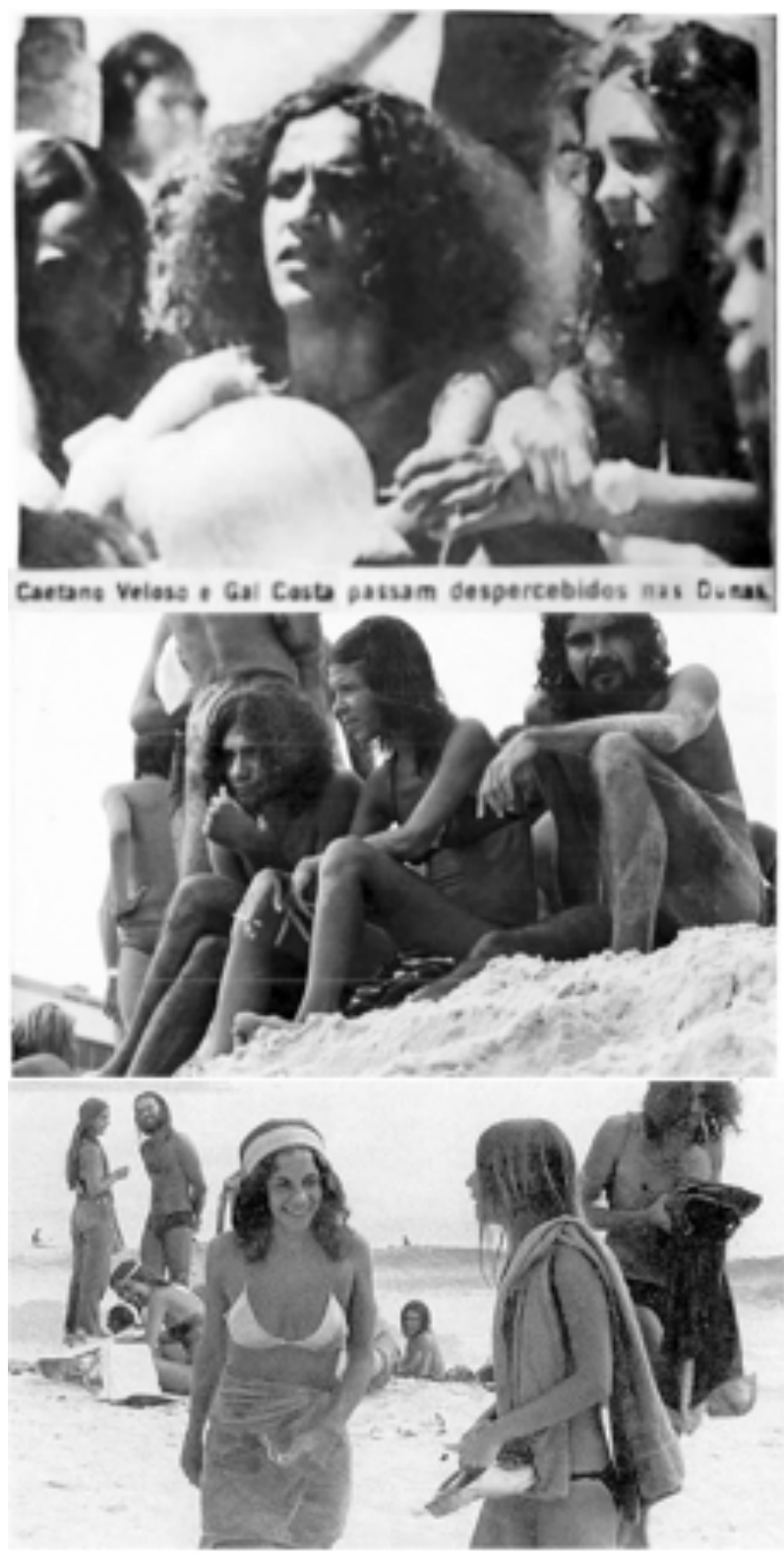

Frequentadores das "Dunas da Gar": Cactano, Gal, Wally Salomào

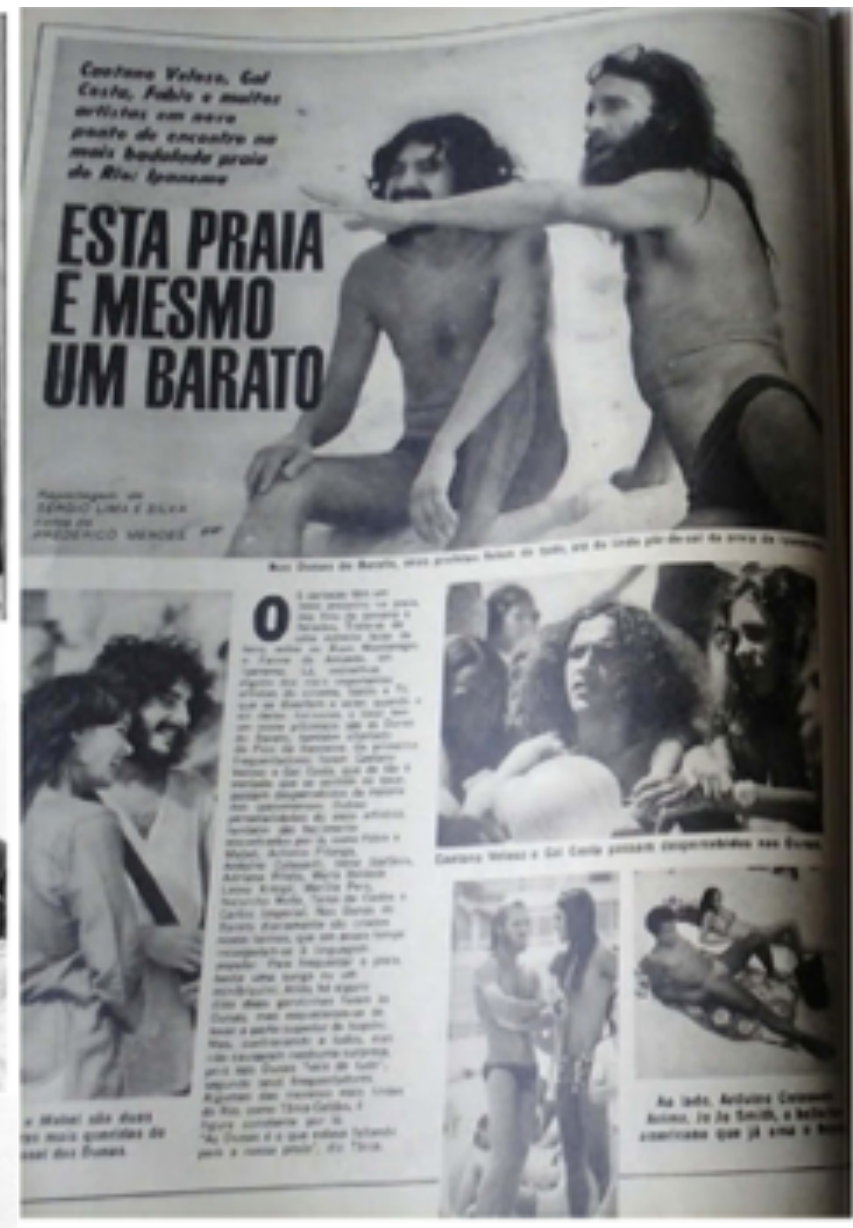

672 Kevisia Amiga Rie de Janeire - 23 de abrit de $1972 \cdot \mathrm{n}^{*} 101$

vivas de outro personagem importante nessa história. No dia 22 de maio de 2017, o diretor Zé Celso Martinez Corrêa dá seu depoimento sobre as circunstâncias da 
gênese de seu "teatro ritual", sobre uma experiência plena desta expressão nas primeiras apresentações "oficiais" do Te-Ato realizadas na universidade de Brasília, em 1971, e ainda a repressão violenta ao Oficina e o entusiasmo na descrição do coro histórico das montagens originais de Roda Viva e Galileu Galilei:

\begin{abstract}
Era um coro maravilhoso. As pessoas absolutamente empoderadas. Foi no ano de 68 , era uma coisa que existia mesmo, antes de começar o espetáculo, eles fodiam, já entravam doidos, entravam possuídos, tinha essa coisa da possessão também, que já antecedia. Aí veio aquela repressão violenta, aqueles ataques... A gente estreou Galileu no dia do AI5, com o coro do Roda Viva sem poder se dirigir ao público, só algumas vezes se dirigiam, não podia olhar pro público, era proibido. Botamos uma grade no espetáculo, isso impactava. E a cena da ida do Galileu, no momento da peça que as ideias dele chegam no povo, tem um carnaval na rua, e a Inquisição entra em cena. Aí, nós partimos pro Trabalho Novo. E desenvolemos o Te-Ato. Que tem a ver com a vida. O teatro é representação pura, já no Te Ato se representa, mas além de representar, tem uma ligação cosmopolítica, uma ligação com o inconsciente, muito mais importante que a representação. A gente procura trabalhar nesse sentido. Para o que se vive no instante.
\end{abstract}

A conhecida ligação do diretor com o pensamento Antropofágico indígena devorado por Oswald de Andrade confirma a palavra "cosmopolítica” em sua fala com acepção indígena. A “Cosmopolítica Indígena” é um conceito nascido do pensamento ameríndio, amazônico e andino, que merece atenção num momento de crise da civilização ocidental moderna. Sua formulação na sintaxe ocidental é ainda rara e talvez complexa, dada a imensa diferença de perspectivas e a própria natureza do pensamento indígena. Basicamente, segundo o antropólogo e professor Dr. Salvador Andrés Schavelzon, da UNIFESP, a Cosmopolítica problematiza a relação da atual sociedade com a natureza, questiona o trabalho, questiona a razão, e propõe caminhos que incluem a Natureza como sujeito. Não como objeto ou recurso para uso humano, mas como como algo vivo e participante da vida social. A mesma relação entre sociedade e natureza que funda a ciência moderna e a sociedade atual, na Cosmopolítica se estrutura a partir de uma percepção de mundo oposta a da economia, da produção e do desenvolvimento, livre do padrão patriarcal de separação que representa a tentativa de controle e domínio da natureza. Ao contrário, não separa, mas inclui todos os seres, não só humanos. Propõe o funcionamento da vida pela participação do ser humano na natureza definida pela interconexão entre todas as partes. A partir do reconhecimento dessa interconexão interage com os não humanos, que também fazem parte da comunidade. Não só as plantas e os animais, mas também os rios, as montanhas e os lagoas. É a política dos homens, das instituições, mas também a da natureza. Respeita e inclui os habitantes dos três 
reinos naturais, e ainda um quarto, intangível, já que reconhece a autonomia existencial e ativa de todos os seres, inclusive os abstratos. Por isso a Cosmopolítica contempla a "ligação com o inconsciente" de que fala o diretor, reconhecendo o Inconsciente como parte da natureza. Uma

força da natureza que tem no Teatro uma interface, a única arte capaz de traduzir suas

flutuações em carne e osso vivas no tempo e espaço, com a liberdade de quem se dispõe a

honrar a a eternidade do instante:

Zé Celso: Quando a gente montou o Gracias Señor, foi isso. Tinha acabado de rolar Rei da Vela, Roda Viva, Galileu, aí fizemos uma excursão pelo Brasil com o Galileu, Pequenos Burgueses e Rei da Vela. 22 pessoas. Com o dinheiro que entrava, a gente pesquisava o Trabalho Novo, primeiro trabalho de Te-Ato mesmo que a gente fez. Começou com uma série de ações em lugares pequenos, em pequenas aldeias que existiam no interior do Sertão, depois voltava pra capital pra fazer o espetáculo. Os espetáculos no litoral financiavam os do Sertão. Foi um trabalho de base com o silêncio. A gente chegou a ficar, por exemplo, 15 dias em comunidade, vivendo juntos, sem dizer uma palavra. Então a gente adquiriu uma capacidade de concentração absurda. (...) E o primeiro trabalho maior de Te Ato que a gente fez foi na Universidade de Brasília. Em plena ditadura, uma repressão enorme na Universidade, ninguém podia conversar nem falar nada. A gente foi pra lá e teve que fazer Pequenos Burgueses (...) A gente fazia 3 sessões de Pequenos Burgueses, e depois morava lá pela Universidade, em várias casas de estudantes. Mas todos ligados à clandestinidade, luta armada, aquela coisa. E naquela repressão doida, as meninas se vestiram assim e foram falar com o Reitor, que era um almirante, um cara da Marinha, super reacionário. (...) elas enrolaram o cara pra gente poder trabalhar. E a gente tinha uma sala, acho que era de arquitetura, encontrava todo mundo e planejava as ações de Te Ato. A gente percorria, muitas vezes em silêncio, todo o espaço da universidade, inclusive o subterrâneo, a parte de cima, a parte da terra mesmo. Por exemplo, íamos todos ao restaurante, com uma pergunta única. Aí, sentados em vários lugares, ao meio dia, ou numa hora qualquer, ao mesmo tempo, fazia aquela pergunta. Depois voltava a se encontrar. A gente percorreu a universidade toda, foi criando o trabalho. Aí, um dia, num mato de Brasília, a gente fumou muita maconha e nos maquiamos com o barro de Brasília. Era um espetáculo em que cada um ia com a roupa que estava, e nós fomos caminhando. E nos aproximando, vimos 7 nuvens no céu... A gente tinha deixado, assim, um recadinho minúsculo: "a tal hora e tal, não-sei-o-que-não-sei-o-quê, um encontro"... Aí a gente entrou. 22 pessoas. Cara, estava super lotado. Lotado. Tinha uns balcões, você via as pernas todas penduradas. Teve o aviso só no dia, mas eles já estavam cismados com aquelas pessoas caminhando por lá. Saiu uma foto da gente chegando no lugar, bonita, nós saindo do subterrâneo, de costas, foi um logo do Oficina, numa forma de bigorna, fizemos papel timbrado e uma série de coisas com aquilo, não sei onde está. A gente entrou caminhando assim e ia trabalhar os sete usos do bastão, uma coisa que se trabalhava em silêncio. Uma passagem, passava o bastão em silêncio. Era inspirado numa peça [Horácios e Curiácios, de Bertold Brecht], sobre muitos objetos num só objeto. E se a finalidade não fosse alcançada tinha que voltar. Ia passando em vários sentidos o bastão, como se fosse um remo, como se fosse estaca, enfím... E se alguém tivesse algum vacilo, tinha que voltar no começo até o final. Mas era mais que isso, era uma estrutura de espetáculo muito inspirada. E a primeira parte era em silêncio. A energia era tão grande que o meu braço ficava levantando assim, sem que eu quisesse. Era uma coisa muito forte. E toda primeira parte era em torno da careta, do legal, da carteira de identidade, que você tem um número e você é aquela carteira, mas ao mesmo tempo tem outra coisa por dentro que é invisível. A gente trabalhava exatamente em se comunicar com esta região das pessoas, não com a carteira de identidade. Isso era o silêncio. Mas a primeira parte introduzia tudo. Primeiro o paredão, que a situação nossa, por exemplo no Oficina, era de paredão, a polícia batia na gente, a gente não tinha como fugir, era horrível. E todo mundo tinha que enfrentar porque a situação era essa, depois do AI5. Aí a gente ficou no paredão lá da universidade, meia hora mais ou menos, só emanando e vivendo aquele 
instante, que era uma coisa que todos viviam. A repressão era muito violenta. Isso tudo em silêncio. Aí começava a peça com uma aula de esquizofrenia. Eu fazia um mestre que dava aula de esquizofrenia, e tinha o coro que introduzia... I love! I hate! Era muito engraçado. E era muito inspirado no 1984 também. Eu ia fazendo a aula de esquizofrenia até que um cara ficava doido, era o Flávio Santiago, aí ele era amarrado, ele era preso. E a gente tinha repolhos, que eram as cabeças, a gente punha os repolhos e perguntava se devia fazer a lobotomia ou devia continuar o trabalho. Lobotomia é uma coisa inventada pelo Eder Muniz, que é um cientista português, que é a separação do cérebro frontal do cérebro arcaico. $\mathrm{O}$ cérebro arcaico é de onde vem os sonhos, a arte. E o cérebro frontal ele corta, simplesmente. Aí perde. (...) aconteceu com nosso ator principal, o Henricão, um sujeito lindo, alto, loiro, maravilhoso, que fazia a peça com uma intensidade, era o próprio catalizador de tudo. Além do Renato Borghi, da Ester Góes, tinha uma porrada de gente boa. (...) A gente se enforcava, fazia uma série de coisas. Prendia o cara, com os repolhos, e perguntava: continua o trabalho ou lobotomiza? Afinal ele era lobotomizado, cortava o repolho, a gente esmagava como se fossem os cérebros... (...) Aí começava os sete usos do bastão. A gente mergulhava e ia pra cima. O espaço era dividido em 3 , a parte de cima era o sonho, a parte da terra, a realidade, digamos, e a parte de baixo era o subterrâneo. Passava pela parte de cima, que era um delírio, loucura total. Depois descia para o subterrâneo, que era tortura, tudo subterrâneo... Saía do subterrâneo e ia com a multidão toda, já era escuro, e a gente cantava enterrando o bastão. (...) E a gente foi fazendo isso em vários lugares. Que era essa coisa de tentar tirar os clichês todos e entrar nesse entendimento através do Te Ato. Que era a única coisa que se podia fazer. Porque era época de repressão e as pessoas falavam muito pouco. As pessoas se comunicavam por telepatia, ou não telepatia, mas pelo inconsciente mesmo. (...) As pessoas das comunidades, que na época se vivia muito em comunidade, elas começavam a participar do processo. Do Trabalho Novo. Que foi encenado, realmente, primeiro no Rio de Janeiro, no Teatro Teresa Rachel, onde tinha um show da Gal, Fatal, uma vez só, depois a gente foi pra um teatrinho pequeno, e a peça inclusive fazia muito sucesso, Gerald Thomas era menino e foi, o Pessoal do Asdrúbal, Gustavo Doria, muitos artistas iam, Caetano, Wally Salomão, foram várias vezes. E muito público, muito público. E era um trabalho todo, ou a maior parte, em silêncio, principalmente o segundo ato, porque tinha o primeiro ato que era o da lobotomia - o meio impõe a mensagem, que era a tortura, e o marketing, também impõe... não lembro exatamente. Mas enfim, esse ator - que foi lobotomizado quando a gente foi pro Rio, o Henricão - ele se lambuzava todo de produtos, enfim... O corpo ia sofrendo essas coisas todas, os nossos corpos. (...) E depois da coisa da tortura, veio a publicidade, o meio é a mensagem, o meio impõe a mensagem. Não lembro exatamente, mas era uma coisa muito bem urdida, o texto. (...) E aí, na segunda parte a gente morria. (...) eu lembro que uma vez que o Mário Schemberg, que era um cientista, a gente estava no Teatro Ruth Escobar, ele me botou nas costas e subiu. Mas ele já era velho, ele subiu a escadaria e me deixou lá fora. E eu, firmão. (...) Aí, na segunda parte a gente sonhava. E tinha o sonho da união dos corpos, uma cena que a gente ia com o bastão e fazia dois grupos que se encontravam e quem estivesse na frente se beijava, se abraçava, e, por dentro, o Henricão, com uma haste, como se fosse um falo, ia penetrando esses corredores das pessoas se amando, ia penetrando, ia percorrendo o espaço todo como se fosse a Barca de Serafim. Eu me lembro que uma parte subia pro espaço superior e outra parte ficava no espaço inferior, ali onde a gente fez o espaço cênico dentro do Teatro Ruth Escobar. (...) ficou assim como quem arranca um dente do espaço. Todo fodido. Era uma vela enorme, uma camisa de força que ao mesmo tempo era uma vela de barco. Era assim no Rio, também. No Ruth Escobar não tinha nada, só uma torre de campo de concentração, que ficava em cima, e uns detalhes, umas placas "É proibido cuspir" (...) Em São Paulo a gente fazia em duas vezes: a gente morria, aí, no dia seguinte, começava no sonho. Que era esse sonho de Serafim, uma parte ia pra cima, a outra ia pra baixo, e aí tinha um momento que se lançava uma corda, que era segurada pelas pessoas, e as de cima vinham e desciam por essa corda, quer dizer, só com a força humana. Aí chegava embaixo e era toda uma coisa amorosa e tal, a gente fazia um grande círculo, entrava uma vitrolinha tocando Wagner, a gente ouve também e contagia. A gente pedia e as pessoas vinham dizer nomes de desaparecidos, de pessoas que não estavam lá. E logo depois vinha a segunda parte. Aí era a liberdade inconsciente absoluta, amorosa e coisa. E a segunda parte era exatamente a guerra. Era tudo inspirado em Serafim Ponte Grande 
[obra de Oswald de Andrade]. (...) A gente entrava possuído. E no que a gente entrava, a gente já levava. E no que a gente morria, a gente estava todo no espaço, era puro, o espaço era possuído pelo nosso coletivo. E a gente tomava tudo. Tudo, tudo tudo que a gente podia tomar. Mas não era abstrato, é super concreto e palpável. $\mathrm{Na}$ época, era uma repressão doida, não se podia fazer nada, então era tudo pelo silêncio... Tinha uma banda, tinha música e tal, se cantava alguma coisa, principalmente na coisa do sonho, depois vinha o texto do Serafim Ponte Grande, que o Renato Borghi fazia. Ele fazia o discurso final, 'Tudo é Tempo e Contratempo', e era assassinado. Estava só de sunga, e era passado como o corpo do Tchê, assim, pelas pessoas, elas passavam o corpo dele pela plateia toda, as pessoas pegavam no corpo, então... A comunicação era táctil, e silenciosa, na maior parte. Aí, depois tinha o sonho da ressureição. A gente dava o bastão para as pessoas e fazerem coisas, elas se comunicavam através do bastão. Em silêncio, tudo. Era muito amarrado. Com palavras chave, de poder. Era bastante improvisado. Mas era um improviso que tinha uma estrutura forte. A gente trabalhou isso, de fazer improviso dentro da estrutura, mas sem palavras. Na época, todos, todo o público sentia a opressão. Então, quando ia pra lá, era uma des-repressão do inconsciente. A gente se comunicava exatamente com o não dito. Porque a gente começou se trancando no teatro Oficina por um mês, e cada um chegava e falava da sua careta, e depois a gente tentava trazer o inconsciente. Cada um falava da careta, dava sua identidade, dava seu número, e trabalhava o não dito. E isso foi levado ao absurdo. As pessoas não estavam doidas. Estavam doidas, sim, mas doidas no sentido de uma percepção muito grande de tudo. A ação era muito estruturada. E muito ligada no tempo também, porque tinha muita tortura nessa época, foi quando começou a tortura, depois do AI5. Tinha tortura, tinha clandestinidade, era um horror. (...) Nós fomos presos várias vezes. Uma vez fizemos as três peças em São Luís, Galileu, Pequenos Burgueses e Rei da Vela... Aí, acho que era Galileu, de repente acabou a luz, e nós aproveitamos e aplicamos o Trabalho Novo. (...) No dia seguinte, veio polícia e nos prendeu. E nos levou pro exército, pra saber como nós tínhamos aprendido a hipnotizar pessoas. Como o público atuava conosco mesmo sem a gente dizer uma palavra? Veio um médico me interrogar sobre como eu tinha descobertos aquelas técnicas. Até saiu um artigo, "Como eles agem", dizendo que nós hipnotizávamos o público e que tínhamos aprendido isso na China. (...) os censores queriam proibir a peça, mas os superiores de Brasília não proibiam porque queriam estudar o fenômeno. Aí, já no Teatro Oficina, foram 40 censores ver Gracias Señor. Eram 40, mas o teatro estava lotado, e todas as outras pessoas entraram no jogo da peça, só eles ficaram de fora. Só os censores não foram. Então eles piraram. E disseram que entrariam em greve se Brasília não proibisse. (...) [era como aplicar] Uma vacina antropófaga. Uma macumba antropófaga. A gente parou, acendemos umas velas e começou com o silêncio. Aí foi envolvendo, foi fazendo. A gente tinha o roteiro claro, era pleno, eram 22 pessoas (...) era fácil fazer porque a gente estava na construção disso, e nessa época havia uma ligação muito grande. (...) era um mergulho numa coisa que tudo é possível. Você cria uma espécie de um aquário do inconsciente de todo mundo que está presente lá. Aí você nada à vontade. Nós chegamos juntos [nisso] nesse mês que ficamos sentados no teatro vendo o que é máscara e o que não é máscara. E estudando a história do cérebro frontal e do cérebro arcaico. E usando drogas com tudo. (...) Porque eu acho que o teatro é uma atividade xamânica. Os grandes momentos do teatro são muito ligados ao Xamanismo, a origem do teatro é xamânica.

Zé Celso liga novamente o teatro ao xamanismo das substâncias psicodélicas, as mesmas que fizeram Fauzi intuir sua Alquimia. Há uma irmandade reveladora entre as duas abordagens. Sendo a Alquimia, basicamente, a arte da transmutação da matéria na própria quintessência, e o Xamanismo, a arte da cura pelo conhecimento da morte e dos caminhos entre os mundos manifesto e não manifesto, se o teatro é uma atividade xamânica, a alquimia do teatro se faz na consciência desse trânsito: 
Zé Celso: (...) Eu acho que tem muitos teatros. Tem teatro só representado. Tem teatro que não passa, que fica no drama, na comédia superficial, ou na comédia muito mental, tem uns caras brilhantes que são só mente, não tem corpo. Tem uma variedade muito grande. Por isso eu chamo de Te Ato a coisa de usar a representação só como uma máscara, porque o que a gente quer, e o que a gente tem que viver, é o aqui e agora. Trabalhar no nível do teatro xamânico. Ou alquímico. É o teatro ligado ao aqui e agora. Como o Marx Selvagem do Jean Antibe, que fala do Marx das comunas primitivas, e se inspira no verbo marxilar criado por Oswald de Andrade para sugerir que se devore Marx. Porque o grande antagonismo hoje não é o Capital e o operário, mas o Capital e os índios do mundo inteiro. Porque todo mundo é Indio. Sueco, alemão, todos foram índios um dia. E tem esse contato. Tupi or not tupi. Quer dizer, existe esse corpo tupi e o corpo to be. O corpo que quer ser. Que vive e quer ser. Que vive no ser. (...) [hoje o corpo é] capturado pelo sistema. Entra um sistema nele, e leva tudo pro cérebro. E se abandona o corpo. Tem que se descapturizar. Isso é um processo no qual eu estou cada vez mais radical, e os ensaios começaram a melhorar com essa radicalização, que é no sentido do teatro xamânico. Do canto xamânico, a paixão das palavras...

\title{
CATÁBASE II
}

1972, pouco tempo depois dos episódios narrados pelos dois ex-parceiros, aos 35 anos, Fauzi é uma estrela da cultura local. Ou da contracultura histórica nacional. Diretor de peças e espetáculos, cataliza sua geração espontaneamente. Nunca trabalhou na Globo, mas quando estreia algum espetáculo, é capa dos cadernos de cultura. Tem poemas repetidos pelas fogueiras hippies do Brasil, decorados nos shows de Maria Betânia. Mas nada disso é planejado, são decorrências naturais de escolhas despretensiosas e bem particulares, algumas surpreendentes numa perspectiva atual do que seria um "profissional do teatro."

A certo ponto, parece bem mais ocupado com os estudos e a prática da psicologia do que com algum projeto artístico. Ou político:

\begin{abstract}
Não havia em mim uma ambição de conhecimento pelo poder, mas ela era mais uma atitude de defesa (...) Meu eu mais verdadeiro já não se satisfazia com um mergulho raso na coisa artística, mas sentia sede da compreensão mais total, e me parecia urgente decifrar a realidade que me cercava, e que era totalmente ignorada por aqueles que no passado eu elegera como mestres ou guias. (...) no passado [eu] amara o Teatro, com todo seu mistério e magia, e esse amor me conduzira a um aprofundamento, agora o que se punha como desafio era essa atração pelo Desconhecido dentro da própria vida, que eu vislumbrara e do qual não queria abrir mão. (ARAP, 1998, p.104)
\end{abstract}

Talvez a vida dele, naquele momento, possa ser lida como um trabalho artístico e político: a ditadura oprime, mas Fauzi já conhece a morte - usou a condição de artista para ter esse conhecimento em vida; e flutua na força, como Dioniso no útero de Sêmele. O show Rosa dos Ventos já faz sucesso há algum tempo, garantindo mais do que as contas pagas, toda 
energia da alquimia ativada pelos símbolos do espetáculo. E na vida real do dia a dia, Fauzi se dedica a contracenar com as profundezas da alma humana. Além da própria, também a dos outros - a ponto dele se tornar colaborador da psiquiatra Doutora Nise da Silveira, a quem admira pelo trabalho ligado ao pensamento de Jung. Entre 1970 e 1972, dá aulas de teatro para pacientes psiquiátricos na clínica Casa das Palmeiras, Rio de Janeiro. O encontro do artista com a médica acaba se revelando um enigma poético:

(...) fui recebido por uma secretária, que pediu que eu aguardasse e desceu para avisá-la de minha chegada. Eu ainda não sabia do enorme número de gatos que ela mantinha ali, e quando me vi cercado por quarenta deles, sem exagero, posicionados por toda parte, na mesa, nos sofás, cadeiras, e em cima dos móveis, todos me encarando como que a um intruso, não pude deixar de me sentir num filme de terror. (...) Para meu alívio, ela finalmente me recebeu, e houve entre nós uma empatia imediata, quase um amor à primeira vista. Além disso, uma de suas gatas logo instalou-se em meu colo, e Nise me informou tratar-se da madre superiora das outras e que aquilo indicava um sinal de aprovação. (...) (ARAP, 1998, p. )

Definida a colaboração, o ex ator - agora só diretor, além de novo terapeuta artístico na Casa das Palmeiras - muda novamente para o Rio e começa a trabalhar na clínica duas vezes por semana. Leva o trabalho a sério, o depoimento mostra uma visão profunda e envolvimento quase passional. Fauzi parece ter se alinhado ao sentido etimológico da palavra terapeuta, em grego "therapeuein", curar, significava, originalmenle, "serviço aos deuses". (...) Portanto, psicoterapia significa, em termos essenciais, serviço à psique.” (EDINGER, 1995, p.22) Ou seja, ele servia àquela dimensão infinita dentro de si mesmo que tinha dominado sua vida. Ele narra um episódio numa de suas aulas, quando um helicóptero sobrevoou o prédio pela segunda vez enquanto os alunos faziam o exercício de repetir a letra "M" vibrando as caixas cranianas. Surpreendendo a todos, o mesmo homem misterioso que antes dissera as palavras "Mare Nostrum” tem um ataque de riso incontrolável. Depois, estimulado por Fauzi, fala pela segunda vez: - É uma piada que Ogum me contou lá fora... De um homem que pegou um helicóptero, e foi embora, partiu... E aí encontrou uma pedra preciosa e nunca mais quis voltar. (ARAP, 1998, p.150)

Espantado, Fauzi lembra da outra única vez que o homem falou alguma coisa em latim, e sua mente associa a imagem da "pedra preciosa" à ideia da pedra filosofal dos alquimistas. Ao mesmo tempo, a figura de Ogum situa a realidade contemporânea e mostra uma "superposição de dois tempos distintos", o do paciente "alquimista" conhecedor do Mare Nostrum e o do carioca nos anos 1970. "Aquilo que poderia ser considerado apenas uma 
confusão era, para mim, um sinal de que todo símbolo resulta atemporal em sua expressão e por isso passível de ser justaposto a outro distante, no tempo e no espaço.” (ARAP, 1998, p.)

A imagem sugere uma possível realidade paralela na vida do homem silencioso, que seria aquele paciente psiquiátrico, tranquilamente preso em seu Mare Nostrum particular, e ao mesmo tempo um alquimista com a bênção de Ogum, navegando a bordo de sua "pedra filosofal".

Uma outra paciente, em especial, é determinante no rumo da experiência. Ela tem mais ou menos 30 anos e não exibe, a princípio, qualquer distúrbio mental. Mas logo se percebe que só fala por frases feitas, ou pergunta se fadas não existem mesmo, sempre com um risinho idiota preso na boca. Um dia, no segundo ano de aulas, depois de um processo terapêutico que Fauzi conduz com capricho totalmente experimental, ela pede uma conversa a sós e diz o seguinte: "É como se tivessem derrubado todos os meus escudos, é como se tivessem rompido minha couraça... e todas as minhas defesas, e é como se eu fosse um barco e estivesse levantando âncora." (ARAP, 1998, p.178)

Se não fosse uma paciente diagnosticada com oligofrenia extrema, poderia ser uma declaração pessoal. Mas Fauzi sente que é uma cura encaminhada. E fica muito satisfeito com o resultado positivo. Porém, depois disso, ele precisa fazer uma viagem de trabalho (uma turnê do Rosa do Ventos na Bahia), e quando volta, é informado que aquela paciente tinha tentado suicídio. E a notícia traz implícita uma acusação velada.

Ele tenta marcar uma reunião com Dra. Nise na clínica, junto a outros médicos, mas ela marca no apartamento onde vive com os gatos. Fauzi leva um dossiê sobre o trabalho, resultado de uma dedicação metódica, desenvolvida na faculdade de engenharia. Traz especialmente organizados os casos que identifica como possíveis curas:

A gata, madre superiora da casa, que se sentara em meu colo no primeiro encontro
em sinal de aprovação (...) vai e senta-se justamente sobre a pasta que continha
todas as minhas propostas. O tempo passava e nada de se começar a reunião. Nise
não permitia que se retirasse a gata de onde estava. Eu ainda imaginava que a certa
altura, por cansaço, se tomaria a providência (...) não. Eu estava assistindo ao vivo a
mais uma das histórias sobre o respeito desmedido de Nise por seus gatos. (...) pura
loucura. (...) aquela gata, com certeza refletia o desejo de Nise ou de todo o grupo
de que não houvesse reunião nenhuma, e não se discutisse coisa alguma. (...)
ninguém se importava com isso. Acabei afirmando de forma explosiva que, já que
era assim, o correto seria o meu afastamento. (ARAP, 1998, p.182).

O acontecimento marca o final de um percurso trilhado com amor e dedicação, mas coroado com a dúvida, a culpa, uma rejeição sem sentido lógico e o sentimento de injustiça. E 
não é a única invertida que Fauzi toma na mesma época, no mesmo sentido. O que estava em curso era a segunda morte dionisíaca de Fauzi, e esta, ao que parece, seria uma morte dupla.

Enquanto trabalhava na Casa das Palmeiras, Fauzi já havia reencontrado uma forma de voltar a seus estudos de autoconhecimento com o LSD:

Vez por outra eu continuava fazendo minhas viagens diante da máquina de escrever. (...) aquela máquina era como que um pequeno altar, ponto de referência e âncora para que meu propósito de autoconhecimento prevalecesse. A estrutura de cada viagem se repetia, a cada vez. De início, antes que eu me desprendesse de minha consciência habitual, cotidiana e pessoal, eu era invadido por muito medo, quase um terror. Até que um sentimento amoral e selvagem me possuía, como que me preparando para alçar vôo e cruzar a fronteira. E logo, numa fração de segundo, eu já me descobria penetrando enfim o mundo desconhecido de energias e imaterialidade, que começava a aprender a conhecer. Eu mantinha, diante de tudo, uma entrega e docilidade. Eu ia aceitando o reconhecimento do material que aflorava (...) ia vivendo tudo com relativa naturalidade. Eu só cuidava para que meu retorno à esfera do mundo da normalidade não deixasse de acontecer, e mantinha o cuidado de não comentar aquilo com ninguém. (ARAP, 1998, p.158)

Este "cuidado de não comentar" se deve certamente ao duro aprendizado que foi para Fauzi a superação do estigma que ele enfrentou entre 1964 e 1965, e que seria evitado se ele estivesse atento à ancestralidade do teatro em relação a esse tipo de estudo, como observamos no capítulo Teatro Nuvem.

No final do intenso ano de 1971, Fauzi encontra o diretor Zé Celso Martinez Corrêa em algum bar em Copacabana, e este, sabendo dos caminhos do ex-parceiro pela psiquiatria, pede que ele trate de um ator do Oficina que está em surto, justamente o grande corifeu Samuca. Os depoimentos de Fauzi e Zé Celso sobre o momento em que o ator pirou divergem, mas não essencialmente:

Contam que sua loucura se instalou de forma superteatral. No dia em que estranharam seu comportamento pela primeira vez, permaneceu de pé, sem se mexer, e sem dizer palavra, por duas horas ou mais, na porta do escritório do velho Teatro Oficina. (...) Nos dias seguintes, ele continuou com seu comportamento estranho, como se quisesse provar alguma coisa com seu silêncio, e como se a própria vida fosse um grande laboratório teatral. (ARAP, 1998, p.204)

Não consta o diagnóstico preciso do distúrbio, mas sim que Samuca se tornara usuário pesado de drogas, principalmente o LSD. E isso, naquele momento, parece tocar o coração de Fauzi: "A culpa me invadia por me sentir co-responsável pela desintegração pública dos últimos hippies que circulavam miseráveis pelas praças, perdidos, diante do fim do sonho. (ARAP, 1998, p.213)

O sentimento de culpa narrado por Fauzi parece realmente infundado, mas chama atenção para a responsabilidade do artista como "formador de opinião" ou modelo de 
comportamento para seus admiradores, algo muitas vezes totalmente desconsiderado por quem tem a chance de exercer este papel. Certamente Fauzi não tem responsabilidade alguma sobre os descaminhos lisérgico de sua geração, ao contrário, se sua atitude perante o LSD fosse adotada por todos que o utilizam, muitos problemas seriam evitados. E o caso de Samuca, ao que parece, vai além da questão do abuso da substância, como dá a entender o depoimento de Sérgio Mamberti, que se tornou próximo do ator quando este se casou com sua ex-cunhada, a atriz Walquiria Mamberti:

Sérgio Mamberti - O Samuca também era um ator absolutamente fantástico, só que depois ele realmente foi, e não conseguiu voltar. Ele ficou num outro plano. Mas não foi só o ácido, foi também muita sensibilidade. (...) Eu cheguei lá, bati na porta do apartamento, aí veio o Samuca me atender. Aquele cabelão que ele usava, enorme. Tudo escuro. Eu vi uma luz bruxuleante lá dentro, pensei, “deve ser luz de lampião, não deve ter pago a luz." aí eu fui entrar e pum, bati a cabeça numa coisa. Eu falei: "Que é isso, Samuca?" Eu olhei e era um fio, e tinha um vidro, e tinha uma coisa com água dentro de um vidro. Ele falou assim: "É que eu fiz uma cirurgia de menisco e esse é o meu menisco... E aí eu olhei no chão, estava sem taco, eles estavam usando os tacos como lenha, cozinhando com os tacos, tinha uma cômoda antiga do meu irmão, a cômoda já estava pela metade. Ele, o meu sobrinho, o Caio, e a Walkiria vivendo naquela loucura. Aí eles fizeram a excursão com o Zé. E, na volta, não tinham lugar pra morar. Então eles vieram morar aqui. Minha casa virou uma espécie de comunidade. E aí eu me lembro que uma noite eu sinto um cheiro de queimado em casa, quando eu chego lá embaixo - eu tinha 2 poltronas gorduchas assim, elas estavam velhas já, então tinha uns buracos na poltrona, ele pegou o cigarro, não sei o que foi, ele tocou fogo naquilo. Então estava aquele braço da poltrona em brasa, e o Samuca sentado e olhando aquilo, sabe? E aquela fumaceira! Ele falou assim: "Vem cá, vem cá! Ó, ó, ó!” mostrando, assim. Eu falei: “Cara!” Fui na cozinha peguei um copo, joguei água. Falei: "Samuca, pelo amor de Deus!" Ele falou assim: "Vem cá ver." Tinha um buraquinho na parede e ele falava: "Olha! Olha! Tá vendo? Tá vendo?” Ele via coisas através daquele buraquinho na parede.

Mais tarde, em 1975, Samuca e sua história inspiram a criação do protagonista mudo do primeiro texto do Fauzi, Pano de Boca, a personagem Pedro, um ator que para de falar até virar uma Esfinge. Três anos antes da peça, em 1972, depois de relutar um pouco para aceitar a tarefa solicitada pelo ex-parceiro, um dia o autor encontra Samuca na rua, com sequelas aparentes de uma internação recente. A imagem termina por formar sua decisão:

Naquele momento começava a existir à nossa volta, pelas ruas e praias do Rio, o triste espetáculo de muitos jovens se destruindo por causa das drogas e de seu estilo de vida radical, que pretendia estar acima da vida do comum dos mortais. E foi dessa forma que acabou nascendo a ideia de realizar um psicodrama público do que seria a loucura auto-provocada pelos drogados. (ARAP, 1998, p.205)

Fauzi resolve atender ao pedido de Zé Celso. Junta uma força tarefa e inicia uma série de reuniões, primeiro em seu apartamento. 
(...) como num teorema que se demonstra por absurdo, as reuniões seriam abertas, e sempre caberia mais um. De certa forma eu representaria papel da consciência de cada um (...) E eles mesmos, cada um, representariam as forças irracionais do inconsciente, os chamados complexos psíquicos, que podem eventualmente se organizar com a força de um eu, e perturbar e destruir a saúde mental de um indivíduo. Eu pretendia demonstrar como esse tipo de atitude, mais cedo ou mais tarde, só poderia conduzir ao caos. (ARAP, 1998, p.206)

Ele se envolve, usa o que sabe e faz o que pode. As sessões começam como psicodramas e laboratórios e as primeiras semanas vão bem. Depois de uma pequena melhora de Samuca, o grupo se anima e as reuniões passam a acontecer no Teatro Glauce Rocha, com o objetivo de poder atender mais pessoas. E elas vêm chegando. $\mathrm{O}$ depoimento não diz quantos eram, mas pelo jeito era bastante gente. Mas, algum tempo depois, Fauzi começa a perceber que aquela situação é que "só poderia conduzir ao caos".

Não percebi, naquele momento, como estava superestimando minhas forças, envolvido por uma pressão ambiente que não era dirigida apenas ao terapeuta amador, mas também ao diretor do enorme sucesso que era o show Rosa dos ventos (...) Talvez boa parte deles imaginasse que eu fosse criar um espetáculo, talvez fosse isso. (ARAP, 1998, p.206)

Além das "segundas intenções" patente no interesse profissional de parte dos frequentadores, surge a proposta de uma reunião paralela para se trabalhar a partir do Espiritismo. Fauzi concorda, a contragosto, talvez porque ele mesmo tivesse dado abertura para isso ao comentar sobre suas investigações nos anos anteriores - que incluíam passagens pelo Espiritismo, Candomblé e Rosa Cruz. Ele não queria ser autoritário. Além do quê, depois de uma melhora inicial, houve um Carnaval no meio do caminho, e Samuca teve uma recaída e não se recuperava. Se não bastasse isso, toda a atividade leva Fauzi a uma mudança de hábitos delicada:

Talvez tenha sido quando Samuca teve a recaída que decidi parar com as drogas e dar o exemplo. É bom lembrar que o LSD (...) não vicia nem cria qualquer tipo de dependência física. (...) o LSD conseguia me obrigar, através de seu desafio, a prestar atenção em mim, e no processo eu encontrava respostas (...) era um dos pilares do novo estilo de vida que eu adotara, que também incluía toda uma disciplina (...) o veículo que me facultava o aprofundamento necessário para fazer leituras da realidade descondicionadas do senso comum, criativas e surpreendentes, e com excelentes resultados (...) o símbolo de meu recolhimento e concentração possíveis (...) imprescindível para que eu pudesse manter aquele estado de consciência diferenciado, que vinha me permitindo ajudar e compreender o próximo. Ao deixa-lo de lado, impensadamente, cortei um dos hábitos fundamentais que haviam gerado meu novo equilíbrio. (ARAP, 1998, p.208)

Eu não percebi, senão tarde demais, que aquele estado particular de consciência que eu atingira deveria obedecer a um outro tipo de ética, mesmo que eu não soubesse qual. E precisaria ser cuidado, para ser mantido. A energia excepcional de que eu dispunha naqueles dias não caíra do céu, mas havia sido conquistada, a cada passo, às custas de muito esforço e determinação. (ARAP, 1998, p.211) 
O fato é que o trabalho de cura que Fauzi deseja fazer com o grande corifeu do Oficina não dá certo, e isso é um baque:

\begin{abstract}
A reunião final foi marcada por uma explosão minha (...) expulsando a todos a quem eu, de certa forma, prometera ajuda. Com mais equilíbrio, eu poderia ter dito as mesmas verdades com alguma delicadeza, mas meu comportamento foi quase demoníaco (...) não suportava mais tentar fazer todos esses papéis ao mesmo tempo, professor, psicólogo, diretor, guru, nem tentar atender os desejos e as necessidades conflitantes de cada um deles. Foi terrível e traumático. E não só para eles. Tenho a impressão de ter consumido muitos longos anos convalescendo daquele amargo rompimento. (ARAP, 1998, p.210)
\end{abstract}

Para melhorar, este amargo rompimento não vinha sozinho. Ao mesmo tempo, havia o fim da grande "lua de mel" do show Rosa dos Ventos: "Crises mais ou menos profundas com Bethânia e Flávio me obrigavam a reconhecer que havia projetado sobre os dois qualidades impossíveis" (ARAP, 1998, p.211); havia ainda o cruel desencanto e o fim da colaboração com Dra. Nise, na Casa das Palmeiras; e havia finalmente a interrupção das "sessões lisérgicas" solitárias diante da máquina de escrever:

Nem por um momento me ocorreu que minha abstinência faria desaparecer aquele sujeito corajoso e incansável no trato dos problemas surgidos, tão identificado eu estava com aquela nova forma de ser. Aos poucos, aquele ser quase etéreo que flutuava pelas ruas do Rio, guiado apenas por sua intuição, desapareceu. (ARAP, 1998, p.205)

A situação, na verdade, confirmaria a possível emanação do arquétipo dionisíaco, com suas duas mortes. O mito vingaria mesmo no mundo racional, linear e causal, onde a linguagem dos símbolos se confunde com a poesia pura. Fauzi morre novamente. Se da primeira vez morreu o ator, agora, de outro jeito, morria o terapeuta (que ele talvez fosse tão bom quanto foi ator, não saberemos) e, mais do que isso, talvez mais importante, embora as duas coisas sejam, na verdade, uma coisa só: morria o psiconauta, o navegante contumaz do Mare Nostrum.

Nem mesmo meu rompimento com a roda-viva que me afastara de meus trilhos ideais me fez voltar ao LSD, e também por ter me afastado da Casa das Palmeiras, a retomada daquele estilo de vida inicial já não era possível. O sucesso do Rosa dos Ventos já tinha um sabor amargo (...) Não era fácil compreender como tudo desandara, e eu perdera a confiança em mim.(ARAP, 1998, p.213)

Mas não bastava morrer, Fauzi queria exterminar:

A desesperança que me cegava me levou a re-introjetar todos os valores caretas do mundo compartimentado, que nunca me haviam servido, e comecei a procurar uma forma de caber no sistema, tal como ele era. Pensei em mudar de profissão, e 
oficializar minha relação com a Psicologia (...) Cheguei a procurar um cursinho (ARAP, 1998, p.214)

Talvez ele se sentisse como se sentiria uma criança, no ventre da mãe mortal, sendo fulminada pelos raios de um pai divino. Ao que tudo indica, Fauzi passava por um processo que a Alquimia tradicional chama de Mortificatio, a morte psicológica, inescapável no caminho da matéria, ou da psique, para sua transformação em ouro. Morte que pode acontecer mais de uma vez no processo "alquímico" da individuação, quando se tem a oportunidade de passar para a fase seguinte no caminho evolutivo.

\begin{abstract}
A alquimia representa a projeção de um drama ao mesmo tempo cósmico e espiritual em termos de laboratório. A opus magnum tinha duas finalidades: o resgate da alma humana e a salvação do cosmos... Esse trabalho é difícil e repleto de obstáculos; a opus alquímica é perigosa. Logo no começo, encontramos o "dragão", o espírito ctônico, o "diabo" ou, como os alquimistas o chamavam, o "negrume", a nigredo, e esse encontro produz sofrimento... Na linguagem dos alquimistas,a matéria sofre até a nigredo desaparecer, quando a aurora será anunciada pela cauda do pavão (cauda pavonis) e um novo dia nascerá, a leukosis ou albedo. Mas nesse estado de "brancura" não se vive, na verdadeira acepção da palavra; é uma espécie de estado ideal, abstrato. Para insuflar-lhe a vida, deve ter "sangue", deve possuir aquilo a que a que os alquimistas denominam a rubedo, a "vermelhidão" da vida. Só a experiência total da vida pode transformar esse estado ideal de albedo num modo de existência plenamente humano. Só o sangue pode reanimar o glorioso estado de consciência em que o derradeiro vestígio de negrume é dissolvido, em que o diabo deixa de ter existência autônoma e se junta à profunda unidade da psique. Então, a opus magnum está concluída: a alma humana está completamente integrada. (JUNG, apud Edinger, 1995, p.62)
\end{abstract}

Nessa perspectiva, se consideramos que a trajetória de Fauzi foi uma de suas "alquimias", a Nigredo seria a fase do stigma, a Albedo seria a fase "só diretor", e a Rubedo seria o resto de sua vida a partir do momento em que se completou como artista ao se tornar dramaturgo.

Mas antes da Rubedo, naquele momento, Fauzi sentia que alguma coisa tinha morrido. $\mathrm{Na}$ verdade, anos depois ele encontrou uma forma mais adequada para aplicar seu talento para a cura psíquica através da astrologia. Segundo consta, ajudou muita gente. Mas naquela hora ele precisava direcionar a energia. Precisava de mais essa morte pra chegar à compreensão do papel da arte como único meio de resolver sua ânsia por retribuir ao mundo uma sabedoria que a vida tinha posto na mão dele. Num dado momento ele percebeu: "Foi então que decidi escrever, como forma de sobrevivência psicológica.” (ARAP, 1998, p.214)

Fauzi renasceu, finalmente, dramaturgo. A peça Pano de Boca (1974), seu texto de estreia, coroa a alquimia de um ator transmutado em autor, e se configura o registro de uma experiência tão pessoal quanto coletiva, devidamente transmutada em cena. A personagem 
Magra é uma atriz em crise que no final do primeiro ato diz a um interlocutor invisível: "Eu acho estranho as pessoas não temerem a palavra. Ela é uma coisa mágica, eu acho até que é a coisa mágica.” (PANO DE BOCA, 1,57)

Esse respeito pela palavra se mostra chave numa trajetória que tem sua conclusão "alquímica" com o nascimento do dramaturgo, entre as funções criativas do teatro, a mais ligada à palavra, seu primeiro criador, e o segundo seria o ator. São silêncios em série: o terror de Estado cala as vozes dissonantes; o grande corifeu silencia; a personagem do Pano de Boca silencia; Sérgio Mamberti silencia na Última Peça; Zé Celso cria uma linguagem no silêncio. E Fauzi cria novas palavras:

\begin{abstract}
A palavra falada envolve a percepção simultânea da emoção do ouvinte, e em parte é dirigida por ela, enquanto a palavra escrita exige que se busque uma objetividade impessoal, se possível, no esforço de circunscrever ideias e fatos, relatados através da coisa apenas literária. Todo o processo foi me ensinando a discernir entre as duas coisas, o que me era fundamental para decifrar os mal-entendidos verbais que eu vivera nos idos de 63. Eu era um especialista quase nato, intuitivo, no terreno da palavra falada, o que descobrira atuando como ator e diretor. Agora o desafio era aprender a capturar a interação emocional que existe entre personagens ou pessoas, através do diálogo escrito. Como no passado eu sempre permitira que o emocional interferisse na clareza de minha expressão, eu estava agora situado num espaço adequado para alquimicamente elaborar minha dificuldade. (ARAP, 1998, p.218)
\end{abstract}

A personagem Magra advoga o mesmo que o autor, que a arte é sua forma de compartilhar certas qualidades de vivência, por ser o único terreno onde a Consciência e o Inconsciente se entendem perfeitamente. A arte seria o "espaço adequado para alquimicamente elaborar” dificuldades. Noção que Fauzi parece ter conquistado à unha: “...minha peça discutia meu passado de ator, eu mesmo perdido em meu silêncio diante da dificuldade de comunicar as verdades que percebera." (ARAP, 1998, p. 218)

\title{
TUDO MITO
}

A autoridade artística de Fauzi e sua obra são observados neste estudo como objeto de conhecimento, um legado cultural importante, poemas, peças que serão remontadas, livros que serão estudados. E essa ideia de um legado, em si, tem a ver com história do herói, que Jung identificou na mitologia universal como um dos arquétipos fundamentais da psique. São padrões ancestrais ativos nos bastidores da consciência, e o herói é o arquétipo do fundador de alguma coisa, uma cidade, uma religião, um time: "Para fundar algo novo, ele deve abandonar 
o velho e partir em busca da ideia semente, a ideia germinal que tenha a potencialidade de fazer aflorar aquele algo novo." O protagonista do mito é alguém que "descobriu ou realizou alguma coisa além do nível normal de realizações ou de experiência, e deu a própria vida por algo maior que ele mesmo." (CAMPBELL, 1998, p.150/37) Na psicologia analítica, o Herói é o arquétipo das conquistas humanas, por isso é natural que existam paralelos entre as narrativas heróicas e a trajetória das pessoas que fizeram alguma coisa útil da vida.

A estrutura básica do mito define o arquétipo: tipicamente começa com alguém saqueado pelo destino, inspirado a resolver questões da sociedade, parte numa aventura para recuperar o que se perdeu ou para descobrir o elixir que resolve a questão. É o arquétipo das vitórias da alma, algumas de impacto, outras consagrando heróis de si mesmos, da família, dos amigos. $\mathrm{O}$ arquétipo se realiza na ação das pessoas, e o mito é um filtro mágico que revela o que há de eterno na concretude.

Muitos caminhos guardam relações simbólicas em variações infinitas com as aventuras míticas, mas poucos se completam. A confirmação do herói é o elixir conquistado e compartilhado em comunidade: uma libertação, o resgate da normalidade, a vitória contra o mal, o herói traz o elixir que resolve a questão. Fauzi não tirou a Excalibur da pedra nem inventou o avião, mas o epíteto de "mais desconhecido dos grandes artistas brasileiros" indica que talvez tenha realizado alguma coisa "além do nível normal de realizações e experiência". Talvez a morte prematura do ator tenha a ver com dar a vida por algo maior que ele mesmo. Se hoje sua obra é objeto de conhecimento, de alguma forma, ele trouxe seu elixir:

Minha primeira peça, Pano de Boca, acabou funcionando como um verdadeiro
curativo sobre as feridas dos hippies remanescentes. Lembro que, no Rio, depois da
estreia, alguém me cochichou ao ouvido: "Obrigado por tê-la escrito por nós", e esse
"nós" muito me gratificou, por mostrar que a coragem do mergulho solitário que eu
empreendera acabara por dar seus frutos, permitindo que eu reencontrasse meus
companheiros em outro nível. (ARAP, 1998, p.235)

Em termos materiais, o elixir de Fauzi são 16 textos teatrais, alguns poemas, os roteiros dos shows de Bethânia, e o livro depoimento Mare Nostrum. Menos materiais são as memórias e os conhecimentos trocados nos ensaios, com os parceiros que dão aula ou atuam e dirigem passando adiante a experiência. Numa sociedade infestada por monopólios que pretendem controlar o próprio conteúdo da arte, a trajetória de um artista original que conquista seu espaço e dá seu recado em escala razoável na cena cultural é em si um ato político. Fauzi realizou muitos papéis, direções e textos de impacto durante uma ditadura 
militar castradora e sanguinária. Fenômeno espontâneo, ocupou o imaginário coletivo com versões libertárias da realidade, fora das narrativas oficiais. Conquistou cedo autoridade artística para ser um criador livre, fiel ao próprios critérios, temáticos, estéticos, dinâmicos. Ocupou espaço sendo essencialmente profundo e questionador, contra uma tendência geral da superficialidade na cultura de massa. Numa sociedade ainda rígida, sob a influência da Guerra Fria com sua narrativa forçando os desejos como nos filmes, histórias claras, protagonistas definidos, espaço tempo linear, individualismo, relações românticas heterossexuais... Nesse contexto, a relação de Fauzi com o próprio Inconsciente foi intensificada a mil graus pelo LSD. E a partir de uma experiência potencialmente perigosa, que poderia desestruturar definitivamente sua psique, ele aprendeu a compreender a natureza dessa experiência, da eternidade e da morte, e transformar em qualidade na arte. Qualidade que ele sempre teve, na verdade. Diz a alquimia que é preciso ouro para fazer ouro.

Quando descreve em seu depoimento seu caminho do choque com o Inefável até a dramaturgia, Fauzi sugere como se navega pelo Mare Nostrum e como se escreve sobre isso. E lega o elixir da inspiração para estas e outras reflexões, legado indireto que se prolonga nesse estudo: o pensamento sobre Fauzi é parte do elixir. A decodificação de seu criptograma. O cultivo do seu campo espacial para a sequência não linear de uma Alquimia do Teatro. A investigação sobre um artista, esse artista ou algum tipo de artista, ser ou não ser aquele xamã visionário, que traz à tona as imagens que, só assim, cabem no mundo.

\section{DOCE ALQUIMIA}

Na página 283, no centro do capítulo 20 do Mare Nostrum, nomeado "o teatro da alquimia e a alquimia do teatro", o autor formula a seguinte síntese: "Tudo o que nos cerca é simbólico. Trata-se de aprender a ler" (ARAP, 1998, p. 238). As frases fluem tranquilas no tom testemunhal do texto, mas ao pé da letra, compõem uma afirmação bombástica sobre a existência de uma espécie de linguagem do inconsciente camuflada na forma espontânea da realidade cotidiana, disponível para decodificação. Abre a perspectiva fascinante de uma experiência de todo campo de percepção como linguagem, uma possível utopia psíquica. É um exagero libertador. As imagens do cotidiano vistas como cartas de um baralho de tarô desenhado na alma, um enigma decifrável pela chave da percepção do jogo de forças 
subjacente à realidade, monitorável pela observação dos cenários da vida. Nos detalhes de cada situação, no discurso do tempo e na dança dos elementos em combinações infinitas, aleatórias ou não, sínteses simbólicas distraídas formariam uma linguagem mãe, irmã e filha da poesia, que faria do tempo um laboratório de criação pessoal e coletivo, e dos acontecimentos da vida um improviso cósmico. A humanidade seria um coletivo artístico. É uma visão de mundo imensa e libertadora que nasce na leitura das memórias do dramaturgo. Ou pode ser o oposto, uma perspectiva infernal, incestuosa, pelo grau do prazer e do terror do excesso de consciência necessário para se processar tamanha linguagem. Abre também uma porta para a loucura, a prisão da psique no êxtase visionário.

A afirmação surge no penúltimo parágrafo do capítulo que lança a ideia de uma alquimia inerente ao fazer teatral. Se Fauzi fala da alquimia estudada por Jung como sistema de conhecimento baseado em imagens, seria a chave para uma possível linguagem do inconsciente, a própria realidade como léxico, baseado em algum sistema alquímico extraído da prática teatral. Em si, a própria ideia da simbologia de tudo se refere a algo muito além do verificável e do exprimível. A realidade como linguagem falaria do jogo de forças ativo na alma de cada observador, uma metáfora concreta, de trunfos imponderáveis, feita de imagens múltiplas de múltiplos pontos de vista. Algo parecido com a ferramenta do terapeuta quando desperta e acompanha o processo de diálogo do paciente com o próprio Inconsciente, tradicionalmente, através dos sonhos, mas no caso de Fauzi e Dr. Murilo, através de alucinações observáveis. Numa sessão de psicoterapia, essa interação se complementa na situação preparada e o acompanhamento das imagens psíquicas, que dá o sentido às dinâmicas em jogo. Além da linguagem verbal, há o tempo e o espaço separado, e o compartilhamento apurado do histórico do paciente e seu mundo imaginário, formando uma linguagem ampliada pelas condições do encontro. No contexto cotidiano, a cada momento, a cada curva, o mesmo tipo de informação estaria disponível à percepção inconsciente, mas nunca totalmente à percepção consciente. E a falta de referências normalmente impossibilitaria a compreensão do que se percebe além do trivial. Pelo depoimento, parece que Fauzi teve um caso de percepção sensorial extrema dessas camadas extra de realidade, num grau de compreensão agudo, de algo absolutamente fascinante, porém complexo e desconhecido. Por mais urgente que lhe parecesse compartilhar aquilo com todo mundo, era algo muito além de sua capacidade cognitiva. Essa impossibilidade seria o vácuo a ser preenchido por outra linguagem, muitas 
vezes resultando em arte. Pode ser alguma coisa universal, já que todos passam por isso em algum grau, ou um tipo de linguagem viral, alguma moda; ou pode ser uma solução única, particular, que brota espontaneamente de uma psique individual. Dessas, muitas se perdem nos vagalhões de incompreensão do coletivo programático, e há um jardim no Hades para os gênios de gaveta. Outras se encontram na obra de artistas como Fauzi, quando ele lança essa imagem, talvez como um encantamento, para levar ao entendimento alquímico de seu Elixir.

$\mathrm{Na}$ obra de Jung, a alquimia tradicional é estudada como um manancial imagético guardado no inconsciente humano, que mapeia o processo de evolução da psique. Um mapeamento dinâmico do metabolismo psíquico, feito de imagens simbólicas criadas por um processo de projeção psíquica dos alquimistas de todos os tempos em sua busca milenar pela transmutação dos metais. Uma grande e complexa metáfora para o processo de cura e evolução psíquica, criada pelo tempo, renascida como sistema de estudo da psique, decifrada por Jung como um jogo de símbolos mutáveis e particulares, ao mesmo tempo universais, capaz de falar de assuntos que não se completam na face técnica da palavra, nem no léxico de uma ciência complexa como a psicologia analítica. Em sua leitura do legado alquímico, essa ciência revela um caminho possível para uma alquimia da alma, sinônimo do processo da individuação, o trabalho voluntário pelo aprimoramento do ser no relacionamento entre o consciente e o inconsciente, entre o Ego e o Si-mesmo, a personalidade e a Totalidade viva no centro da alma, uma conquista do equilíbrio psíquico que torna um ser humano indivisível, um consigo mesmo e com o universo.

O que interessa numa abordagem dessa Alquimia ligada ao pensamento sobre o Teatro, ou sobre qualquer linguagem artística, é que nessa visão psicológica, a Alquimia tende a se fundir com a linguagem que ela produz, porque o material da psique também é essencialmente imagético.

O inconsciente é feito de imagens. Um exemplo fisiológico disso são os sonhos, que seriam essas imagens, ou o próprio Inconsciente, em seu caminho de dentro para fora. São a única forma de comunicação pura e direta do Inconsciente na direção da consciência. São fenômenos da natureza, imagens e fatos que acontecem por si em nossa mente. Nessa espontaneidade, revelam alturas sombrias e profundezas luminosas da alma. Além dos sonhos, outras imagens entram nessa categoria, incluindo as que vem à consciência numa sessão lisérgica, e todo tipo de oráculos e principalmente as "coincidências significativas", nome que 
Jung dá às sincronicidades, e que seriam pontos evidentes de uma chamada "realidade como linguagem". Segundo Jung, o processo de evolução psicológica se revela potencialmente alquímico através dessas imagens, que são, ao mesmo tempo, fatos psíquicos "e" linguagem.

Quando uma imagem $X$ vem à mente, isso é um acontecimento. Tem consequências na realidade. Como aconteceu no caso de Fauzi escolhendo a iconografia cristã para expressar sua identificação com o arquétipo do Sol Nascente. E como Fauzi usa na trama da peça Um Ponto de Luz: a personagem da mãe é perturbada por um sonho em que viu o filho morrendo. No plano concreto, nada aconteceu, foi um sonho. Mas depois, ela tem toda sua ação determinada por esse fato, que é unicamente uma imagem na cabeça dela. Em vez de um sonho, poderia ser uma coincidência, uma sincronicidade, uma ironia do destino. Um acontecimento psíquico, real porque tem decorrências no mundo concreto. Como estes acontecimentos psíquicos se formam é outra questão. Ou muitas questões. Em si, as imagens psíquicas não seriam ainda uma alquimia, mas sinais de uma dinâmica que envolve toda existência individual, algo que aconteceria por si, independentemente. E que pode ser transformado em Alquimia por uma ação intencional, uma operação habilidosa.

A ideia de uma "alquimia do teatro" conecta essa dinâmica ao fazer teatral, ao processo de criação de uma arte feita não apenas de imagens, mas de imagens vivas, respirando e se movendo em carne e osso no tempo e no espaço. Se a arte alcança o resultado de encarnar uma imagem do Inconsciente, quando se considera que estas imagens podem ser fatos psíquicos com decorrências concretas na realidade, se dimensiona o alcance dessa arte.

Essa investigação não resolve esta tarefa, inclusive porque é uma tarefa que provavelmente só se resolve em ensaio, na "batedura" da arte. Este estudo é uma dramaturgia em processo que se inspira na "dupla morte" dionisíaca e na transformação do raio divino em Cena, seguindo as pistas deixadas por Fauzi. Uma delas, o respeito por um campo de conhecimento essencialmente hermético, do qual ele só cita o nome, cita a fonte, relaciona alguns aspectos básicos e não toca mais no assunto, diretamente, mas lança a isca criativa que esse texto morde, temática e estrategicamente.

Uma dinâmica psico-imagética inerente à existência, aplicável no contexto do Teatro, análoga à aplicação dos símbolos alquímicos na interpretação e na operação dos processos psicológicos ou a aplicação dos mitos para identificar os arquétipos em jogo e organizar os conteúdos esquivos da psique, Fauzi vê o mesmo jogo de imagens camuflado por entre as 
dinâmicas do fazer teatral, com uma possibilidade de aplicação similar pela operação ativa da "alquimia inerente a arte da representação". Possibilidade, na maioria das vezes latente, ou inconsciente e errática. Ele mesmo se coloca como um aprendiz perdido, mas o depoimento dá a deixa para um acesso a essa arte, ou ao desenvolvimento da capacidade para essa operação habilidosa.

Para pegar essa deixa sutil, observamos o capítulo 20 o teatro da alquimia e a alquimia do teatro, entendendo este título como um enigma, já que o texto do capítulo não faz referências específicas à alquimia, mas narra o caso de uma coincidência significativa perturbadora durante a montagem da peça Um Ponto de Luz que estudamos no capítulo adiante. Os acontecimentos põe em xeque a tese conceitual do texto, revelando uma dinâmica de forças evidente, mesmo sem causalidade concreta. Para Fauzi, essas correspondências palpáveis mas não causais, entre os significados encenados e os eventos randômicos na vida de atores e encenadores - revelam possibilidades urgentes, transmutações necessárias, que seriam as deixas para a ação de um alquimista da cena.

O papel alquímico da arte e a potencialidade que encerra de autotransformação me parecem estar associados a sua própria essência (...) sucesso e fracasso deveriam ser medidos pelo resultado interior. Quando alguém se transforma com um trabalho, isso é que deveria ser considerado um sucesso, e quando continua idêntico a si mesmo, ainda que o aplauso seja total, o resultado pode ser inútil. (ARAP, 1998, p. 237) 


\section{Capítulo 2}

\section{CENA QUÍMICA}

O teatro, como a vida, é uma arte feita de pessoas de carne e osso, respiração e voz em ação no tempo e no espaço. Como a tinta na pintura, a palavra na poesia, sons e imagens em movimento no cinema, a matéria prima do teatro são pessoas inteiras. Vivas e presentes, com suas vozes, imagens, pensamentos e sentimentos transformados em significantes e significados para compor uma obra de arte. Uma obra que acontece num momento e num local definido, mas mesmo assim tende ao infinito. Porque não nasce no começo nem morre no final do espetáculo, mas desperta no processo de montagem e se perpetua na vida, que é sua substância. Como se a tinta tivesse vida própria antes e depois dos quadros, e, na ausência de olhares, tivesse outras experiências, levando consigo a vivência dos conteúdos veiculados na tela. No teatro, a tinta é o próprio artista. Feito da interação de forças anímicas em processo, vivas e presentes fisicamente no momento em que a obra vem a existir, o teatro é sempre mais do que a interpretação, reflexão, reação ou representação da vida: é a própria vida. No palco ou na sala de ensaio, a poesia da peça, a mensagem, a graça, o que diz a cena, no silêncio ou no verbo, vibra no sangue da própria substância que dá vida à obra: o elenco. Composto de seres humanos vivos e presentes fisicamente. O conteúdo subjetivo de uma cena teatral não é só exposto, mas é encarnado.

Toda arte gera reações e emana certa vibração, mas uma arte feita de significantes vivos e conscientes teria recursos para imantar seus significados com uma força vital capaz de gerar uma vibração especialmente viva. Se a força vital dos artistas compõem e anima a materialidade do teatro, ela se multiplica nos significados em jogo, tornando-os de alguma forma mais efetivos, mais vivos, faz com que também vivam no corpo e na alma do público e de todos que compõem o devir teatral em seus vários estágios. Por essa vitalidade imanente, os significados veiculados na prática teatral ganhariam vida própria, através da vida dos envolvidos, compondo eventos na realidade concreta, mais ou menos transformadores, com ou sem causalidade objetiva.

Uma imagem da cena como câmara de descompressão, dando condições para que conteúdos abstratos ganhem materialidade anímica, encarnando-se como ideia, nascendo 
assim para habitar o mundo dos fenômenos. Símbolos, significados, sentimentos, sensações, uma vez vividos em cena pelos atores, estão na vida, como seres ativos e autônomos, agindo na realidade concreta através do inconsciente de cada um.

$\mathrm{O}$ ator, autor e diretor francês Antonin Artaud (1896-1948) escreveu no ensaio $O$ Teatro Alquímico: "É preciso acreditar que o drama essencial, aquele que estava na base de todos os Grandes Mistérios, esposa o segundo momento da Criação, o da dificuldade e do Duplo, o da matéria e do adensamento da ideia. (ARTAUD, 2005. p. 52)

Esse adensamento da ideia se dá quando ela é vivida no corpo do ator, por onde adentra o plano da existência. O corpo dos envolvidos seria o primeiro receptáculo físico de todo o conteúdo imaginário, imagético, poético, político, simbólico ou não, veiculado na peça. Por já ter habitado uma alma humana pelo tempo de contato com a cena, o conteúdo abstrato deixaria de sê-lo, ganhando vida própria. Isso teria, ou não, efeitos palpáveis nas vidas dos envolvidos, por ação direta em seus inconscientes. Daí a responsabilidade de trabalhar estes conteúdos conscientemente, para comunicar consciência sobre o conteúdo, seja este qual for.

Não é incomum ouvir falar de "ressonâncias" entre símbolos encenados e a vida real dos envolvidos, entre palcos e coxias, essa ideia se confere em superstições, conjecturas, estudos e experiências pessoais de técnicas e elencos. Mas alguma coisa nesse tipo de percepção normalmente se prefere não compartilhar. Algo íntimo, difícil de explicar fazendo sentido. Algo que Jung chamou de "Sincronicidades", ou "coincidências significativas" 'no texto em que define a ideia dos acontecimentos ligados por relação de significado sem relação causal: "São "coisas de que as pessoas não falam, com medo de se exporem a um ridículo insensato.” (JUNG, 2000, p.10)

É plausível essa influência concreta não causal entre os conteúdos da cena e os fatos que cercam os envolvidos? É algum tipo de fenômeno? Quanto e como os conteúdos em cena podem agir na vida de seus agentes? Como podemos lidar com isso? É possível agir ativamente em relação a esse "fenômeno"? O fundo perdido dessas perguntas é terra fértil para as sementes de entendimento do que escapa ao olhar direto. Fauzi entra no assunto falando das "freqüentes coincidências (...) entre a vida real vivida por atores e as circunstâncias da ficção que encenavam no palco, e o paralelismo entre as duas" (ARAP, 1998, p. 72). Conta alguns casos, e se aprofunda no capítulo 20, contando a história do surto psicótico de um ator na semana anterior à estreia de sua segunda peça, Um Ponto de Luz 
(1977), com sua tese de fundo contra a psiquiatria tradicional. O autor e diretor se vê num impasse: diante de uma situação extrema e perigosa, manter a coerência ou agir contra a tese implicada na peça? Aceitar um tratamento invasivo ou tentar a cura psicológica? Buscar uma solução química ou uma solução alquímica? "Eu me sentia mergulhado num pesadelo, porque na peça em questão, ao fim da segunda parte, a questão de uma internação de um dos personagens era discutida, e todo o texto pretendia demonstrar o absurdo desse tipo de solução que a Psiquiatria tradicional adota normalmente" (ARAP, 1998 p. 207).

O diretor não se traiu, e agiu para evitar os "métodos tradicionais", no caso, medicação e internação. Mesmo relutante e pouco convicto, seguiu a percepção ou suspeita de que a cena tem sobre a vida mais efeitos do que se reconhece:

(...) era como se a realidade tivesse resolvido me dar uma lição, diante de minha pretensão de autor de endossar as teses da Antipsiquiatria com uma simples peça de teatro, em que eu manipulava personagens e situações para que tudo acontecesse como eu queria. Eu me sentia estranhamente responsável por toda aquela loucura. Tudo acontecia de forma análoga ao enredo da peça, e ainda tive o bom humor de dizer que confiava que ele chegaria ao terceiro ato, pois a peça felizmente terminava bem (ARAP, 1998, p. 209)

A situação acabou se resolvendo com um golpe de sorte, ou uma coincidência, talvez significativa:

\begin{abstract}
Muitos integrantes da classe teatral haviam se valido de uma médica homeopata, em seu processo de "convalescença" do movimento hippie, (...) Conseguimos falar com a médica (...) era a segunda vez que aquele ator fumara alguma coisa, e, na primeira vez, a reação também havia sido desastrosa, tanto que ele havia sumido de casa por dois dias. E quem o havia tratado, e curado, havia sido exatamente a mesma médica. (ARAP, 1998, p.).
\end{abstract}

A cumplicidade anterior entre o ator em surto e a médica ajudou no desenlace, ela conduziu o resgate da sanidade mental dele, sem drogas nem violência, a tempo de estrear normalmente. Prevaleceu o respeito à loucura alheia, promovendo a vitória de uma consciência, ao invés do contrário, que significaria a internação e medicação. Pelo depoimento, Fauzi liderou o processo, foi ele o alquimista do resgate.

A associação entre teatro e alquimia é uma longa história. Diz Artaud em seu Teatro Alquímico: "é preciso notar a estranha afeição que todos os livros dedicados à matéria alquímica professam pelo termo teatro" e ainda: "Entre o princípio do teatro e o da alquimia há uma misteriosa identidade de essência.” (ARTAUD, 2006, p. 49/50). Fauzi falava dessa 
"alquimia" inerente à prática teatral como um fenômeno vislumbrado, mas não decifrado, natural para alguns, oculto e inacessível para muitos, involuntário e errático para quem ativa o potencial sem saber o que faz, mas acessível aos que se dispõem e reúnem qualidades e condições necessárias para certo mergulho fundo no coração da arte.

No sentido da psicologia analítica, alquimia é uma ferramenta de conhecimento e um processo de ampliação da consciência e desenvolvimento da psique. No sentido histórico, é um fenômeno comum da antiguidade à idade média, da China à Espanha, do Egito à Escócia, com tradições análogas ligadas à manipulação dos metais e minerais. Velho e sábio, Mircea Eliade escreveu, sobre Ferreiros e Alquimistas:

(...) reivindicam uma experiência mágico-religiosa particular em suas relações com a substância; esta experiência é seu monopólio, e seu segredo se transmite mediante os ritos de iniciação dos ofícios; todos trabalham com uma matéria que têm ao mesmo tempo por viva e sagrada, e seus trabalhos vão encaminhados à transformação da Matéria, seu «aperfeiçoamento», sua «transmutação»." (ELIADE, 1978, p. 4)

No caso narrado por Fauzi, se houve, no surto e na cura do ator de Um Ponto de Luz, alguma "experiência mágico-religiosa em sua relação com a substância" como a reivindicada pelos alquimistas nas palavras de Eliade, não houve uma transmutação clara. Se o ator voltasse e fizesse o melhor papel da vida, seria o ouro, mas não foi isso. Foi um resgate. E numa situação daquela, nem é tão improvável a indicação de uma médica amiga dos amigos... Ou seja: tem alguma alquimia aí, mas onde?

Há uma analogia com a trajetória de Fauzi, que também preferiu respeitar a própria loucura quando levou a sério suas descobertas psicológicas e por isso conquistou a vitória da própria consciência. Se ele operava algum tipo de Alquimia, essa analogia faz parte. Eliade fala sobre as "relações" dos alquimistas "com a substância", e no caso do teatro, a substância não seria só o assunto da peça, ou as dinâmicas e conflitos de sujeitos e ideias, mas o próprio ser humano, que é a matéria de toda cena teatral acontecendo: o ator. Mas também a equipe. E, por extensão, a plateia e o mundo. Se Teatro é Alquimia, a "matéria viva e sagrada" a ser aperfeiçoada e transmutada é o ser humano.

Então a alquimia, no caso de Um Ponto de Luz teria acontecido com aquela equipe, cada um no seu prisma. Fauzi já não era ator há 12 anos, mas era o diretor e autor da peça, e a analogia simbólica entre o que acontecia, o incidente do ator surtado, com um dilema 
fundamental da consciência dele - sobre levar ou não a própria loucura à sério, valendo o destino da consciência - chama atenção para o enredo da peça.

Além da crítica aos abusos da psiquiatria, Um Pontos de Luz tem outros mistérios. Há um personagem oculto, o "caboclo" incorpóreo que fala pela voz da índia curandeira, o universo da Umbanda ocupando espaço perfeitamente normal na narrativa, com parte natural da sociedade. E isso tem força política. Não importa a fé específica, importa levar à cena, na verdade, a transcendência, a informação, real ou imaginária, tanto faz, de que o mundo concreto não é tudo na vida. Em segundo lugar, encenar a tradição que expressa o sincretismo brasileiro, a união das raças sacramentada. É escolha de um autor que sempre advogou "a recusa em se separar o individual do coletivo, o místico do político, por entender a experiência humana como algo que só se realiza organicamente, sem falsas divisões.” (LABAKI, 1998 apud ARAP, 1998, p.18) A peça conta a cura de um adolescente atormentado por um dom espiritual com o qual não sabe lidar, mais uma mãe devoradora obcecada por uma premonição de morte e um pai tosco industrial farmacêutico que trai a mãe com a irmã dela. Na trama, a sabedoria está na boca de uma preta velha, a babá, e uma índia, sua colega no terreiro de Umbanda, e da cunhada "que não era parente". Juntas, advogam uma transcendência naturalizada. A liberdade da alma.

Curioso eco rodrigueano na família do protagonista, o pivô da separação de seus pais sendo uma traição com uma cunhada, como na peça $A$ Serpente, de Nelson Rodrigues, reforçando uma estrutura de melodrama que acentua a dualidade das visões de mundo em cena. A peça ocupa espaço imaginário com o que está fora do controle, sob outras regências. Fala de "outras vidas" de "incorporações" com naturalidade, mas sem naturalismo, porque as práticas da personagem não retratam práticas normais da Umbanda. A cena é um tipo de tratamento espiritual peculiar com o uso de uma poção indígena que provoca visões e revelações. Talvez isso na época passasse por algo genérico ou misterioso, hoje é clara a referência à Ayahuasca, a bebida ritual indígena que já vinha se tornando conhecida, tanto que aparece no enredo de "A Última Peça" de Zé Vicente, como conta Mamberti. Nas cenas em que a índia médium curandeira atende seu paciente, o procedimento se repete: ela serve um chá, ele bebe e tem visões, narra as visões, e ambos refletem juntos. Sem dúvida, Fauzi conhecia a dinâmica: o procedimento é precisamente o descrito por ele no primeiro capítulo do Mare Nostrum contando a experiência psico terapêutica com LSD no começo dos anos 60: 
no consultório, ele tomava a substância, tinha visões e conversava com o terapeuta. É uma correspondência instigante entre cena e vida à luz da alquimia, dado o papel que o relato da experiência lisérgica tem no depoimento do Fauzi, como ponto de partida de toda reflexão sobre o teatro e sobre sua passagem pelo mundo. Se o encontro com o LSD é o incidente detonador da narrativa, e o capítulo nomeado o teatro da alquimia e a alquimia do teatro fala de uma peça em que a ação principal do protagonista é uma experiência cenicamente similar à que o autor vivia nesse encontro, isso pode ser altamente significativo. Sugere uma relação estrutural entre as trajetórias do autor e da personagem. E fortalece o significado simbólico da cena, bem além do pessoal, sobre a sabedoria ancestral que cura pelas mãos de uma menina indígena reconciliando a alma com a natureza.

É importante dimensionar a experiência de Fauzi quando se fala nesse dom que a mãe (a sociedade), renega. Em Um Ponto de Luz, seria o dom mediúnico do garoto, ou uma vocação religiosa, um compromisso com as entidades do terreiro da menina. E no paralelo com a trajetória de Fauzi, a mãe simboliza a sociedade, e o dom vai além do talento artístico, é justamente o grau extremo de sensibilidade e capacidade de ação real num nível bem alto de vibração psico-emocional. Que ele alcançou graças à uma mistura explosiva, filha do espírito do tempo, entre a própria natureza absolutamente sensível, carismática, mental e talentosa, o dom artístico mesmo, e sua terapia com a injeção literal de muitas miligramas de LSD puro na veia, de 2 em 2 semanas, durante um bom tempo.

$\mathrm{Na}$ peça, numa das sessões, o personagem tem uma visão libertadora, verbaliza imagens de dragões, que enfrenta e supera a mãe devoradora etc. A imagem age na cena, ele se liberta, depois se perde novamente, mas com ajuda das forças femininas libertárias, consegue superar as barreiras e assumir seu dom. Na verdade, compartilhando a responsabilidade, numa última fala da peça dirigida à plateia: "Agora é com vocês!”

Por um lado, é uma transferência de responsabilidade que inclui a plateia na vitória do personagem: todos têm o mesmo dom, e a alquimia do teatro seria transferir a conquista do personagem para a plateia. A experiência de presenciar o símbolo vivo em ação daria aos presentes acesso energético às vivências das personagens. Quanto mais vivo o símbolo, maior o poder de acesso. Seria essa a tal Alquimia do Teatro? 
Por outro lado, é dito "Agora é com vocês" e não "agora é com todo mundo" ou algo assim. Talvez um sinal de que, mesmo depois de tudo, já duplamente renascido, Fauzi ainda se sentia isolado.

O menino da peça não é doente, só tem uma sensibilidade extrema que causou dificuldades, levando a mãe paranóica a enquadrá-lo, com ajuda do médico amigo da família, sócio do ex-marido farmacêutico, o homem-tarja-preta. A situação simboliza um sistema profundamente violento, naturalizado como familiar. A sombra da indústria farmacêutica é uma metáfora para a hipocrisia mais cruel. Fauzi nunca tomou remédios psiquiátricos além do Delysid LSD25. Mas hoje, talvez dissessem que ele precisava. Houve um momento da trajetória em que Fauzi foi como o personagem oprimido por uma mãe que via seu dom como doença. Quando ele colhia as flores de Perséfone a bordo da psicoterapia lisérgica e na volta tentava compartilhar, via seu entusiasmo maravilhado taxado de loucura ou debilidade mental. Nesse momento, ele também duvidou de si mesmo. Quando achou que as pessoas tinham razão, procurou um analista, o "mais careta possível” que só deixava ele falar sobre coisas produtivas e objetivas e ignorava quando ele entrava nas viagens abstratas, com ou sem LSD. $\mathrm{Na}$ dúvida, foi se acostumando, tentando se enquadrar, e teria vestido a camisa-de-força do preconceito, "um passaporte de volta à normalidade" : "eu acabava introjetando mais e mais aquele veneno, e, assim, quanto mais eu voltava a sua presença, mais me vinha a ideia de que eu realmente estava ou estivera louco, ou quase louco." (ARAP, 1998, p. 90)

Na peça, o personagem toma o chá numa sessão com a índia curandeira, e no efeito, se liberta dos dragões internos e conquista uma vitória. Mas depois, no processo, confunde as coisas, se apaixona pela Índia, agride a mãe, solta os cachorros sem noção. A mãe expulsa a índia e chama o médico da família, sócio do pai farmacêutico, que medica o garoto. Controlado, ele fica como Fauzi naquele momento em que ia vestindo a camisa de força do preconceito contra si mesmo para ter um passaporte da realidade. Na peça, isso dura alguns dias. A Índia quer consertar o estrago e concluir o tratamento, a babá insiste com a mãe, que acaba deixando. A índia faz a última sessão com o menino, a última cena da peça. E o que ele diz poderiam ser falas de um personagem baseado no Fauzi que se revela no Mare Nostrum:

CAO: Eu vejo sinais e símbolos, e tudo é um símbolo e tudo um sinal e tudo fala comigo. Eu tenho medo de falar qualquer coisa porque as palavras desarrumam tudo e sobram porque tudo fala sem falar. Eu nunca vou conseguir viver a vida do jeito que é, a vida do jeito de todos. (Um Ponto de Luz 2.28.111) 
Vinte anos depois, no livro depoimento, Fauzi fala novamente dos símbolos, não como constatação perturbadora, mas como conclusão firmada:

Não há nada de mágico nos episódios surpreendentes que o homem pode viver,
quando acontece de escapar casualmente de seu cotidiano mais mecânico e de se
deparar com estados alterados de consciência, que a Parapsicologia estuda. Todos
trazemos em nos essas potencialidades, se nos despimos dos hábitos que formam
nossa capa mais superficial e nossa identidade aparente. Tudo o que nos cerca é
simbólico. Trata-se de aprender a ler" (ARAP, 1998, p.238),

A segunda frase da fala da personagem Cao (nome que se equilibra entre o cão e o caos), sobre o "medo de falar qualquer coisa porque as palavras desarrumam" e "tudo fala sem falar", reflete o grande desafio interno que Fauzi encarou na crise detonada pela terapia. A incomunicabilidade, o abismos entre palavras e compreensão, o medo de falar ou a opção pelo silêncio também aparecem na peça anterior, Pano de Boca, na personagem do Pedro, um ator que se tranca no silêncio e se comunica por jogos teatrais, depois finaliza a peça como uma Esfinge ganhando voz: "Tu próprio és o objeto de tua busca: a voz sem falha, que ressoa através de eternidades, isenta de mudança, isenta de pecado, os sete sons em um - a voz... a voz... do silêncio. OM TAT SAT” (BLAVATSKY, apud, Pano de Boca, 2,112)

OM TAT SAT é um mantra em sânscrito, versículo 17.23 do Bhagavad Gita, significa "Om é Verdade, Om é Realidade, Om é Bondade", nome triplo para do conceito metafísico do Brahman, o mais alto Princípio Universal, a Realidade Suprema no Universo, ao mesmo tempo associado à alma humana. E análogo à ideia do Inconsciente, do Jung, que também presume a Totalidade presente no interior da psique. No tempo do Pano de Boca, Fauzi já tinha conquistado o verbo e percebido a mídia certa para falar sobre seus "sonhos, viagens e outros caminhos". Talvez tenha descoberto que "a voz sem falhas" a que se refere a Esfinge esteja, para os artistas do teatro, acessível justamente através de sua arte. No tempo da crise detonada pela terapia, isso não vinha tão claro. Era o invisível, o universo, a totalidade, a eternidade, a realidade suprema... A escala de Fauzi é abrangente. O que talvez justifique a terceira frase da fala de Cao: "Eu nunca vou conseguir viver a vida do jeito que é, a vida do jeito de todos."

Na sequência da cena final de Um Ponto de Luz, a índia curandeira dialoga com o garoto descrevendo visões cada vez mais extáticas, ao ponto em que ele quase celebra a própria dissolução total no éter, quando um "anjo" o impede de sumir no vento:

TANHÃ: (...) Teu lugar é aqui, por enquanto. 
CAO: Você está brincando? Não é não! Aqui eu sou um peixe fora d'água, aqui eu não tenho lugar, não tenho! Porque ele não me leva de vez?

TANHÃ: Você tem muito trabalho pela frente, Cao. Os outros precisam de você.

CAO: Quem precisa de mim? Aqui é tudo fechado e difícil, e você é a a única que compreende, a única. Mas você não quer ficar comigo.

(Um Ponto de Luz 2.28.113)

$\mathrm{Na}$ analogia entre o personagem no processo com o chá e Fauzi no processo com o Delysid LSD25, essa última fala tem ressonância com o rompimento entre Fauzi e o médico, Dr. Murilo Pereira Gomes, com quem teve uma relação profunda, de cumplicidade e admiração, que não terminou bem:

(...) depois de todo um início arrasador, minhas últimas sessões com Murilo aconteceram num clima de desconfiança recíproca (...) comecei a não confiar e a não me abrir mais com Murilo, os conselhos de minha amiga funcionando como álibi para que eu não mexesse em possíveis feridas mais profundas, não recebi mais prêmios nem passagens para o paraíso (...) Passei a desejar ser o sujeito que era antes, sem saber o quanto estava irremediavelmente comprometido com um novo futuro (...) acabei me perdendo do paraíso, sem ao menos conseguir regressar para a terra firme.” (ARAP, 1998, p.57)

O depoimento dá a impressão de que o fim do tratamento terapêutico com Dr. Murilo doeu como o final de um relacionamento afetivo. Remete à primeira libertação do personagem Cao, quando ele se confunde, se apaixona pela índia, e, ferido pela rejeição, abre a metralhadora giratória, fala o que deve e um pouco mais, assedia sua curadora, grita com a mãe, põe tudo a perder. A cena talvez reflita como ele se sentia nos momentos em que achou que falou demais ou deu vexame quando o processo começou a desandar. Como no dia de sua última sessão com Dr. Murilo, no caminho de volta pra casa, teve uma bad trip:

(...) o LSD fazia com que eu vivesse tudo aquilo como um pesadelo perigoso, porque eu me sentia bombardeado pelas energias circundantes, não muito harmoniosas, dos transeuntes (...) Em meu desespero, quando me descobri na porta do antigo Teatro Nacional de Comédia, não hesitei em entrar (...) sentado na última fila, cochilei o tempo todo (...) esse tipo de incidente acabou colaborando para que aumentassem os boatos sobre os malefícios do LSD e sobre quanto eu estava fora de mim. E tudo isso não me era evidente, obcecado que estava em apenas recuperar o estado iluminado que eu conhecera por breves dias. (ARAP, 1998, p,)

Ao mesmo tempo em que a personagem da índia de Um Ponto de Luz simboliza o terapeuta, ela também compõe o símbolo das forças femininas libertárias da peça, junto à babá e à tia, o trio que promove a retomada do processo da índia para ajudar Cao a domar seu dom. Isso talvez simbolize o quanto, para Fauzi, o processo de autoconhecimento e trabalho evolutivo que foi ativado na terapia não se interrompe com a saída de cena de seu primeiro "mestre", Dr. Murilo. Uma vez iniciado, o processo independeria do terapeuta. Mas conta 
com a ajuda da sabedoria ancestral simbolizada na figura da preta velha e da índia, e também da verve libertária da irmã-tia-cunhada, mais ética do que moral.

Na vida de Fauzi, a influência das forças libertárias femininas é determinante: parceiro de Clarice Lispector, Nise da Silveira, Maria Bethânia, Tônia Carrero, Maria Alice Vergueiro. Na comparação da trajetória de Fauzi com a do jovem personagem da peça Um Ponto de Luz, essa influência redentora da arte e da parceria de Clarice na obra do dramaturgo tem sua possível ressonância simbólica na imagem do trio que aparece para ajudá-lo a domar seu dom, a babá Luna, a índia curandeira Tanhã e a tia desajustada Alegria. Em outras palavras, ou em outras imagens, as três representem a sabedoria ancestral e a ousadia libertária análoga àquela que tocou a alma de Fauzi no trabalho de Clarice. Na cena final, a última sessão do chá do menino com a índia, no transe final, aquele que resolve a questão, o menino se torna um homem conectado com sua voz interior:

A voz... Eu estou ouvindo uma voz dentro de mim. Luna, eu não estou ouvindo,
existe! (ouve por segundos.) Eu não estou sozinho, nunca estive! Essa mesma voz,
sempre, e eu chamava de silêncio, de pensamento, intuição. Por trás do silêncio
existe uma voz, uma força que sabe e guia. E todos tem, todo mundo tem, mesmo
sem saber.
(Um Ponto de Luz 2.28.115)

Mais uma vez o silêncio, mas agora a voz do silêncio. No vocabulário da psicologia analítica, "a voz" é normalmente uma referência a um contato direto com o Inconsciente. Quando se ouve "uma voz" no sonho, seria um conselho do Espírito à Alma (ou do Inconsciente à Psique), uma comunicação direta do Inconsciente, esta entidade psíquica que, segundo Jung, é uma porção particular da Totalidade Absoluta viva dentro da psique humana; Totalidade que não deixa de ser Totalidade por ser porção individual, por isso se configura como um Deus interior. Donde estar ouvindo a voz dentro de si significaria, no caso, estar em conexão direta com seu próprio Deus. Nada mal para uma personagem que começou a peça como um doentio sufocado pela mamãe.

Essa forte analogia da trajetória de Fauzi com o caminho do personagem Cao de Um Ponto de Luz reforça o quanto a peça bota em cena infinitamente mais do que a história daquelas personagens fictícias. De certa forma, Fauzi retrata, inconscientemente ou não, uma afirmação de suas conquistas psicológicas, dele mesmo "domando seu dom”. Provavelmente outros membros da equipe teriam suas próprias alquimias em curso, e compartilhando estas conquistas e este "dom" com o público, com a última fala de Cao: "Agora é com vocês". 
Com tantas analogias simbólicas entre as histórias contadas na cena e a vida do autor diretor, analogias total ou parcialmente inconscientes - não se pode saber - é possível imaginar, numa lógica não linear, que o incidente do ator que surtou antes da estreia de Ponto de Luz escondia um dilema ético vital para Fauzi, capaz de uma interferência quântica atemporal em sua trajetória: se ele não agisse para evitar a medicação e internação do ator, ou se desistisse de ter aquele ator no papel na estreia, e com isso lhe negasse a vitória da sua consciência, em algum momento, antes ou depois - porque o desafio sempre volta - ele mesmo teria se traído. Quando beijou a lona no vácuo de sua epifania, teria pedido socorro químico para cortar sua conexão com o infinito, que já não estaria aguentando mais. Não teria conseguido a vitória da própria consciência. E nada jamais seria como foi, nem antes nem depois.

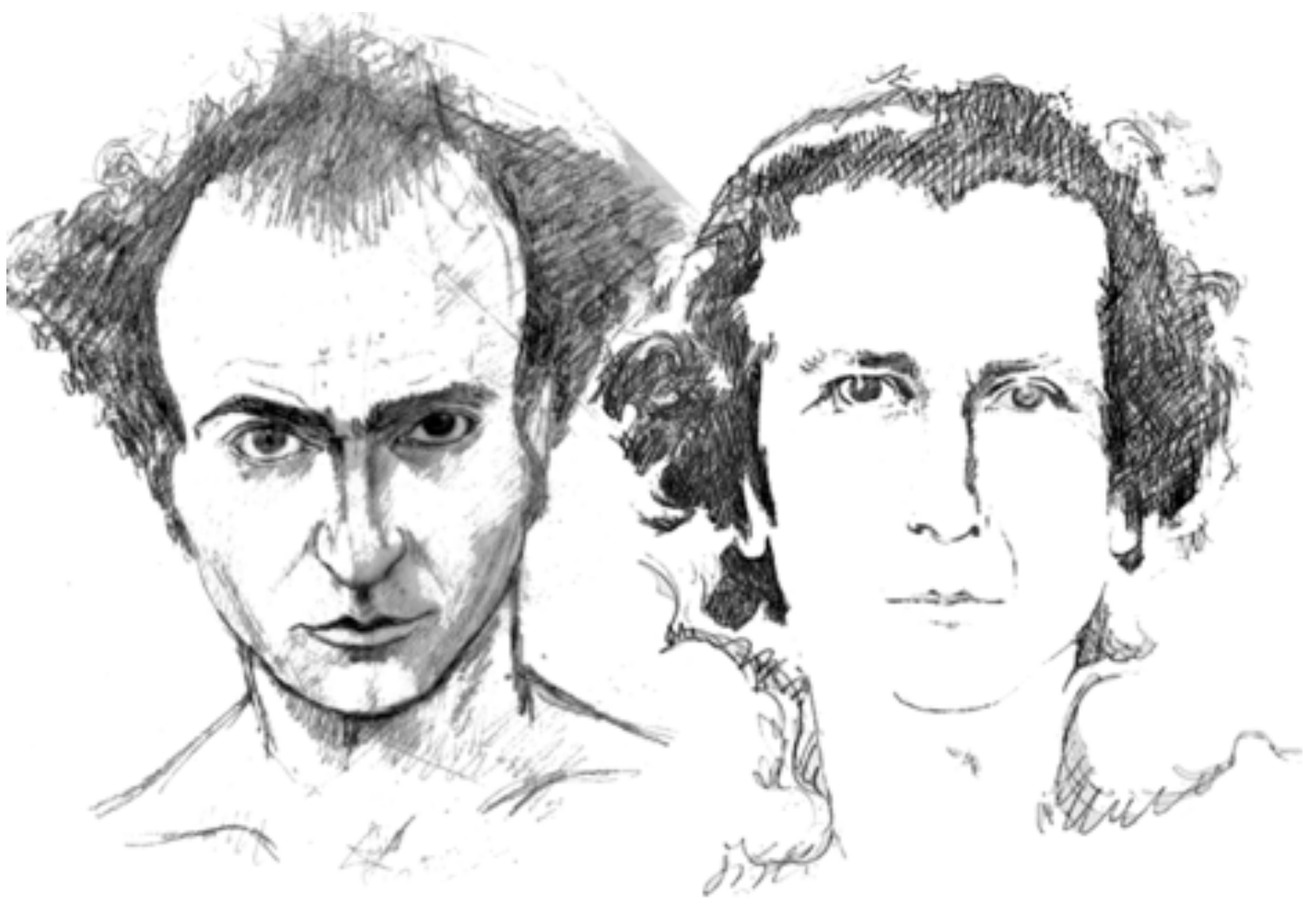

Auto retrato de Flávio Império e desenho de Fauzi Arap por Império.

O retrato do diretor está no programa do espetáculo Um Ponto de Luz, de 1977. Acervo Flávio Império. 


\section{Capítulo 3}

\section{OFICINA ALQUÍMICA}

No curso desta investigação, por uma sincronicidade feliz, no segundo semestre de 2016 acontece o "Simpósio Teatro Oficina: Seis décadas de cena radical brasileira", e um dos encontros iniciais foi uma roda de depoimentos de atores e atrizes de diferentes épocas do coletivo. Durante a reunião, palavras e ideias trazidas pelos artistas chamam atenção, remetendo, inevitavelmente, ao depoimento de Fauzi, que também foi ator no Oficina. Os dois tempos dialogam: no Simpósio, os artistas falam sobre sua experiência no teatro tocando em pontos chaves do Mare Nostrum. De um lado, o começo dos anos 60, primeiro momento do Oficina, um ator de presença marcante no núcleo original do grupo, ainda isolado num ambiente cultural fortemente influenciado pelo marxismo e a psicanálise, já intuía, ainda que cuidadosamente, o teatro como um processo alquímico "inerente à arte da representação" (ARAP, 1998, p. 211). Hoje, o elenco do Teatro Oficina parece muito mais à vontade com ideias similares. Camila Mota fala em "vodu", "técnicas de transe", "telepatia"; Lucia Helena Gayoto em "técnica espiritual” e "métodos sagrados"; Roderick Himeros em "transmutação"; Sylvia Prado em "questão ritual" e "alquimia". Ao final da reunião, a diretora e iluminadora Cibele Forjaz comenta as falas dos participantes definindo Zé Celso como um "diretor alquímico". E essas ideias e conceitos soam mais ou menos familiares para a maioria dos presentes, embora ainda possam parecer simplesmente exóticos para boa parte da população.

Inevitável a nostalgia de uma conversa impossível entre estes artistas, em 2016, e Fauzi, também um ator do Oficina. No programa do espetáculo José, do Parto à Sepultura, de Augusto Boal ${ }^{41}$, com direção de Antônio Abujamra, no Teatro Oficina, em 1961, Fauzi aparece como uma espécie de D’Artagnan do grupo. Diz o texto: “fauzi arap pra nós do oficina é mais um personagem... quando a gente diz ele não gosta... mas tal a identidade com os tipos que representa que deixa de existir ator desde os ensaios". (2)

\footnotetext{
${ }^{41}$ Augusto Pinto Boal (1931 / 2009) foi diretor de teatro, dramaturgo e ensaísta brasileiro e uma das grandes figuras do teatro contemporâneo internacional. Fundador do Teatro do Oprimido, técnicas e práticas que alia o teatro à ação social e se difundiu largamente pelo mundo, usado como instrumento de emancipação política e nas áreas de educação, saúde mental e no sistema prisional. Autor de 22 livros publicados e traduzidos em mais de vinte línguas, suas concepções são estudadas nas principais escolas de teatro do mundo.
} 
De fato, Fauzi deixou a carreira de ator e virou diretor e autor de outros projetos, mas os frutos desse contato vão além das primeiras montagens que firmaram o Oficina na cena nacional. A visão cultivada por Fauzi em sua prática e em seu depoimento, de um teatro vivido como caminho alquímico, no sentido psicológico, reverbera entre os colegas de Oficina presentes no simpósio em 2016.

A dimensão das obras destes artistas - Zé Celso, Augusto Boal, Renato Borghi ${ }^{42}$, Maria Alice Vergueiro e outros parceiros dos primórdios dos grupos Arena e Oficina, grupos irmãos com os quais Fauzi colaborou em igual medida - faz imaginar o nível dessa colaboração, o entusiasmo da idade e do tempo, a força das conversas nos ensaios entre cérebros brilhantes, cultos e com escolhas intelectuais libertárias. E num mundo às vésperas de uma revolução comportamental definitiva, na qual eles estavam na linha de frente. Depois de compartilharem criações poderosas, ainda cedo na história do Oficina, Fauzi segue caminho independente. Talvez nem tudo fosse flores entre ele e Zé Celso. Sobre sua participação na montagem de Pequenos Burgueses, o ator escreveu: "Eu não tinha, por parte do grupo, nem do diretor José Celso, nenhum retorno positivo do meu trabalho, e essa falta de confirmação interna me deixava desorientado.” (ARAP 1998, p. 65). Lembrando que, naquele momento, ele vivia a tal fase de "angústia permanente" e isso não devia facilitar nada pra ninguém. Ou talvez tenha sido realmente intensa demais a liberdade que os dois alcançaram juntos, em processos que já continham, como na semente de uma grande árvore, toda potência que se confirma 60 anos depois. Talvez tenham vislumbrado juntos a dimensão do teatro como "Grande Arte", possivelmente já na profundidade que hoje reconhecemos tacitamente e que ambos levaram décadas para dar conta. Ao que tudo indica, era um poder que precisava ser multiplicado.

Movido por sua combinação entre erudição intelectual e uso terapêutico do LSD, Fauzi desenvolveu sua perspectiva e seu modo de fazer teatro. E, ao que tudo indica, em seu momento germinal, essa perspectiva foi compartilhada com seus companheiros de jornada, e entrou na composição do que hoje se manifesta na potência do Teatro Oficina e sua Tragicomédiaorgia Antropofágica.

\footnotetext{
42 Renato Borghi (Rio de Janeiro, 1937) ator e autor, um dos principais integrantes da primeira fase do Teatro Oficina. Estreia profissionalmente em 1958, no Rio de Janeiro, na montagem de Chá e Simpatia, de Robert Anderson, direção de Sergio Cardoso. Em 1959, atua em A Incubadeira, primeira peça de José Celso Martinez Corrêa, logo a seguir, de A Engrenagem, de Jean-Paul Sartre, direção de Zé Celso e Augusto Boal. Em 1961, tornase sócio do Teatro Oficina. Depois de A Vida Impressa em Dólar, de Clifford Odetts, em 1961, torna-se aluno de Eugênio Kusnet, ator e autor do livro “Ator e Método". Em 1967, vence os prêmios Molière e Associação Paulista de Críticos Teatrais - APCT, pelo papel do usurário Abelardo I de O Rei da Vela, de Oswald de Andrade (1890 / 1954). Atua intensamente na Televisão, no Cinema e no Teatro, diversas vezes premiado.
} 
O estudo científico da trajetória das idéias, influências, inspirações mútuas e múltiplas que formam a alma de um coletivo como o Oficina é um manancial para divagações poéticas. Em que medida o pioneirismo de Fauzi no contato com conceitos como transcendência e expansão da consciência, ainda num ambiente cultural incompatível, contribui para a construção de um discurso ou de uma espécie de paradigma do Oficina, é algo a ser averiguado como um exercício poético de revelação dessa conversa impossível.

Felizmente, não existe conversa impossível no plano das ideias. Se as experiências vividas por Fauzi no início dos anos 1960 tem algo a ver com o atual ambiente intelectual e simbólico do Oficina, ou não, este exercício de investigação é sobre uma possível cultura método, sistema de pensamento, ou que seja vaga mentalidade por trás do discurso compartilhado nos depoimentos daquele encontro no Simpósio, ligados, de alguma forma, a um conceito de teatro como prática "alquímica", lato sento. Por isso resolvemos criar essa "conversa" à partir de entrevistas individuais com atores e atrizes de presença marcante na trajetória do Oficina, tratando, editando e costurando as observações inspiradas pelo pensamento de Fauzi.

Aqui, a palavra "alquimia" é usada no sentido amplo, sem analogias específicas com processos alquímicos tradicionais, mas com a ideia vaga de uma transformação redentora num contexto simbólico e transcendental. Fauzi fala de como teve que lidar com efeitos colaterais dos símbolos manipulados na matéria teatral, inferindo o poder intangível da arte da encenação influir decisivamente na vida dos envolvidos com a cena, em maior ou menor grau:

\footnotetext{
"pude constatar de que forma a sincronicidade entre os fatos relatados e os bastidores do espetáculo se confundiam perigosamente. Acabei me descobrindo quase um aprendiz de feiticeiro que, mesmo conhecendo alguma coisa sobre esse terreno perigoso, acabava metendo os pés pelas mãos na administração do que não pretendera provocar." (ARAP, 1998, p. 226)
}

Inspirada na liberdade mental impressa no texto de Fauzi, esta investigação estabelece gatilhos, mas se alimenta da possibilidade de atingir alvos inusitados. Que seja o simples registro das reflexões dos artistas sobre o teatro e a vida, num encadeamento de ideias que honre a expressão dos artistas estudados e possibilite, humildemente, a transgressão de uma conversa impossível.

Os artistas que generosamente compartilham suas reflexões são Luciana Domschke, Marcelo Drummond, Pascoal da Conceição e Camila Mota. Um grupo certamente 
significativo, embora gostaríamos de trazer as palavras de vários outros igualmente significativos, mas a própria conversa vem ensinando: é o que é.

\section{AMOR AO QUE ACONTECE}

A primeira entrevista foi com a atriz e cirurgiã Luciana Domschke, em 01/11/2016. Luciana entrou no coletivo em 1982 saindo da EAD, e por 5 anos foi parceira visceral no período subterrâneo do Oficina. Depois deixou o teatro para tornar-se médica cirurgiã, e no ano 2000 voltou para o Oficina por mais 7 anos e uma monumental participação na saga "Os Sertões". Antes de entrarmos nas perguntas, comentei minha impressão, a partir de sua fala no simpósio, de que sua experiência no grupo foi marcada por um posicionamento firme de sua individualidade em relação a um coletivo forte que, pela minha observação de público, tende a se impor sobre os indivíduos.

LUCIANA DOMSCHKE: “A individualidade, não sei se foi totalmente preservada. Acho que houve muita mistura, muita troca, muito desvio. Mas, na essência, na origem da minha motivação, realmente o que aconteceu é que... Quando você tem amor ao que acontece, na hora, ou mais pra diante, não importa, você consegue reter aquilo que ressoa ao que é bom. Considerando que é bom o que traz leveza, uma certa tranquilidade."

Nas primeiras frases da primeira entrevista registrada para este estudo, a atriz fala em "amor ao que acontece" - palavras que praticamente invocam para a cena o pensamento trágico de Friedrich Nietzche, filósofo que se declara "um aprendiz de Dioniso", deus personagem da peça mais marcante do Teatro Oficina.

Segundo o autor, pesquisador e professor Luiz Fernando Ramos, em palestra sobre a dramaturgia do Ofícina no Simpósio, em 10 de Novembro de 2016, a "peça dominante" do repertório do Oficina é a tragicomédia-orgia "Bacantes", protagonizada pelo deus Dioniso. No mesmo encontro, a diretora e iluminadora Cibele Forjaz também reforçou que "Bacantes" é "uma peça que perpassa as outras".

É sincrônico que a atriz, mãe de papéis cruciais do coletivo, abra o diálogo evocando uma das ideias chave do pensamento trágico: "amor fati", do latim "amor ao destino", ou, exatamente, "amor ao que acontece". A expressão é definida no tratado autobiográfico do autor de "Ecce Homo" como a "fórmula para a grandeza no homem": "Amor fati: nada 
querer diferente, seja para trás, seja para a frente, seja em toda eternidade. Não apenas suportar o necessário, menos ainda ocultá-lo - todo idealismo é mendacidade ante o necessário - mas amá-lo.” (NIETZSCHE, 1974, p. 382) As palavras da atriz são precisas e não vem do contato intelectual com o pensamento trágico:

LUCIANA DOMSCHKE: “a gente é tão propenso a criar mitos e ídolos, e isso não é favorável para que a vida aconteça individualmente. (...) não acho que o que a cultura existe para propiciar a vida, justamente acho o contrário, que as culturas todas são sustentadas por uma outra regência, que não favorece a vida."

Amar o que acontece, mesmo que não favoreça a vida. E talvez encontrar a beleza deste paradoxo. Não o bem, a verdade ou a justiça, mas a beleza. E vivê-la conscientemente. $\mathrm{Na}$ vida, ou na redenção poética da cena. Seria este o sentido do pensamento trágico? Seria esse o sentido da experiência da atriz no teatro Oficina?

LUCIANA DOMSCHKE: "a gente, como ser humano vivo da natureza, se impactando por essas aglomerações sociais em diversas culturas através dos tempos, é um pouco como se fosse "passar pelo Oficina". É como se fosse um microcosmos, a passagem pelo Oficina, é também passar por uma existência em qualquer lugar e em qualquer tempo. A luta é a mesma."

A imagem sugere a potência da experiência da entrega à "batedura" do Teatro, o nível de entrega necessário, talvez ideal, para se "fazer teatro" como se deve, sendo num coletivo como o Oficina ou não. Mas que luta é esta?

LUCIANA DOMSCHKE: "Não desistir da sua vida. Não esperar que venha da estrutura onde você está, seja o Oficina, seja a Grécia ou seja a China ou a Índia. Não vai vir de lá. O caminho é o que flui com leveza. Algo que vem de dentro. E que tem que vir de outro lugar, porque dentro, tudo é tão imperfeito. Tem que vir de algum lugar para dentro, pra depois sair. E esse lugar não é o Oficina, ou os gregos. Não é essa a fonte."

Existe um exercício budista que propõe o contato com essa fonte anterior através de uma busca objetiva da origem de qualquer experiência subjetiva. A ideia é procurar de onde vem qualquer fluxo de pensamento, emoção ou sensação forte, voltando a atenção, ou olhar interno, para o "local" de onde brota este fluxo. Quando se percebe que não há nada definível por trás do pensamento, emoção ou sensação. As raízes destas manifestações estão cravadas no nada. Um "nada" que também se experimenta como um "tudo" indefinível. Talvez análogo ao que a mitologia grega chama de Caos primordial, origem atemporal de todas as coisas, idéias, emoções, sensações ou fatos, que passam a existir à partir do próprio movimento que define sua manifestação. $\mathrm{O}$ curioso é que um campo anterior à manifestação implica em sua extinção imediata no instante em que algo passa a existir. A origem das coisas é sempre a 
morte da pureza original. Morte e vida renascem juntas em moto perpétuo, irmãs gêmeas paridas a cada respiração do tempo espaço. Talvez essa consciência da realidade seja a verdadeira individualidade, ou a única possibilidade de uma individualidade plena integrada ao coletivo.

Na mitologia grega, é a deusa Héstia a guardiã da lareira e do centro da casa, a virgem do Olimpo, quieta, discreta e sem história: ela só está lá.

LUCIANA DOMSCHKE: "No ensaio de Sertões, eu fiquei 6 horas na mesma posição, deitada. Foi como eu formei a personagem Terra. (...) [Como] um fio terra pra o que acontecia, de maneira bastante caótica, em torno de mim. Parada, deitada e sentindo o movimento das pessoas, dos atores, ouvindo a música, percebendo a dinâmica e o pulsar daquele laboratório (...) eu era uma prancha de terra, uma pedra, algo mineral mesmo, e minha ação estava numa camada mais etérea, num plano que não se vê (...) reverberando em outras camadas não físicas, mas totalmente presente de corpo físico, em contato com tudo também fisicamente. Porque o teatro sem o físico é inconcebível."

Mas Luciana não se entusiasma com a expressão "alquimia do teatro".

LUCIANA DOMSCHKE: "Não tem a ver com Alquimia, tem a ver com relação humana, com você enxergar o outro. Ter empatia. Perceber que se pode trocar. Não é "mágica", é uma coisa muito humana, tão humana, que a gente acaba querendo ser menos humano. Não é o teatro que é alquímico, a própria existência, a coisa viva, ela tem em si essa qualidade de ir se refazendo a todo minuto. Inclusive porque precisa. Porque, nesse momento, em nossos corpos, aqui e agora, tem células sendo mal produzidas, e tem outras células detectando isso e, através do sistema imune, ou provocando a morte, ou as próprias células se suicidam e vão pra um sistema de reciclagem, e novas células vão sendo produzidas. E isso é constante.”

Novamente Nietzsche: "O mundo subsiste; não é nada que vem a ser, nada que perece.

Ou antes: vem a ser, perece, mas nunca começou a vir a ser e nunca cessou de perecer conserva-se em ambos... Vive de si próprio: seus excrementos são seu alimento." (NIETZSCHE, 1974, pag. 260)

LUCIANA DOMSCHKE: "A medicina não me deu segurança pra eu me considerar apta a interferir na vida das pessoas, eu fui procurar no teatro o que eu queria aprender sobre como as coisas funcionam e como fazer que funcionem mais ligadas à natureza. Eu vi no Teatro essa possibilidade, ali, no meio do centro de SP, no meio de tantos prédios e tudo, um espaço reservado pra Terra, pra Água, um projeto que previa uma abertura de um teto pra se ver o Céu, Lua, estrelas, isso que me interessou muito."

Luciana não adere à ideia da alquimia como sistema, mas mostra afinidade quase distraída com os elementos e as linhas mestras que aproximam a prática teatral de um pensamento "alquímico". O paradoxo é um ótimo sinal. 


\section{TEATRO COMO CAMINHO}

Fauzi fala no teatro como um "caminho de alquimia e transformação", e Luciana, a seu modo, compartilha da perspectiva:

LUCIANA DOMSCHKE: "Sim, o teatro é um caminho. Um caminho de desvendar as suas ações e a das pessoas, maneiras de se relacionar. É um caminho e acaba te levando para alguma coisa que, eventualmente, não é o teatro. Uma espécie de laboratório, um território livre, preparado, um terreiro onde é isso que se faz como fim: adquirir ferramentas e instrumentos pra caminhar em qualquer área e em qualquer profissão."

O teatro como caminho para formação pessoal, como forma de auto-aparelhamento. Sem dúvida é algo comum a toda arte, ou toda habilidade vivenciada também como processo de aprimoramento pessoal. Mas Fauzi vai além, fala do teatro como caminho num contexto de polarização metafórica entre Luz e ausência de Luz.

$\mathrm{O}$ comum dos mortais costuma atribuir ao isolamento e à morte uma cor escura, ou a ausência de Luz, mas talvez seja essa mesma coisa tão escura, sem que saibamos, que nos conduza, e seja ela mesma nosso guia em nossa procura incansável de uma possível luz absoluta. E o teatro foi um caminho. O teatro é o caminho, por onde se pode e se deve passar, e nunca ficar. (ARAP, 1998, p. 226)

Fauzi declara sua visão do teatro como sendo não apenas um caminho, mas "o caminho", essencialmente dinâmico, e parece assumir que a "procura incansável de uma possível luz absoluta" não é apenas sua, mas de todos. Uma concepcão teleológica da vida que parece um tanto contraditória em relação a suspeita de que talvez seja justamente a "ausência de Luz" a verdadeira fonte de orientação para quem busca seguir "o caminho" em direção à Luz. Entender o que ilumina o caminho para a Luz como sendo justamente a ausência de Luz é trazer para cena o paradoxo alquímico do "Ouroboros" - do grego antigo: oủpá (oura) que significa "cauda" e ßópos (boros), que significa "devora" - a serpente que devora a própria cauda, simbolizando a eternidade.

LUCIANA DOMSCHKE: “(...) quando a gente tem uma convicção, pela Luz, por exemplo, faz parte se abrir para as coisas com um discernimento do que pesa e do que não pesa (...) [mas] não cabe preconceito, não precisa negar as coisas que se encontra pela vida e que nem sempre são claras, são sombrias também."

O discernimento é normalmente ligado a valores comuns, mas não necessariamente. $\mathrm{O}$ certo e o errado são postos à prova quando o desejo da alma se contrapõe aos códigos morais ou similares. Nesse caso, o que é certo: seguir o código ou o desejo da alma? Ou antes, a consciência tem ouvidos para escutar a alma? E a alma, tem vida para emanar o desejo? 


\section{LABIRINTO}

Para Fauzi, o teatro não é um fim em si, mas um processo de alquimia e transformação que passa pelo auto conhecimento e pela busca de harmonização entre luz e sombra. Sem maiúsculas. O maniqueísmo seria um paradigma impregnado na mentalidade atual. Boa parte dos fanáticos de todo tipo, religiosos ou político-ideológicos, incluindo workaholics, assim como seus opostos antissociais, loucos e perversos, teriam o acesso aos extremos facilitado pela negação cultural, na esfera psíquica, da integração entre "luz" e "sombra". O ser humano pleno seria, inevitavelmente, paradoxal. Não dual, mas paradoxal. Talvez isso seja simplesmente sofisticado demais para nós, mortais.

O segundo artista entrevistado foi o ator Marcelo Drummond, no mesmo dia, poucas horas mais tarde do encontro com Luciana. Parceiro principal de Zé Celso na condução da companhia, o ator está no grupo há 26 anos, desde que trocou o Rio por São Paulo e a biologia pelo teatro em 1989.

MARCELO DRUMMOND: "Não tem jeito. É o que a gente chama de "processo". Está sempre num processo. Está sempre num caminho. Não chega nunca. O teatro é uma coisa feita ao vivo, você tem que fazer todo dia. Tem que chegar lá todo dia. Não como o cinema, que você fez, está feito. Não me pergunta o texto do filme que eu acabei de fazer porque eu não sei. Agora, se você me perguntar Bacantes, eu vou falar a qualquer momento. E outras peças vão vir facilmente, porque eu fiquei ali, trabalhando todos os dias pra chegar naquilo. E toda vez que se vai fazer é uma vez. É a vez única. O Teatro tem disso."

"É um caminho porque tem um fim claro: a bilheteria. É um projeto, eu vivo disso. Sou ocidental, vivo de teatro, tenho que fazer teatro. Se não tem nada, tem que fazer uma peça pra tirar cem contos num fim de semana pra ir num supermercado comprar as coisas."

"Ao mesmo tempo eu tenho que trabalhar pra minha cabeça, pra minha alquimia. Pra eu transformar o meu estado. Porque é um estado alterado de consciência. Da mesma forma que é um ácido ou que é a Ayahuasca, é o Teatro. É um estado alterado de consciência. Você trabalha. A gente ensaia pra chegar no estado alterado de consciência daquela peça, daquela personagem. Que são máscaras das mesmas coisas: sou eu. É uma máscara de uma coisa minha escondida que eu não tenho coragem de colocar. São máscaras, mas sempre é o próprio ator. Tanto que cada ator faz um papel de um jeito diferente."

Se o teatro é um caminho, pergunto qual seria o destino alcançado:

MARCELO DRUMMOND: "É um labirinto. Eu sou um labirinto. Eu entro num labirinto em mim mesmo. Claro, existe aquela coisa, eu quero fazer a peça. Eu preciso estrear a peça. Eu preciso chegar ali num patamar aceitável pra peça funcionar com o público, senão não dá. Mas, por exemplo, o Dioniso. Onde eu vou chegar com Dioniso? Um deus bêbado que arranca a cabeça do outro porque o outro é um escroto 
e precisa perder a cabeça mesmo? Aquilo ali é uma viagem xamânica! É uma descrição de uma viagem xamânica. A viagem da morte xamânica é igualzinha ao estraçalhamento de Penteu, não tem diferença nenhuma."

$\mathrm{O}$ ator decreta que o teatro não é um caminho, mas um labirinto. Alguma coisa em sua expressão leva a concordar entusiasmadamente.

\section{SOMBRALUZ}

O terceiro artista entrevistado foi o ator Pascoal da Conceição, em 07/11/2016. Pascoal entrou no grupo junto com Luciana, em 1982, e faz parte da história do coletivo com papéis marcantes em grandes êxitos da companhia. Comecei perguntando sobre o teatro como um "caminho" de "alquimia e transformação":

PASCOAL DA CONCEIÇÃO: "Eu acho que não com tanta clareza, sabe? "um lugar de alquimia e transformação, estou vivenciando isso"... Acho que é mais assim: vou me dando conta de que vai acontecendo. Não uma coisa que eu me proponho a fazer. Não. Vai acontecendo, essa alquimia, essa mudança, vai acontecendo e eu vou vendo, "nossa, mudei... isso mudou, aquilo mudou". Alquimia é quando você pega materiais diferentes, mistura e faz outro material. Ouro. No caso do teatro, a gente também faz isso. Pega os materiais pra trabalhar, a vida das pessoas, literatura, os acontecimentos do mundo, nossos desejos, esses materiais todos que fazem parte da gente, e mistura tudo. Se fosse um químico, ia misturar como um químico. Sendo um ator, esse é o jeito de misturar. Então você faz a alquimia, a mesma mistura, mas num processo de ator. E a alquimia vai acontecer. Essa mudança, você vai mudar. Mas no caso do teatro você tem que usar o máximo possível dos seus pensamentos de ator, de trabalhador do teatro, pensando e agindo como ator. Se você não agir e não trabalhar, aí dentro, aquela matéria, do jeito que ela tem que ser trabalhada, vai entrar em outras psicologias, outros psiquismos, outros problemas. Digamos, numa peça, tem lá um namoro. Você namora a pessoa. Você pode cair nesse coágulo do namoro da pessoa. Mas o teatro é essa alquimia, de misturar um namoro pra fazer uma peça. Se você pensar como ator, vai querer fazer a peça. Pensando como amante você vai querer casar, essa coisa toda."

Vale notar que o ator é casado há 20 anos com uma atriz que começou a namorar em cena, a também fonoaudióloga Lúcia Helena Gayotto, que estava na roda de conversa no Simpósio do Oficina em 2016 como uma das mênades das montagens primordiais de Mistérios Gozosos e Bacantes, nos anos 90. A longevidade da união, que virou uma família linda, foco de luz no mundo, mostra que uma boa alquimia pode transformar "coágulos" em ouro. De um jeito ou de outro, ou se fica "entre casar e comprar uma bicicleta" ou entre dilemas potencialmente trágicos como o que viveu Fauzi com seu ator surtado na montagem de "Um Ponto de Luz":

"Ninguém atravessa ileso nenhum tipo de representação. (...) As sincronicidades que envolvem qualquer tipo de espetáculo são uma coisa surpreendente, para quem tem olhos de ver. Existe tanto a possibilidade de um casal de atores se apaixonar, se assim 
acontece no plano da ficção, como a de eles se separarem, mesmo sendo casados, caso o enredo assim determine. (...) Ao repetir, durante meses de ensaios e temporadas, palavras e gestos que lhes cabem, e revivendo cotidianamente as emoções pertinentes, os atores acabam vítimas deles mesmos. Tudo acaba se confundindo com seu inconsciente mais pessoal, e talvez seja dessa forma que acabem se identificando com seus papéis e sucumbindo à compulsão de repeti-los na vida real." (ARAP, 1998, p. 99)

No "O Teatro e seu Duplo" de Antonin Artaud, o ensaio entitulado A Encenação e a Metafísica fala de uma necessidade inerente à cena de se realizar como concretização dos conteúdos que repousam no plano abstrato: "a cena é um lugar físico e concreto que pede para ser preenchido e que se faça com que ela fale sua linguagem concreta." (ARTAUD, 2006, p. 36). Provavelmente, cada um lida com isso como pode, e o grau de consciência que se tem dessa operação, especificamente, talvez não seja determinante para seu encadeamento positivo, no sentido de favorecer os desejos ou necessidades de alma dos envolvidos. Nem sempre seria algo que se pode fazer objetivamente, mas uma daquelas coisas escorregadias que só acontecem quando você não se prende à expectativa. Mas não precisamos estar a deriva. Pouco valem raios da inspiração divina lançados sobre estruturas desprovidas de um set de para-ráios.

PASCHOAL DA CONCEÇÃO: "Tem uma alquimia proposta e você tem que agir nela, o máximo possível com um pensamento teatral. Resolvendo as coisas. No Oficina, o que eu vi, foi que todas as vezes que surgiram problemas, de uma natureza cotidiana, não poética, eles foram trabalhados do ponto de vista do teatro. Teatralmente. Por exemplo, no dia em que o dono, seu Cocoza, chegou e perguntou pra todos lá dentro: "Vocês, eu sou o proprietário do teatro, ele custa 300 mil dólares. Vocês querem comprar o teatro?" Ninguém teve dúvida: queremos comprar o teatro. Do ponto de vista do teatro, você tem que responder isso. E depois resolver isso, dentro de uma prática. Já é nosso. Daí... você vai fazer toda uma negociação alquímica para que o teu dinheiro teatral valha nessa jogada, porque você quer comprar, e querer é poder. Você vai conseguir."

$\mathrm{O}$ ator fala pela experiência do Oficina, que comprou o teatro, tendo o próprio teatro como meio da conquista. Paschoal não fala em negociações, apoios, ou o dinheiro, mas do teatro, como vetor da compra. Alquimia ou não, a posse do prédio pela companhia é fato. Eles não tinham o teatro, mas disseram "o teatro é nosso" e vieram a ter. Chega a ser bíblico: “disse Deus: Haja luz; e houve luz.” (Gênesis 1:3)

PASCOAL DA CONCEIÇÃO: "Todo oráculo tem essa dubiedade de encontrar a Luz e não a Morte. No caso do teatro, "luz" é revelar o personagem. Ter ele o mais revelado possível. Então, encontrar luz, no caso do teatro, não morrer, no caso do teatro, é fazer o personagem viver e agir. Essa coisa da alquimia, de encontrar a luz, encontrar a vida e sair da morte, essa coisa que parece existencial esotérica, no teatro tem uma praticidade muito grande." 
Fauzi propõe que: "a atração pelo palco traz, desde o inicio, a vocação para uma busca inesgotável, que implica descobrir e reconhecer toda riqueza, luz e sombra que abriga a alma humana." (ARAP, 1998, p. 57) Ou seja, o que se pede seria a integração do paradoxo primordial. Luz e Sombra. To be or not to be. Aceitação da sombra, aceitação da luz, ao mesmo tempo, cada categoria disponível em várias potências, ao gosto de cada um. A idéia de buscar a Luz pode ser influência maniqueísta - cristianismo, higienismo, etc. ou pode ser coisa de ator, na verdade, que certamente deve saber como buscar a luz em cena.

PASCHOAL DA CONCEIÇÃO: "É uma busca, mesmo (por) alguma iluminação. É engraçado porque a clareza quase cega a gente. Precisa ir pra poesia, que é esse estado de luz, esse estado de transformação. Tem que ir pra poesia. Mais do que a realidade, mais do que a clareza filosófica, didática, tem que ir pra poesia. Avançar um pouco mais. Pra lá de tudo que eu entendi sobre a peça. É um estado que faz parte do nosso trabalho de criação. De ator, de realizador, de diretor. É você conhecer, você conhecer, você conhecer, conhecer, conhecer, conhecer, saber tudo, e depois que você souber tudo, você larga tudo e vai pra uma outra coisa. Porque agora você já sabe tudo, e agora tá na hora de jogar tudo fora."

Se a meta não é a verdade, ou a clareza, mas a poesia, novamente o lembra o mito grego de Zeus, o senhor do Cosmo, presidindo da roda dos Olímpicos, não em nome de qualquer moral ou de algum "bem" abstrato, mas da harmonia cósmica. Considerando que a

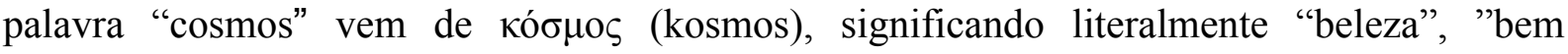
ordenado", “ornamentado". Nessa concepção mitológica, de alguma forma coincidente com a Cosmopolítica celebrada pelo diretor do Oficina, o valor que rege o universo não é a verdade, o bem, nem mesmo o mal, mas a beleza. Ou a poesia.

PASCOAL DA CONCEIÇÃO: "Poesia, na verdade, é o nome de uma coisa que tem, dentro dela, misturada, uma satisfação estética, de beleza, de satisfação humana, vontade de viver. Nesse sentido, na criação, quando você chega num ponto em que acha o que gosta, isso te dá vontade de continuar vivo, de dar continuidade à vida, de fazer mais. Esse tesão pela coisa viva, pelo que vai vir. No teatro a gente lida com a ação, não adianta falar, tem que agir. Agindo, a coisas se produz, como se fosse uma alquimia. Tem que agir. Fazer fazendo.”

Aquilo que se cria no movimento, na batedura, a Coagulatio alquímica. Mais ação e discernimento guiados pela poesia da consciência dos processos paradoxais da experiência humana numa perspectiva cósmica. Caminhos abertos formando uma nuvem negra para a chuva necessária.

\section{COMPLETUDE}


A quarta conversa registrada para este estudo, em 18/11/2016, foi com a atriz Camila Mota, provavelmente a atriz que viveu mais tempo corrido no elenco do Oficina, desde sua estréia em Ela, de Jean Genet, em 1997.

CAMILA MOTA - "a experiência do Oficina revela que a vida é um caminho. Porque é dia a dia. Claro que quando a gente vai fazer uma peça, a gente tem um objetivo, um fim, fazer um papel, fazer aquela peça, estrear, chegar naquele ponto. Mas que ponto? Não dá pra saber. A gente trabalha de uma forma que é raro ver que uma peça chegar num ponto final, as coisas sempre mudam, a dramaturgia muda, a interpretação muda, e também à partir da experiência, a única solução é entender que as coisas são um caminho constante. Numa relação de teatro vida, um caminho para alguma coisa, acho que é um caminho para viver. Mas não é um caminho para uma finalidade, acho que a finalidade é o caminho."

Se o fim é o meio pelo qual se chega ao fim, e o objetivo final da experiência é a própria a experiência, mais do que o espetáculo, o objetivo do teatro é o processo, independentemente do público. Fauzi dialoga com isso:

"Existem os que fazem, do teatro, profissão. E conseguem viver suas vidas sem risco, escondidos atras de suas personas profissionais. No meu caso, isso nunca foi possível. Nunca consegui circunscrever a magia implícita do fazer teatral ao tablado ou palco." (ARAP, 1998, p. 236)

Camila compartilha o comprometimento absoluto de Fauzi com a dimensão profunda do ofício teatral. Tampouco considera separar teatro e vida. Nem sombra e luz. Ou vida e morte. Tudo se funde, se confunde ou se integra. A atriz tem seu prisma:

CAMILA MOTA - "O teatro é um lugar onde a morte é muito presente. A gente fala muito em "morte iniciática". Da morte de alguma coisa, que precisa acontecer. Às vezes tá numa situação de ensaio de uma determinada peça que precisa morrer alguma coisa em mim. Eu preciso ter algum tipo de morte. Então a morte é uma coisa muito celebrada. É maravilhoso morrer no Teatro Oficina. Toda vez que se faz um papel em que se morre, é ótimo, porque você sempre ressuscita de alguma forma maravilhosa. (...) claro que tem momentos que dá medo da morte. Num avião, num momento assim. Mas o trabalho no Oficina tem essa relação com a morte, sempre, diária, um dia a dia de mortes... Tem na "Cacilda 1" uma frase da Silvinha, que era a "Jovem Atriz 2", um papel que era a Silvinha Werneck, uma parceira do Samuca, do coro de "Roda Viva". O Samuca e a Silvinha são personagens de toda saga de Cacilda. Eles são a Nina e o Treplev de "A Gaivota", uma peça que entra na dramaturgia. Era encenada a morte da Silvinha, que morreu depois na África de mutilação genital, namorou um africano que era tabu, uma história muito doida, e ela morreu. E tinha, na encenação da morte e a ressurreição dela, uma frase muito bonita que eu demorei a entender, era difícil falar: "Eu tenho sempre a frescura da recém morrida." Que não é a frescura da recém nascida. Não é só um jeito de falar, uma entonação, você tem que entender o que é sentir a frescura de uma recém morrida. $\mathrm{O}$ contato com uma morte, que te dá um frescor muito grande. Então eu acho que é mais do que um caminho pra juntar, ou pra passar da escuridão pra luz, é um caminho que contém luz e contém escuridão, como opostos complementares e necessários.” 
Talvez o caminho da integração entre "sombra" e "luz" seja feito de encruzilhadas em decomposição, onde os sentidos se unificam sem lógica, e a dualidade se mantém como opção para os saudosistas:

"Talvez, como na alquimia, as coisas estejam relacionadas de uma forma que nossa visão científica não seja capaz de compreender, e nossa postura esquizofrênica, que pretende separar o que é espiritual do que e material, é que esteja na origem dessa confusão. Talvez haja uma relação dialética entre esse par de opostos, e forçar numa direção qualquer equivalha a fazer o contrário.” (ARAP, 1998, p. 264)

\section{ESCOLHAS}

LUCIANA DOMSCHKE: "Se você não dá mais importância para coisas que você dava, quer dizer que morreu isso, renasceu aquilo? Realmente, tem células morrendo e renascendo. Mas eu quero que isso aconteça a partir de uma escolha que eu fiz, que é a vida. Aí, a loucura é bem vinda. (...) Porque a fonte da vida te sustenta. É uma relação viva. Uma coisa que se transforma. E portanto gera o sustento. É fundamental não abrir mão da liberdade. E a liberdade que eu prezo é uma me permite dizer não.

Entre a liberdade que se experimenta e a que se deseja, a construção de uma peça expõe o inconsciente aos símbolos ativados pela cena, trazendo efeitos colaterais não causais na vida dos envolvidos. A liberdade é sempre um risco conhecido por qualquer gato de rua, lembrando que gato caseiro é quase sempre castrado. Talvez porque a criatividade cresce na liberdade mais íntima, aquela da criança sem noção no centro de todo gesto criativo:

PASCOAL DA CONCEIÇÃO: "No teatro, você vai trabalhar com a sua liberdade. Olha onde você tá entrando! Olha só o que você pode alcançar com a sua liberdade! É a sua liberdade que você traz para a cena. E ela não pode, por exemplo, ser submetida à qualquer outra coisa que não seja você mesmo, porque é a sua liberdade. Liberdade democrática, liberdade humana, liberdade poética, é a sua liberdade. Não é rebanho, do tipo, vamos seguir Jesus, deus, diretor, quem seja. Não. É, e tem que ser, obrigatório que um espetáculo trabalhe com a sua liberdade. Com a sua opção libertária. Eu vou entrar em cena, eu posso fazer tudo o que eu quiser. Quando eu entro em cena eu posso assim, eu entro pra fazer o que eu quiser. E porque eu vou fazer o que eu quiser, eu tô numa potência que precisa até tomar cuidado, senão eu faço tudo que eu quero. E quando eu me lembro que eu posso fazer tudo o que quiser, quando eu penso que tem que fazer só isso do personagem, eu acho até bom, pra não ter muita coisa pra fazer. Porque se eu puder fazer o que eu quiser, fica demais pra mim. Ainda bem! Tem os limites do personagem, ótimo. Vou nesse limite até onde o personagem vai. Acho isso bom, no caso, porque é com a tua liberdade que você faz os personagens. Tem que ser com a sua liberdade. Imagina você fazer um personagem que o diretor diz como que é, como que vai ser e tudo mais, tatatata... Imagina! Ele pode dar as indicações, os toques, mas você tem que ter a liberdade de fazer."

No teatro, seria preciso aprender a pilotar a própria liberdade antes de se pretender uma criação verdadeira. Sem desprezar o risco do aprendizado, nem esperar que o caminho seja fácil. A liberdade pode ser uma professora cruel. 
MARCELO DRUMMOND - "O caminho é ensaiar. O trabalho é levantar aquilo todos os dias. Toda semana. Se a peça não foi bem numa semana, tem que ir melhor na outra. E não só de público, tem que dar uma ensaiada, mexer alguma coisa. Se as pessoas estão mecânicas, tem que dar uma mexida. Quando a gente faz bem, você vê os olhos dos atores brilhando quando saem de cena. Claro que quando eu olho pra mim depois da peça, é todo esbugalhado, tudo aberto. Mas você vê os olhos dos atores brilhando. Eles passaram por alguma satisfação maior. Mas pra atingir a satisfação você passa por várias coisas, às vezes cenas crudelíssimas. Terríveis. Mas a alegria está em passar a cena terrível. Pra você conseguir fazer aquela cena, você superou momentos terríveis, seus. E esse caminho, você não sabe muito. É um labirinto. Você entra e é zona de sombra, luz, e quando você vê, às vezes nem sai mais. Fica preso ali naquele labirinto e não consegue resolver nunca."

A analogia com o processo de Fauzi criando o Tiêteriev é clara. O risco de um alquimista se perder no próprio laboratório simbólico é conhecido pelos que desbravam os labirintos das ideias, como Artaud e seu pensamento sobre $O$ Teatro e a Peste:

"Pode-se dizer agora que toda verdadeira liberdade é negra e se confunde infalivelmente com a liberdade do sexo, que também é negra. (...) há muito tempo o Eros platônico, o sentido sexual, a liberdade de vida, desapareceu sob o revestimento escuro da Libido, que se identifica com tudo o que há de sujo, de abjeto, de infame no fato de viver, de se precipitar com um vigor natural e impuro, com uma força sempre renovada, na direção da vida.” (ARTAUD, 2006, p. 27)

MARCELO DRUMMOND: “O Zé, quando dirige, ele diz o que não é. Agora, o que é, você vai ter que descobrir. Ele pode dirigir a fala, alguma coisa, mas o que mais se ouve do Zé é: "Não!!!”. Aí, tirando o que não é, o ator vai buscar outros caminhos. (...) É o ator quem dá significado às coisas. Cada coisa, tem que fazer valer. Aquilo está ali na sua frente e tem que ter, não uma função dramática, que pode até ser, mas cada coisa tem um significado. Você precisa imaginar a vida assim também. É tudo questão de interpretar as coisas que estão na sua frente."

Novamente a imagem da realidade como linguagem surge no fluxo de pensamento de um ator diretor que vê a vida como "cena" ou como um tempo espaço "cheio" de "coisas" com função dramática e significado. Mas Fauzi é mais cuidadoso nas suspeitas:

"Um poeta tem da Vida uma leitura particular, que o ajuda a enxergar além. Pessoalmente, foi o teatro que me ensinou a enxergar, na Vida, suas estruturas internas. E vivemos todos mergulhados continuadamente num psicodrama não apenas social, mas cósmico, que reflte todo tipo de estrutura que faz a Terra se mover." (ARAP, 1998, p. 239)

A imagem de um psicodrama cósmico coloca o próprio cosmo na posição de paciente num consultório psiquiátrico.

MARCELO DRUMMOND: "Dizem os magos e os pais de santo que você tem que saber interpretar as coisas que estão à sua frente pra seguir o seu caminho no melhor. Por onde você for, vai interpretando, que tem sinais que vão lhe dar... Eu não fico buscando sinais, tem que deixar a vida andar. Agora, em cena, sim. O teatro ensina isso. Ensina você a olhar. Quando eu olho pra uma pessoa conversando, eu sei o que ela representa, de alguma forma. Você começa a descobrir. Não as ideias dela, mas o que ela representa. Você saca as pessoas que estão querendo representar uma coisa 
que não é. O tom de voz, você interpreta, antes do sim ou do não, seja do que for, um beijo ou um patrocínio de um milhão. $O$ teatro ensina a relação humana. Estudando os personagens, você começa a ver todo mundo como personagem. Que personagem é aquela pessoa naquele momento? O que ela representa? As vezes não quer dizer nada, você encontrou uma pessoa, simplesmente. As pessoas não sabem interpretar mais nem notícia de jornal. Tem muito ator que não interpreta.Pode até representar, mas não sabe o que aquilo quer dizer. O teatro é uma brincadeira, é mentira mas é de verdade. Você começa a viver aquilo de alguma forma.

O mistério da cena seria essa chave das estruturas internas que "fazem a terra se mover”. Se o universo se traduz num drama cósmico, psicológico ou não, drama é arte, e arte é estética. A essência do mundo é a arte da forma:

CAMILA MOTA - "é importante você ter uma prática e um desenho que mude. Tudo que se faz, com todo o corpo, a mão, o olhar, todas essas coisas, todo esse rendilhado é importante pra dar vazão à ideia. Pra você desenhar. Uma ideia possibilita muitas interpretações. E a gente trabalha com multidões. São, no mínimo, 60 ideias multiplicadas pelo número de espectadores que vão entrar em contato com essa ideia. $\mathrm{O}$ acabamento do espetáculo, o roteiro, o rendilhado de cada atuação, tudo ligado à esse campo estético, tem que existir. De alguma maneira, esse rigor de escola de samba faz parte da interpretação da ideia."

O rigor é necessário para que se concretize o signo, a alegoria ou o símbolo da cena. Essa ideia conversa com $O$ Teatro da Crueldade de Artaud: "criado para devolver ao teatro a noção de uma vida apaixonada e convulsa; e é neste sentido de rigor violento, de condensação extrema dos elementos cênicos, que se deve entender a crueldade sobre a qual ele pretende se apoiar.” (ARTAUD, 1984, p.95) A vontade da cena encontra seu caminho e sua voz no processo:

LUCIANA DOMSCHKE - Ele dizia: "Sai da zona de conforto, sai do que você sabe mais ou menos ou do que você pensa que sabe, e se arrisca, ousa!"

O Teatro se afirma como território livre num tempo distópico em que a liberdade é uma palavra em parte adulterada, usada para dourar pílulas, iludir "zumbis" ou "agregar valor", inclusive cultural, mesmo sendo liberdade strictu sensu, impossível para a quase totalidade da população. Algo no teatro, do grande musical ao teatro documental, é como um bunker de sementes no polo norte guardando a essência da liberdade para que não se perca seu verdadeiro DNA ao longo dos séculos de mutações, dificilmente evolutivas.

LUCIANA DOMSCHKE: Muito bons eram momentos de música e dança. De alguma maneira, ia acontecendo, um contagiando o outro e a gente conseguia momentos inesquecíveis. E a partir desses momentos de criação, mais esparsos, a gente tinha que trabalhar, muita repetição, muita exposição das limitações de cada um, das dificuldades, da intolerância. O prazer era coletivo quando a gente conseguia um salto pra um entendimento maior. Quando via, tinham passado 12 horas de ensaio!" 
Diria Beckett que "o tempo passa quando a gente se diverte".

PASCOAL DA CONCEIÇÃO: "eu tenho que gostar de fazer esse personagem. Eu tenho que ter prazer de pesquisar, de ver quem ele é, de fazer ele viver. Tem que tocar esse prazer.

\section{PRAZER EM CONHECER}

O prazer que gera a vida. O prazer que transforma o desejo em ouro. A indústria que domina o mundo. O prazer mais singelo da alegria mais simples:

PASCHOAL DA CONCEIÇÃO: "Tem que buscar esse prazer. Qual é o prazer de fazer esse personagem? Onde tá o prazer dele pra ele fazer o que ele faz? Ir ao encontro desse prazer. Mais do que saber se ele é bom, ruim. Mais do que isso. Buscar o tesão que ele tem naquilo. O tesão de fazer viver, deve ser o mesmo tesão de um escorpião cheio de veneno. Um tesão de estar vivo e poder dar uma "tss!", matar alguém. É um escorpião, mas ele quer ficar vivo. (...) É isso que você faz. Buscar no personagem o que tem dentro dele que quer viver. Que tá afim de ser vivo. Porque isso contribui realmente pra essa alquimia. A mágica talvez seja buscar esse negócio do desejo. É uma mágica, não é um truque. É um truque mágico. Precisa prestar muita atenção pra ver onde é que ele tá. O prazer. Aí, quando você descobre, você vai em frente."

O prazer seria uma chave, um filtro que revela um caminho das pedras da grande arte.

Talvez como propunha Artaud no Teatro da Crueldade:

As imagens e os movimentos empregados não existirão apenas para o prazer exterior dos olhos e dos ouvidos, mas para o prazer mais secreto e proveitoso do espírito. Assim, o espaço teatral será utilizado não apenas em suas dimensões e em seu volume mas, por assim dizer, em seus subterrâneos. (ARTAUD, 1984, pag. 146)

Se realmente procede a suspeita de que a encenação tem o poder intangível de transformar os envolvidos, o prazer seria a melhor das opções.

CAMILA MOTA - "Fazer Cacilda é fenomenal. Foi um trabalho de buscar uma forma, justamente, e foi a primeira vez que eu trabalhei assim no Oficina, de buscar uma voz que não era minha. Mas ao mesmo tempo aquilo era pra atingir a alma, o corpo da alma. Aí quando você atinge, tem aquela vitalidade, aquela coisa, aquele entusiasmo, aquelas exclamações todas. Quando você começa a viver aquelas exclamações, é maravilhoso viver assim. Ainda mais hoje em dia, com todo mundo deprimido. Todo mundo toma rivotril porque tá foda mesmo, aí você pega uma personagem que é uma cabra da paixão, que vai que vai que vai que vai, porra! é foda viver isso, maravilhoso, incrível."

Mas o prazer é mais uma dimensão psíquica difícil de pilotar, com implicações inconscientes mais ou menos selvagens que podem fugir ao controle. Seja poéticas ou sutis as rachaduras nas barragens dos limites inexistentes entre o instinto e a cultura, o prazer é facilmente transfigurado. 
LUCIANA DOMSCHKE: "Por exemplo, quando eu fiz "Os Sertões", o pai dos meus filhos foi trabalhar lá. Na iminência da separação, foi o momento em que a gente mais trabalhou juntos. Horas de ensaios. E a cena do Senhor de Engenho em "O Homem", ele colocou meu (hoje) ex-marido de senhor e eu de senhora de engenho. Ele comprando escravos e tendo uma relação sexual com uma escrava. Não sei se eu que inventei ou se foi o Zé quem foi inventando. Eu ia pra senzala numa cena que foi capa da Ilustrada: eu com pele branca no contraste com a pele negra dos homens todos. E antes de ir, eu dava um tapa na cara do senhor de engenho. E foi uma dificuldade, eu não conseguia dar o tapa. Não conseguia, mas era o que eu mais queria. O Zé armou pra eu dar um tapa na cara do cara. Eu tava chateada, mas não era esse o meu caminho. Eu lembro que, finalmente, o dia que eu dei o tapa, o elenco inteiro aplaudiu e comemorou, todo mundo querendo ver eu dar um tapa. Eu não sei se isso acabou tendo um sentido ou não, mas eu me senti, de alguma maneira, conduzida. Não sei se isso me elucidou, me resolveu a vida ou me transformou, mas aconteceram coisas assim. Tudo isso fez parte."

Tudo parece fazer parte de alguma coisa, como um fractal dinâmico que se revela em acontecimentos aparentemente desconexos:

\begin{abstract}
“As emoções humanas não existem apenas para serem vividas, mas são matéria-prima desse trabalho. E devem ser transmutadas, trabalhadas, reelaboradas e decifradas. Para o místico, essa descoberta se esgota nela mesma, ele é um civil. $\mathrm{O}$ ator é um soldado da alquimia possível da personalidade.” (ARAP, 1998, p. 236)
\end{abstract}

Mesmo quando o paralelismo entre cena e vida parece soar como alusão a uma poética distante, logo revela um pensamento estritamente teatral:

PASCOAL DA CONCEIÇÃO: "uma coisa sobre o Rei Lear, a cena da tempestade, em que ele fala com os trovões, de certa maneira, a tempestade é o estado interno do personagem. Como quando você tá numa tempestade, não sabe se você vai pra lá, pra cá, ou o que vai fazer, você tá nessa tempestade. O Lear na tempestade, o que tava dentro dele tava espelhado na própria natureza. (...) os caras bons de dramaturgia, eles põem gente falando, mas eles põem correntes energéticas, uma contra a outra. Não é só gente, são pensamentos, modos de ver a vida, modos de ser, trangêneros, cientistas, ator, filósofos, jeitos de ser, são forças. E quando você começa a mexer com essas histórias, com essas forças, você começa a trabalhar nela, começa a prestar atenção em como é que ela vem, como é que ela se manifesta, qual que é a sutileza dela dentro das outras forças da vida. Digamos, quando eu tava criando o Polônio, eu tava muito ligado na coisa da burocracia, de como ela se manifestava no Estado, como que ela era importante pro "reino". Então, fazendo Polônio, toda essa informação foi se desdobrando. E engraçado que, ao trabalhar com essa energia de Polônio, no teatro Oficina, eu acabei virando administrador do teatro, o livro caixa, os contatos com o governo do Estado. E da minha vida mesmo, resolvendo meus problemas do banco, em casa... Aquela sabedoria que tava dentro do Polônio, uma espécie de coisa guardada dentro dele, como se fosse um perfume, então aquele perfume vinha pra fora nessas atitudes, eu conseguia por pra fora aquele perfume, aquele negócio. $\mathrm{Na}$ vida pessoal e no próprio teatro.

A personagem é um perfume, e o prazer move o mundo. Tudo se domina para que o prazer aconteça, todos investem no prazer e assim caminha a humanidade. Mas o prazer também surge como um Mestre oculto desafiando o caminhante. Nos bastidores da tragicomédia orgia, o perigo do paralelismo entre cena e vida fora da verdade do espetáculo é 
suavizado pelo "amor aos fatos" que favorece a arte na dimensão poética das forças que movem a realidade, dimensão onde tudo tem o próprio sentido.

PASCOAL DA CONCEIÇÃO: "o personagem chega pra gente. Ele chega pra você e se apresenta. Você recebe ele: tem a peça, tudo que você gosta, vem o personagem que você gosta. E esse personagem tem uma vida dentro dele. Ele responde à essa vida. A esse negócio que é a vida dentro dele. Ele responde, tem ações, tem pensamentos respondendo essa vida dentro dele. Ele nasceu pra aprontar. Tem que fazer o que ele tem que fazer. Ele quer fazer alguma coisa. Ele tá lá com aquela coisa. Como é na gente mesmo: tem um negócio lá que quer fazer alguma coisa, ou não quer fazer nada, esse negócio, esse comichão, é o que o ator pega pra ele. $\mathrm{O}$ ator entra nesse lugar desse comichão, que a gente chama de vida, a gente chama de beleza, a gente chama de arte. Mas ele entra nesse comichão do personagem. É uma cosseguinha que o personagem tem, e aí o ator se coça tanto quanto teu personagem. É uma cócega."

\section{EVOÉ PARADOXO}

A alquimia, do ponto de vista psicológico, descreve os caminhos da alma em direção à um destino tão eterno quanto inevitável: sua própria realização como fenômeno completo. Dioniso é o deus do Teatro, um deus que subiu ao Olimpo depois de mostrar seu poder espalhando o êxtase da alegria, do vinho, do sexo e da arte da representação. E se tornou um entre os paradoxais deuses Olímpicos, cujo conjunto representa a harmonia do Cosmo. O deus dos deuses, Zeus, simboliza o equilíbrio absoluto, a Luz, e mesmo sendo o chefe e sendo o mais incrível, é mais um na roda. A combinação harmoniosa desses paradoxos que representam cada um dos Olímpicos é o equilíbrio que transforma as coisas, do Caos aos Cosmo. Do nada à poesia. Boas ou ruins, cruéis ou gentis, só importa a harmonia na consciência do paradoxo, consciência que revela a beleza inexorável por trás de qualquer coisa. Nesse sentido, seria pra isso que a gente existe: pra ser bonito. Não para ser bom. Mas um tipo de beleza feita da consciência desse paradoxo e da capacidade de vivenciar, ao mesmo tempo, a dimensão terrível e a dimensão maravilhosa de tudo.

PASCOAL DA CONCEIÇÃO: "De certa forma isso é a tragédia. A tragédia, que é o que nós somos. É o que é. É o que temos. O que está acontecendo agora. A gente é trágico, não é dramático. Porque a tragédia é assim: quando ela entra na tua frente, ela te põe no movimento. Você anda. A tragédia não é dramática, do tipo "será que ela me ama, será que não me ama, não sei se tô bem, se não tô, será que eu vou morrer, será que não"... A tragédia, ela já te coloca em ação direto."

MARCELO DRUMMOND - "No teatro, o ator é verdadeiro se ele consegue ser, consegue viver aquilo. Ter a catarse. Chegar numa coisa que realmente mexe com você. E você sai daquilo, não ileso, mas transformado. (...) seja pelo físico, uma coisa aeróbica, mais adrenalina, mais endorfina, com suas drogas interiores, suas próprias drogas, você consegue levantar e sair melhor. Porque, na verdade é isso, o ator é um viciado em adrenalina. (...) É mais viva do que a vida, a sensação de vitalidade que se 
tem em cena quando se faz uma coisa boa. É questão de você estar vivo em cena. Mais vivo do que na vida. (...) O personagem, de repente, ganha voz. É mágico, não é uma coisa que você pode ficar planejando. De repente, o personagem tá vivo e vai em frente. É uma força inteligente. Ele é uma inteligência. Se você deixar, foge do controle. E tem um lado que você deixa fugir do controle. (...) é tudo Exu de Umbanda, os personagens. Trafegam em mundos mais escuros, normalmente, e as vezes você pega ali. (...) E não é uma errada, não tem isso. É o que é. E tem sempre a possibilidade de ir completamente pro buraco. Ou não. (...) Um personagem feito Hamlet. O Hamlet tem um espírito. Já foi feito tanto, é um espírito. Dioniso, já foi feito tantas vezes que já é um Espírito. Já é uma coisa. Como Jesus Cristo, independente de ter sido aquela pessoa ou não, não importa, viveu porque viveu em muita gente. É uma energia. Significa uma energia. Dioniso significa uma energia. Penteu significa uma energia. No Candomblé, o Pai de Santo fala "Põe um copo de vinho pra ele porque isso já é um espírito, já é uma coisa.” Dioniso, Hamlet, todos esses personagens, já estão na cabeça das pessoas, elas já projetam aquilo. Tem uma energia ali, projetada. E você tem que pegar aquela energia. Mesmo que você faça diferente, não importa, não tô falando de estética, tô falando de uma energia. E o ator fica de catalizador, fica puxando aquela energia. (...) você é meio comandado naquilo. Se a gente resolve bem, no teatro, resolve bem no teatro. Se não resolve bem no teatro, a coisa vai ficando na vida, meio pendurada."

A fala sugere uma personagem viva para além dos textos e outros registros, filho também das impressões e reflexões de quem leu e da ressonância de todas as suas representações anteriores ao longo do tempo, formando uma entidade autônoma, senão física, ao menos fisicamente acessível através da atuação:

MARCELO DRUMMOND: "Passa por você. Passa pela tua cabeça, o que você tá dizendo. (...) depende da tua interpretação, de você interpretar o mundo. Daí você leva a peça pra sua vida. Você começa a interpretar tudo à partir daquele ponto de vista da personagem. E não tem certo e errado, é um ponto de vista. A maneira que o personagem interpreta o mundo. (...) Cada um é um personagem a cada momento. Ninguém é de uma maneira só. Todo mundo muda toda hora. Não fica ali só naquela coisa. A vida não é linear."

\section{VIDA CENA}

O teatro é a arte feita de vida. Uma linguagem a partir de significantes vivos, com respiração, carne e osso, ação, consciência e voz agindo num tempo e espaço definido.

FAUZI ARAP: "Eu ainda não me dera conta da necessidade de administrar a realidade paralela à própria peça" [e os] "perigos implicitos ao paralelismo entre encenação e vida, quando não existe um compromisso real com a verdade abordada por texto e espetáculo." (ARAP, 1998, p. 236)

Seriam graves estes "perigos" do paralelismo entre encenação e vida? De atores e atrizes a sonoplastas e iluminadores, muitos têm histórias para contar. Mas nada importa quando a certeza é de que o importante é o papel. A personagem. O resto seriam ossos do ofício. Se a entrega for demasiada, porém necessária, a opção conta. 
MARCELO DRUMMOND - "Seria como uma incorporação na Umbanda. De certa forma é o que a gente faz: incorpora o personagem. Com os defeitos, não só as qualidades. Pega tudo. Às vezes se consegue deixar os defeitos lá e depois, no fundo, você aprende o que são as qualidades. (...) Mas às vezes a gente cai nos defeitos das personagens, total, no pior do personagem. Você absorve tudo. A sabedoria do Teatro é você dominar realmente. Porque não existe: 'eu tiro o personagem, deixo no teatro e vou pra casa.' Tá dentro da minha cabeça, não tá no teatro. Tá em mim. Tá no meu corpo. Ao mesmo tempo você faz com a cabeça, tem um lado que é consciência. (...) Meu corpo, meu fígado, meu pé, minha dor. A dor no meu ombro. A dor no meu joelho. Isso é o meu corpo. Mas eu tenho um corpo sem órgãos que o personagem toma conta. Que é essa coisa que fica ali. E você pega ali e vai levando pra vida. (...) Eu sempre transformo em mim. Se eu estou fazendo Navalha na Carne eu sou mais escroto no trato com todo mundo, começo a falar meio escroto, fico com aquele negócio natural em mim. Eu entro no barato do personagem. Fico jogando aquilo ali. É claro que tem limite pra tudo. Eu brinco com os limites. Ao mesmo tempo, outro dia eu tava pensando 'será que eu sou maluco mesmo? de tomar remédio, maluco doido?' Que eu sou maluco, ok, todo mundo sabe. Mas será que eu sou doido mesmo, que eu incorporo assim o personagem? Entro naquele personagem e acredito? Eu tenho que acreditar, é meu trabalho. Mas é o trabalhar no limiar da loucura. É muito fácil um ator ficar maluco de vez. Ou ficar careta de vez. Ou não aceitar aquela zona de sombra de jeito nenhum, porque surtou de alguma forma."

Se a encenação em carne, osso e ação no tempo espaço potencializa o efeito dos significados ativados na cena, parece razoável que se busquem meios para se administrar uma realidade sob tal efeito alquímico. Ou talvez essa intenção seja muita presunção diante da força arrebatadora que se pretenderia administrar:

CAMILA MOTA: "Eu casei com o Fernando fazendo Boca de Ouro. Ele fazia o Leleco, eu fazia a Celeste, a gente tinha meio começado a namorar há uma semana, e o Zé falou: "a gente já tem o elenco, Celeste e Leleco." E acabou que a gente casou. Só que era uma peça complexa porque eu esfaqueava o cara duas vezes na peça. Então teve um momento em que isso começou a dar muito errado. A gente ficava até as 7 horas da manhã, em casa, rolando na cozinha com faca no pescoço um do outro, porque ele terminava muito arrasado que eu matava ele. A gente chegou e falou assim: não! Vamos inventar um rito de terminar a peça. A gente tem que cortar. Tem que acabar a peça. É uma coisa assim bem, quase careta assim: tem que acabar a peça, dar um abraço e não sei o que, deixar passar aquela coisa assim que a gente tava misturando. Ao mesmo tempo foi ótimo fazer assim misturado, porque tinha uma intensidade, uma vontade de viver tudo ao mesmo tempo, que foi muito potencializador."

MARCELO DRUMMOND: "Vai entrar na vida da pessoa de qualquer maneira. Ela vai ficar repetindo aquilo, não vai conseguir repetir mecanicamente sempre. O elenco se comunica com falas do teatro, começam a falar as coisas que se fala na peça, de repente, são 70 pessoas que falam comigo dizendo falas da peça, minhas, dos outros, cada um, todo dia, todo momento. E é como uma oração. Ou como um mantra. Uma reza. Uma coisa que funciona, ativa, provoca determinadas coisas em você. Um dia, o negócio bate. Um dia bate diferente e não tem como não descobrir uma coisa nova na vida."

CAMILA MOTA: “A gente se separou em cena, também. Tava num momento dos Sertões que, se um dos dois saísse, a gente não ia mais viver. Então tinha uma cena do Riobaldo e Diadorim, da separação dos dois. E aí, isso foi feito no dia 13 de Junho de 2003, num ensaio aberto de Sertões, foi o último ensaio que o Fernando fez de Sertões, ele tava saindo da companhia, ele fazia o Riobaldo, eu a Diadorim, e a gente 
fez cena dizendo "então é isso aí, cada um vai pra um lado etc." E aí, foi a nossa separação. E deu pra ver isso. Foi vivido."

Dada a reincidência ao longo de coros e das décadas, é natural que tenham se desenvolvido alguns procedimentos ou práticas do elenco buscando manter em ordem as distinções energéticas entre o trabalho sobre a cena e a vida cotidiana.

PASCOAL DA CONCEIÇÃO: "No Oficina a gente insistia muito nisso que era o seguinte: como se você abrisse possibilidades. Os portais de possibilidades. Quando começava o ensaio, abria; quando terminava, a gente fechava esse lugar. Abria o processo, fazia fazia fazia, depois fechava o processo. Sempre o ensaio abre, depois fecha. Ritualisticamente: todo mundo dá a mão, começa a respirar, e djuns, fuhhh! Merda! Começou, tal. Vai vai vai, fala uma coisa, outra coisa, ninguém fala, faz aquilo, faz aquilo, faz aquilo, confusões, falam, gritam, vem desordem, quizomba, tal tal tal, meia noite, terminou, todo mundo dá a mão, ok, a gente vai fazer o seguinte e tal, faz aquela reunião hiper prática e tal, amanhã as duas, às três, ok, ok. Merda! Acabou, vai pra outra coisa. É um período em que fica estabelecido um tipo de atitude, um tipo de conduta, de compromisso, esse tipo de coisa. Claro que você faz isso, você fecha, mas você sabe... Aí você vai pra casa pensando tudo aquilo e tudo mais, e amanhã você tem que voltar."

Os casos extremos de paralelismo entre cena e vida são riscos assumidos por quem

busca a integração entre as múltiplas dimensões da experiência teatral:

CAMILA MOTA:"Desde que eu vim trabalhar no Oficina, descobri que uma coisa tinha a ver com a outra. (...) antes, não tinha nenhuma relação. Pelo menos eu não sacava que aquilo tinha uma relação direta com a minha vida, que uma coisa que eu estava vivendo era diretamente influenciada por aquilo. Hoje em dia, se eu não vejo esse sentido, tenho até dificuldade de trabalhar. Aí, quando eu assisti o Hamlet, eu saquei isso, que tinha alguma coisa a ver, eu achei aquilo muito fascinante, eu quis vir pra São Paulo trabalhar porque eu queria que a minha vida fosse uma coisa só. Que não fosse um espaço pra isso, um espaço pra aquilo. Eu não tenho muito esse conflito (...) eu saquei que eu podia ser uma pessoa muito mais interessante, não pra mim, pra si, pro Sol, pra todas as coisas.

Mas qual seria esta qualidade específica do teatro que torna interessante tal entrega ao ofício, a ponto de desejar o fim dos limites entre vida pessoal e atividade profissional?

CAMILA MOTA: "O Zé sempre fala, desde que eu entrei, que a gente não deve julgar um personagem, porque o personagem tem muito mais possibilidades do que a gente. Tem muito mais liberdade. (...) Eu fiz a Cacilda quando fazia Dama das Camélias. (...) não se faz mais a Dama das Camélias porque não tem mais a ver, é um dramalhão (...) eu tive que me jogar, não julgar aquela mulher. Porque, quem sou eu, aqui em 2016, que acho que sou bem resolvida na minha vida ou não, pra chegar e achar que sou mais do que aquela personagem? Ela é muito mais que eu, é a personagem escrita, é o personagem que eu vou fazer, que a Duse fez, que a Sara Bernardt fez, a Isadora Duncan também fez. Então o personagem já tem muito mais possibilidades porque vai ter muitos intérpretes, que vão ver outras coisas que a gente nunca viu. $E$ acho que a gente aprende a viver melhor. $O$ fato de você fazer outros personagens, um personagem que é diferente de você, que faz coisas que você não pensa em fazer, é maravilhoso, porque te dá um outro ponto de vista. Você começa a pensar que você poderia ver alguma coisa, essa farofa com arroz feijão aqui, hoje, se eu tô fazendo uma ou outra personagem, eu posso ver ela com outras perspectivas. E 
isso é um exercício de vida, principalmente. (...) Mais do que se confundir, é um bastão que você pega por um momento da vida. Em que você vai ver a vida daquele ponto de vista. Ele vai entrar, vai confundir nesse sentido. É uma confusão necessária porque você vai enxergar de uma maneira que eu nunca pensaria em enxergar. (...) você pega emprestado aquele ponto de vista, pra ver as coisas, então a minha vida mudou muito à partir disso. E ela muda muito à partir disso. É maravilhoso."

As palavras sugerem uma espécie de simbiose entre as essências da atriz e da personagem, que facilitaria a absorção dos dons (e defeitos) de uma pela outra. Uma tal simbiose de essências talvez dependa se antes o ator ou atriz tem contato com a própria essência. E do quanto um artista estaria ativo ou passivo neste processo de lidar com a personagem enquanto inteligência autônoma a ser decifrada. Um estado de simbiose conquistado, uma outra Coagulatio - a operação alquímica de solidificação que traz o equilíbrio do processo para o recomeço. Possível na medida de uma habilidade que se desenvolve quando se estuda a personagem, se pesquisam gestuais, motivações, emoções ocultas, entrelinhas, se descobrem os sentidos que os mantém vivos, e com isso absorvem seu conhecimento, sua "experiência de vida", que exercitam em cena, nos ensaios e espetáculos. Nessa experiência teriam a oportunidade de adquirir dons. Os dons das personagens, novamente encarnados numa consciência e num corpo humano. Sólido.

CAMILA MOTA: “É como uma ferramenta mágica. Que você pode usar, o que você quer ou o que você não quer. Porque na antropofagia se come uma parte e se dispensa a outra. A digestão é natural. Faz parte.

A ideia é que um ator, ou atriz, ao realmente decifrar e pegar o personagem, poderia usar as qualidades dele. Absorver os dons e os defeitos dos personagens, e na medida da sua consciência do processo, poderia usar isso na vida. Mas se não decifrar totalmente, corre o risco de voltar ao caos que Fauzi precisou enfrentar .

FAUZI ARAP: "Os ensaios acabavam mobilizando nos atores as mesmas questões, de forma visceral, desencadeando crises análogas às que estavam no texto. (...) As dificuldades e conflitos dentro dos grupos imitavam a atmosfera dos problemas que o palco estava retratando. (...) A sincronicidade entre os fatos relatados e os bastidores do espetáculo se confundiam.” (1)

CAMILA MOTA: Na Macumba Antropófaga”, em 2012, a gente encenava a história da Elaine, nossa diretora de video que teve uma história barra pesadérrima, começou a namorar o Fred, que faz o Penteu, e o marido, que já era ex-marido, começou a surtar, acusou Elaine e Fred de pedofilia com o filho deles, tudo mentira. Ela morreu de câncer, e o cara ficou proibido de ver o próprio filho. E eu fazia a Elaine na Macumba, em 2012. E viver isso foi, assim, bem bizarro. Foi um desses momentos que o negócio parece que não dá muito certo. Eu até achava que sabia o que estava fazendo, mas foi difícil. Talvez o momento mais difícil, uma bad trip bem radical esse papel (...) às vezes é bastante doloroso, mas compensa. Não tô aqui dando uma fórmula de 
felicidade, dizendo que minha vida é incrível, linda maravilhosa. Não é. As vezes a gente passa por alguns buracos. Sempre. Eu tive pneumonia fazendo Cacilda. Inclusive. Mas raramente eu lembro disso. Óbvio que eu lembro disso como processo, mas é que eu acho que, pelo que eu ganhei, valeu a pneumonia. Tá tudo certo.”

LUCIANA DOMSCHKE: "Eu teria que ser mais poeta para conseguir falar do que foi. No meio de tudo eu via perversidade também. Mas eu buscava sempre não julgar, não suspeitar (...) corajosamente, apostar tudo ali e ver no que ia dar.

\section{CAMPOS ELÍSEOS}

Fauzi falou sobre um dos infernos da lida teatral, sem descrevê-lo, só definiu seu oposto na própria consciência do teatro como a Grande Arte:

FAUZI ARAP: “Quando se absolutiza a coisa estética do teatro, pode-se incorrer no erro de trancar-se num inferno particular. Para mim, desde o início, intuí nele uma forma de alquimia e transformação".

Esse risco de "absolutização da coisa estética do teatro" seria, talvez, o de se desprezar as dimensões mais instáveis da cena, ativas no Inconsciente. Intuitivamente ou não, alguns vivem a consciência desse paradoxo numa intensidade que se reflete no brilho de suas personagens. Mas o risco não se extingue:

LUCIANA DOMSCHKE: "Inferno é o momento em que se perde a liberdade de decidir (...) Um dia o Zé me falou "Veja a Fulana de Tal, está tudo tão certo, ela está fazendo os papéis, ela está namorando com não sei quem..." Ele me mostrou uma pessoa fazendo muito melhor do que eu, no sentido de conseguir organizar a vida pessoal com a vida no teatro, de ter alguém com quem estava trabalhando e ao mesmo tempo estava transando, uma coisa idealizada. Isso me marcou, mas era o caminho dela, não o meu."

Cada um no seu discernimento íntimo, com sorte, sabe distinguir as pedras do caminho alquímico, ocultas sob a superfície da água agitada na travessia dos ensaios ou da vida. Mas esse discernimento se equilibra sobre uma sensibilidade delicada:

PASCOAL DA CONCEIÇÃO: “o Zé queria encenar a Lulu, do Wedekind, em cima da morte do Luis. E eu tinha que matar o Marcelo. Aí, num determinado momento, eu comecei a entrar numas e a achar que eu que tinha matado o Luis. E pior, que eles sabiam que eu tinha matado o Luis, e que aquilo tudo era uma armadilha pra mim. No meio do ensaio. (...) eu comecei a achar "porra, vou me foder! o que tá acontecendo?!" Aí, comecei a cair em paranóia, e comecei a sofrer com isso. Sofrer muito. Mas muito muito mesmo. Eu me senti um assassino. Eu considero aquilo um surto. Um surto de pensamentos que eu não tinha controle. Eu tava com medo, um medo gigantesco tomou conta de mim, uma coisa apavorante. Meu coração ficava apertado, aturdido. (...) Até que foi passando, os dias foram passando, aí passou. Aí eu voltei pro teatro, não fiz a peça, não fiz o que era pra fazer e tudo mais. Foi um sofrimento. Passei um perrengue mesmo. (...) uma coisa triste, acho que é loucura, talvez. Quanto mais você mexe, mais você se aprofunda e passa a achar que aquilo é aquilo mesmo. 
Com certeza, foi um caso do que Fauzi chamou de "perigos implícitos ao paralelismo entre encenação e vida".

\begin{abstract}
"O ator é um soldado da alquimia possível da personalidade. O louco, de certa forma, percorre uma via paralela, mas se perde no caminho. Ele adivinha a entrada, mas nao sabe para onde ir, e, pior, logo não sabe mais como sair. O papel alquímico da arte e a potencialidade que encerra de autotransformação me parecem estar associados a sua própria essência. Para es que adotam esse principio, ele se torna o cinto de segurança e proteção contra qualquer tipo de vaidade e descaminho possível.” (ARAP, 1998, p. 236)
\end{abstract}

Cinto de segurança para os pilotos, e para os trapezistas da cena desconhecida uma rede tecida com as cordas elásticas e inquebráveis de procedimentos espontâneos cultivados ao longo dos anos, regimentos internos, explícitos ou não, forjados na inspiração ou na suspeita dessa dimensão alquímica:

\begin{abstract}
CAMILA MOTA: "A peça tinha um coro muito cabaço, contracenando com a Bete Coelho, que, na época, teve uma resistência muito grande ao nosso coro. E isso era ótimo, porque fazia parte da dramaturgia da Cacilda 1, o segundo ato era justamente a parte da Cacilda que não existiu, $A$ Gaivota, que o Zé chama ela pra fazer com o coro do Oficina, com o Samuca fazendo o Treplev e a Silvinha fazendo a Nina. Então era a Cacilda contracenando com o coro de Roda Viva, que foi uma mudança de geração. Cacilda e Walmor diziam "eles não sabem falar, não sabem vestir um figurino, não sabem andar, mas o teatro deles está sempre cheio." Então deu uma crise naquele tipo de companhia, da Cacilda, e o segundo ato de Cacilda 1 - que é o fim de tudo que o Zé escreveu - porque a Cacilda lé o começo e o fim da dramaturgia, ele juntou, e as outras peças são o meio - é Arcadina fascinada mas ao mesmo tempo resistindo àqueles jovens doidos, atores sem técnica, que não sabem fazer nada mas tem uma potência naquele nada. E isso foi interessante pra Cacilda 1, a crise da Bete com a gente e da gente com a Bete, porque compunha a dramaturgia. Nesse sentido, o Zé criou a situação pra dramaturgia, bancou a situação. A Bete [dizia] "tem que ter atores melhores nesse coro, esse coro é muito ruim", e o Zé: "Não. Eu quero esse coro!" Porque a dramaturgia ficava muito mais forte com aquele conflito, da diva, a Bete Coelho, uma puta atriz, com um coro totalmente cabaço que não sabia nada, mas que tinha uma gana e um desejo gigantesco."
\end{abstract}

Fauzi se declara um aprendiz de feiticeiro lidando com energias que movem a realidade através de efeitos colaterais não causais da cena, sem ter ideia de como lidar com isso. Talvez a dinâmica que Camila descreve seja um jeito de lidar com isso. Um passo na direção da integração de um poder. De administrar as dinâmicas inconscientes identificadas entre as pessoas, entre os eventos ou o que fosse, para favorecer a expressão de uma verdade poética. Seria possível lidar com o fenômeno e aplicar sua potência também na vida, como na cena?

As respostas são mais contundentes quando se fala em termos do efeito pretendido para as encenações, quando se parece considerar, para além da presença do público, o âmbito macrocósmico, do que a obra quer dizer para o mundo: 
CAMILA MOTA - Como um vodu, uma peça, agora a gente tá fazendo Bacantes. Porque a gente sacou que é uma hora boa de fazer, é necessário fazer Bacantes, porque está cheio de Penteu, e Penteu é o protagonista do mundo atualmente. Em vários lugares, todo mundo quer fazer papel de Penteu, muita gente fazendo esse papel. E aí que era importante ter cenas como Bacantes estraçalhando touros, Bacantes estraçalhando Penteu. Isso é um vodu importante. Então ele é mais pensado como objetivo, talvez, como um vodu, numa questão macro. Agora, pra que isso aconteça, a gente sabe que todo mundo que faz a peça, de alguma maneira, vai ter que se deparar com isso, vai ter que estraçalhar o seu próprio Penteu. Vai ter que viver, de alguma forma, essa questão. Pode ser um choque viver essa questão, pode não ser um choque. Você pode estar bem pra passar por isso, ou pode não estar bem, depende de cada um. Mas, como questão, eu acho que ela é mais colocada no macro.

\title{
MANDINGA DO BIXIGA
}

Os artistas parecem concordar que a maior façanha do Oficina é a própria sobrevivência de um teatro com esta história, seis décadas de (in)coerência paradoxal com um discurso complexo e consistente que basicamente reivindica e propaga liberdade e poesia. Como alguém falou no Simpósio, o Teatro Oficina funciona como uma acupuntura fincada no centro de São Paulo. Entre episódios brancaleônicos e outros de conquistas artísticas monumentais, os artistas chamam atenção para o paralelismo em relação à história do Oficina, nessa transformação constante do prédio, que se materializa como uma metáfora paralela a vários outros embates políticos e históricos.

\begin{abstract}
MARCELO DRUMMOND - "É a história acontecendo. Se acompanhar, vai ver que parece a história do Brasil. E é uma feitiçaria que se faz conscientemente. O Zé acha isso também. Porque o teatro Oficina foi construído com teatro. Tudo bem, o MINC colocou dinheiro, a Secretaria de Estado colocou dinheiro, o Zé colocou dinheiro, eu coloquei dinheiro, todo mundo, Caterine colocou dinheiro. Mas nesses 5 anos que eu fiquei quando eu cheguei em São Paulo, o teatro estava levantando as primeiras colunas que seguram o teto. Aí parou meses. O que a gente fazia? Uma coisa de teatro, uma cena. Uma maquete de uma cena do que a gente ia fazer. De Sertões, de Bacantes... Aí, tá, o teatro andava mais um pouquinho. Como uma macumba. Como um ebó de teatro. Uma coisa assim como no Candomblé, quando está tudo muito parado, o Pai de Santo vai lá e passa um ebó em você pra dar uma limpada e o negócio andar. Pra sua vida andar. Acende uma vela pra um anjo da guarda. No teatro, é o teatro. É fazer uma cena. Aí, o teatro andava mais um pouco. Aí parava. Aí tinha que fazer mais alguma coisa, a gente criava e fazia um evento. Então, o teatro, ele foi construído com o teatro. Nesse sentido. Com a mágica do teatro. Não com dinheiro. Ele é construído assim: o teatro que faz o teatro. No sentido mágico mesmo. O rito faz andar mais um pouquinho, aí para. É o embate que se vive até hoje no Brasil, e que revive agora no golpe."
\end{abstract}

O teatro fazendo o teatro. E vice versa. O teatro comprando prédio, driblando grandes corporações, barrando desastres urbanos. Mas quem faz o teatro?

PASCOAL DA CONCEIÇÃO: "Mesmo macumba você precisa do frango, precisa da vela preta, das flores, da água... Mas não era nada nesse sentido. Se tiver que ser religioso, tem que ser do ponto de vista do teatro. Se tiver que ser uma macumba, tem que ser do ponto de vista do teatro. Senão não, não reverte pro teatro. Óbvio! 
A experiência de Fauzi passa por uma prova da eficácia dessa dinâmica no episódio de sua primeira direção teatral, quando ele encontra na literatura de Clarice Lispector a compreensão libertadora dos processos psicológicos que atravessava, mas para uma assimilação completa e propriamente fértil dessa compreensão, precisou transformar as palavras da escritora em teatro.

PASCOAL DA CONCEIÇÃO: "O Zé falava assim: o teatro vai ser isso, vai ter não sei o quê... (...) ele deu continuidade, não ficou na punheta, foi em frente. Ia todo dia, reclamava, buscava, comprava areia, teve todo um trabalho. Tudo foi muito materializado. Por exemplo, sei lá, um dia, a gente sonhou fazer o teatro do Dioniso, tem fogo, tem água, tem céu, e não sei o que lá. Tá materializado. Tá na matéria, não tá só na abstração. Tá materializado. Vai lá, você vê tudo aquilo que estava pensado, organizado. Por exemplo, o dia em que o dono do prédio mandou uma carta: vou vender o teatro, se quiserem comprar, custa tanto. Aí o Zé falou assim: se a gente quer comprar o teatro, a gente quer. Mas não tem dinheiro. Então vamos buscar o dinheiro onde tem dinheiro. Aí chegamos lá no Banco Central, todo mundo cantando, dançando, tira a roupa e tal... Aí o Zé começa uma conversa que eu só vou entender agora. Na época eu não entendi nada. Era uma conversa mágica: "Nós viemos buscar o dinheiro pra comprar o Teatro Oficina." Aí o cara, que era o Edmar Bacha, falou: "você tem que dar uma hipoteca". Foi uma conversa toda misturada, mas o resumo era esse. O Zé falou "Nós temos uma hipoteca, a história do Oficina. E queremos comprar com isso." Aí o cara falou "Mas isso não vale dinheiro." E o Zé falou: "Mas o Silvio Santos vende carnê do Baú da Felicidade e pode comprar o Teatro, nós que fazemos o Teatro e amamos o Teatro, não podemos comprar o Teatro? Como assim? Que economia você quer pra o seu país? Que economia você quer pra sua economia? Que economia é essa que não valoriza isso? É uma economia do quê? De dinheiro por dinheiro? Mas dá em quê? Vai construir o que? Nós queremos construir um teatro no Bixiga!

Ao que parece, a cena ilustra bem o que seria uma operação bem sucedida nos moldes da citada "cosmopolítica": o uso do encantamento para a conquista de objetivos alinhados ao propósito de integração da dimensão poética da vida.

PASCHOAL DA CONCEIÇÃO: "Isso é uma conversa que tem muito de abstração, correto? Mas ela se realizou. Quando ela se realiza, ela tira do campo da loucura, vamos dizer assim. Dessa loucura entre aspas, do que é louco, tem que amarrar e tá babando, mas não é louco, é sensato. Tem uma lógica. (...) É loucura, mas tem um método. Que tá centrado onde? Na dedicação ao teatro, no estudo do que é fazer uma peça de teatro, na vontade de continuar fazendo teatro, no amor pelo teatro, pela poesia. No amor pela poesia de uma maneira que você fala assim "a poesia vai me salvar dessa coisa aqui, vai ser difícil mas ela vai me salvar. (...) O teatro está construído, a matéria teatral tá lá, pronta, o prédio tá lá e tá feito. Não há como negar. Então a poesia virou poesia concreta.

Ressoa a pergunta de Nietzsche na introdução tardia para seu Nascimento da Tragédia:

"Se fosse justamente a loucura, para empregar uma palavra de Platão, que tivesse trazido as maiores bênçãos sobre a Hélade?”

\section{LOUCO SÃO}


Nem todos escapam da loucura. Com 6 décadas na batalha, o Oficina tem seus mártires, como Samuca, Samuel Costa Junior, o corifeu primordial do Oficina na montagem de Roda Viva, de Chico Buarque, e Galileu, de Brecht, em 1968, visto como o ator ideal para a nova linguagem que se propunha, encarnando o ideal de uma vida no limiar da sensibilidade infinita e indistinta do inconsciente. Zé Celso escreve numa postagem em seu blog em 20/06/2014:

\begin{abstract}
"Grandes Artistas como Samuca, Corifeu do Coro de "Roda Viva", não puderam mais, depois do AÍ 5, atuar com a liberdade e invenção que traziam pro Teat(r)o no Brasil. (...) Os q mais talentosamente criaram a Arte da Atuação ao Vivo com o Publico Atuador, também foram sacrificados. Não suportaram o Recuo do Teatro Brazyleiro aos Palcos Italianos.” (ZÉ CELSO, 2014, blogdozecelso.wordpress.com)
\end{abstract}

Fauzi também suspeitava de um poder catalizador na loucura: "O psicodrama nos ensina que cada louco e cada marginal encarnam, como protagonistas emergentes, toda uma problemática social (...) Parece que o significado da palavra protagonista é esse mesmo, louco ou possesso." (ARAP, 1998, p. 237) E o trânsito das ideias sugere que o mais interessante talvez seja não curar, nem resolver o problema, mas integrar a loucura.

\begin{abstract}
PASCOAL DA CONCEIÇÃO - "Outro dia mesmo, o Zé foi lá, o grupo Sílvio Santos chamou uma reunião e disseram: "nós vamos dar a saída do teatro, na frente e atrás, e vocês liberam pra gente construir o que a gente quiser." O Zé falou: "Não. Agora a gente quer fazer aqui a Universidade Antropofágica, nesse terreno." E o cara: "mas esse terreno é nosso." E o Zé: "Não, o terreno é da humanidade. Essa terra, a Terra é da humanidade, não é de um nem de outro, acham que é, mas não é. O que a humanidade decidir que vai ser construído aí, ela vai construir." E é verdade. A humanidade, às vezes, decide coisas. As coisas são feitas porque a humanidade quer que seja. E vai ser. E eu acho que o Zé consegue. Porque ele é humanista, é um cara que estuda isso. E talvez aí ele tenha ligação com a Luz e com o caminho que o Fauzi fala. Eu acho que o Zé tem conexão humana com os desejos da humanidade. Ele pensa sobre isso, ele conversa sobre isso, o que a humanidade deseja, o que a humanidade quer, o que a humanidade tá atrás, pra onde ela quer avançar. A humanidade quer ficar parada no medo? com medo das coisas, medo do dia a dia, medo de morrer, medo da fome? Não, ela não quer. Então eu vou trabalhar mais que isso. Vou ser um parceiro da luta da humanidade contra essas coisas. Contra esse tipo de situação. Vou ser parceiro. Sei lá, no caso, da natureza. Você vê a natureza: a natureza quer deixar de ser verde, deixar de chover, deixar de cair água? Não, não quer. Então vamos ser parceiros da natureza."
\end{abstract}

Fauzi fala na ideia de que tudo na vida é simbólico, como um psicodrama cósmico. Uma ideia tão estranhamente plausível quanto flerta abertamente com a loucura. Mas talvez uma loucura pilotada, integrada. Que não deixaria de ser loucura, mas seria poder disponível à consciência. Uma vida condicionada ao simbolismo de tudo, o tempo todo a vista de todo terror e toda maravilha da existência, seria realmente uma "coisa de louco". Mas ainda um 
desafio instigante pela promessa de se poder viver conscientemente o paradoxo, segurando a chave de alguma alquimia.

Em que medida esta consciência, no grau de cada um, é a consciência dos artistas envolvidos com o grupo num momento dado, ou a consciência de uma entidade autônoma chamada Teatro Oficina? Entidade formada pelas contribuições de todas as consciências que fizeram a história do grupo, história feita de escolhas e decisões tomadas em picos de inspiração poética. Cada uma delas firmando mais um tijolo nas paredes de uma catedral em forma de consciência coletiva, algo similar aos que os hindus chamam de "egrégora". Haveria algo assim, um "paradigma”, ou um estado de espírito que anima este coletivo?

Talvez, a julgar por conversas ouvidas no Simpósio, sobre o coro do Oficina da montagem de Bacantes em 2016, por exemplo, que não teve tempo de crescer no sentido de ganhar essa consciência, porque as pessoas tinham acabado de chegar, muitos dois meses antes. Mesmo assim, elas conseguem entrar em cena com a potência necessária e fazer a alquimia. Certamente porque o coletivo tem um núcleo forte, pessoas experimentadas fazendo a corrente principal que ajuda todo mundo a entrar na vibração, ou, em outras palavras, absorver essa consciência.

LUCIANA DOMSCHKE: “eu não sei, mas eu estou perto de quem sabe, e parece que vem. Essa capacidade eu acho interessante. Não precisa ter estudado e tal, mas sei lá, ficar ávido por isso, que você pega. E isso acontece através da música, através da dança, através de gestos, da convivência, de gestos que não são cotidianos.

A atriz lembra da experiência de chegar a uma semana da estréia de uma peça de 5 horas só com uma hora encenada, e em poucos dias levantar todo resto e estrear, inteira e linda. E remete as palavras da grande autora, com Edson Elito, da atual sede do Oficina:

LINA BO BARDI - “O tempo linear é uma invenção do Ocidente, o tempo não é linear, é um maravilhoso emaranhado onde, a qualquer instante, podem ser escolhidos pontos e inventadas soluções, sem começo nem fim."

LUCIANA DOMSCHKE: “É a questão do código genético. Num terço da peça já tem desenvolvido um código genético daquela peça, e aí, não é mágica, põe o nome que quiser, mas é um ciclo. 9 meses gestando, chega uma hora, bum! Estoura a bolsa, nasce! (...) Essa experiência acaba desenvolvendo uma certa coragem, um certo despreendimento, mas à partir de uma disciplina que te liberta.

Teria o coletivo desenvolvido uma espécie de "código genético" que se fortalece com o tempo, com a prática, se estabilizando a cada ensaio, a cada espetáculo, capaz de "imantar" as consciências de seus artistas? Por extensão, também do público? Uma rede de segurança feita com as cordas elásticas dos procedimentos cultivados no tempo, uma trama de 
regimentos voláteis e silenciosos forjados na inspiração pura. A expansão dessa inspiração seria uma grande alquimia. Expandir a rede para o público, pela poesia e pela força vital do teatro, espalhando mentalidade libertária cultivada em carne e osso em ação no tempo e espaço. Não seria esse o ouro desejado?

PASCOAL DA CONCEIÇÃO: "até um ato meio louco de subir numa árvore pra evitar que ela seja cortada, é louco mas não é louco. É louco numas. É louco pra uma determinada linguagem, uma maneira de ver a vida. Mas para uma outra maneira é absolutamente correto, só podia ser assim. Tem que ser assim. Óbvio. E depois o cotidiano, o dia a dia, vão provando que é assim mesmo. Nesse sentido, a construção do Teatro Oficina, a realização de Bacantes, a realização dos Sertões, essas coisas que o Zé insiste, essa obsessão de fazer tudo isso, é uma coisa que vai desafogando o coração da gente, da ansiedade de achar que isso não é possível. Que não dá. Porque dá, sim, quando você é aliado da humanidade, por mais difícil que as coisas sejam, você consegue avançar e ganhar poesia.

O teatro é um caminho. O caminho é um labirinto. O labirinto é o destino. O destino é a liberdade. A liberdade é uma oficina alquímica que mantém viva a poesia impossível. 


\section{Capítulo 4}

\section{TEATRO NUVEM}

A influência da experiência lisérgica no teatro entra nesse estudo dialogando com a importância central que o artista dá a essa questão em seu depoimento. Buscando honrar, inclusive, a ousadia que teve de se expor, assumindo a ligação de suas escolhas e perspectivas com a experiência lisérgica, escrevendo, ainda, para a mesma sociedade por quem foi um dia condenado pela mesma experiência. Num escândalo natural, cravado em nosso DNA, porque toca o Inconsciente Coletivo em seu extinto de auto-preservação. Mas que pode ser observado independentemente do sistema moral em relação ao uso de substâncias ilícitas e potencialmente perigosas. Não faria sentido relativizar o mérito ou a singularidade de uma obra por incluir em sua gênese a experiência lisérgica. Seria o mesmo que desprezar as leis de Newton porque a maçã caiu na cabeça dele. O livro "Freud e a Cocaína" (Cohen, David, 2014) conta que o pai da psicanálise usou a substância em pesquisas e tratamentos nos primeiros anos de prática, mas uma mudança da opinião médica em relação à droga o levou a destruir os registros destes estudos. Talvez para não comprometer a credibilidade de suas teorias inovadoras, que ele sabia que seriam desafiadas. Para resguardar sua pesquisa e poder escrever "A interpretação dos Sonhos" em paz, ele destruiu as provas. Precisava do segredo para ser levado à sério?

É uma situação que Fauzi conheceu bem, mas encarou de modo diferente. Como a personalidade das substâncias: uma que prende numa euforia mental, outra que liberta a percepção do infinito. Ambas de profundo impacto na alma humana. Tanto, que o contato com a substância detonou em Fauzi a mesma paixão pelos estudos da mente. Mas por uma escolha sintomática, mesmo trabalhosamente conquistada, seu legado resultou estritamente artístico. Sua solução para o choque de consciência causado pelo encontro com uma substância perturbadora foi literalmente dionisíaca, no sentido mitológico. Para além da intensidade, do tamanho da dose e do pioneirismo do uso, a dimensão especificamente teatral da experiência de Fauzi com o LSD talvez se verifique numa possível associação entre esse tipo de experiência e a própria natureza ancestral do teatro. 
Para isso, recorremos ao livro The Road to Eleusis, Unveiling the Secrets of the Mysteries (A Estrada para Eleusis, Desvendando os Segredos dos Mistérios), especialmente o artigo intitulado Resolvendo o Mistério Eleusino, em que o trabalho do historiador Carl A. P. Ruck sugere uma ligação primordial entre o Teatro e o uso de alucinógenos através do mito de Dioniso, o deus grego cujos ritos compõem a origem desta arte. O livro surgiu para esta investigação ao ser citado como influência determinante na obra do diretor e dramaturgo José Celso Martinez Corrêa, em relação ao vínculo entre teatro e alucinógenos. Na entrevista que integra esta pesquisa, o diretor confirmou ter lido o livro, mas não entrou em detalhes, talvez guardando a herança de uma sabedoria que se revela nessa estrada para Eleusis.

\section{O DRINK DA DEUSA}

A Estrada para Eleusis examina os Mistérios de Eleusis, rituais celebrados por quase dois milênios desde a origem da civilização grega, numa vila vizinha à Atenas. Eram acontecimentos anuais, atendidos por peregrinos de toda Gécia, centrado no mito de Deméter, a deusa da terra cultivada, e de sua filha com o irmão Zeus, Perséfone, deusa das ervas, flores, frutos e perfumes. Segundo Ruck, no cortejo ritualístico que se formava no caminho até Eleusis por ocasião dos Mistérios:

\footnotetext{
Os peregrinos chamavam Iaco enquanto caminhavam. Era ele que consideravam guiar seu caminho (...) Quando finalmente chegavam a Elêusis, dançavam até tarde da noite (...) em homenagem às duas deusas sagradas e seu misterioso consorte Dioniso, o deus dos inebriantes (WASSON, HOFFMAN, RUCK, 1978, p.12)
}

Iaco, segundo o mitólogo Junito Brandão, era o "avatar eleusino de Dioniso" (BRANDÃO, 1986, p.299). E sua presença nos Mistérios de Eleusis remonta às religiões dos povos agrários que precederam os gregos, centradas na fertilidade da mulher e no ciclo de morte e renascimento da natureza. Segundo Ruck, nessas religiões, a mulher era a Grande Mãe e o mundo inteiro seu filho, e o evento essencial era o Matrimônio Sagrado, no qual a sacerdotisa comungava periodicamente com o reino dos espíritos da terra para renovar o ano agrícola e a vida civilizada. E o noivo da deusa era um espírito vegetal que a raptava para dentro da terra, o reino da fertilidade, onde ele a possuía; ao mesmo tempo, era também o fruto que depois crescia da terra. Os Mistérios de Eleusis seriam a variante definitiva desse Matrimônio Sagrado, eternizado no mito de Deméter: 
foi como Dioniso que o Zeus assimilado como consorte da Deusa Mãe sobreviveu ao período clássico. Seu nome o designa como o Zeus de Nysa, pois Dios é uma forma da palavra Zeus. Nysa (...) era o nome de todo lugar onde era firmado o mesmo casamento envolvendo a paixão da morte e renascimento de Dioniso. Quando ele possuía suas mulheres devotas, as mênades ou bacantes, ele era o mesmo que Hades, o senhor da morte e noivo da deusa Perséfone. (WASSON, HOFFMAN, RUCK, 1978, p.14)

Talvez tenha alguma coisa a ver a ideia de Dioniso ser ao mesmo tempo Zeus, o senhor do Cosmos, e Hades, o senhor dos mortos - ou dos espíritos, que lembra a trindade cristã do Pai, Filho e Espirito Santo, e também as últimas palavras de Pano de Boca: "a voz do silêncio... OM TAT SAT". Ou ainda as três fases da alquimia vividas por Fauzi, Nigredo, Albedo, Rubedo: a morte, o êxtase, e a vida. Mas o historiador e o mitólogo falam de outra coisa. Discordam sobre a origem desse nome. Para Brandão "Dioniso, em grego Diónysos, é palavra ainda sem etimologia." (BRANDÃO, 1987, p.113) Mas ele confirma a abrangência do nome Nysa: "faz parte da geografia mítica: os mitógrafos, além de Tebas, Naxos, Trácia..., localizavam Nisa desde o Cáucaso à Arábia, e do Egito à Líbia” (IDEM). Não caberia aqui um estudo detalhado dos mitologemas relacionados, seria um estudo à parte, só observamos o simbolismo geral e a própria história do mito Dioniso, numa reflexão inspirada pelo texto de Ruck, em relação ao depoimento de Fauzi.

O mito das deusas que fundamenta os Mistérios está registrado num poema anônimo do século VII a.C., chamado hino homérico a Deméter, que narra como Perséfone foi raptada por Hades, o senhor dos mortos, quando colhia flores em Nysa e escolheu um narciso de cem cabeças, flor de significado simbólico específico:

\begin{abstract}
os próprios gregos, no entanto, achavam que os narkissos eram assim chamados por causa de suas propriedades narcóticas, obviamente porque essa era a natureza essencial ou o simbolismo da flor de Perséfone. O rapto conjugal ou a captura de donzelas enquanto colhem flores é, além disso, um tema comum nos mitos gregos, e Platão registra uma versão racionalizada da história em que o companheiro da donzela raptada se chama Pharmaceia, nome que significa o "uso de drogas". O mito particular que Platão racionaliza, na verdade, define o sacerdócio em Elêusis. Não pode haver dúvida de que o sequestro de Perséfone foi uma convulsão induzida por drogas. (WASSON, HOFFMAN, RUCK, 1978, p.13 - )
\end{abstract}

Não existem relatos objetivos sobre o que, de fato, acontecia durante os Mistérios de Eleusis, chamados mistérios (também) por ser absolutamente proibido, sob pena de morte, que se revelasse o que acontecia no Telesterion, o salão da iniciação, dentro do santuário. Mas, segundo Ruck, vários textos antigos contam o que era permitido contar, alguns até um pouco mais, e o conjunto das informações sugere possibilidades interessantes. Algo que se sabe com certeza é que a "experiência era uma visão em que o peregrino se tornava alguém que viu, um epoptes" (IDEM). O que pode sugerir algum tipo de espetáculo visual, algo teatral, especialmente considerando ser Dioniso, o deus do Teatro, o consorte divino da Grande Mãe. Porém, pelo que se sabe hoje, parece que não era o caso: 
o salão, que hoje pôde ser reconstruído a partir de vestígios arqueológicos, era totalmente inadequado para apresentações teatrais; tampouco os livros contábeis do santuário (...) registram quaisquer despesas para atores ou cenógrafos. (...) Os gregos eram sofisticados em relação ao drama, é altamente improvável que fossem enganados por qualquer tipo de truque teatral, especialmente sendo pessoas inteligentes como o poeta Píndaro e o trágico Sófocles que testemunhavam o valor avassalador do que se via em Elêusis. Além disso, haviam sintomas físicos que acompanhavam a visão: medo e tremor nos membros, vertigem, náusea e suor frio. (...) reações sintomáticas não a um drama ou a uma cerimônia, mas a uma visão mística; e uma vez que a visão poderia ser oferecida a milhares de iniciados a cada ano de maneira confiável, parece óbvio que um alucinógeno deve tê-la induzido. (WASSON, HOFFMAN, RUCK, 1978, p.13)

A convicção dos autores encontra raiz no próprio mito de Demeter e Perséfone. Além do simbolismo da viagem ao mundo dos mortos, ligado aos estados alterados de consciência pelas tradições xamânicas, o mito narra como a deusa chega em Eleusis em busca da filha desaparecida e pede aos anfitriões que lhe prepararem uma certa bebida, chamada Kykeon "Trata-se, ao que parece, de uma bebida mágica, cujos efeitos não se conhecem bem” (BRANDÃO, 1986, p.291). Mas essa convicção também se baseia em estudos etnobotânicos que sugerem que o ingrediente alucinógeno do Kykeon seria o conhecido "esporão de centeio", cientificamente chamado "Claviceps Purpúrea", um fungo que ataca o centeio (um dos cereais cultivados na região de Eleusis) e do qual se extraem vários alcalóides e substâncias medicinais, inclusive o LSD25. E se baseia ainda em outros indícios históricos, como uma comédia do século V a.C., "Os Demos" (“Os Burgos”) escrita por Eupolis logo após um escândalo ocorrido quando aristocratas atenienses começaram a celebrar os Mistérios em casa com grupos de convidados. Segundo Ruck, na peça, alguém denuncia a um juiz a profanação dos Mistérios dizendo que o acusado tinha grumos de centeio no bigode e o tinha subornado "para dizer que era simplesmente mingau e não a poção que ele havia bebido. Por um possível trocadilho, o comediante sugere que os "grumos de centeio" incriminadores eram “púrpuras de centeio”. (WASSON, HOFFMAN, RUCK, 1978, p.13).

Se aceitamos essa hipótese, do Kykeon ser uma bebida lisérgica, reconhecemos os sinais de uma ligação primordial do chamado Deus do Teatro à substância que transformou a vida do autor do Mare Nostrum, talvez se conectando diretamente ao cerne mais ancestral da verve criativa que determina sua vida, a paixão pelo mesmo teatro. Uma ligação que parece ser apenas parte de uma influência sistêmica.

\section{EVOÉ BACO!}


Se o Kykeon era uma bebida lisérgica, e se não era teatro o que se via nos Mistérios de Eleusis, a ligação primordial entre o Teatro e o uso de alucinógenos começa a se delinear quando se observa a presença exclusiva de Dioniso nos ritos, como guia dos peregrinos e como consorte das deusas, especialmente considerando as datas:

\begin{abstract}
Elêusis deve ter sido colonizada entre 1580 e 1500 a.C, mas o primeiro santuário (...) foi construído no século XV a.C. e, nesse mesmo século, se inauguraram os Mistérios. Foram vinte séculos de glória. Nos fins do século IV d.C, Teodósio, o Grande (346-395 p.C.), fechou por decreto e destruiu a picareta os templos pagãos. Era o fim do paganismo, no papel, porque, sobre as ruínas de seus templos Zeus, Deméter e Dioniso ainda reinaram por muito tempo. (BRANDÃO, 1986, p.296)
\end{abstract}

Considerando os primeiros registros do teatro grego no século VII a.C., no início do chamado Período Clássico, quase mil anos depois de celebrados os primeiros Mistérios de Eleusis, cabe especular se Dioniso, ao longo de todo esse tempo, já era o deus do Teatro, já que o Teatro, como conhecemos através dos textos clássicos, provavelmente ainda não existia. Mas ele, o deus, segundo Junito Brandão, já era cultuado pelos gregos "desde o século XIV ou XIII a.C” (BRANDÃO, 1987, p.117) como indica sua presença em Eleusis. E considerando que o teatro grego surgiu e floresceu principalmente em Atenas, cidade vizinha à Eleusis onde se preparavam e para onde voltavam ou por onde passavam, provavelmente na ida e na volta, todos os peregrinos que participavam dos Mistérios, parece provável que a experiência em Eleusis tenha inspirado, ao longo dos séculos, através da presença daquele que se tornou o deus do teatro, o surgimento e florescimento desta arte. Como essa inspiração se transformou numa forma tão sofisticada de arte, podemos especular. Apesar de estar presente na Hélade desde o século XIV, o mito Dioniso:

\footnotetext{
só se manifesta, e de forma aparentemente grotesca, no século IX, e só a partir dos fins do século VII a.C. tem sua entrada solene na mitologia e na literatura (...) sobretudo [devido à] a causas políticas (...): Dioniso é um deus humilde, um deus da vegetação, um deus dos Campônios. Com seu êxtase e entusiasmo, o filho de Sêmele era uma séria ameaça à pólis aristrocrática (...) cujo suporte religioso eram os aristocratas deuses olímpicos. (BRANDÃO, 1987, p.117)
}

A verve subversiva do deus do teatro vive ainda hoje numa fogueira xamânica queimando no centro da arte que ele fundou, e seus reflexos na vida dos envolvidos são inevitáveis para sensibilidades extremas. Um risco necessário para a liberdade. Desde sempre, desde que a Iniciação nos Mistérios era livre, aberta e frequentada por todas as classes sociais “imperadores e prostitutas, escravos e homens livres" (WASSON, HOFFMAN, RUCK, 1978, p.13). 
ao alvorecer, uma enorme procissão partia de Atenas. Iniciados, neófitos e um grande público acompanhavam as sacerdotisas que reconduziam a Elêusis os hierá, os objetos sagrados (...) Encabeçando a alegre e barulhenta procissão, ia um carro com a estátua de Iaco, com seu respectivo sacerdote, entre exclamações entusiastas de (Íakkhe, ó Ílakkhe), "Iaco, ó Iaco!" (...) o avatar eleusínio de Dioniso (...) Ao cair da tarde, a procissão atravessava uma ponte ( $ү \dot{\varphi} \varphi \cup \rho \alpha$ ), sobre o rio Cefiso, e alguns mascarados diziam os piores insultos contra as autoridades, contra pessoas importantes de Atenas e contra os próprios Iniciados.” (BRANDÃO, 1987, p.299)

Chama atenção os traços em comum entre esta "alegre e barulhenta procissão" e as festas dionisíacas celebradas anualmente ao longo dos séculos. As mais arcaicas, Dionísias Rurais, tinham como "cerimônia central" um "kômos, quer dizer, no caso, uma alegre e barulhenta procissão com danças e cantos, em que se escoltava um enorme falo. Os participantes dessa ruidosa falofória cobriam o rosto com máscaras (BRANDÃO, 1987, p. 299). Nas Lenéias, já mais recentes mas ainda sobre as quais pouco se sabe:

\begin{abstract}
"Dioniso era invocado com o auxílio do daduco, "o condutor de tochas" (...) o sacerdote eleusino, "trazendo na mão uma tocha", exclamava: "Invocai o deus!" Os participantes do festival gritavam em resposta: "Ó Iaco, filho de Sêmele, distribuidor de riquezas!" (...) [e] se iniciavam por uma procissão de caráter orgiástico (...) a que se seguia um duplo concurso de comédia e tragédia. (BRANDÃO, 1987, p.299)
\end{abstract}

Nas Dionisías Urbanas, já no Período Clássico, o primeiro dia "era consagrado a uma majestosa procissão, de que a cidade inteira participava. Nessa procissão transportava-se a estátua do deus do Teatro" (IDEM) E a quarta grande festa dionisíaca, e a mais antiga, eram as Anthestéria, ou "festa das flores", que celebrava a primavera e parece ser uma versão ancestral do Carnaval, já que era celebrada "nos dias 11, 12 e 13 do mês Antestérion, fins de fevereiro, inícios de março" (IDEM, p.133), e durante a qual se praticava a "bebedeira sagrada", e se organizava:

\footnotetext{
"uma solene e ruidosa procissão (...) [em torno de] uma embarcação, que deslizava sobre quatro rodas de uma carroça, puxada por dois Sátiros. Na embarcação via-se o deus do êxtase, empunhando uma videira, ladeado por dois Sátiros nus, tocando flauta. Um touro, destinado ao sacrifício, acompanhava o barulhento cortejo, cujos componentes, provavelmente disfarçados em Sátiros e usando máscaras, cantavam e dançavam ao som da flauta. (...) as Antestérias eram a festa sagrada do vinho (...) os participantes dos festejos, sagradamente embriagados, começavam a cantar e a dançar freneticamente, não raro à noite, à luz dos archotes, ao som das flautas e dos címbalos, até cair semidesfalecidos. (BRANDÃO, 1987, p.
}

Se os Mistérios de Eleusis ocorreram desde o século XV a.C., e todas essas festas se desenvolveram ao longo dos séculos para alcançarem um apogeu no Período Clássico, no século V, faria sentido que a "alegre e barulhenta" procissão dos peregrinos guiada por Iaco (Dioniso) com os mascarados vociferantes fosse o modelo para as festas dionisíacas, como aliás, indica a presença nas Lenéias do daduco, o sacerdote eleusino "condutor de tochas". 
Aristóteles fala no desenvolvimento do teatro à partir das festas e dos coros em honra à Dioniso, com os cantores vestidos de sátiros, os Ditirambos, que deram origem a Tragédia, passando pelo Drama Satírico, “danças mímicas e rituais em honra de Dioniso [que] deram origem a representações rústicas [nas quais um] corifeu reproduzia alguma aventura de Dioniso" (BRANDÃO, 1987, p.129).

Vamos rever o mito para presentificar a natureza da operação. O mito de Dioniso começa no amor entre Zeus e Perséfone, que gera o primeiro Dioniso, então chamado Zagreu. Para proteger o filho dos ciúmes da deusa Hera, Zeus o confia aos cuidados de Apolo, que deixa a criança aos cuidados de 5 irmãos ferreiros e feiticeiros (alquimistas) os Curetes, que já tinham cuidado de Zeus quando sua mãe Reia o salvou da fome de Saturno. Mas Hera envia Titãs, que o sequestram e o cozinham em pedaços, e o devoram. Então Zeus fulmina os Titãs e de suas cinzas nasce a humanidade, que tem, no que resta de Dioniso nas cinzas dos Titãs, a origem do que há de bom em cada um de nós. No momento dos raios divinos, Deméter salva o coração da criança, ainda vivo. Ou, numa outra versão do mito, é Zeus quem engole o coração do filho, então fecunda Sêmele, avatar da Grande Mãe, que fica grávida do segundo Dioniso. Disfarçada de ama, Hera aconselha Sêmele a pedir a Zeus que se mostre em todo seu esplendor. Zeus tinha jurado pelo rio Estige, o rio da morte, jamais contrariar seus desejos, então se apresenta com seus raios e trovões. A princesa morre carbonizada, mas Zeus recolhe de seu ventre o fruto inacabado de seus amores e o acolhe em sua perna até completar a gestação. Então transforma o filho em bode e pede ao irmão Hermes que o leve até o monte Nisa, onde é "confiado aos cuidados das Ninfas e dos Sátiros" (BRANDÃO, 1987, Vol. II, p. 117)

Sabendo que o uso de um mito para expressar uma ideia se justifica exatamente quando esta ideia escapa a uma abordagem lógica, arriscamos uma interpretação do símbolo: a imagem sugere o duplo processamento de uma "força". Um processo que inclui o raio divino de Zeus, a perfeição artística de Apolo, a obscuridade dos Titãs e a generosidade da mãe terra Deméter, resulta na humanidade, o animal racional; no segundo processo se unem à essas forças o capricho feminino de Semele, a luz de Zeus e a companhia fluida, fértil, visceral e sensual das Ninfas e dos Sátiros, e resulta em algo além do humano, agora divino: o Teatro. A razão, a linguagem objetiva e lógica, têm que morrer para renascer na forma de uma outra linguagem, mais abrangente, e divina: a linguagem teatral. 
Se esta leitura reúne os elementos que estariam na gênese desta linguagem (o princípio criativo de Zeus, o princípio feminino e a fertilidade da Terra (Deméter, Perséfone e Sêmele), a perfeição luminosa de Apolo, a obscuridade dos Titãs e a visceralidade fluida e sensual das Ninfas e Sátiros), ainda não explica como isso tudo teria se combinado para formar a linguagem teatral. Mas aponta um caminho.

Anualmente, os sacerdotes de Deméter, Perséfone e Dioniso celebravam os Mistérios de Eleusis, com a experiência no Telestérion que incluiria o estado de consciência alterada provocado pelo Kykeon. Mas para os peregrinos que participavam, era algo bem mais extraordinário. Ao que parece, um iniciado se tornava um "epoptes" somente numa segunda experiência consecutiva, mas os mistérios eram considerados uma "experiência culminante de uma vida inteira (...) [e] o período de preparação e dos rituais preliminares (...) exigiria mais de meio ano de residência em Atenas" (WASSON, HOFFMAN, RUCK, 1978, p.12 - ). Ou seja, não era algo que se podia repetir à vontade. Considerando o impacto positivo que parecia exercer sobre todos, é plausível supor que os "iniciados" buscassem repetir ao menos uma parte da experiência. E nesse ponto, Dioniso parece ter tido um papel fundamental, por mais de uma razão. Por um lado, há a questão do êxtase, do maravilhamento experimentado em Eleusis, que seria ligado ao êxtase dionisíaco, mas não é o mesmo. No mito de Deméter que fundamenta os Mistérios, há um momento em que a deusa recusa uma taça de vinho que lhe é oferecida, e então pede para que lhe preparem o Kykeon. Ou seja, o mito determina que não é o álcool que será consumido em Eleusis. Ainda assim, é Dioniso o consorte das deusas. E talvez isso se explique a partir de algo que normalmente não se menciona sobre o vinho de Dioniso. Segundo Ruck, os gregos não conheciam a arte da destilação, portanto o teor alcoólico de seus vinhos não poderia exceder 14\%. Além disso, eles bebiam o vinho diluído em água, geralmente com pelo menos três partes de água. O que pode sugerir que eles bebiam algo só levemente inebriante. Porém, parece que não era o caso:

a palavra para embriaguez em grego designa um estado de delirante loucura. Ouvimos falar de vinhos tão fortes que (...) exigiam pelo menos oito partes de água para serem bebidos com segurança (...) beber certos vinhos diretamente causava danos cerebrais permanentes e, em alguns casos até a morte.(...) o álcool não poderia ter sido a causa dessas reações extremas. Também podemos documentar o fato de que diferentes vinhos foram capazes de induzir diferentes sintomas físicos, variando de sono a insônia e alucinações. A solução para essa aparente contradição é simplesmente que o vinho antigo, como o vinho da maioria dos povos primitivos, não continha álcool como único inebriante, mas era uma infusão variável de toxinas herbáceas em um líquido vínico. (...) os gregos inventaram um espectro de ingredientes para suas bebidas, cada um com suas próprias propriedades. (...) o vinho de Dioniso foi o 
principal meio pelo qual os gregos clássicos continuavam a participar do antigo êxtase residente em todas as formas vegetais que eram os filhos da Terra. Em situações sociais, o ato de beber era regulado por um líder, que determinava o grau de embriaguez que ele imporia aos presentes, que bebiam cerimonialmente numa sequência medida de brindes. Nos eventos sagrados, o vinho seria mais potente e o propósito expresso da bebida era induzir aquela embriaguez mais profunda na qual a presença da divindade poderia ser sentida. (WASSON, HOFFMAN, RUCK, 1978, p. 12 - )

Isso reforça o sentido da presença de Dioniso nos Mistérios de Eleusis. Se era ele o deus do êxtase e do enthusiasmós, palavra grega para inspiração divina, assim como o deus do vinho ou da substância que levava ao êxtase e entusiasmo, e se o Kykeon é um alucinógeno, faz sentido que fosse ele o guia dos iniciados no rumo de uma experiência descrita como análoga a um contato com a divindade.

No sentido oposto, sendo Dioniso também um deus da fertilidade que devia ser celebrado todo ano, é possível que os procedimentos da procissão para Eleusis, liderada por Iaco tenham sido mimetizados dessas várias formas, as quais acabaram por criar as condições para o surgimento da arte do Teatro. E isso talvez explique a forma, mas não a essência da relação entre Eleusis e o teatro. Que é a mesma essência da relação entre Eleusis e a experiência de Fauzi.

Se a presença de Dioniso em Eleusis, desde mil anos antes de tudo, com a evolução do mito e sua influência, contribuiu para a criação da forma de arte da qual ele se tornou um deus, é possível ainda supor uma influência, nessa gênese, especificamente do que se passava no Telesterion sob a influência do Kykeon: a experiência inefável.

\section{SILÊNCIO}

No século II d.C., o poeta Aristides de Mileto quase rompe o sagrado segredo de Eleusis ao escrever que o iniciado experimentava algo "novo, surpreendente, inacessível à cognição racional" (...) [e] segue falando das "visões inefáveis" que muitas gerações de homens e mulheres afortunados tiveram o privilégio de contemplar." (WASSON, HOFFMAN, RUCK, 1978, p.05 - ). Assim, todos aqueles iniciados saíam de Eleusis trazendo na alma essa experiência descrita como imensa e definitiva, de maravilha e assombro transformador, inspiradora porém incomunicável: não só era proibido contar, talvez até mesmo comentar entre os iniciados, como talvez eles não soubessem como, já que seria inútil tentar explicar o que lhes tinha acontecido. Inútil e potencialmente perigoso: 


\begin{abstract}
As leis de Atenas tornaram um crime falar sobre o que acontecia em Elêusis no Telesterion. Perto do fim do hino homérico a Deméter, esse silêncio é expressamente imposto a todos os iniciados. Em 415 a.C. houve uma avalanche de profanações deliberadas dos mistérios pelo jet-set Ateniense, seguida de uma repressão com punições severas. Mas o segredo estava muito além do alcance das leis de Atenas. Reinava em todo o mundo grego e nunca foi seriamente violado. Também era autoimposto. [Os iniciados] não se dispunham a discutir com estranhos o que lhes fora revelado: as palavras não podiam transmitir as maravilhas daquela noite, e sempre haveria o perigo de que o esforço para a explicação ser recebida com incredulidade, com o escárnio e a zombaria que pareceriam ao iniciado um sacrilégio, o feririam no âmago de seu ser. Alguém que conhece o inefável é relutante em embarcar em explicações: palavras são inúteis. (WASSON, HOFFMAN, RUCK, 1978, p.21 - )
\end{abstract}

Sabemos que a questão da inacessibilidade "à cognição racional", a inefabilidade da experiência, e do perigo da comunicação ou de sua tentativa ser mal interpretada, é também uma questão chave na trajetória de Fauzi:

\footnotetext{
“[eu] não suportava ter tido acesso a um segredo tão descomunal e incomunicável. (...) "o duelo que eu travava tinha a ver com a linguagem e com as palavras. Eu ainda não dispunha de informações que pudessem me ajudar a classificar e ordenar toda a experiência." (ARAP,1998, p.51/57)
}

$\mathrm{O}$ artista se refere à dificuldade em lidar com a nova perspectiva conquistada em sua terapia radical, perspectiva que incluía elementos contundentes para sua percepção, determinantes de todas as escolhas subsequentes, portanto algo urgente, mas ao mesmo tempo impossível de se compartilhar como informação objetiva. Na linguagem usual, nada faria sentido. Impossível ser usual, e impossível ser espontâneo sem causar escândalo pelo toque inadequado nas dimensões profundas do coletivo, sem a habilidade necessária para trespassar os limiares cuidadosamente preservados pelas convenções da normalidade. Provavelmente, os iniciados em Eleusis passariam por processos similares se não fosse essa lei do segredo. Lei que sugere um poder no silêncio, como se soubessem que a experiência não era história pra contar, mas se fosse bem guardada, daria bons frutos. E havia a cumplicidade do segredo compartilhado no silêncio. Segundo Ruck, algumas fontes falam de um "vínculo de aliança e amizade que surgia entre os iniciados (...) pelo compartilhamento de uma experiência sobrenatural inesquecível, um sentimento de confraria, de irmandade" (WASSON, HOFFMAN, RUCK, 1978, p.21 - ). Mas Fauzi estava praticamente sozinho na situação, não tinha uma irmandade para ser cúmplice, muito ao contrário. E diferente dos Iniciados em Eleusis, que viviam nos Mistérios experiências únicas, com as participações condicionadas a "meses de aprendizado e rituais [que] precediam a revelação na noite dos Mistérios” (WASSON, HOFFMAN, RUCK, 1978, p.19 - ), Fauzi não fez preparação alguma 
e tomou o que seria o Kykeon profano do século XX duas vezes por mês durante dois anos. E ele também não conhecia a lei do silêncio imposto por Deméter, nem intuiu seus fundamentos. Talvez o terapeuta tenha avisado ou recomendado discrição, mas não há registro de nada objetivo nesse sentido, apenas uma advertência posterior: "[ele] me perguntou se eu queria ser crucificado (...) não sei se sua pergunta pretendia me induzir a não me expor de forma tão atabalhoada, e talvez ele se visse pressionado pelos boatos que corriam sobre minha sanidade mental." (ARAP, 1998, p.55) Segundo o depoimento, no primeiro momento, foi impossível para Fauzi ficar quieto, surpreendido como um náufrago inconformado numa ilha de consciência que emergia inapelavelmente na superfície do Mare Nostrum. Depois, segundo o depoimento, ele parece ter aprendido por si a lei do segredo, ainda a tempo da experiência firmar raízes no silêncio para florescer na forma da sua arte. Assim como a experiência em Eleusis, de forma análoga, teria firmado raízes no silêncio do povo grego para florescer, inclusive, na forma da arte.

No terreiro dionisíaco, o teatro eclodiria à partir dessa impossibilidade do compartilhamento objetivo da experiência inefável. Seria um dos componentes fundamentais no processo que resultou na criação dessa forma de arte. Por milênios, a imensidão do assombro e da maravilha transformadora passava a viver no interior de cada iniciado, mas não caberia dentro de quem fosse, tinha que ser necessariamente compartilhada. Diante da proibição de se falar ou escrever objetivamente sobre isso, ela mesma, a maravilha assombrosa, encontrou seus próprios meios. E um desses meios em especial seria essa expressão cultural que se desenvolveu para ser o que hoje chamamos teatro. Nesse caso, importam duas coisas: como a busca da comunicação do incomunicável se torna teatro, e o que seria, afinal de contas, este conteúdo incomunicável?

\section{PENSAMENTO MÁSCARA}

Quando Fauzi descreve suas experiências alucinógenas com seu terapeuta, fala em imagens e "memórias editadas" por "um misterioso computador" interno, "mecanismos infinitamente sensíveis" com "vida inteligente", a partir dos quais "tudo se encadeava lindamente, oferecendo-se como material de estudo e autoconhecimento." (ARAP, 1998, p. 40). É preciso observar que esta descrição se refere a uma experiência controlada em função 
de seu objetivo definido de "estudo e autoconhecimento". As correntes religiosas místicas da Grécia antiga, como aquela ligada aos Mistérios de Eleusis, se orientavam por objetivos análogos, "sede de conhecimento contemplativo (gnôsis) [e da] purificação da vontade para receber o divino (kátharsis)” (BRANDÃO, 1987, vol II. p.125). Assim como as experiências de Fauzi foram empreendidas sob cuidados terapêuticos específicos que direcionavam o transe, é possível supor que a experiência em Eleusis também seria, de alguma forma, conduzida em função de seus objetivos específicos. Nesta forma de condução do transe estaria a chave para a gênese da linguagem teatral.

Essa condução seria mais no sentido oportunizar uma viagem coletiva coesa do que impor narrativas. Consoante a contraparte Dionisíaca do teatro que se mantém dominante mesmo com a evolução da arte depois que "a tragédia se tornou mais apolínea que dionisíaca. Despindo-se de Dioniso e revestindo-se da indumentária solar e patriarcal de Apolo, pôde ser tranqüilamente agasalhada como liturgia. (BRANDÃO, 1987, vol. II, p.128). Aquela contraparte que, na posse da palavra e da atenção do público, não dita regras, mas toca sensibilidades para gerar consciência e liberdade. No livro Mito e Religião na Grécia Antiga, Jean Pierre Vernant escreve:

\begin{abstract}
"Não havia em Elêusis nenhum ensinamento, nada que se assemelhasse a uma doutrina esotérica. Sobre isso, o testemunho de Aristóteles é decisivo: "Os que são iniciados não devem aprender algo, mas experimentar emoções e ser levados a certas disposições." Plutarco, por sua vez, evoca o estado de espírito dos iniciados, que passa da angústia ao arrebatamento. Essa subversão interior, de ordem afetiva, era obtida por drômena, coisas encenadas e imitadas, por legómena, fórmulas rituais pronunciadas, e por deiknymena, coisas mostradas e exibidas. Pode-se supor que elas se relacionavam com a paixão de Deméter, a descida de Corê ao mundo infernal e o destino dos mortos no Hades. O certo é que, terminada a iniciação, depois da iluminação final, o fiel tinha o sentimento de ter sido transformado por dentro. (...) "Bem-aventurado", afirma o Hino a Deméter, "quem teve plenamente a visão desses mistérios. O não-iniciado, o profano, não conhece semelhante destino depois da morte, na morada das Trevas." (VERNANT, 2009, p.73)
\end{abstract}

Se os Mistérios revelavam aos iniciados os segredos de Hades, os caminhos da morte, como isso acontecia? Sabemos que a lógica e os vestígios arqueológicos, segundo Ruck, negam atividade teatral no Telesterion. Mas objetos eram exibidos (deiknymena), textos eram pronunciados (légomena) e ações eram encenadas (drômena). Um conjunto de atividades que aproxima o rito no Telesterion da arte teatral. E o fato de isso ocorrer desde quase mil anos antes de existir o teatro é aqui observado considerando o acesso dos participantes, sob o efeito do Kykeon. 
Sobre isso, Fauzi deixa uma pista interessante, ainda mais controversa do que o próprio LSD, quando deposita nas intenções, nas circunstâncias e nas condições da experiência lisérgica a "esperança" de otimizar seu potencial, honrando o dom inerente a seu efeito. Para ele, o LSD25 seria "um catalisador químico que nos faculta adentrar a arena (...) que alguns chamam de Astral. O assim denominado Inconsciente Coletivo talvez seja coincidente com o que os antigos chamavam de Plano Astral". (ARAP, 1998, p.261) Casualmente, mas significativamente, o autor evoca um conceito central ligado à Teosofia, sistema de conhecimento difundido pela escritora russa Helena Blavatsky, autora citada duas vezes no Mare Nostrum e sampleada pelo autor na última fala de sua peça Pano de Boca (1974), na boca do personagem Pedro, fala citada no capítulo Cena Química, quando o ator que se cala, inspirado no corifeu Samuca:

ESFINGE - (...) Para chegares ao conhecimento, tens de abandonar a personalidade a não personalidade, o ser ao não ser, e poderás então repousar entre as asas da grande ave. Vê - tornas-te a luz. Tornas-te o som, és o teu mestre e o teu Deus. Tu próprio és o objeto de tua busca: (...) os sete sons em um - a voz... a voz... do silêncio. OM TAT SAT

(Tais palavras são fragmentos do livro A voz do silêncio, de Blavatsky, em tradução de Fernando Pessoa.) FIM (PANO DE BOCA, 2,112)

Quando Fauzi fala em "Plano Astral", traz para dentro desse estudo este sistema de conhecimento não exatamente científico, descrito pelo autor Charles W. Leadbeater, parceiro de Blavatsky na Sociedade Teosófica, como uma filosofia, ao mesmo tempo uma religião e uma ciência. No último caso, porque trataria questões metafísicas "não como matéria de crença teológica, mas de conhecimentos diretos, que se adquirem pelo estudo e pela investigação pessoal", (LEADBEATER, 1997, p.8). Considerando a complexidade da fenomenologia teosófica, povoada de seres invisíveis inusitados e fenômenos psico-físicos extremos, seria a "investigação" de um "pessoal" bastante peculiar, paranormais com habilidades psíquicas realmente fantásticas. Não é o caso de Fauzi, mas este, à sua maneira mais discreta, dialoga com o universo. Sincronicamente, a visão de mundo impressa no livro Mare Nostrum também se declara, a seu modo, baseada em "conhecimentos diretos que se adquirem pelo estudo e pela investigação pessoal". Numa busca do que seria uma Alquimia do Teatro à partir da visão de Fauzi, as palavras do autor nos lançam nesta direção.

No livro O Plano Astral, de C. W. Leadbeater, há uma descrição do que seria a matéria constituinte desta "arena" mencionada no Mare Nostrum: uma materialidade sutil, manifestação de uma "etapa" da "evolução" da "irradiação da força ou espírito divino através 
da matéria", resultando numa espécie de atmosfera ou de oceano mental que envolve o planeta com uma consistência variável. No capítulo III, dedicado à descrição dos "Habitantes" do Plano Astral, no primeiro item da sessão denominada "Não Humanos", esta materialidade sutil é denominada "Essência Elemental”:

\begin{abstract}
"um vasto reservatório de essência elemental extraordinariamente sensível ao mais fugitivo pensamento humano, e respondendo com inconcebível rapidez (...) a qualquer vibração que a aflore, mesmo que essa vibração seja o produto inconsciente de qualquer desejo ou vontade do homem. (...) à menor perturbação, provocada, por exemplo, por qualquer corrente de pensamento que passe, precipita-se imediatamente numa confusão de formas, continuamente móveis, que mudam constantemente; precipitam-se e desaparecem, como as bolhas de vapor à superfície da água em ebulição. (...) um exame mais atento permitirá descobrir nelas uma certa relação com o pensamento que as evocou (...) essa inteligência não provém, evidentemente, da mente do pensador. À essência elemental, em si, não podemos também atribuí-la (...) Contudo, possui uma tão extraordinária capacidade de adaptação que, muitas vezes, parece aproximar-se de qualquer coisa mental (...) Pela extrema precisão com que a essência elemental responde à menor solicitação dos nossos pensamentos e dos nossos desejos, conclui-se que este reino, no seu conjunto, é um produto do pensamento coletivo da humanidade. (LEADBEATER, 1995, p.73/78)
\end{abstract}

A imagem de "um vasto reservatório sensível produto do pensamento coletivo da humanidade" quase descreve o próprio Inconsciente coletivo. Se procede a suspeita de Fauzi, sobre o LSD facultar à consciência a percepção desta presença sutil que nos envolveria com sua atividade normalmente imperceptível; se o Kykeon de Eleusis, tendo o mesmo princípio ativo, teria o mesmo efeito: é provável que a ritualística dos Mistérios operasse em interação consciente com esta presença sutil. Possivelmente incluindo em seus fundamentos o trabalho de ordenação de sua atividade, necessário para que a experiência não fosse a simples percepção de um ambiente tomado pela tal "confusão de formas, como as bolhas de vapor à superfície da água em ebulição" mas sim uma geração de consciência profunda sobre os ciclos da natureza através da vivência do mito de Deméter e Perséfone.

A vivência do mito seria um afluente primordial nessa gênese da linguagem teatral, dentro de uma percepção dessa chamada "essência elemental" e sua atividade, a materialidade do chamado Plano Astral que Fauzi imaginou análogo ou coincidente com o Inconsciente Coletivo, o Mare Nostrum. Com os olhos abertos para este "vasto reservatório", descrito pela Teosofia como o "reino" que é "produto do pensamento coletivo da humanidade", os sacerdotes reconheceriam suas infinitas possibilidades, e trabalhariam para provocar a materialização sutil do conteúdo do mito, a ser criada coletivamente e vivenciada por cada participante. 
Cenas, jograis e símbolos exibidos seriam artifícios para ordenar a atividade sutil da essência elemental, concentrando e direcionando pensamentos e desejos para, nesta, materializar o significado profundo da história da deusa da terra cultivada e seu resgate de sua filha sequestrada pelo senhor dos mortos. Quando cenas eram executadas, palavras pronunciadas e objetos mostrados, a atividade da essência elemental seria formatada pelos pensamentos dos participantes, gerando a materialidade sutil viva dos símbolos presentes. Ao experimentar, visual e sensorialmente, as formas sugeridas pelos deiknymena, légomena e drômena, na percepção dos participantes, ocorreria a presentificação viva do mito, dentro e fora de suas almas.

Para construir essa materialidade sutil tão sofisticada, capaz de revelar os mistérios, talvez fosse preciso mais do que somente os símbolos apresentados no rito. Uma das únicas condições para a participação nos Grandes Mistérios de Eleusis, além do pagamento de um leitão sacrificial e de mãos limpas de crime de morte, era a exigência de que a pessoa falasse a língua grega. Isso garantia um universo cultural comum, delimitava uma região do Mare Nostrum. Não seria só para todos poderem participar das Légomena, garantiria os fundamentos do campo fértil para as evoluções simbólicas operadas no Telestérion. Para que todos trouxessem esse campo ativo e aceso na própria psique, tanto consciente quanto inconscientemente. No mesmo propósito, havia ainda, segundo Brandão, uma longa preparação para iniciação nos Grandes Mistérios, vários meses praticando jejuns e disciplinas. E os Pequenos Mistérios, celebrados no templo de Deméter e Core, onde aspectos do mitologema das deusas "eram mimados, reatualizados e ritualizados" (BRANDÃO, 1987, vol.I, p.298) e onde "cada ação programava em mais detalhes o significado, a substância e as ramificações completas da visão que estava por vir." (WASSON, HOFFMAN, RUCK, 1978, p.19 - ) Em relação ao conceito teosófico evocado por Fauzi, essa preparação faria sentido, porque uma ação criativa automática dos desejos e pensamentos humanos na formatação da chamada "essência elemental", mesmo sendo inconsciente para quase todos, seria tão inexorável quanto possivelmente útil, aplicável de forma consciente e proposital.

O pensamento apodera-se da matéria plástica e molda-a instantaneamente num ser vivo de forma apropriada - ser que uma vez criado, não fica de modo nenhum sob a influência do seu criador, mas vive uma vida sua, cuja duração é proporcional à intensidade do pensamento, ou desejo, que o gerou. De fato, dura enquanto a forçapensamento que o criou lhe mantém a coesão. (...) [pensamentos] imprecisos e fugidios (...) vivem apenas minutos ou horas; mas um pensamento repetido ou um 
desejo convictamente formulado, geram um elemental cuja existência pode durar dias. (LEADBEATER, 1995, p.90)

A descrição propõe uma dinâmica de infinitas possibilidades. No caso, possivelmente aplicada no propósito da produção e execução de uma narrativa mítica em ação real na materialidade sutil e sensorial da "essência elemental" presente no Telesterion. E a forma desenvolvida para esta aplicação seria um roteiro de símbolos, incluindo máscaras, ativados na psique aberta dos participantes em sua experiência lisérgica. Cada símbolo operado no rito ativaria uma rede de compreensões, conexões, sensações e reflexos cuidadosamente preparados para participação de todos numa experiência coletiva de construção mental e imersão sensorial numa narrativa mítica sobre os ciclos da vida e da morte. Seria uma espécie de encantamento matérico do conjunto dos pensamentos dos participantes, criando as imagens e as personagens do mito em algo que se entenderia como uma "alucinação coletiva" mas que pode ser a percepção de uma realidade sutil. Por sua vez, criada pelo próprio pensamento, mas com materialidade, ainda que sutil, e autonomia programada.

Pensando nessa dinâmica como fator coagulante numa possível gênese da arte teatral, chama atenção a ideia de se criar um "ser vivo" a partir de um pensamento ou de um desejo. Seria um elemental - uma diferenciação individualizada da "essência elemental" - com modo de ação definido intencionalmente, ativo numa camada sutil da realidade. Algo instigantemente análogo à ideia do personagem teatral como entidade, ou como um ser imaginário que tem vida própria, sugerida pelos artistas entrevistados nesse estudo em suas falas reunidas abaixo para grifar a conexão das ideias:

\footnotetext{
MARCELO DRUMMOND - De repente, o personagem tá vivo e vai em frente. É uma força inteligente. (...) Se você deixar, foge do controle. (...) Um personagem feito o Hamlet. O Hamlet tem um espírito. Aquilo já foi feito tanto (...) No Candomblé, o Pai de Santo fala "Põe um copo de vinho pra ele porque isso daí já é um espírito, já é uma coisa." Dioniso, Hamlet, todos esses personagens, eles já estão na cabeça das pessoas, elas já projetam aquilo. Tem uma energia ali, projetada. E você tem que pegar aquela energia. Mesmo que você faça diferente (...) tem que se conectar com uma ideia, com uma coisa que é mais do que você. (...) Seria como uma incorporação na Umbanda. De certa forma é o que a gente faz: incorpora o personagem.
}

Marcelo fala da criação de personagens célebres, Hamlet ou Dioniso. Pela repetição do pensamento coletivo, do público e dos artistas, a imagem da personagem viveria a partir das experiências de todos os atores que fazem o mesmo papel. $\mathrm{O}$ alimento dessa energia viva nascida na dramaturgia, seriam as experiências de seus intérpretes e também os diretores, a equipe, o público, os leitores, a crítica. 
CAMILA MOTTA - Ela é muito mais que eu, é a personagem escrita, é o personagem que eu vou fazer, que a Duse fez, que a Sara Bernardt fez, a Isadora Duncan também fez. Então o personagem já tem muito mais possibilidades (...) te dá um outro ponto de vista (...) é um bastão que você pega por um momento da vida, e você vai ver a vida daquele ponto de vista (...) É uma confusão necessária porque você vai enxergar de uma maneira que eu nunca pensaria em enxergar (...) então a minha vida mudou muito à partir disso. E ela muda muito à partir disso."

Mas só se alimenta algo que já tem vida, e a arte do teatro, na função da dramaturgia, em qualquer variação de forma ou processo, é uma semente pode florescer instantaneamente:

PASCHOAL DA CONCEIÇÃO - os caras bons de dramaturgia, eles põem gente falando, mas eles põem correntes energéticas (...) pensamentos, modos de ver a vida, modos de ser (...) forças. E quando você começa a mexer com essas histórias, com essas forças, você começa a trabalhar nela, começa a prestar atenção em como é que ela vem, como é que ela se manifesta (...) quando eu tava criando o Polônio, eu tava muito ligado na coisa da burocracia, de como ela se manifestava no Estado (...) eu acabei virando administrador do teatro, o livro caixa, os contatos com o governo do Estado. E da minha vida mesmo (...) Aquela sabedoria que tava dentro do Polônio, uma espécie de coisa guardada dentro dele, como se fosse um perfume, então aquele perfume vinha pra fora nessas atitudes, eu conseguia por pra fora aquele perfume, aquele negócio (...) o personagem chega pra gente. Ele chega pra você e se apresenta. Você recebe ele (...) esse personagem tem uma vida dentro dele. (...) Ele nasceu pra aprontar. Tem que fazer o que ele tem que fazer. (...) esse negócio, esse comichão, é o que o ator pega pra ele. (...) É uma cosseguinha que o personagem tem, e aí o ator se coça tanto quanto a personagem. É uma cócega."

Talvez a dinâmica se estenda para a peça como um todo, ela também, com sua poesia específica, teria sua energia e sua inteligência autônoma, disponível para manifestação na matéria através de um processo que é, ao mesmo tempo, sua construção pelo coletivo na "batedura" do ensaio.

LUCIANA DOMSCHKE: "É a questão do código genético. Num terço da peça já tem desenvolvido um código genético daquela peça, e aí, não é mágica, põe o nome que quiser, mas é um ciclo. 9 meses gestando, chega uma hora, bum! Estoura a bolsa, nasce! (...) Você faz uma peça, usa 2 meses pra fazer um terço, um quarto, aí tem 10 dias pra fazer o resto, e quando você vê, chegou o dia da estréia e você faz.

As hélices desse DNA seriam as personagens ativadas pelos atores quando encarnam as forças ou vetores dramáticos que devem se cruzar para formar a obra. Inteligências vivas, etéreas, mas específicas, disponíveis ao acesso de seus avatares cênicos. Numa analogia, como uma interface que um ator baixa no sistema psico-físico instalando um outro modo de operação, algo como uma máscara que se integra e determina o todo.

Quando juntamos a ideia das "forças inteligências" das personagens, colocada pelos artistas, com o conceito da "essencia elemental" - como a materialidade sutil de um "Plano Astral" que é sinônimo do "Inconsciente Coletivo" - tomando essa "teoria" como hipótese, 
abrimos espaço para um exercício de pensamento interessante, mesmo se compreendido apenas como metáfora:

O texto teosófico afirma que pensamentos e desejos humanos existem numa materialidade sutil, que compõe um "vasto reservatório" de "essência elemental" que nos envolve - algo associado por Fauzi ao Inconsciente Coletivo - e que constituiria a materialidade sutil do conjunto dos pensamentos e desejos presentes. Sua constituição seria parecida com uma "matéria plástica" sutil, fluida, sensível e formatável. Afirma ainda que o pensamento e o desejo humano seriam capazes de "apodera-se da matéria plástica" da "essencia elemental" - ou da materialidade do Inconsciente - e moldá-la "num ser vivo" "cuja duração é proporcional à intensidade do pensamento, ou desejo, que o gerou”.

Aplicada ao campo teatral, esse conceito definiria aquela "força inteligente da personagem" falada na Oficina Alquímica como exatamente este "ser vivo". Sua força seria proporcional à sua coesão, forjada pela ação dos pensamentos e desejos das personagens vitalizados pelos atores no trabalho da cena. No caso de personagens célebres, Hamlets ou Plufts, essa "consciência" já existiria no Inconsciente Coletivo, e uma parte do trabalho já estaria feita. No caso de personagens novas, releituras, inéditas ou pouco representadas, essa parte da criação dessa "consciência da personagem" se daria no exercício da arte, pela ação anímica dos artistas no ensaio, movendo pensamentos e desejos em carne e osso e formatando magneticamente as nuvens fugidias de "essência elemental". Essa operação contaria com uma característica gravitacional específica que os pensamentos e desejos aplicados exercem sobre a "essência elemental", atraindo para a nuvem elementos afins complementares que transcendem à capacidade de apreensão de um só ator trabalhando num dado tempo espaço. As boas ideias, potentes e bem definidas, tem uma força gravitacional modeladora. Seria o “código genético" cantado pela atriz, o DNA da personagem, que atrai a "essência elemental" correspondente. E daria acesso a consciências muito maiores do que seria possível a uma só consciência construir no tempo do ensaio. Daí a alquimia. A transmutação. Daí a possessão dionisíaca. Consciências específicas, cada uma com seus dons, os dons de Hamlet, Medeia, João Grilo, estariam disponíveis para o artista, podendo ser assimiladas como poder. A serem ordenhadas pelos artistas alquimistas. Porque o ator encarna aquela força, ele tem dentro dele aquele poder. A consciência da personagem agora se soma à sua própria consciência. A consciência dessa simbiose faz com que ela aconteça. Claro, na inconsciência, isso pode ser o 
caos. Porque as melhores personagens seriam sementes capazes de florescer instantaneamente, mesmo fora das condições ideais. Mesmo fora de qualquer padrão formal ou processual, qualquer coisa que age em cena pode vir a ser uma das "ideias, os pensamentos e as forças" de que falam os artistas. A "consciência da personagem", ou da cena ou da obra como um todo, seriam os "elementais individualizados" à partir da a materialidade sutil do Inconsciente Coletivo, a serem ativados pela "batedura" do teatro, do trabalho do dramaturgo até todos os ensaios e montagens.

Alimentado pela repetição dos ensaios e montagens, as grandes personagens cresceriam para sempre na ação dos pensamentos e desejos corporificados nos ensaios, guardadas na materialidade sutil como as máscaras dionisíacas arcaicas, que antes do teatro os gregos viam como forma de "encarnar o deus que [esta] representa. Transformando o exterior, a máscara transfigura o interior, permitindo a quem a usa o desempenho de funções próprias de um ser divino ou demoníaco" (BRANDÃO, 1987, vol.II, p.134).

Por muitos séculos, na Grécia, como em outras sociedades arcaicas, só os sacerdotes usavam máscaras. Mas no caso de Dioniso, segundo o filólogo Albin Lesky, a máscara era praticamente a imagem do deus: em alguns cultos, figurava suspensa num "mastro, era objeto de culto, de tal modo que é possível mesmo falar de um deus-máscara; seus adoradores usavam máscaras, entre as quais a função maior cabia aos sátiros, e máscaras desse tipo eram levadas a seus santuários como oferendas” (LESKY, 1976, p.49). Considerando os mil anos de culto a Dioniso antes do surgimento do Teatro, pelo menos desde o século XV a.C., quando o deus do vinho já era o consorte das deusas em Eleusis, é possível supor que a função da máscara no Telestérion tenha sido precisamente desenvolvida pelos oficiantes dos Mistérios como uma das chaves para a formatação da "essência elemental" na construção da narrativa mítica.

Quando o primeiro ator grego quebrou o protocolo, saiu do coro e dialogou com ele usando uma máscara, foi um escândalo, mas talvez ele nunca fizesse isso sem os mil anos de prática do uso da máscara dionisíaca como guia dos Mistérios, que pavimentava o nível de abstração necessária para se penetrar no domínio da liberdade total do teatro. Por isso mesmo escandalizava, porque o domínio da liberdade total era antes privilégio dos deuses. $\mathrm{O}$ uso da máscara era algo sagrado, possivelmente associado à experiência em Eleusis, e fora daquele contexto, evocava algo extremamente grave e arrebatador, presentificando o êxtase e o 
assombro terrivelmente maravilhosos vividos no Telestérion. Mas já tinha mil anos que Dioniso mostrava suas máscaras em Eleusis, talvez agora o Mare Nostrum geral já estivesse pronto para conhecer a linguagem que vinha sendo incubada. O uso da máscara seria para sempre um culto a Dioniso, de quem a máscara seria uma emanação, e justamente esta ligação direta com o deus teria o poder de ativar a transformação do ator em personagem. A grande Alquimia. Um princípio abstrato que ganharia o mundo, a arte de contar histórias usando personagens.

Se o deus do teatro é o deus-máscara, e a máscara é a versão arcaica da personagem, hoje ela seria essa "consciência da personagem", a consciência dionisíaca, que uma vez alcançada, seria transformadora. Mas esta transformação não seria automática, ao contrário, seria algo ativamente conquistado. A transmutação nasceria de uma integração das inteligências da personagem e do artista enraizada na psique deste último pelo estudo e o trabalho físico mental e emocional com o personagem no exercício da cena. Que daria acesso ao manancial energético, imagético e emocional, ou à "consciência da personagem". Mas além de decifrar a natureza dessa inteligência em sua expressão particular, talvez o maior desafio do ator seria encontrar em si o que ressoa com essa inteligência. A chave para ativar o fluxo da fonte da energia pura. O acesso seria uma integração oportunizada pelo reconhecimento, por parte do intérprete, daquilo que vibra em si mesmo como vibra na personagem. Essa consciência, à partir da vivência - física, mental e emocional - dessa consonância vibratória, daria acesso ao manancial. Seria um reconhecimento da personagem como parte da totalidade que mora no centro da psique do artista - o Inconsciente, individual e coletivo ao mesmo tempo. Qualquer personagem existiria dentro de um ator, fazendo dele a própria personagem. Uma questão de reconhecimento.

Talvez como diria Fauzi: "Sérgio Mamberti é Mic". Ou talvez como dizem os versos alquimistas citados por Jung: “Tudo o que está em cima / Também está embaixo /Percebe-o / E rejubila-te.” (JUNG apud EDINGER, 1995, p.23) 


\section{Capítulo 5}

\section{A Experiência de Fauzi}

O texto a seguir é um argumento para uma dramaturgia de ficção inspirada no livro Mare Nostrum:

\section{A EXPERIÊNCIA DE FAUZI}

\section{INCIDENTE INCITANTE}

Rio de Janeiro, 1971, o paulistano Fauzi Arap tem 33 anos e dá uma aula de teatro numa clínica para pacientes psiquiátricos. Falando aos alunos, diz algo sobre "aguas interiores", quando um deles, meio soturno, responde: - É o Mare Nostrum... Fauzi tem um devaneio instantâneo com flashes de si mesmo no passado e no futuro: 8 anos antes, num consultório médico, tomando injeção no braço; 30 anos depois, escrevendo a máquina: "foi uma revolução total de minha consciência, quinze dias que marcaram toda a minha vida"

Rio de Janeiro, 1963, Fauzi tem 25 anos e está em cena como Frei Timóteo, na peça Mandrágora, de Maquiavel, pelo Teatro Oficina. A platéia assiste, dominada.

Outra noite, num coquetel, ele parece um pouco tímido quando abordado por admiradores que saúdam sua premiação como ator revelação pelo papel. Um veterano faz comentários irônicos sobre sua forma de interpretar. Fauzi pede licença e se afasta para tentar sair à francesa, mas é alcançado por uma amiga, Joana.

Num bar em Ipanema, uísque e cigarros de filtro vermelho pontuam conversas sobre Marx, Godard e Bossa Nova. Joana e Fauzi conversam com amigos quando alguém passa e convida somente ele para uma festa VIP, esnobando os outros. Alguém pergunta se ele fará novelas, outro diz que perdoa se ele for mais um burguês à serviço da manipulação das massas. Disfarçando, ele tenta novamente sair a francesa. Mas Joana o alcança a tempo. Saem juntos.

Caminhando pela rua da praia, falam da vida. Para ele, teatro é um ato político a serviço das transformação social e da conscientização das massas. Mas, se é isso 
mesmo, como pode ser esse culto à vaidade e ao status quo? Não quer entrar em nenhum esquema. No meio teatral ou na política estudantil, percebe contradições graves sob véus de falsas aparências. Sabe que há mais a ser vivido. O sucesso como ator não basta. Ao contrário, instiga ainda mais a decifrar os mistérios.

E Joana também quer mais, fala sobre psicanálise, e conta estar pensando em fazer uma terapia experimental recomendada por um amigo, assunto de um artigo na revista Manchete sobre o novo remédio que levaria ao contato com o chamado "inconsciente". Olhando o mar imenso, do horizonte à areia, Fauzi parece gostar da ideia, e se pergunta como seria sonhar acordado.

De repente, ele vê o mesmo lugar totalmente diferente: dunas ladeiam um pier comprido que entra mar adentro, e uma multidão de hippies se reúne, curtindo a praia e vendo o pôr do Sol. Entre estes, um outro Fauzi, 7 anos mais velho, cabeludo, vem saindo da areia, com amigos, ocupado em cuidar de um deles que parece estar em surto psicótico. Por um instante, os dois Fauzis se olham, intrigados.

\section{ROCK'n ROLL}

No consultório do médico para uma entrevista, junto a Joana, Fauzi ouve a explicação do Dr. Murilo sobre o procedimento quinzenal com o medicamento Delysid LSD25. O médico diz que Fauzi será apresentado à própria essência.

No horário marcado, 7 da manhã no consultório, a substância é ministrada nos dois amigos por injeção muscular. Joana fica na sala do médico e Fauzi numa sala de espera contígua, onde uma secretária trabalha concentrada.

Logo, Fauzi repara no ritmo das teclas da máquina de escrever da secretária, e fica olhando, enquanto ela se incomoda e disfarça. Quanto mais ela tenta esconder o mal estar, mais ele acha graça, progressivamente, até ter um ataque de riso incontrolável. Dr. Murilo aparece, com Joana, e os convida a dar uma volta. Entram num carro e seguem pela rua da praia.

O dia explode de beleza e energia. Chegam a um parque, Fauzi sai pelo gramado, sorrindo, atraído por uma grande árvore. Começa a aumentar de tamanho até ficar da altura da árvore. Olha tudo do alto e vê a si mesmo, no chão, observando. No 
horizonte, surge um templo oriental. E ele se vê no templo: um monge, sorrindo e brilhando imóvel. Uma abelha zumbindo forte o leva a se perceber de volta no parque, com Joana e o médico. Quando vê que a amiga não decolou, a ajuda a entrar em transe.

No caminho de volta, Fauzi entra num devaneio poético sobre um gosto estranho que sente na boca, um certo sabor de resgate ou de redenção.

Sessão encerrada, vai para casa, dorme e tem uma "bad trip", se vê sufocado por um cobertor vermelho e sente a presença da morte.

Dias depois, recebe um telefonema da mãe, e vai a São Paulo encontrá-la. Almoçando num restaurante família, ela conta que sonhou com ele. No dia da sessão lisérgica, sonhou que ele fazia uma operação na cabeça. Depois, faz uma revelação: quando soube estar grávida, tentou abortá-lo. Perplexo, Fauzi saca um caderninho e escreve: "o gosto estranho era leite".

Quando ergue os olhos, observa os presentes: homens de terno e gravata e mulheres com vestidos castos ganham, a seus olhos, contornos dinâmicos e estilizados, e os elementos visuais do ambiente se multiplicam em séries fractais, formando mandalas com mensagens sutilmente libertárias.

Fauzi começa a ensaiar uma nova peça, dirigida por Antunes Filho, Veredas da Salvação, de Jorge Andrade, fazendo uma personagem que cisma ser um novo Cristo. Ao mesmo tempo, começa as sessões lisérgicas quinzenais. Entre estas, faz anotações, toda manhã, e adota um livro de cabeceira, Psicologia e Alquimia, de Jung.

Seu cotidiano parece se tornar algo mágico: Como ator, alcança qualidade e autodomínio incríveis; A timidez some, e ele se revela um ótimo orador e envolve em debates e palestras brilhantes; Ganha um poder de concentração sem limites e age com firmeza confiante no desenrolar dos fatos e numa inspiração que nunca falha.

Numa sessão, se vê pilotando o Sol nascente. E o terapeuta pede cuidado. Mas não adianta. Mesmo saindo da peça de Antunes, Fauzi não se desliga da personagem e insiste em usar a figura de Cristo pelos bares e pontos de ônibus. O sentimento de plenitude encontra decoradas as falas da peça, com sua chave de loucura, e ele assusta as pessoas falando horas sobre experiências sutis. Se salva no carisma e ganha quem se abre, mas se embriaga no próprio discurso e ignora o abismo que vai criando pelo 
vício de falar sem parar sobre coisas impossíveis. Para muitos, o entusiasmo de um jovem intelectual de esquerda falando em Jesus Cristo parece bizarro. Uma noite, depois de uma fala dele numa mesa de bar que espanta os circunstantes, a amiga atriz Maria Alice Vergueiro zomba dele e os dois tem um ataque de riso incontrolável.

13 de Março de 1964, numa sessão com Dr. Murilo, decidem sair do consultório, como da primeira vez. Fauzi quer ir a um comício político com o presidente Jango, na Central do Brasil. O médico resolve arriscar. Estaciona longe para caminharem até o comício. Porém, o estado de Fauzi chama atenção de pessoas passando para o evento, e o médico resolve parar num botequim, onde ficam ouvindo o comício pelo rádio e vendo as pessoas passando enquanto Fauzi vive e compartilha com o médico seu sonho acordado, que se mistura à realidade da rua agitada pelo momento político.

Uma festa em Ipanema, Fauzi conhece a escritora Clarice Lispector, e entre comentários gerais sobre a situação política, dispara elocubrações sobre um "psicodrama cósmico" paradoxal revelado pelos ventos da mudança. A escritora reage com um esboço de sorriso, mas não dá confiança. E se afasta.

Um colega comenta que todos sabem da terapia, mas Fauzi não se importa e brinca, se declara um apóstolo da boa nova lisérgica que democratiza o paraíso.

Mas sua atitude incomoda e chama atenção. Logo todos comentam o ator revelação e seus discursos surreais pelos bares de Ipanema. Vira assunto na cidade.

31 de Março de 64, durante uma sessão, o inconsciente de Fauzi se materializa enquanto ele vê pela janela do consultório os tanques tomando as ruas do Rio.

Nos dias que seguem, todos cautelosos com o novo regime, menos Fauzi em seu entusiasmo inexplicável, atraindo olhares suspeitos dos circunstantes.

Joana procura Fauzi e pede que ele interrompa a terapia. Não gosta de sua mudança radical. Diz que ele é especial, não o LSD, nem Dr. Murilo. Acha irresponsável abrir tanto a psique para outra pessoa. Mas Fauzi diz que o médico é o único que o entende. E mostra fascinação pelo ato de sonhar acordado, interpretar o sonho e agir no sonho integrando os complexos. Um sonho ao alcance da mão. Chama Murilo de mestre. Joana não quer mais nada com isso. Eles rompem. 
Mas ele começa a notar pessoas olhando estranho. Quando pensa estar compartilhando pérolas, percebe olhares condescendentes superiores. Se choca e sofre ao ser mal interpretado, cai num abismo entre sua nova percepção do mundo e a dos outros. Quando finalmente dimensiona o falatório geral a questionar sua sanidade mental e a terapia com LSD, Fauzi desaba. Arrasado, se isola.

Surge novo convite do Oficina para uma substituição na montagem de Pequenos Burgueses no Rio, ele aceita. Porém, nos ensaios, sente a desconfiança dos colegas. Emocionalmente ferido, já não toca no assunto do LSD, e se aprofunda num isolamento angustiado. Ao mesmo tempo, seu trabalho na peça vai ficando sensacional.

A estréia acontece num clima político tenso. Antes do terceiro sinal, o diretor reforça para o elenco a ideia intrínseca à peça de que tudo na vida cotidiana tem sentido, direção e ritmo dentro de uma aparente incoerência, e que nos acontecimentos mais vulgares corre o sangue das grandes conflagrações históricas.

No meio da peça, quando a personagem de Fauzi diz que "a vida avança, velho! E quem não avança ao lado dela fica só", o ator tem novo devaneio instantâneo com flashes extemporâneos se interpondo à imagem dos tanques tomando as ruas do Rio: o palco vira sua sala de aula na clínica psiquiátrica, com o aluno taciturno tendo um ataque de riso; novamente vê a si mesmo 30 anos depois escrevendo à máquina; cenas de repressão policial a protestos nos anos $70 \ldots$

Fauzi mergulha no papel de forma quase suicida. E seu trabalho chama atenção. Dias depois, numa entrevista, Fernanda Montenegro o compara a "Gérard Philipe em $O$ idiota e Galina Ulanova em Romeu e]ulieta". Paulo Francis escreve que ele alcança a chamada "suspensão da descrença". O sucesso é tanto que o ator receber bilhetes e declarações de amor. Mas nada alivia a sensação de inadequação geral.

Numa sessão com Dr. Murilo, Fauzi diz que o sucesso não parece dele. Perdido e inconformado, diz que nem a euforia serena de uma sensação de liberdade definitiva alivia certa culpa por merecer essa libertação particular, o acesso individual a um segredo tão imenso e incomunicável. Não esperava desestruturar tanto suas convicções materialistas, que se confundem o próprio bom senso. Murilo diz ser necessário mergulhar em si para melhor agir no mundo. Diz que essa luta pela própria dignidade leva à evolução, inclusive 
de sua arte. E questiona o que vale mais: sentir-se confortável na própria pele ou realizarse plenamente no exercício de sua arte. Não seria este seu propósito como artista? Fauzi questiona se não seria justamente o outro o propósito de toda vida. Então Murilo faz o inesperado: dá alta ao paciente. Diz que a terapia funcionou, mas que ele ainda levaria uma vida para digerir. Fauzi não acredita. Não concebe perder o único cúmplice. O psiquiatra fala do comportamento indiscreto dele, conta que o Delysid LSD25 é um remédio experimental controverso, e sendo ele um ator conhecido, no governo militar, prefere evitar suspeitas.

Fauzi volta a São Paulo desnorteado. Então recebe um telefonema de Maria Alice: burocrática, ela conta que tomou o "ácido" mas não está sentindo nada, está com seu médico numa choperia em Pinheiros, bebendo. Aturdido, ele vai até os dois e constata que ela não sente nada mesmo, mas o médico, sim, está bem louco. Acaba cuidando deles, estabiliza a viagem do médico e ajuda Maria Alice a ter uma boa experiência.

Depois dessa, se entoca, lendo vários livros ao mesmo tempo. Dias depois, é chamado a atuar numa peça com grandes nomes do teatro tradicional.

Maria Alice aparece trazendo LSD em 2 pílulas roubadas de seu médico. Mas ele não tem condições. E desabafa sobre a dor do fim de sua terapia. Punido pelo entusiasmo, perdeu a cumplicidade do mestre e queimou o filme no meio social. Não sem orgulho, reconhece não ser mais uma unanimidade. E sugere que ela dê as pílulas o para algum amigo. Ela o parabeniza pelo novo papel, mas ele se mostra apreensivo.

Nos ensaios, Fauzi não se adapta ao novo esquema de trabalho. Diante das vozes bem colocadas dos outros atores, treme de insegurança, chega a suar frio. E tem mais um devaneio instantâneo: entre mais imagens extemporâneas de si mesmo, vê um deus criança sendo desmembrado e devorado por figuras nuas pintadas de branco.

Depois disso, abandona a produção e vai trabalhar em outra peça, $O$ Inoportuno, de Harold Pinter, com direção de Antônio Abujamra e Emilio di Biasi e Sérgio Mamberti no elenco. Já perto da estréia, Sérgio está insatisfeitos e angustiado com seu desempenho. Então Fauzi diz saber porque não está funcionando. Diz que Sérgio não precisa fazer nenhum esforço para ser o personagem porque, por definiç̧ão, ele é o personagem. É quem faz o personagem, portanto é o personagem. Sérgio resolve experimentar e o resultado é excelente. 
Por sua vez, Fauzi está em crise com um bigode postiço que é obrigado a usar. Sem tempo de se acostumar, na noite de estreia, o bigode descola e fica torto durante a peça, levando Fauzi a uma crise de nervos. Na hora dos aplausos, reage com repulsa aos abraços de Sérgio, e declara encerrada sua carreira de ator.

No camarim, depois do stress, Fauzi tem um momento de catatonia, quando recebe a visita de uma admiradora, a escritora Clarice Lispector, que aparece com um amigo, diz acompanhar seu trabalho e traz para ele um exemplar autografado de seu último livro, “A Paixão Segundo GH”. Meio amargo e sem jeito, ele não dá muita bola, e ela vai embora.

Horas depois, o zelador do teatro encontra Fauzi lendo em êxtase. Ao ver o zelador, lê para ele um trecho: "estou procurando, procurando. Estou tentando entender. Tentando dar a alguém o que vivi e não sei a quem, mas não quero ficar com o que vivi. Não sei o que fazer do que vivi, tenho medo dessa desorganização profunda."

De repente, tem mais um devaneio instantâneo: vê a imagem de uma deusa resgatando dos restos mortais do deus criança desmembrado seu coração, que guarda dentro do próprio ventre.

\section{FREE JAZZ}

Em meio a reações indignadas com sua atitude de sair da peça e decretar o fim da carreira de ator, fortalecendo ainda mais o estigma que vinha formando, Fauzi procura a escritora com o desejo de adaptar seus textos para o teatro.

Clarisse pergunta desde quando ele é diretor. Fauzi desconversa e fala do desejo de adaptar seus textos por entendê-los fundamentais num tempo sombrio e luminoso. Seu livro é o relato de uma viagem essencial, um registro que vai além da cultura e da estética, uma revelação, um rito iniciático, algo que ele precisa compreender e o único jeito de fazer isso é transformando em cena. Ela resolve dar uma chance.

Começam os ensaios. Clarisse vai assistir e não reclama de nada. Fauzi ganha confiança. Conversam, então ela conta também se incomodou com a insistência dele 
em anunciar enfaticamente suas epifanias herméticas, quando nem ele, nem ninguém normalmente domina o impacto desse tipo de percepção. Para comunicar o desconhecido, recomenda sobriedade e delicadeza extrema. Fauzi diz que todo processo com o texto dela devolveu a ele uma identidade perdida, reintegrou as experiências vividas e acabou com sua decisão de calar. Aprendeu com ela todo cuidado com a linguagem necessário para não se trair nas palavras e ultrapassar a arrebentação das subjetividades. A dificuldade de expressar o inexprimível, o conflito entre dizer ou não: para ele, é a questão fundamental do momento.

Dezembro do mesmo 1965, Fauzi estréia como diretor da peça Perto do Coração Selvagem. Estão presentes artistas, intelectuais, críticos. Paulo Francis, Oto Lara Resende, Millôr Fernandes, Tonia Carreiro... A peça é sucesso bombástico de crítica, a temporada vai bem. Ele fica em evidência, cheio de amigos, recebe muitos convites. Mas quase nunca atende. Sempre sozinho, lê compulsivamente.

\section{FLORES}

1967, em São Paulo, Fauzi conhece José Vicente, dramaturgo de 22 anos que lhe mostra a peça "Santidade", sobre um ex seminarista que explora um amante. Tônia Carrero produz a peça, mas dias antes da estréia, a montagem é censurada. E citada na TV pelo presidente General Costa e Silva como exemplo de espetáculo que "jamais seria encenado no País."

Mas Fauzi não se abate, no mesmo ano dirige outras duas peças, não menos subversivas, cruéis e violentas: Dois Perdidos Numa Noite Suja, com Nelson Xavier ${ }^{43}$ e ele mesmo, numa derradeira atuação; e Navalha na Carne, as duas de Plínio Marcos, a segunda estreia no ano seguinte, no Rio de Janeiro, com Tônia Carrero em atuação espetacular. A crítica registra que a peça fascina até o público conservador indisposto à subversões.

Um dia, no velho bar em Ipanema, um amigo oferece um ácido, e Fauzi, surpreso, pergunta se o sujeito é psiquiatra. O outro explica que o Delysid foi proibido

\footnotetext{
43 Nelson Agostini Xavier (1941 / 2017) Ator premiado, autor e diretor de teatro, mineiro de Uberlândia, cinco décadas de carreira em teatro, TV e cinema. Teve o primeiro casamento com a atriz Joana Fomm.
} 
e o que tem são comprimidos que arranjou com outro amigo. Fauzi acha estranho, mas o amigo ouviu falar que ele gosta, dá 3 comprimidos de presente.

Em sua casa, Fauzi faz um café e senta diante de sua mesa de estudos, onde abre um livro entre os muitos volumes grifados e cadernos com anotações espalhados pela mesa. Então abre uma gaveta e vê a caixinha com os 3 comprimidos.

Faz uma sessão de LSD sozinho no apartamento, cercado de livros e anotações. Tem visões, interage com elas e toma notas. Quando passa o efeito, estuda o registro dos símbolos liberados na viagem, usa seus livros, faz novas anotações.

De volta à São Paulo, recebe o dramaturgo José Vicente para conversar sobre sua nova peça $O$ Assalto. Mas o amigo abre distraidamente uma caixinha que vê sobre a mesa, onde estão os dois comprimidos restantes. Ao saber o que são, vence uma resistência considerável de Fauzi e o convence a tomarem juntos. Saem pelas ruas sonhando o teatro como semente de um ato mágico poderoso com artistas feito magos comunicadores do invisível, médiuns criando divindades na platéia.

1969, a peça $O$ Assalto estreia bem. Fauzi se consagra como diretor excepcional. No hall do teatro, é apresentado por Tônia Carrero à psiquiatra Nise da Silveira, que convida o elenco para um jantar em sua casa.

Dra. Nise os recebe em seu apartamento, povoado por dezenas de gatos. Um deles em especial vem roçar a perna de Fauzi, e a médica explica que ela é a lider. Seu nome é Madre Superiora. Enquanto os felinos passeiam entre os convidados, o ator, entusiasmado, fala da vida como jogo de forças poéticas acessíveis por codificação estética, numa linguagem dos símbolos que faria do tempo uma criação coletiva.

Fauzi dirige alguns textos de novos dramaturgos em montagens libertadoras. Nos ensaios, tem flash backs lisérgicos. Enquanto isso, a situação política se agrava com o AI5, e o movimento hippie floresce.

\section{DUNAS}

1970, Fauzi está nas Dunas da Gal, nome do ponto de encontro dos hippies da temporada, um acidente geográfico causado pela construção do emissário submarino, que inclui um comprido pier avançando mar adentro. 
Num momento em que observa algumas pessoas tomando ácido e outras sob o efeito, agindo de forma mais ou menos orgiástica, encontra a velha amiga Joana. Sóbria, ela pergunta o que ele acha daquilo. Afinal, é um veterano. Fauzi acha um desperdício e um perigo. Não concorda porque a transformação que a experiência lisérgica impôs à sua vida foi muito arriscada. O choque do paradoxo de vivenciar percepções bombásticas incompartilháveis não passou, e sente que não vai passar.

Joana lembra um grupo de teatro norte-americano que dizem usar LSD no processo teatral, o Living Theatre. Fauzi conta que vai a um encontro com o grupo junto ao Teatro Oficina, de São Paulo. Excitada, ela também quer ir.

Semanas depois, Fauzi e Joana estão numa reunião com o Living Theater na sede do Oficina. Cerca de quarenta pessoas sentadas em roda com os líderes do grupo estrangeiro, Julian Beck e Judith Malina, que falam para os jovens atores, atrizes e artistas fascinados por sua aura e estética de vanguarda internacional. Fauzi sente o movimento entre as lideranças. Ambos contestam a opressão do "sistema", mas cada um de um jeito. Então decidem testar a parceria experimentando um jogo teatral.

O Living Theater distribui ácido para os participantes.

Fauzi olha ao redor. A maioria dos presentes tem dez anos a menos que ele. E a excitação geral contrasta com seu olhar para o comprimido.

Rola a viagem coletiva: atores improvisam um jogo teatral ritualizado, alguns dançam, outros transam ou fazem coisas sem sentido. Todos sonham acordados, seus sonhos se materializam em símbolos arquetípicos ligados ao encontro entre os grupos, as visões de mundo, as nacionalidades e heranças culturais.

Fauzi vê imagens de disputa e abuso de poder, quando se aproxima um ator do Oficina, chamado Samuca, que parece agoniado e fora de si, mas contracenando com ele se harmoniza, e isso o instiga. Porém, são interrompidos por Joana, que aborda Fauzi romanticamente, e ele se deixa envolver num beijo.

Depois do furacão, Zé Celso anuncia que o Oficina e o Living Theater cancelaram a criação conjunta, mas os convidados ainda farão um projeto no Brasil, e querem a participação de atores brasileiros. A notícia anima a todos querendo entrar para o Living Theater. A produtora Ruth Escobar sugere Fauzi para a função. E os estrangeiros querem ouvi-lo. 
Ele começa a fala, reticente, enquanto o ator Samuca ainda chama atenção, agoniado e fora de si. Fauzi fala de abuso de poder, fala da língua do colonizador criando o glamour e a mistificação que subjuga, e fala na confusão de misticismo e esoterismo causando deslumbramento e deriva geral. Questiona se o uso leviano do ácido não é um abuso perigoso contra a alma. Mas compartilha da intenção libertária do grupo e da fé na magia do teatro pela codificação estética da realidade, mesmo com o risco da loucura. Conclui falando em delicadeza e solidão, agradece por contracenar com o inconsciente de todos, mas se diz ocupado e recusa o convite.

1971, Fauzi está no Rio dirigindo Rosa dos Ventos, um show de Maria Bethânia. Uma tarde, num botequim de calçada com a cantora e o amigo Flávio Império, cenógrafo do show, falam animados sobre o desejo de equilibrar as ondas psíquicas da multidão em dias violentos de Ditadura Militar. Com o símbolo da Rosa dos Ventos, querem plantar harmonia no Inconsciente Coletivo, mapeando as funções humanas: o sentimento equilibrando o pensamento, e a intuição complementando a sensação e vice versa. Os amigos tem ataques de riso lembrando não ter conseguido evitar uma quinta parte intrometida no show. Fauzi diz que o cinco é o centro da mandala, a chave que faz a obra do artista ser sua própria vida.

Então aparece Joana, que estava passando e fica tão animada ao ver Fauzi que os amigos acham melhor deixá-los sós. Ela o abraça e fala do momento romântico que viveram. Mas ele diz que foi um engano. Magoada, ela levanta para sair, mas ele a segura, diz gostar de sua amizade, e a convida para a estreia do show, em algumas semanas. Mas antes que ela responda, sai apressado para um compromisso.

Fauzi está na casa de sua conhecida Doutora Nise da Silveira, onde propõe dar aulas de teatro aos pacientes de sua clínica, a Casa das Palmeiras. Para ela, é uma honra tê-lo em sua equipe.

Fauzi começa a cuidar de um grupo de alunos pacientes psiquiátricos, entre eles, o homem taciturno que fala sobre o "Mare Nostrum". Na convivência com seus alunos e com suas fronteiras diluídas entre consciente e inconsciente, encontra respostas para perguntas que não sabia formular.

A estreia de Rosa dos Ventos é um sucesso espetacular. Num grande teatro superlotado de cabeludos do chão ao teto, Fauzi e Joana assistem Maria Betânia 
falando um poema dele. Enquanto alguns ainda brigam para entrar, o público desbunda de felicidade, puxam a roupa dela, homens, mulheres, todo mundo em êxtase.

No hall do Teatro da Praia, depois do show, há uma aglomeração festiva em torno de Betânia, Fauzi e Flávio. Clarice está presente e sobre uma escadaria, maravilhosa. Todo mundo olha e ela declara: "Esse show não termina nunca!".

No meio da festa aparece Zé Celso e aborda Fauzi sobre sua experiência como terapeuta amador, e pede que ele trate um de seus atores, justamente Samuca, grande corifeu nas peças Roda Viva e de Galileu Galilei, que surtou o e há semanas não diz palavra. Fauzi hesita: não é terapeuta. Zé Celso palpita que a questão do Samuca tem a ver com teatro, não com doença mental. Mas a conversa é interrompida por Zé Vicente, que abraça o amigo e diz: "Você conseguiu!

Então Fauzi tem outro devaneio instantâneo. Num flash, enxerga o deus grego Zeus fazendo amor com a mortal Sêmele, que se esvai num gozo infinito.

Dias depois, Fauzi começa o trabalho com Samuca. Reúne alguns parceiros em casa e fazem jogos teatrais com símbolos. As primeiras sessões são sucesso, outros atores aparecem. Nas sessões seguintes, surge mais ouvintes.

Fauzi está tranquilo. Vive o sucesso. A ditadura oprime, mas ele já conhece a morte, usou a condição de artista para ter esse conhecimento em vida; e flutua na força, como Dioniso no útero de Sêmele. Dedica-se a contracenar com as profundezas da alma humana, a própria e a dos outros, tanto no grupo com Samuca quanto na clínica da Doutora Nise.

Volta a usar o LSD como forma de autoconhecimento, desenvolvendo um método de estudos solitários diante de sua máquina de escrever.

E segue dando aulas na clínica. Um dia, um helicóptero sobrevoa o prédio enquanto os alunos fazem o exercício de repetir a letra "M" vibrando as caixas cranianas. $\mathrm{O}$ homem taciturno que falou então tem um ataque de riso e fala pela segunda vez: - É uma piada que Ogum me contou lá fora... De um homem que pegou um helicóptero, e foi embora, partiu... Encontrou uma pedra preciosa e nunca mais voltou."

Já no grupo de Samuca as coisas não vão bem. Ele melhora um pouco, mas depois tem uma recaída e fica ruim. E as reuniões se tornam acontecimentos 
disputados por jovens ávidos pela "sabedoria" de Fauzi. Ele percebe que muitos estão lá com segundas intenções, na esperança de que ele, um diretor famoso, realize algum trabalho com elas. Na verdade, estão todos muito perdidos. Para dar exemplo, Fauzi decide parar totalmente com as drogas. E abandona as sessões lisérgicas solitárias. Mas não adianta nada, o grupo está cada vez mais perdido. Então ele perde a paciência. Num derradeiro encontro, enfurecido, rejeita o papel de guru e bota a horda pra correr.

Deprimido com o acontecimento, Fauzi foca nas aulas na clínica, com atenção especial a uma paciente, Lila que o intriga. Ela não parece, a princípio, ter qualquer distúrbio mental. Porém, só fala por frases feitas, ou pergunta se fadas não existem mesmo, sempre com um risinho idiota na boca. Um dia, no segundo ano de aulas, depois de um processo terapêutico que Fauzi conduz com capricho totalmente experimental, ela pede uma conversa a sós e diz: “É como se tivessem derrubado todos os meus escudos, é como se tivessem rompido minha couraça... e todas as minhas defesas, e é como se eu fosse um barco e estivesse levantando âncora.”

Animado, ele sente que ela está curada. Mas ele precisa fazer uma viagem com o Rosa do Ventos à Bahia, e quando volta, é informado que aquela paciente tinha tentado suicídio. E a notícia traz implícita uma acusação velada.

Ele tenta marcar uma reunião com Dra. Nise na clínica, junto a outros médicos, mas ela marca em seu apartamento. E Fauzi leva um dossiê sobre o trabalho, resultado de uma dedicação metódica, desenvolvida na faculdade de engenharia.

Recebido pelas dúzias de gatos, quando senta-se à frente da médica, em seu escritório, Fauzi coloca sua pasta sobre a mesa. E a gata Madre Superiora, aquela que uma vez roçou na sua perna, pula sobre a pasta e se acomoda.

Depois do cafezinho, quando Fauzi vai entrar no assunto da reunião, Dra. Nise o interrompe, e avisa: Se a Madre Superiora não sair de cima da pasta, não quer saber o que Fauzi tem a dizer. E não deixa que ele entre no assunto, aguardando que a gata se levante. Meia hora depois, a gata continua lá, e nada. Então Fauzi fica nervoso, anuncia seu afastamento e sai andando.

No elevador, tem um último devaneio instantâneo, vislumbra Semele sendo fulminada por raios divinos de Zeus mostrando toda sua divindade. 


\section{A JAZIDA}

Fauzi conversa com os amigos, inconformado. Tenta decifrar a mensagem da gata Madre Superiora. Seria o instinto sensual negando a busca do conhecimento objetivo sobre o inconsciente e os limites entre loucura e plenitude? Afinal, porque ele mesmo produziu aquele símbolo? A desesperança faz querer introjetar todos os valores caretas do mundo compartimentado que nunca lhe serviram, procurando uma forma de caber no sistema. Pensa em mudar de profissão e oficializar a relação com a Psicologia, e chega a procurar um cursinho pré vestibular. Mas desiste. Talvez porque precisasse do impasse para chegar à percepção definitiva de que só a arte, a linguagem subjetiva e o universo simbólico aplicado tem a capacidade de investigar o desconhecido, desbravar poeticamente novas realidades, e comunicar este tipo de movimento em direção ao futuro.

Então percebe que precisava de mais essa morte pra chegar à compreensão do papel da arte como único meio de resolver sua ânsia por retribuir ao mundo uma sabedoria que a vida tinha posto na mão dele. Num dado momento ele se toca, e, como forma de sobrevivência psicológica, decide escrever. Compra uma máquina de escrever nova e se isola por meses em seu apartamento, escrevendo compulsivamente.

Chega a estreia de seu primeiro texto teatral, Pano de Boca. No palco, a personagem Magra diz a um interlocutor invisível: "Eu acho estranho as pessoas não temerem a palavra. Ela é uma coisa mágica, eu acho até que é a coisa mágica.” Na voz das personagens, o sumo poético de sua história e de sua sensibilidade no tempo.

\section{O ELIXIR}

Depois da estréia, no saguão do teatro, alguém vem até ele e diz: Obrigado por escrever isso por nós. 


\section{CONCLUSÃO}

\section{ALQUIMIA DIONISÍACA}

Quando se detecta, na trajetória de artista de Fauzi Arap, um processo alquímico como o observado nos primeiros dois capítulos desse estudo, não se supõe que ele tivesse consciência objetiva desse processo como um todo. Inclusive porque seu caminho foi feito de ações criativas e acontecimentos improvisados no melhor dos sentidos. Ele era bom precisamente em criar novos caminhos. Porém, a alquimia, do ponto de vista psicológico, é necessariamente um processo consciente. Por definição, a alquimia é uma intervenção intencional no curso natural das coisas, para uma transformação da matéria, senão instantânea, bem mais rápida do que o normal. Não existe processo alquímico ou alquimia exatamente por acaso. Além de intencional, pela natureza complexa dos processos, não seria possível vivê-los sem um mínimo de consciência, e por sua natureza às vezes dolorosas, não seria provável vivê-los sem uma vontade determinada. Mesmo assim, quando se aplica sobre a trajetória de Fauzi o modelo mítico de uma "alquimia dionisíaca", o encaixe indica que a alquimia foi feita. E se há alquimia, há consciência. Então podemos supor que a consciência seria diferente daquela estratégica, macroscópica, impossível de se aplicar de antemão sobre uma trajetória de vida rica em escolhas feitas no calor do momento. Não seria possível a consciência do processo inteiro, mas uma consciência que se tornaria inteira pelo exercício diário da atenção cuidadosa no aqui e agora, na soma da consciência de cada instante. Ligada na busca ativa do conhecimento das dinâmicas profundas da vida e do alinhamento vivo com este conhecimento na prática da arte e da presença no cotidiano.

\footnotetext{
$(,$,$) não me cansava de estudar e ler muito, sempre Jung. Todos os dias pela manhã$ anotava meus sonhos, tentando descobrir neles um suporte para a transformação alquímica que buscava em mim mesmo, ao ter me despojado de tudo e apostado todas as fichas numa radical transformação. (ARAP, 1998, p.125)
}

O hábito da consciência do presente focado na alquimia habilitaria a consciência para a grande alquimia fora do tempo. As escolhas regidas pela consciência do momento se somariam numa grande consciência que possibilita a alquimia de longo alcance. Essa disciplina seria um diferencial básico num artista alquimista. 
Mas o desenho da trajetória alquímica de Fauzi vivida na chave do arquétipo dionisíaco é uma das máscaras da "alquimia do teatro" sugerida nas linhas e entrelinhas de seu Mare Nostrum. Outra síntese possível se delineia nesta investigação.

Fauzi afirma que todas as suas experiências poderiam ter sido vividas "prescindindo do ácido" e essa afirmação, hoje, no contexto da prática teatral, faria ainda mais sentido, inclusive, graças au experiências como a dele. $\mathrm{O}$ acúmulo das experiências guardadas no Inconsciente Coletivo facilitaria seu acesso na batedura da cena, exercícios teatrais e outras técnicas dariam conta de encaminhar o êxtase dionisíaco necessário, no balanço com a energia apolínea que juntou forças para formatar a arte. Sem a necessidade das substâncias. Em última instância, as viagens lisérgicas de todos os artistas e psiconautas que já existiram seriam também nuvens de consciência que se pode acessar e conhecer seu poder através da prática teatral.

Uma forma de alquimia do teatro que se delineia ao longo desta investigação talvez possa ser descrita como: o exercício da arte teatral dentro da consciência de sua capacidade inerente de formatar a materialidade dos pensamentos e desejos coletivos, particularmente do elenco, e da equipe, e depois do público, criando vórtices de energia mental e emocional que formam mananciais de informação e vibração específica de personagens, cenas ou ideias. Formas vivas de pensamentos que podem ser acessadas fisicamente, mental e emocionalmente pelos artistas, e operados em função dos objetivos da peça. Sejam objetivos intrínsecos da obra, ou objetivos da peça enquanto acontecimento político, já que essa operação implicaria num aumento de potência de seu conteúdo.

O primeiro passo da operação seria a consciência na criação desses vórtices, ou da “consciência da personagem". Seria também a ativação dessas inteligências quando pré existentes - grandes personagens, ou personagens representativos de grandes forças ativas no Inconsciente. E o segundo passo, a transmutação dionisíaca, se daria à partir da capacidade de um ator ou atriz de se conectar ou se fundir a esses vórtices, "a consciência da personagem", integrando sua inteligência à atuação. E também a vida, podendo ser transformada em poder, no trato consciente.

Essa conexão se daria pelo reconhecimento, por parte do ator ou atriz, da energia que anima a "consciência da personagem" vibrando na própria alma. Sentir a vibração da personagem e encontrar em si o que ressoa à mesma vibração, possibilitando a ligação e o 
acesso aos arquivos etéreos da "consciência da personagem". O êxtase dionisíaco transformador seria esse encontro de consciências: a nuvem da personagem entrando na psique do ator.

\section{DEUS DOS ENEBRIANTES}

Seguindo as pistas deixadas por Fauzi em sua associação entre a arte teatral e a tradição alquímica, chegamos a uma noção da "alquimia do teatro" que resgata a natureza alquímica do próprio mito fundador dessa arte, Dioniso, o chamado deus da transformação. E também chamado deus dos inebriantes, coerentemente com o incidente incitante da narrativa de Fauzi, a experiência lisérgica, que observamos neste estudo para chegarmos a conclusão de que, apesar de ser estrutural nesse caso, e apesar da ancestralidade em Eleusis, para o exercício da "grande arte", não seria algo estritamente essencial. Ele próprio afirma: “é importante registrar que quase todas as experiências já relatadas aqui poderiam ter sido vividas prescindindo do ácido.” (ARAP, 1998, p.86) A afirmação surge a respeito de uma espécie de cura psíquica ou espiritual que ele teria operado numa pessoa durante uma viagem lisérgica, mas pode-se ler que ele falava de todas ou quase "todas as experiências já relatadas" no depoimento. Com relação à prática teatral, a simples consciência desta qualidade alquímica do teatro e a ação ou a intenção de agir nesta dimensão da realidade, unida à qualquer tipo de prática estritamente teatral, seria a chave para esse tipo de operação. Essa consciência e essa ação, hoje, se apoia na consciência e na ação de todos que vieram antes. Numa visão otimista, toda contracultura histórica brasileira funcionaria como uma Iniciação coletiva para a humanidade. Fauzi escreve sobre seu processo de "alargamento da consciência" experimentado na vanguarda do movimento:

Talvez o que eu tenha vivido ao lado de Murilo naqueles dias fosse mais um processo desse tipo (...) no processo de iniciação, os mestres adiantam um empréstimo de luz e percepção, para que seja possível o salto de qualidade na consciência do discípulo. Ele consegue uma Visão, ou antevisão, de uma plenitude possível, mas que ainda nao é exatamente sua. A conquista definitiva demanda muitos anos, ou vidas, até que possa efetivamente acontecer. (ARAP, 1998, p.54)

Nós, humanos, seríamos esse discípulo, já experimentado na percepção expandida, vivendo o processo descrito por Fauzi na sequência, em que "se alternam momentos de certeza e crises, que obrigam que a vontade seja exercida e temperada pelos desafios, até que a 
fortaleza do indivíduo desabroche plena e a transformação seja irreversível, pelo pleno conhecimento alcançado.” (ARAP, 1998, p.54).

Mas é importante dizer que esta conclusão não parte de qualquer objeção quanto a experiência lisérgica vivida adequadamente. Na verdade, o conjunto das informações reunidas neste estudo sugere um questionamento que não pode deixar de ser feito.

Tudo indica que o mundo está, hoje, numa crise que se aprofunda na falta de consciência geral. Pode-se dizer que os grandes males que hoje agem na sociedade, medo, mentira, ganância, violência, resultam de uma certa deficiência geral na percepção do infinito e da interdependência inexorável entre todos os seres, humanos ou não. É a falta de consciência que alimenta todos os males do mundo, e que se mostra progressivamente devastadora. Enquanto isso, o ácido lisérgico, assim como outras substâncias de efeitos análogos, as chamadas substâncias enteógenas, apesar dos perigos do uso inadequado, agem justamente na abertura desse tipo de consciência. Que seria a percepção do "teatro subterrâneo de operações" enxergado por Fauzi. Algo, na verdade, absolutamente necessário e urgente para toda a humanidade. A impressão que dá é que o mundo precisa de uma transformação rápida, uma verdadeira alquimia. Nesse sentido, a experiência de Fauzi talvez revele uma sabedoria útil na soma para um desenlace positivo da crise.

Talvez o que seja apaixonante no ácido seja a possibilidade de derrubar as defesas psicológicas que poderiam impedir o sucesso do objetivo determinado, e o fato de conseguir ampliar a percepção dos envolvidos quase que instantaneamente, transpondo a barreira da linguagem (ARAP, 1998, p.).

Pensar num processo coletivo de expansão da consciência em grande escala com base em práticas que incluem o uso desse tipo de substância seria realmente algo fora de propósito. Uma proposta absurdamente dionisíaca. Mas, considerando a urgência que se observa de uma rápida expansão da consciência da espécie humana como um todo, talvez possamos aprender alguma coisa com o exemplo histórico de Eleusis - na hipótese da natureza enteógena do Kykeon.

A região de Micenas, segundo o historiador Carl Ruck, tem a etimologia de seu nome Mykenai - derivada "corretamente de Mykene, a noiva dos mykes ou cogumelo" (WASSON, HOFFMAN, RUCK, 1978, p.05 - tradução nossa). Ou seja, se o Claviceps Purpurea foi o cogumelo que deu nome ao grande centro de poder cultural e militar do chamado período Micênico, nos primórdios arcaicos da civilização grega, desde 1600 a.C., mais de mil anos 
antes do período Clássico, a importância cultural e a longevidade dos Mistérios provaria sua força como fator determinante não só na gênese do Teatro, mas no desenvolvimento peculiar da civilização grega, e portanto na raiz mais profunda própria civilização ocidental. A julgar pela influência determinante desta cultura em especial no desenvolvimento de toda a cultura atual, principalmente a ocidental, mas não apenas, pode-se dizer que toda a cultura grega significou um "salto de consciência" da humanidade. Talvez, não por acaso, hoje dominada pela linguagem audio-visual que nasceu no teatro e foi do cinema à propaganda e aos games etc., todas linguagens filhas da dramaturgia, a arte de contar histórias usando personagens.

Esta forma de ver o mundo, que inclui a liberdade total da ficção e a possibilidade do transe, talvez se configure um paradigma, o chamado "espírito dionisíaco". Que teria ficado incubado em Eleusis durante mil anos antes do nascimento dessa forma de arte, mãe de tantas outras. Pelos séculos, os mascarados teriam catalizado os pensamentos e desejos do coletivo humano presente, concentrando a "energia" pela operação dos símbolos vivos, pilotando a presentificação do mito das deusas na consciência dos participantes. Nos dois mil anos de atividade dos Mistérios, desde quase um milênio antes do surgimento do teatro, sacerdotes e sacerdotizas de Eleusis seriam a raiz dionisíaca da mata intrépida que segue florescendo na alma de todos os oficiantes da cena. Durante todo esse tempo os Mistérios foram praticados e frequentados regularmente por cidadãos de toda a Grécia, e a influência desta prática ficou registrada em textos de personagens como Aristóteles, Píndaro e Plutarco. Porém, somente mil anos depois de iniciada sua prática, os Mistérios de Eleusis foram finalmente aceitos na Pólis como parte da religião oficial:

Dioniso e Deméter, por motivos de ordem política e social (...) ficaram por longos séculos confinados no campo, mas, a partir de Pisístrato e logo depois, com a democracia, os Mistérios de Elêusis podem ser considerados como uma complementação da religião olímpica e dos cultos públicos, sem nenhuma oposição às instituições religiosas da pólis. (BRANDÃO, 1987, p.296)

O mitólogo fala sobre a ação do governante Pisístrato como responsável pela aceitação dos Mistérios de Eleusis como parte da religião oficial, significando a integração do paradigma dionisíaco ao sistema de valores que regiam a Pólis.

tratava-se de um culto desestabilizador e suspeito, que exaltava a figura da mulher em contraposição ao domínio do homem. Os Mistérios abriam-se democraticamente a todos, até mesmo aos escravos (...) O Estado terminou por tolerar as práticas dos Mistérios, pois Deméter e Perséfone, afinal, eram responsáveis pelas sementes, e destas dependiam os frutos e o bem-estar da coletividade. (MURARO apud BRANDÃO, vol.II, 1987, p.11) 
Isso teria acontecido no século VI a.C. logo antes do surgimento da democracia. Na verdade, logo antes do impressionante florescimento de toda a cultura grega observado no Período Clássico. Tempo em que se produziram as germinais contribuições da antiga civilização grega para a formação da atual cultura global. Dada esta "coincidência significativa", é necessário associar o papel dos Mistérios de Eleusis - e do Kykeon, com sua capacidade de promover a expansão da consciência - ao grande florescimento cultural que se seguiu imediatamente, o grande salto de consciência da humanidade que foi a Cultura Clássica.

Ligando os pontos, a ideia de um salto de consciência é a mesma ideia do "êxtase dionisíaco", que poderia talvez ser descrito como a transformação imediata causada pelo contato direto com a imensidão do Inconsciente. O depoimento de Fauzi dá testemunho do grande risco que se corre quando se busca essa alquimia, ou esse "salto de consciência", seja da forma que for. Mas também revela como ele fez a alquimia funcionar, encarando os riscos, encarando a morte, inclusive, mas chegando, talvez, ao ouro alquímico. No caso dele, talvez a simples paz de espírito na capacidade plena de sua arte. Sem contar o fio de Ariadne que conduz esta investigação. E no relato dessa vitória do artista se podem ler instruções valiosas no sentido de renovar esse êxtase dionisíaco, talvez até de re-editar o "salto de consciência" eleusino de alguma outra forma, ainda a ser desenvolvida. Alguma forma dionisíaca, com certeza, não necessariamente à partir do uso de qualquer substância. Se o teatro é herdeiro de Eleusis, essa herança não se condiciona aos procedimentos arcaicos. Talvez o simples resgate, em grande escala, de uma consciência real da dimensão sagrada do teatro seja suficiente. Quando os artistas do Oficina falam das conquistas do grupo no sentido de perpetuar sua mensagem libertária, segurando seu espaço numa situação de disputa desleal com grandes forças do capital, dão uma pequena amostra da potência dessa arte quando praticada, de uma forma ou de outra, dentro da consciência e do respeito à sua origem sagrada. Outros artistas certamente desenvolvem esta consciência na prática teatral, e o ideal seria que todos os artistas o fizessem. E não só do teatro, também no trato de todas as linguagens derivadas da arte de contar histórias usando personagens. São artes sagradas, transformadoras. Tratadas como tal possivelmente dariam frutos muito mais libertadores. 


\section{REFERÊNCIAS}

ARAP, Fauzi. 1998. Mare Nostrum, sonhos, viagens e outros caminhos. São Paulo: SENAC

ARTAUD, Antonin. O Teatro e seu Duplo. Max Limonad, 1984.

BONDINHO. Organização Miguel Jost e Sérgio Cohn. - Rio de Janeiro: Beco do Azougue, 2008, p.294. Entrevistas.

BRANDÃO, Junito de Souza. Mitologia Grega. Vozes, 1986.

CAMPBELL, Joseph. O herói de mil faces. São Paulo: Cultrix, 1995.

CASSIRER, Ernst. Linguagem e mito. São Paulo: Perspectiva, 1985.

EDINGER, Edward. Anatomia da Psique. São Paulo. Cultrix, 1995.

ELIADE, Mircea. Mito e realidade. São Paulo: Perspectiva, 1978.

GUINSBURG, Jacob. O Romantismo. São Paulo. Perspectiva, 2005.

JOST, Miguel; COHN, Sérgio. Entrevistas Bondinho. Rio de Janeiro. Beco do Azougue, 2008.

JUNG, Carls Gustav. O Homem e seus Símbolos. Nova Fronteira, 1972.

JUNG, Carls Gustav. Sincronicidade. Vozes, 2000.

MICHALSKI, Yan. Reflexões sobre o teatro brasileiro no século XX. Rio de Janeiro: FUNARTE, 2005.

STAAL, Ana Helena Camargo de; CORRÊA, Zé Celso Martinez. Primeiro ato, cadernos, depoimentos, entrevistas (1958 - 1974), Editora 34, 1998.

TODOROV, Tzvetan. Introdução à literatura fantástica. São Paulo: Perspectiva, 1975.

VERNANT, Jean-Pierre. Mito e sociedade na Grécia antiga. Rio de Janeiro: José Olympio, 1992.

WASSON, R. Gordon, HOFFMAN, Albert, RUCK, Carl A. P. The Road to Eleusis - Unveiling the Secret of the Mysteries. North Atlantic Books, 2008. 